\title{
THE POLITICS OF SYMBOLISM
}

\section{IN THE MIXTEC CODICES}

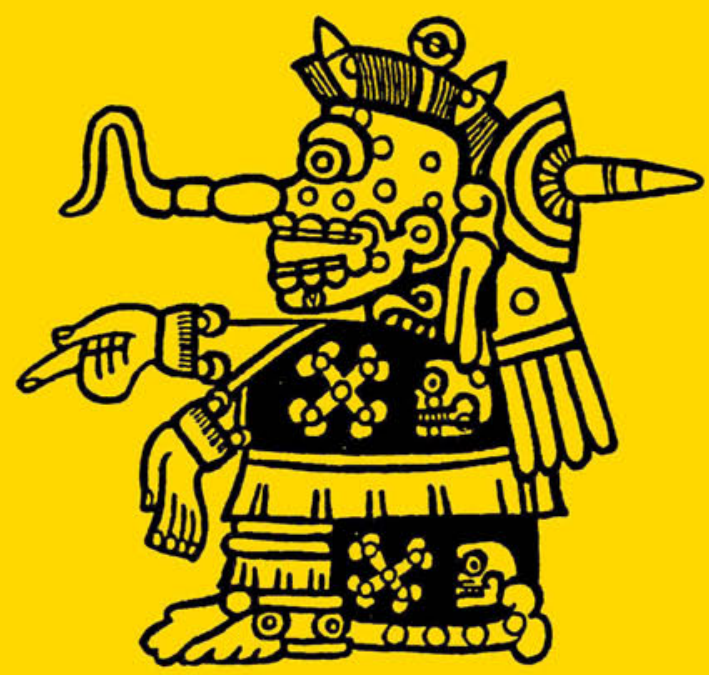

By
John M. D. Pohl

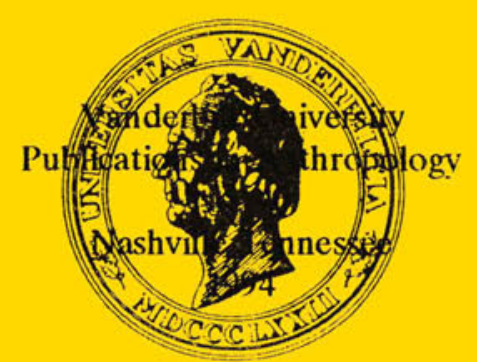




\title{
THE POLITICS OF SYMBOLISM
}

\section{IN THE MIXTEC CODICES}

\author{
By \\ John M. D. Pohl
}

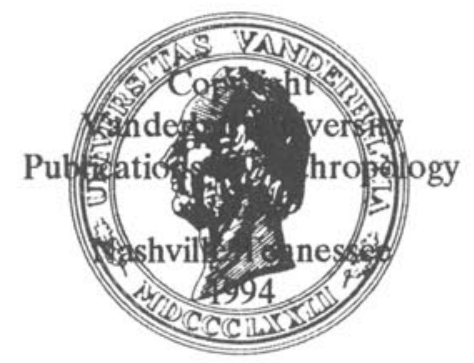




\section{VANDERBILT UNIVERSITY PUBLICATIONS IN ANTHROPOLOGY}

Vanderbilt University Publications in Anthropology are published by the Department of Anthropology, Vanderbilt University, Nashville Tennessee. This is a consecutively numbered series devoted to the dissemination of the results of scholarly research in the field of Anthropology but without specific restriction as to content or theoretical orientation of research, geographical concentration or institutional affiliation of the author.

John D. Monaghan, Editor

Ronald Spores, Founding Editor

William Fowler, Associate Editor

Mary S. Thieme, Managing Editor

Copyright 1994, Vanderbilt University

ISBN 935462-37-6 


\section{CONTENTS}

PREFACE

$\begin{array}{ll}\text { I. METHODS OF ANALYSIS } & 1\end{array}$

SUMMARY OF PAST RESEARCH

$\begin{array}{ll}\text { ELEMENTS OF MIXTEC KINGSHIP } & 10\end{array}$

AN ANALYTICAL METHODOLOGY OF POLITICS AND RITUAL 11

COSTUME AND REGALIA $\quad 14$

SUCCESSION AND THE REVELATION OF POLITICAL POWER 17

$\begin{array}{ll}\text { II. THE FOUR PRIESTS: POLITICAL STABILITY } & 19\end{array}$

SOCIAL STRATIFICATION AND ELITE KINSHIP 19

SACRED BUNDLES AND THE ÑUHU CULT 23

THE BUNDLE PRIESTS 31

CASE STUDIES $\quad 32$

III. THE YAHA YAHUI 42

THE YAHA YAHUI AS HECHIZERO 43

$\begin{array}{ll}\text { CASE STUDIES } & 47\end{array}$

SACRIFICE AND THE MANAGEMENT OF ECONOMY 51

"DOMINGO," "FRANCISCO," AND "JUAN" AS TITLES OF OFFICE 57

IV. 9 GRASS: THE ANCESTOR CULT 69

CASE STUDIES $\quad 70$

SKULL TEMPLE/SKULL PLACE $\quad 74$

LADY 9 GRASS AND FEMALE SKELETAL IMAGERY $\quad 77$

9 GRASS AS EARTH MOTHER GODDESS $\quad 79$

V 4 JAGUAR: THE FOREIGN BENEFACTOR 83

CASE STUDIES $\quad 86$

THE NOSE ORNAMENT CEREMONY $\quad 89$

COSTUME AND REGALIA 93

SAN MIGUEL TULANCINGO AS TULA 96

COIXTLAHUACA AND THE TOLTECA-CHICHIMECA 99

LORD 4 JAGUAR AND THE ORACULAR PRIESTS

OF CAMAXTLI-MIXCOATL IN COLONIAL TIMES 106 
VI. DISCUSSION, SUMMARY, AND CONCLUSIONS

FOOTNOTES

122

APPENDIX

128

BIBLIOGRAPHY

137 


\section{FIGURES}

1. (a) 3 Lizard, Zouche-Nuttall 13. (b) 8 Deer, Zouche-Nuttall 75.

(c) 3 Lizard as yahui, Zouche-Nuttall 44.

(d) 8 Deer as yahui, Zouche-Nuttall 50 .

2. Aztec Fire-Serpent Priest in Codex Borbonicus 33

3. A Piegan culture hero descends from heaven on a rope with the Ancient Pipe Bundle.

4. (a) The Blackfeet Sacred Beaver Bundle. (b) The Pawnee Evening Star Bundle with fire making implements.

(c) The Pawnee Skull Bundle surmounted by skull of first Pawnee man.

5. Sacred bundles in the Mixtec Codices.

6. The fuhu figure in Vindobonensis 22 and 27.

7. Greenstone effigy mask of dzahui in the collection of the Metropolitan Museum of Art.

8. Wooden fuhu effigy in the collection of the Museum für Völkerkunde, Vienna.

9. Stone $\curvearrowleft u h u$ heads from Yucunama, Mixteca Alta.

10. Four priests venerate the oracle 9 Grass (Vindobonensis 15-14).

11. Priest 5 Flower sheds blood from his ears (Zouche-Nuttall 15).

12. Priest 12 Wind descends from Place of Heaven on a rope ladder carrying a temple on his back.

13. Priest 5 Crocodile meets with three other members of the sacred council of four at Tilantongo (Zouche-Nuttall 25). 
14. Yahui wizard holding sacrificial knives flies into

or through a cliff (Zouche-Nuttall 19).

15. A yahui flies while clutching a human heart.

His cohort is the eagle or yaha.

16. Sacrificial knives.

17. The yaha-yahui or wizard 8 Wind emerges from a cave at Yucuñudahui.

18. Lord 8 Deer as yaha (Zouche-Nuttall 44).

19. Lord 4 Wind as yahui at the cave or cliff of the yahui (Codex Bodley 33V).

20. (a) Store house for chiles or yaha.

(b) Commoner bearing tribute (Códice de Yanhuitlan).

21. (a) The deity 7 Flower (Tonacatecuhtli to the Aztec), was patron of the thirteenth or highest heaven according to Codex Rios Vaticanus A. (b) The patron of ancestors, 7 Flower, holds hallucinogenic mushrooms (Vindobonensis 24). (c) 7 Flower portrayed as a personified ingot or gold jewel (Zouche-Nuttall).

(d) Oaxacan copper "money" shaped in the form of mushrooms.

22. Spanish friar using contemporary paintings to illustrate Christian bible stories for native noblemen (from Valades' Rhetorica Christiana).

23. (a) Saint Dominic de Guzmán bearing a church (from Tecali).

(b) Saint Dominic and Saint Francis embrace as "brothers" (after a painting by Fra Angelico).

24. Upon his death Saint Dominic is taken to heaven on a ladder by angels (after a medieval Tuscan painting).

25. (a) St. John riding the back of a fiery eagle from a 16th to 17th century carving at the church of Santo Domingo, Oaxaca.

(b) St. John and the serpent (after a painting by Piero di Cosimo). 
26. St. Dominic kneels before the crucified Christ. St. John stands to the right and the Virgin stands to the left (after a painting by Fra Angelico).

27. Schematization of political diversity of a Mixtec kingdom in the codices points to a tri-partite administrative system.

28. The tri-partite governmental scheme as symbolized in Zaachila Tomb 1.

29. The oracle Lady 9 Grass (Zouche-Nuttall 44).

30. The Temple of Lady 9 Grass (Vindobonensis 15).

31. (a) Death goddess (Fejervary-Mayer 28).

(b) Death goddess (Borgia 5).

32. 8 Deer receives the yacaxihuitl nose ornament, transforming him into a tecuhtli or lineage head (Bodley 9II).

33. 8 Deer venerates four priests carrying staffs and fans of merchantambassadors.

34. 4 Jaguar (Zouche-Nuttall 52).

35. A Chichimec lord is transformed into a tecuhtli by the Tlachiach of Cholula (Historia Tolteca-Chichimeca, Folio 21r).

36. The Cuauhtinchan maps portray routes taken by the first ToltecaChichimeca ancestors after their emergence from the caves of Chicomoztoc.

37. (a) Tetzcatlipoca (Cospi 86). (b) Camaxtli-Mixcoatl (Borgia 25).

(c) Tlahuizcalpantecuhtli (Vaticanus A).

38. (a) Place sign of Coixtlahuaca on the Lienzo de Tlapiltepec.

(b) Place Sign of San Miguel Tulancingo on the Lienzo de Tlapiltepec. 
39. (a) Man with Camaxtli-Mixcoatl face paint at the place sign of Coixtlahuaca (Bodley 34 IV). (b) Man with Camaxtli-Mixcoatl face paint at the place sign of San Miguel Tulancingo (Bodley 14 II).

40. 4 Jaguar seated before a compund place sign which includes the serpent qualifier for Coixtlahuaca and the cattail plant standing for San Miguel Tulancingo (Becker I 14).

41. 4 Jaguar (Lienzo de Tlapiltepec).

42. (a) The sacred bundle of Camaxtli-Mixcoatl attended by four priests in Sahagún's Primeros Memoriales. (b) Camxatli-Mixcoatl's son Xelhua in the Historia Tolteca-Chichimeca (Folio 3r).

43. The four Tolteca-Chichimeca priests of Camaxtli-Mixcoatl in the 101 Mapa de Cuauhtinchan 1.

44. The Codex Zouche-Nuttall obverse outlines the construction of an alliance corridor through the reckoning of genealogical connections between Tilantongo and Zaachila.

45. The employment of narrative history painted in the Mixteca-Puebla style was restricted to very specific forms of elite social behavior providing a symbolic context for feasting, gift exchange, and other forms of social and political intercourse carried out in palace courts.

46. (a) The oracle Lady 9 Grass awards Lord 4 Wind with two jewels shaped as an eagle and a jaguar. (b) Jewel from Tomb 7, Monte Alban shaped like an eagle. (c) Jewel shaped like an eagle belonging to Martin Ocelotl's treasure. 


\section{CHARTS}

1. Behavioral Characteristics of the Council of Priests

2. Behavioral Characteristics of the Yaha Yahui

3. Behavioral Characteristics of the Deity-Impersonator 9 Grass

72

4. Behavioral Characteristics of the Deity-Impersonator 4 Jaguar

88 


\section{MAPS}

1. Mexico showing the location of the Mixteca.

2. Principle Alliance corridors established by the middle of the

Postclassic (A.D. 1300) between factions of the Tolteca-

Chichimeca, the Mixtecs, and the Zapotecs.

3. Early Venta Salada (A.D. 700-1150) occupation of the Tehuacan

Valley (adapted from MacNeish et al. 1972).

4. Late Venta Salada (A.D. 1150-1521) occupation of the Tehuacan

Valley.

5. Las Flores (Late Classic A.D. 300-1000) occupation of the Nochixtlan 114 Valley (adapted from Spores 1972, Pohl and Byland 1990).

6. Natividad (Postclassic A.D. 1000-1521) occupation of the Nochixtlan 115 Valley.

7. Late Postclassic oracular shrines and associated priests in Puebla and Oaxaca. 


\section{PREFACE}

In deciphering the cartoon-like story panels, scholars have determined that the Mixtec codices were heroic histories and royal genealogies recorded by Oaxacan kings from the 10th century A.D. through the Conquest. The tales of marriage, wars, murders, and political intrigue would rival the works of Shakespeare or Aeschylus. Yet many questions are only now being resolved, not the least of which is why the story of Lord 8 Deer was so prominently featured. Despite the fact that his career focused on his 12th-century usurpation of the tiny kingdom of Tilantongo in the Mixteca Alta, there is considerable evidence that he was well known to 16th-century kings and queens throughout Oaxaca from Puebla to the Soconusco. Could his biography have served therefore as some kind of Iliad-like poetic epic? The answers are enabling codex scholars to restore a remarkable chapter in the PreColumbian history and literature of Mexico.

My interest in the 8 Deer saga and my subsequent Tilantongo archaeological project with Bruce Byland are the outgrowth of my fascination with finding ways to recreate the past through archaeology, theatre, and the cinema arts. Recognizing the codices as portable storyboards, like those used in film making, led me to believe that the books could tell us a great deal about an indigenous recreation of the past through oratory and dramatic performance.

The present study is derived from my 1984 dissertation. Eight years before I had read Alfonso Caso's commentary of Codex Bodley for the first time. Although I had satisfied myself that the codices were indeed the biographies of real kings, several questions continued to nag me. Who were the hundreds of other people that appear in the stories? What did they do? Where did they live? What was their relationship to the king, and why was their presence deemed so important that it was pictorialized in these holy books? In a film storyboard, each new character is carefully introduced so that we learn more about him or her as the narrative unfolds. In the Mixtec codices, people pop in and out of the narrative as though the reader is assumed to have some detailed knowledge of what roles these personages fulfilled. I propose that there are more than kings in the codices; these "mystery people" are legions of institutionalized governmental officials. Indeed, Ronald Spores and Barbro Dahlgren first noted Colonial references to these priestly councilors and administrators, people who by comparison rarely appear in such numbers in Aztec or even Maya elite art.

Political anthropologists emphasize that it is during times of stress, especially during the transition of power, that the full panorama of political activity will often reveal itself in traditional societies. For example, an examination of photographic portraits of African royal families during periods of stability often portray only the chief, his wives, and children. But during periods of tension photographs will include not only the chief and his immediate family but also priests, councilors, the queen mother, and any other political personnel deemed important to the maintenance of authority surrounding the paramount. The 8 Deer period in the codices is just such a time of social upheaval and it is characterized by the appearance of a host of kinsmen, military allies, and priests in the codices.

The basic methodology employed in this study owes much to the pioneering work of Eduard Seler. Seler very early on recognized that the key to deciphering the codices was through an analysis 
of costume and dress, the signifiers of actors playing different roles in the performance of drama. Many of these symbolic devices were described in detail by the Spaniards, who recognized the fundamental importance of communication through costume during the enactment of native religious ritual. The difference is that while Seler tended to focus on interpretations of deities, mythology, or celestial events, I have interpreted the material as a representation of political and social order, an interpretation that can be tested through comparison to ethnohistorical sources and even through the examination of the archeological remains where these events are thought to have taken place.

Although the picture writing of the codices is primarily representational, knowledge of the Mixtec language plays a critical role in decipherement. The language is tonal, which is to say that different meanings can be derived from the same words by changing the pronounciation. Linguists have found that nearly half the Mixtec vocabulary contains tone puns, and many of these are recognizable in the codices. Where meanings in various Mixtec dictionaries could point to such puns in the iconography, I have used them to support my case. Although linguistic hard-liners will take issue with this practice, I emphasize that I have only engaged in these interpretations when other lines of evidence seemed to warrant their ideological association.

I am indebted to many, many friends and colleagues who contributed their time and thoughts to discussions of my ideas. These include Patricia Anawalt, Carlos Arostegui, Ellen Baird, Elizabeth Boone, Betty Ann Brown, Bruce Byland, Carol Calloway, Wes Christensen, Christopher Donnan, Timothy Earle, Manuel Esparza, Jill Furst, Stephen Houston, Ernesto Gonzalez Licón, Maarten Jansen, Aurora Jansen, Kathryn Josserand, Crispín López Zarate, Wigberto Jiménez Moreno, Mark King, Cecelia Klein, Eduardo Matos Moctezuma, Dan McLaughlin, John Monaghan, Chris Moser, H.B. Nicholson, Mary Pohl, Ma. de los Ángeles Romero Frizzi, Emily Rabin, Nelly Robles, Linda Schele, Mary Elizabeth Smith, Ronald Spores, Karl Taube, Nancy P. Troike, Javier Urcid, Joseph Whitecotton, Judith Whitecotton and Marcus Winter. I thank the department of Pre-Columbian studies at Dumbarton Oaks for the opportunity to write and edit this volume as a 1990 Fellow, and the Fowler Museum of Cultural History for their institutional support as a research associate. This book is dedicated to the memory of Dr. and Mrs. John F. Pohl. 


\section{METHODS OF ANALYSIS}

When Paul Kirchhoff (1952) first proposed the term Mesoamerica, he defined it as a geographical area where the native inhabitants were united by a common history and possessed cultural traits which made them unique in the Americas. Among these traits Kirchhoff specifically noted hieroglyphic writings and ritual calendars which were employed to record divinatory and religious data, historical annals, tribute records, and maps. The Spaniards were especially interested in native books, and they employed scribes to continue the old pictorial traditions during the Colonial period, often adding Spanish or native language texts for explanation. By far the majority of such manuscripts, commonly called codices and lienzos, come from the Nahuatl-speaking regions in and around the Valley of Mexico. These have been the subject of considerable study since the Colonial period. Generations of scholars have gradually been able to identify many of the glyphic conventions, leading to a greater understanding of how this unique visual communication system functioned.

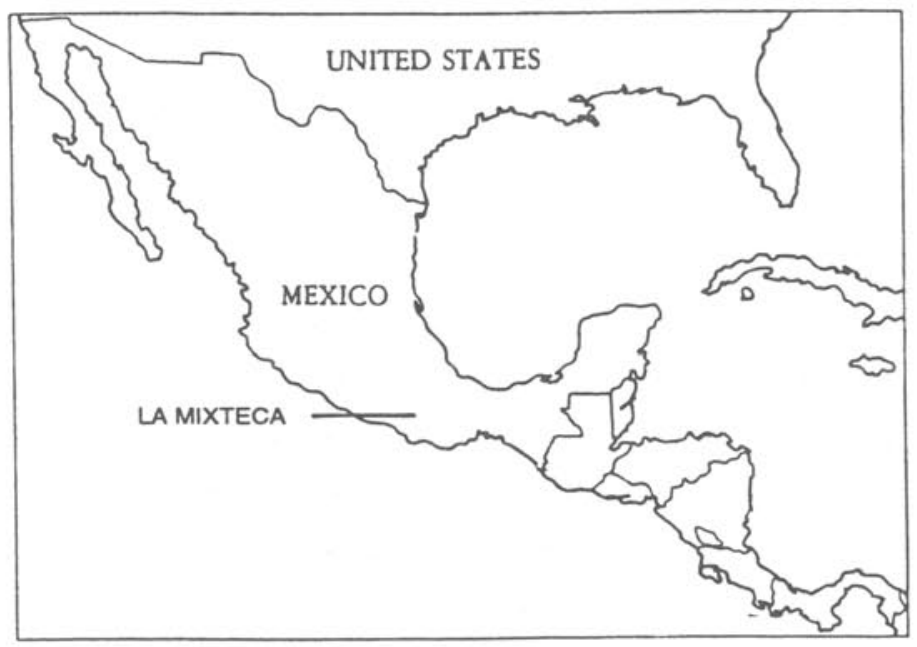

MAP 1: Mexico showing location of the Mixteca.

Codices and maps are well known from other areas of Mesoamerica as well. In many cases, the same graphic system has been employed, but the works are reflective of the differences in language and culture of the people who produced the work as well. An important corpus exists in the form of eight Pre-Conquest style codices attributed to the Mixtec speaking people of Oaxaca, Mexico (Map 1), collectively referred to as the Mixtec Codices. These are:

Codices Zouche-Nuttall and Egerton (British Museum, 2895, London)

Codices Bodley and Selden (Bodleian Library, Oxford). 
Codex Vindobonensis (National Bibliotek, Vienna)

Codex Colombino (Museo Nacional de Antropología, Mexico City).

Codices Becker I and II (Museum für Völkerkunde, Vienna).

The Mixtec codices were made of animal hide, covered with a gesso-like foundation upon which figures were painted. They were folded so that they could either be stored compactly or opened to reveal all of the pages on one side. The symbols represent persons, places, and things organized in such a manner as to communicate myths, histories, and genealogies. Scholars believe that the codices were made for (or by) the ancient Mixtec ruling class, because the pictorial style was continued into the Colonial period to document the affairs of that class' direct descendants, the newly transformed elite who had become the principal community leaders and land holders under the Spanish administration. By examining the codices as highly sacred objects revered as sources for both religious and political recounting, I intend to show how they documented the political ideology of a Mixtec elite class.

The artistic style of the pictorials has been called "Mixteca-Puebla." The term was proposed by George Vaillant (1962) to describe a "culture" which he viewed as residing in the modern states of Oaxaca and Puebla during the Postclassic period (A.D. 900-1521), and influencing the development of Aztec civilization. Although the Toltec tradition in the Northern Basin of Mexico during the early part of the same period (ca. A.D. 900-1200) is now regarded as the principal forerunner of the Aztec, "Mixteca-Puebla" is still an appropriate term for describing a unique artistic style that characterizes this period (Nicholson 1966, 1982).

In his analysis of the figures, H.B. Nicholson (1966:260) stated that the style is:

"Characterized by an almost geometric precision in delineation. Symbols are standardized and rarely so highly conventionalized that their original models cannot be ascertained. Colors are numerous and vivid, and play an important symbolic role in themselves. In general, there is much that is akin to modern caricature and cartooning of the Disney type with bold exaggeration of prominent features."

Donald Robertson (1970) went so far as to suggest that the Mixteca-Puebla style should be termed the "International Style" because its variants are found throughout Mesoamerica and executed in a wide variety of media, not only in codices but also polychrome pottery and wall murals. The explanation for the sudden adoption of so standardized a communication system, by cultures who previously had possessed very distinctive writing or pictorial styles during the Classic period (Teotihuacan, Xochicalco, Nuine, Monte Alban), is still a matter open to investigation. Exquisite Mixteca-Puebla polychrome vessels were found in Tomb 1 at Zaachila 
(Gallegos 1962, Paddock 1983). The tomb has been identified as that of the Zapotec lord 5 Flower in Codex Zouche-Nuttall 33, a Zaachila ruler who was alive in A.D. 1280 (Pohl and Byland n.d.a). Consequently, it seems that the style had reached its florescence in Oaxaca by at least that time.

The appearance of the Mixteca-Puebla style followed hard on the heels of dramatic changes in other components of material culture shared by societies living in both Puebla and Oaxaca. The Classic to Postclassic transition in the Mixteca-Alta (A.D. 900-1000) was characterized not only by major shifts in settlement pattern and the creation of a highly factionalized political universe, but also by the appearance of a new ceramic type, Yanhuitlan Red-on-Cream (Spores 1972, Byland n.d.). Yanhuitlan Red-on-Cream is a variant of Coyotlatelco Red-on-Cream/Buff, the hallmark of the Postclassic horizon from Cholula, through the Tehuacan Valley, to Coixtlahuaca (Rattray 1966, Noguera 1950, MacNeish et al 1970: 217, Bernal 1948).

Elizabeth Brumfiel (1989: 132-135) proposes that the appearance of such regional homogeneity in Postclassic ceramic styles was linked to sustained factional competition between city-states. Brumfiel argues that the success of larger than city-state political structures required coalition building through the amassing of loyal supporters and powerful allies in the face of competition by equals. This was achieved through mutual emulation and the development of shared political agendas (see also Renfrew 1986: 8).

"Because factions are not differentiated by their social programmes and because their competition focuses on the relative legitimacy of their claims, competing factions should not be differentiated stylistically. All competing factions should use the same symbolic vocabulary to state their claims of legitimacy. Archaeologically, regions drawn into factional competition should produce symbolic artifacts in a single regional style. Factions try to make themselves appear better not different."

(Brumfiel 1989: 132).

The Mapas de Cuauhtinchan (Bittman Simons 1968, Yoneda 1981), the lienzos of the Coixtlahuaca group (Caso 1961b, Parmenter 1982), and the Mixtec codices in fact provide documentary evidence for factional alliance corridors in the early Postclassic, corridors which united Puebla and Oaxaca, the area in which Coyotatelco is recognized as the primary early Postclassic diagnostic (Map 2). These confederations were formed through elite intermarriage, with membership often determined through claims of divine descent or reckoned through one of several heroic cosmogonies. Factions thereby even defined new forms of ethnicity (at least at the aristocratic level) that superseded cultural distinctions otherwise maintained by Nahuatl, Popolocan, Chocho, Mazatec, Cuicatec, Mixtec, and Zapotec speaking peoples (Byland and Pohl: n.d., in press, Kirchhoff et al: 1976, Reyes 1977, Jansen 1989, Davies 1980). 
TENOCHTITLAN •

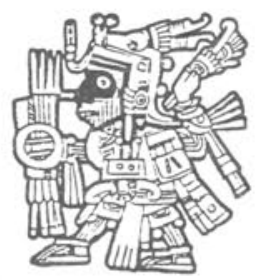

CAMAXTLI-MIXCOATL

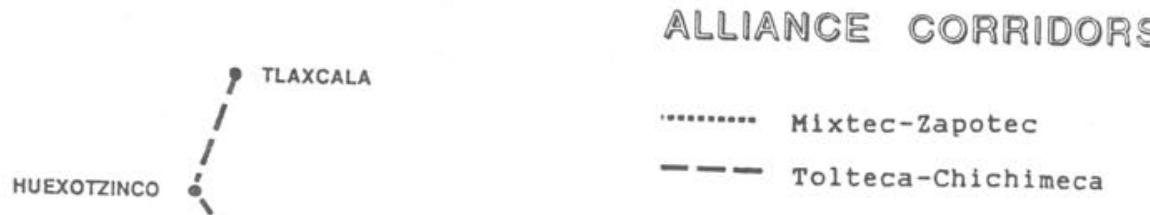

ALLIANCE CORRIDORS

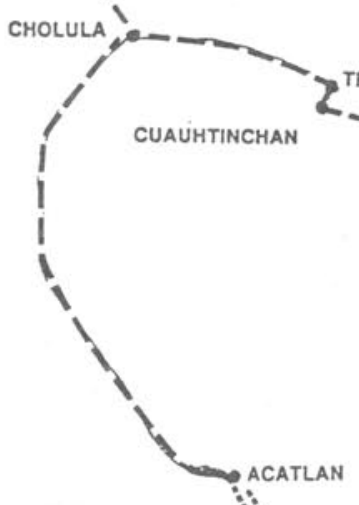

TEPEYACAC

tecamachalco

1

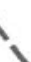

1

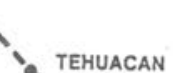

$\therefore$

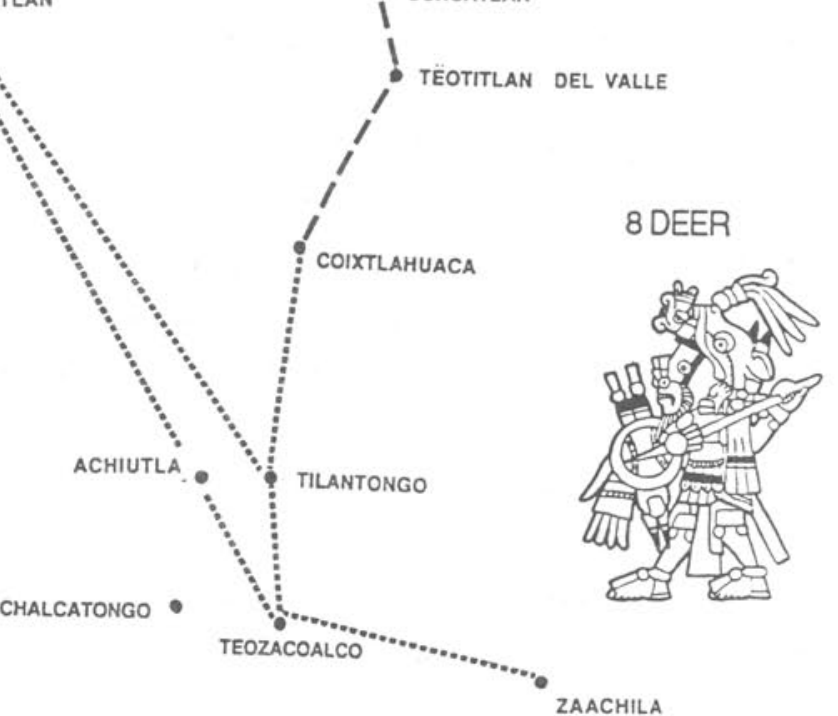

MAP 2: Principle alliance corridors established by the middle of the Postclassic (A.D. 1300) between factions of the Tolteca-Chichimeca, the Mixtecs, and the Zapotecs. Reconstruction based on various ethnohistorical sources including the Mapas de Cuauhtinchan, the Historia Tolteca Chichimeca, and the Mixtec Codices. Factional confederations cross-cut ethnicity defined by language groups including Nahuatl, Popolocan, Mazatec, Chocho, Mixtec, and Zapotec. 
It is significant, therefore, that the Mixteca-Puebla Style is not linguistically based in the same way as Maya or Zapotec hieroglyphic writing had been, but rather it is a highly developed system of cartooning, a form of visual communication which can be remarkably effective in facilitating information exchange especially at the international level. Nowhere is this more evident than in our own contemporary revolution in international communication through the development of symbolism in film, television, computer language, and advertising.

\section{SUMMARY OF PAST RESEARCH}

Although none of the Mixtec codices has ever belonged to an excavated archaeological complex, several were transported to Europe directly after the Conquest as items of curiosity. They have had a colorful history, but in many cases information concerning their location had been lacking until the middle of the nineteenth century (see Troike, n.d.a.).

Mixtec codices first captured the eye of the pioneer scholar Eduard Seler at the turn of the century, when he was working on his extensive examination of Preconquest style manuscripts in general. Since he had no reason to believe otherwise, Seler identified them as Aztec and proposed highly ritualistic and religious interpretations for the pictorial scenes, emphasizing astronomical counts, world directional symbolism, and color symbolism (Seler 1960). Although this approach continued to be advocated by other German scholars like Walter Lehmann and Ottokar Smital (1929) in their study of the Codex Vindobonensis, it was Zelia Nuttall (1902) who laid the foundation for a more fruitful line of research with the Peabody publication of the Codex Zouche-Nuttall, a manuscript originally belonging to the English Lord Zouche. Nuttall proposed that the codex related the activities of historical persons. She was able to substantiate her claims by noting that figures who were accompanied by specific calendrical signs also had specific costume attributes and seemed to be associated with particular dates and place signs. She wrote the first commentary on an important Mixtec lord who had the calendrical sign 8 Deer (See Appendix for discussion of the naming system).

Following this breakthrough, other scholars began to identify the same persons and events in other pictorials, leading to the definition of a Mixtec group of codices separate from that now termed the Borgia group, a corpus of manuscripts believed to be mainly ritual and divinatory in content and not necessarily of Mixtec origin. James Cooper Clark (1912) identified 8 Deer in the Codex Colombino by first identifying his personal name, "Jaguar Claw," and then by making associations between scenes in the Colombino and those identified by Zelia Nuttall in the Codex Zouche-Nuttall. Herbert Spinden (1935) wrote the first comprehensive article on the eight major manuscripts and thus defined the Mixtec group. He summarized the basic format and the major pictographic devices, while at the same time discussing specific problems, such as the question of whether some personages were men or gods (Spinden 1935: 431) (1). Finally, he identified an important contemporary of Lord 8 Deer: Lady 6 Monkey. 
Spinden's analysis laid the groundwork for the more comprehensive studies made by Alfonso Caso and those who have succeeded him.

Alfonso Caso was the first to establish Mixtec manuscript studies as a special field in Mesoamerican research. He was stimulated by his discovery of artifacts buried in Tomb 7 of Monte Alban that were iconographically and stylistically related to the codices (Caso 1969). He embarked on an intensive study of not only the eight major manuscripts, but numerous Postconquest lienzos and maps as well. To date, an unparalleled breakthrough in Mixtec studies remains Caso's (1949) article on the 1580 map that accompanied the Relación Geográfica of Teozacoalco, a town in the Mixteca Alta. The map shows a long genealogy of the rulers of not only Teozacoalco but Tilantongo. Among the first of these rulers are Lord 5 Movement, Lord 2 Rain, and the great Lord 8 Deer himself. The location of the important events in the Mixtec pictorials could be identified with certainty as Oaxaca. (2)

Following the Teozacoalco map, Caso published over twenty important articles and books related to the codices. Most notable among these are his commentaries on the codices Bodley (Caso 1960), Selden (Caso 1964), and Colombino (Caso 1966), in addition to the posthumous publication in two volumes of Reyes y Reinos de la Mixteca (Caso 1977, 1979). While the Teozacoalco map enabled Caso to establish a tentative chronology, including the equivalent Christian year dates for four successive dynasties at Tilantongo and two at Teozacoalco, his analysis of the Codex Bodley permitted him to trace the activities of contemporary individuals whose interactions were described only in part in the various other manuscripts. (3) This permitted him to hypothesize the political motivation for the behavior of personages like Lord 8 Deer, Lady 6 Monkey, and Lord 4 Wind and to fuse the sometimes contradictory details told in each pictorial into one comprehensible story. The problem of whether Mixtec codices concerned strictly religious or secular affairs had been settled, and their unique historical nature had been confirmed. Individuals had been identified and important events involving those personages had been dated. However, any study of the past concerns not only the behavior of ancient peoples in time but in space as well.

Mary Elizabeth Smith, an art historian, has analyzed the place signs in the codices. She began with an analysis of the Codex Colombino, which she attributed to the south coast of Oaxaca, and suggested that 8 Deer spent much of his early life there (Smith 1963). In making her identification, Smith relied heavily not only on Postconquest documents, but on extensive field research. She recorded many of the names for present-day towns and archaeological sites still known in the Mixtec language today. Smith's book, Picture Writing from Ancient Southern Mexico: Mixtec Place Signs and Maps, stands as the ground-breaking treatise on place sign decipherment (Smith 1973a).

Place sign studies have a particularly important application to archaeological research. Archaeologists tend to examine the behavior of groups of people through time rather than the behavior of individual persons in any single time period. Such persons, whether historically known or unknown, tend to be invisible in the archaeological record. This is particularly true of cultures "broken" by outside incursions and altered by enculturation. In 
emphasizing a study of place signs, Smith has not only been able to identify the location of the activities of successive rulers (the group) but coincidently to identify patterns of interaction between those rulers' territories.

We know that the persons depicted in the manuscripts are members of extended Mixtec royal lineages ["linajes" in Burgoa's terminology (1934)] who maintained preferred marriage patterns between their territories through time (4). Evidence for marriage patterns allows an archaeologist to presume that certain sites might display some sort of shared artifactual similarity, particularly in ceramic style. Consequently, studies of interaction patterns involving place signs, together with archaeological studies of artifactual relationships between sites, can be used to reconstruct social interaction from two distinct anthropological views (See Pohl and Byland 1990). (5)

Smith's (1983a) identification of Codex Selden as a manuscript from a town in the Nochixtlan Valley of the Mixteca Alta is a good case in point. Smith compared the glyph for "Belching Mountain" found in Codices Bodley and Selden with Colonial and modern names for the town of Magdalena Jaltepec, and found she was able to pinpoint the activities of Lady 6 Monkey, Lord 8 Deer's contemporary. Jaltepec is a modern community that lies adjacent to Tilantongo. It is precisely this kind of relationship which can be tested archaeologically (Byland and Pohl in press).

During the mid-1970's, there was a flurry of interest in Mixtec pictorials in the wake of tremendous advances in Mesoamerican archaeology in general (4). Although much of the work dealt with redefining Alfonso Caso's chronology and with a reinterpretation of principal events, new areas of interest have blossomed. Nicholson (1967:258) first pointed out some of the chronology's shortcomings. When Caso encountered ambiguities in his data, he always chose one of several possible interpretations for various activities without expressing his reasons for doing so, other than that it seemed to fit into his chronology. The chronology, however, was his weakest point, for he often assumed that the persons depicted were involved in activities chronologically aligned page after page.

Emily Rabin (n.d.a., n.d.b.) noted that Caso failed to cross-check his dates between intermarrying family lines as listed in not only Codex Bodley, but all of the manuscripts. As a result, she proposed that in at least one instance, Caso's Christian dates were in error by at least three fifty-two year cycles. (Rabin n.d.a.:2) (5). Of greatest concern to the present study is Caso's chronological placement of Lord 5 Crocodile, 8 Deer's father. Caso (1960:33-36) proposed that 5 Crocodile began the second dynasty of Tilantongo following the mysterious death of Lord 2 Rain, even though he is never shown seated on the Tilantongo place sign. However Rabin was able to set the period of 5 Crocodile's life back in time to the first dynasty of Tilantongo by correlating the Bodley $6 \mathrm{~V}$ scene of an important marriage between the Jaltepec Lady 9 Wind and the Tilantongo Lord 10 Eagle with a cognate in Selden 5IV. These latter rulers were the parents of Lady 6 Monkey, the famous contemporary of 8 Deer (See Appendix).

Apparently the break in Codex Bodley $6 \mathrm{I}$ implies that the 5 Crocodile story should be 
viewed, to use a cinematic term, as a "flashback." Naturally, the implications of Rabin's proposal are quite important because it is apparent that not all the personages who display genealogical backgrounds in the codices are necessarily royal paramounts. Those, such as Lord 5 Crocodile, who were contemporaneous with the first dynasty of Tilantongo probably filled some other function in the hierarchy, such as priests or regents who affected royal authority. In one respect, Rabin's research has created more questions than it has answered, but in another respect it has opened up an expanded area of possibilities for interpretation (see Appendix for a description of the Mixtec dating system with an illustration of a section of Rabin's revised chronology).

While making a study of the Codices Colombino and Becker, Nancy Troike also became aware of the problem with Caso's chronology. Although she intended at first to study the 8 Deer story in the Codex Zouche-Nuttall, Troike (n.d.b.) realized that the cognate sections in the Colombino-Becker were in fact more comprehensible as a narrative, even though the manuscript had sustained considerable damage (6). Following her careful reconstruction of the original page order of the Colombino-Becker, thereby reconstructing the proper sequence of scenes, Troike made a detailed analysis of the text and extrapolated a story line that included all possible interpretations. Troike was able to add several significant details to the 8 Deer story and presented a theory that Mixtec pictorial artists were concerned only with those events that concerned Lord 8 Deer's rise to power as founder of the second dynasty of Tilantongo, and not with his overall activities in general.

This revelation, together with the possibility that the lives of both 8 Deer and his father overlapped the lives of the last rulers of Tilantongo's first dynasty, has provided us with a new perspective on Mixtec codical history. Troike has also noted the cyclical behavioral pattern characterized by acts of violence and death which are then followed by a rearrangement of the marriage pattern. The emphasis of these histories, even in personalized accounts like that of 8 Deer, is therefore not on royal individuals; but on significant events in a developmental history by which Mixtec nobility reckoned competitive alliance corridors that ran throughout central Oaxaca.

Rabin's revised chronology has also led to a reconsideration of the Codex Vindobonensis Obverse. This codex has been of special interest for it is the only member of the Mixtec group that has been termed mythical or religious and not strictly historical. Consequently, many of the personages portrayed in the manuscript have been thought to be deities for a number of reasons. First, several wear costume and regalia which are traditionally associated with members of the greater Mesoamerican Postclassic pantheon (see Spranz 1973). Prominent among these are apparent Mixtec variants of the gods Cihuacoatl, Ehecatl-Quetzalcoatl, Tonatiuh, Xochipilli, Tlazolteotl, and Xipe Totec. The distinguishing characteristic is that in Codex Vindobonensis each has a calendrical name and they are involved in a series of acts that may be viewed as supernatural.

Vindobonensis 48, for instance, shows 9 Wind "Ehecatl-Quetzalcoatl" descending from 
the sky on a rope, and page 37 shows the miraculous birth of a man from a tree. In some cases, particular scenes can be compared directly. with those in manuscripts from the Borgia group. (7) Vindobonensis 47 shows 9 Wind lifting the "sky" in much the same Atlantean fashion as his counterpart in Borgia 51 (see Garibay 1979: Historia de los Mexicanos por sus Pinturas, for reference to a comparable Aztec myth). Finally, many of the same personages who appear in the Vindobonensis affect the historical lives of individuals in the other pictorials, even though to do so, they would seemingly have had to have lifespans ranging over one hundred years (Lady 9 Grass, the Cihuacoatl variant discussed in Chapter IV, is a good example).

Jill Furst (1978a) has published a detailed commentary on the Vindobonensis obverse in which she interpreted the principal figures and dates as being mainly mythological. To Furst, these personages are the deities of a Mixtec pantheon, and the rituals in which they participate involve the creation of the world and the establishment of the first kingdoms. One of the principal creator gods was 9 Wind. Nicholson (1978) proposed that this deity was a Mixtec equivalent of the Central Mexican "Ehecatl-Quetzalcoatl." Indeed, the same calendrical name is sometimes associated with this god in Central Mexico (Caso 1961a: 81), and many times the Mixtec 9 Wind is shown wearing the red "snouted" buccal mask, his most common diagnostic in Central Mexican art. Although Furst (1978a: 6) hesitates to equate the two Mesoamerican conceptions, she does agree with Nicholson that 9 Wind was the divine culture hero of the Mixtec.

Furst also proposes that not only were certain persons and places mythical, but dates were as well. She found several unusual correlations between places and dates. On Vindobonensis 42 the year 1 Rabbit/ day 1 Rabbit is frequently associated with the place "Mountain That Opens Up/Insect," (or Mountain that Opens Up/Hill of the Wasp), even though the listing of the date does not always fit into the chronological scheme in which the place sign is placed. Another example is the year 1 Reed, day 1 Crocodile, which Furst believes is a metaphorical sign for "beginning" (Furst 1978a: 91).

Maarten Jansen (1982a), on the other hand, proposes that the Vindobonensis obverse is much more factual than has been previously thought. Indeed, Rabin's shortening of the chronology places many of the Mixtec "deities" close to, if not actually within, the 52-year cycles which involve 5 Crocodile and 8 Deer. This implies that they possessed some degree of mortality. Although he does not argue against the pronounced ritual-mythological nature of the Vindobonensis, Jansen (1982a: 22) associated the place designated as "Heaven" with the name of an actual mountain overlooking the Valley of Apoala, the site where the first ancestors were reputed to be born from trees (Reyes 1976: I). Bruce Byland and I have proposed that a second Place of Heaven may lie in the Valley of Achiutla (Byland and Pohl: in press, Castellanos 1910).

In this brief review of the progress made in Mixtec codical studies from the first commentaries by Nuttall through Caso's interpretations and those of his successors, it has been established that the persons, places, and events portrayed can be deemed historical and therefore understandable to us as documents of social behavior among an ancient Mexican ruling 
class. If we are discussing elite social behavior, however, are we not also discussing political behavior, that is, "political" in its elementary sense as any social interaction or public affair outside the nuclear family or domestic area? If we begin to discuss Mixtec pictorials in a political sense, we must concurrently be referring to some sort of governmental system. The question is, what kind?

\section{ELEMENTS OF MIXTEC KINGSHIP}

Few would argue that the Mixtec did not have a stratified political structure with a significant division between an elite class and a peasant population (Dahlgren 1954: 167-183, Spores 1967,1983$)$. Whether it could be considered technically a stratified society or a state society (Fried 1960, 1967) is still debatable, for the emphasis on kinship so evident in the codices is more characteristic of ranked societies like chiefdoms, where kinship is the principal means of defining social position. The paramount is an individual born from a"preferred" lineage, often being the most direct living descendant of the group's founding ancestor (Service 1962). The Postclassic Mixtec we study from ethnohistorical sources did not develop as a society under pristine conditions but rather as a secondary state, possibly by conquest on the part of an outside group, but more likely by the emulation of an outside group, particularly the Tolteca-Chichimeca confederations of Puebla (Byland n.d.). (8)

The problem with states formed by such processes, however, is that they can possess an amalgamation of attributes derived from any of the principal social categories commonly used by anthropologists to describe several levels of social development (See Johnson and Earle 1987:246-270). For instance, the Mixtec elite class was clearly preoccupied with lineage and kinship relations for determining rank, even though they employed some of the mechanisms of sophisticated state-society governments. There is also evidence for the institutionalization of non-kin based power groups in the oracular priests of Chalcatongo, Achiutla, and Mitla, whom the Spaniards described as being like Late Renaissance archbishops and popes (See Chapter IV).

The Relaciones Geográficas (Paso y Troncoso 1905) have been the focus of Ronald Spores' (1974, 1983) more detailed ethnohistoric research on the Mixtec. Spores proposes that:

1. The Mixtec were organized into two major social strata headed by a ruling class from which individuals could claim the paramount position only through hereditary eligibility.

2. The ruling class was comprised of royal kinship groups that were ranked.

3. The Mixteca was divided into "kingdoms" and ruled by a plurality of sovereigns who 
for the most part viewed themselves as equals.

The Mixtec aristocracy employed full-time priests who served as royal administrators. These individuals or special groups are consistently referred to throughout various relaciones (see Paso y Troncoso 1905: 74, Acuña 1984) and inquisitions, where they are often called not only "sacerdotes," but also "regidores" and "gobernadores." It will become clear in this study that a political system administered by priests is not at all inconsistent with societies in which class is determined by one's membership in, or proximity to, a royal kin group. Such groups are often ranked according to their relation to the bloodline of a common founding ancestor. The ancestor is often viewed as divine, and those who are deemed closest to him in blood are therefore most eligible to succeed to the throne. Following their succession to rulership, they too are considered holy.

The confirmation of divinity therefore becomes the ideological pillar upon which the lord's right to rulership is supported. The Mixtec concept of divine rulership is embodied in a title reserved solely for the ruling class: yya tnuhu (Spores 1983: 228). Among several significant entries in the Arana-Swadesh dictionary for yya (or iya) are both "noble" and "deity". (9) A governmental system like that of the Mixtec would have had to select their administrators from the priesthood, for the ruler had become simultaneously both head of state and the focus of the popular religion.

In retrospect, Furst (1978a) and Jansen (1982a) are simply discussing two sides of a single concept in their studies of Codex Vindobonensis. Neither disagrees that the obverse documents the original division of the lands and the establishment of the first ancestral rulers. Furst, however, is emphasizing the heroic, mythological, and religious aspect of a genesis story, while Jansen is emphasizing the worldly. The two approaches taken together can be termed an "historical religion." Since the Mixtec confirmed their rulers with a sense of divinity, the source of that divinity would naturally have been rooted in various forms of miraculous behavior on the part of the first royal ancestors in the remote past. The fact that the original Mixtec kings were born from trees is a good example of an ancestral miracle (Burgoa 1934 I:274, [García] Seler 1904a: 289).

\section{AN ANALYTICAL METHODOLOGY OF POLITICS AND RITUAL}

Any interdisciplinary approach to the past has only proven effective as long as investigators are able to ask the same questions of the varying data sets. Unfortunately, the nature of one set may not lend itself to the same scrutiny as another set. In the past, archaeologists, ethnohistorians, and art historians have tended to tailor their interests according to the composition of their data. The archaeologist might be interested in ceramics for the development of a chronology, while the ethnohistorian might be interested in social 
structure and the art historian in religion. Such varying approaches taken separately, however, only reflect aspects of cultural complexity without solving a joint problem.

The growing sophistication of analytical techniques in studying so unique a corpus of pictorial data as Mixtec codices, however, permits specialists to apply their knowledge to solving problems which the three sub-disciplines of Precolumbian studies have often been unable to do alone. In short, the codices should be treated as political documents, but political in the sense of the reality of the Mixtec system: government by a plurality of rulers who communicated their doctrine through symbolism and ceremony. Ceremonialism pervades all of the activities portrayed in the Mixtec pictorials. Captives are ritually sacrificed, marriage ceremonies are distinguished by ritual bathing and dancing, peregrinations are made to sacred places and deities consulted, but most important to this study, the most prominent personages are always displayed in elaborate costume and regalia which qualify their behavior. Abner Cohen, writing on politics, symbolism, and ceremony, has stated:

"The organization of authority is a difficult problem faced in all societies, simple and industrial, and by groupings formal and informal... All social order involves hierarchy and all hierarchy involves relations between superiors, inferiors, and equals, and the mobility between these statuses. In both simple and industrial societies this is achieved by ceremonials. In most political groups, positions of authority are staffed by mortal people like you and me and it is a perpetual problem in society to elevate ordinary individuals to positions of 'semi-gods'. All the intellect, skill, and cunning of the ideologist, the politician, the theologian, and the artist and all the techniques of color, music, poetry, and drama are needed to create, accomplish and perpetuate the myth of authority in the face of continually subversive processes of different sorts." (Cohen 1976:78)

Cohen's observations seem to coincide with those of E.R. Leach's approach to religious ceremonials and rituals. Namely, ceremonial activities are representative of group solidarity (both real and fictive) and serve to reinforce social relations through public display. However, it must be understood that this solidarity is demonstrated only at the moment at which the ritual takes place (Leach 1965 : 281). I.J. Gelb (1963:3) suggests that such activity has two major drawbacks, especially for societies that lack written documentation. First, it has momentary value and is thus restricted as to time; as soon as the dance is performed, the words uttered, and the gestures made, all is gone and cannot be revived except by repetition; and second, they can be used only in communication between persons more or less in proximity to each other and are therefore restricted as to space. Since a ceremony is temporary, the continuation of solidarity and the demonstration of social order inherent in that ceremony are also temporary (Leach 1965: 281).

The differences between the enactment of ceremony and the production of painted histories may not have been entirely distinct. The performance of historical drama is noted by 
Burgoa (1934 I: 396) for the Mixtec. He states, for instance, that the festival of Santiago still held annually in Cuilapan, was actually derived from a Preconquest festival reenacting the defeat of a Zapotec lord of Zaachila. It is probable that the codices were not meant to be simply "read" but actually performed as well. We know that the codices were hung on palace walls and that royal histories were recited from the books much like the presentation of a story-board (Byland and Pohl in press).

Mark King (n.d.) has suggested that the codices were "sung", noting that the word for a singer in the 16th century Alvarado dictionary is tutuyondaayaa or "one who holds the song book." John Monaghan (1990a) has gone even further by proposing a hypothetical reconstruction of the poetics of recitation in Codex Vindobonensis. Miguel León Portilla (1969, 1970) has examined the performance of historical drama as a kind of "literary symposium" characteristic of high level political gatherings between Postclassic Mexican noblemen. Lords and priests donned costumes and enacted specific roles, while singing to musical accompaniment. Herrera (1945: 170) noted that Mixtec lords even wore garments with paintings of the "history of their gods," probably emulating the codices from which they recited. Clay stamps used to imprint patterns on such clothing have survived (Karst 1972). One example even depicts Lord 8 Deer meeting with his Tolteca-Chichimeca, ally Lord 4 Jaguar (Enciso 1953: 126, Fig. 1). The assemblies of lords also included feasting and drinking with polychrome vessels decorated with historical narratives found in the codical texts. An outstanding example is the tripod "Nochixtlan Vase" in the Mexican National Museum of History and Anthropology which portrays scenes cognate to Zouche-Nuttall 15-19. (Byland and Pohl in press).

The fact that the Mixtec wanted to "fix" important elements of ceremonial life by painting manuscripts implies that they had a need to document for future reference a ritual continuation of solidarity and the demonstration of social order imbedded in history. Indeed, the codices effectively solve the problems with ceremonies described above, for they convey the essential ideas with the correct symbolic context without being limited by time and space. One may argue, therefore, that a social system managed by factionalized elites, trying to expand their territory and elevate their lineage status by arguing descent, would find great advantage in painting and preserving their own accounts of the society's ritual-political history. (10)

It is noteworthy that communication through either ritual performance or pictorial narrative are equally dependent upon the symbolism inherent in costume and regalia born by the principals in the story, the persistence of which is nowhere more evident than in folk dress and ritual dance costumes worn throughout Oaxaca today (Cordry and Cordry 1968, Cordry 1980, Brown 1988). (11) Since we no longer possess original poetic recitations for the codices, we can only rely on a reconstruction of the events through chronological guides and an analysis of ritual imbedded in the symbology of costume, headdress, regalia, and facial ornamentation. 


\section{COSTUME AND REGALIA}

The use of symbols inherent in costume and regalia for interpreting caricatures of gods, royalty, priests, and other personages in the Precolumbian style manuscripts is, of course, not new to Mesoamerican studies. The Spaniards clearly perceived that the symbolism of ornamentation was of fundamental importance to understanding Precolumbian religious and political ideology, both in painted manuscripts and in real life. Book 10 of the Florentine Codex, Codex Vaticanus A, and Codex Tudela all contain descriptions of ritual dress as symbolic of ethnicity. Codices Magliabechiano and Tudela present a catalog of forty-five mantle designs that were to be worn only during certain religious ceremonies or awarded as royal gifts (Boone 1983: 168-177). The Codex Mendoza prescribes specific forms of costume for various ranks of soldiers in the army of the Triple Alliance (Pohl 1991). Sumptuary laws were strictly enforced in Mesoamerica, causing dress to become the primary means for the display of power, prestige, and social status, especially on ritual occasions (Anawalt 1981, 1990). Dressing to impersonate certain gods was a widespread practice. Sacrificial victims were commonly arrayed in the garb of the deities to whom they were dedicated. High government officials dressed in the regalia of gods on many ceremonial occasions as well. The Cihuacoatl priest, for example, dressed as the goddess for whom his office was named (Durán 1964:230).

Throughout Codex Telleriano Remensis and Vaticanus A, deities are not only described for their supernatural properties, but detailed descriptions are given of costume attributes, as though the dress was considered to be a significant part of the god's persona. Costume and regalia are even invoked in prayers to the gods (Sahagún 1950-1982); Cihuacoatl: "The eagle.., with serpent blood painted, with eagle plumes crowned"; Xochipilli: "the god of the thigh skin face paint."

The work of Eduard Seler in interpreting Codex Borgia was founded on his comparative analysis of the representations of Aztec deities glossed with Spanish notations in the Primeros Memoriales of Sahagún (see Baird n.d.), the Codex Telleriano Remensis, Codex Vaticanus A, and Codex Maglibecchiano. Other scholars, like Nicholson (1971a), have employed costume analysis most effectively in discussing the nature of the Aztec pantheon, and Bodo Spranz (1973) has broken down the distinctive costume and regalia in the Borgia group thereby constructing a dictionary of codical symbolism.

Richard Townsend (1979) has presented a provocative analysis of ritual attire as a visual metaphoric language; Patricia Anawalt (1981) has written a comprehensive study of costume as depicted in the codices emphasizing the ethnic characteristics of dress; and Cecilia F. Klein $(1984,1988)$ has discussed costume as an indicator of rank, status, and office in the Aztec state. The great number and variety of costumes worn by various personages are also outstanding features of Mixtec codices. Elsewhere, I have proposed that the costume qualifies a specific set of body poses in much the same way as glyphic elements qualify a specific set of substantives on place signs (Pohl n.d.a.: 15-16). The costume is the key to understanding the context of the activity reflected in pose. 

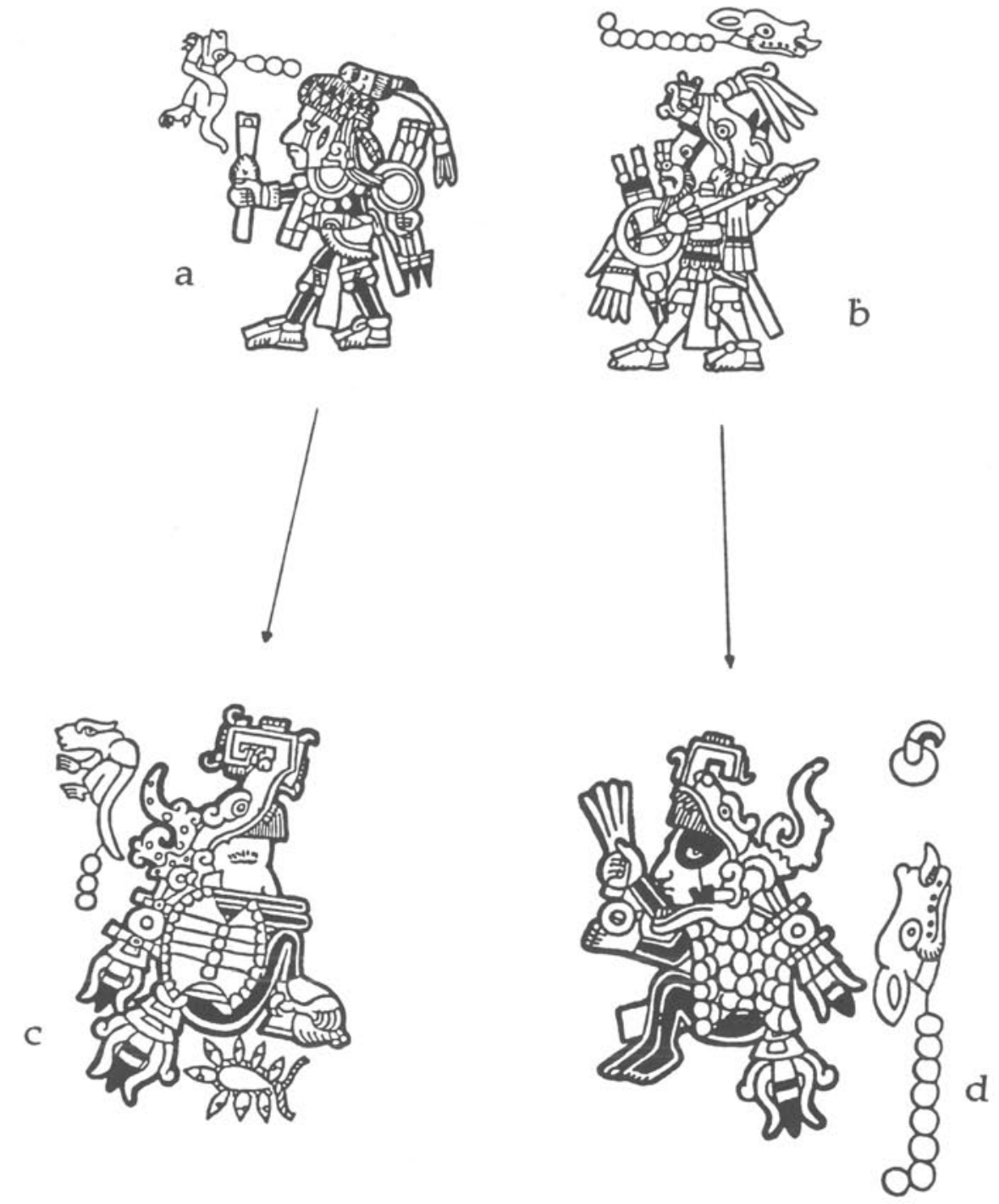

Figure 1: (a) 3 Lizard, Zouche-Nuttall 13. (b) 8 Deer, Zouche-Nuttall 75. (c) 3 Lizard as yahui, Zouche-Nuttall 44. (d) 8 Deer as yahui, Zouche-Nuttall 50.

On page 75 of the Zouche-Nuttall, for instance, three personages are shown displaying the pose for "hostility" (see Troike 1982:199-201). The central figure, recognizable as 8 Deer, is shown with shield, atlatl darts, and a lance, together with a jaguar helmet (Fig. 1a). As one might suspect, this costume set is peculiar to his military activities. In contrast, ZoucheNuttall page 82 shows 8 Deer attending the funeral of his half-brother 12 Movement. Here, he is wearing a cape, gold diadem, and feather hair ornament. Both clothing sets are unique to 8 Deer in the Zouche-Nuttall. 


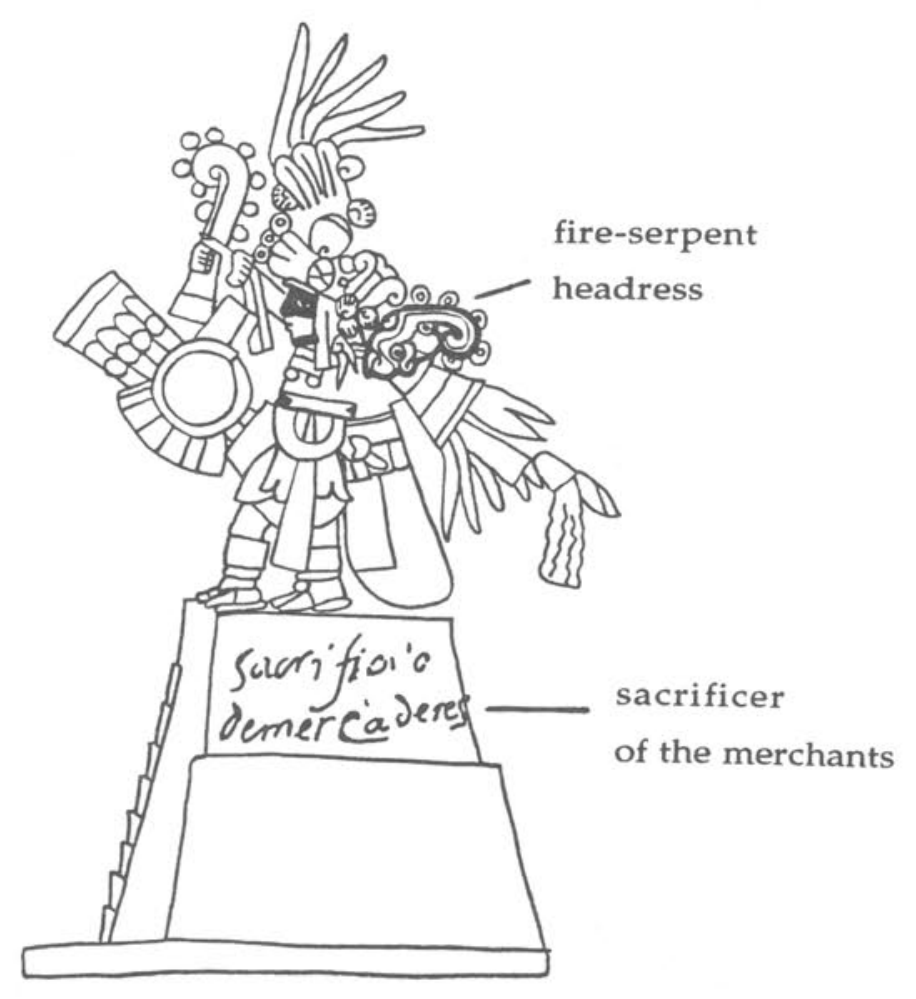

Figure 2: Aztec Fire-Serpent Priest in Codex Borbonicus 33.

However, other sets are not related to any one individual like Lord 8 Deer, but rather pertain to a variety of persons engaged in several, very specific ritual activities. Figures $1 \mathrm{~b}$ and 1c show two similarly attired characters, priests called yahui in Mixtec (Smith 1973b). They both wear a tortoise shell on the torso, a sea shell at the nape of the neck, a fire-serpent headdress, and a flint-bladed tail ornament. (12) Yet the figures represent two entirely different people. The first, 3 Lizard, appears only one other time on Zouche-Nuttall 13 (Fig. 1d). Here, he is shown in garb more typical of a lord in the codices. His personal name, "Flint Band ", appears on his head. The second, Lord 8 Deer, appears throughout the manuscript. He displays tremendous variety in his overall garb, but this is a rare instance when he is depicted in clothing shared by another elite personage. Although these two appearances alone do not convey just what roles these men might have fulfilled, some idea of their position is suggested by an Aztec image of a fire-serpent priest in Codex Borbonicus 33 (Fig. 2). A Colonial scribe identified the figure as a "sacrificer of the merchants." In the Mixtec codices costume, therefore, serves:

1) to identify individuals in more specific terms than calendrical or personal day signs. 
2) to qualify the nature of social or political activities in which individuals participate, such as war, marriage, and death.

3) to relate groups of people to each other, such as priests, elders, lords, or any other persons who form some symbolic bond between themselves either political or ethnic.

\section{SUCCESSION AND THE REVELATION OF POLITICAL POWER}

By far the highest percentage of appearances of non-paramount elites in the codices occurs with the foundation accounts of Vindobonensis and Zouche-Nuttall and with the 8 Deer story in Colombino-Becker and Zouche-Nuttall. Significantly, these narratives are what anthropologists would perceive to be "crisis events" in a society's political history. What is fascinating about Codex Vindobonensis, in marked contrast to comparable Aztec foundation stories pictorialized in Codex Mendoza or Boturini, is the vast number of personages that are involved with the establishment of the first kingdoms. The complexity of a Mixtec pantheon based on the worship of multiple dynastic ancestors is clearly revealed, as is the creation of particularized roles for personages who appear in later accounts not as rulers but as political functionaries.

The 8 Deer story, on the other hand, is a classic tale of usurpation in the succession to high office. It is precisely at times of succession that the full panorama of political complexity will suddenly reveal itself. From the highest-born prince to the lowest of peasants, all are affected by the potential breakup of power vested in a paramount position (Goody 1966). The 8 Deer story is significant because it allows us to examine the particulars of elite social behavior as the Mixtec themselves perceived and idealized them. The life of 8 Deer, therefore, serves us as a pictorialized case study in political action and reaction.

Equally important to this study are documents relating to 16th-century idolatry trials in the Mixteca Alta (Jiménez-Moreno and Mateos Higuera 1940, Spores 1967). Between 1544 and 1546, three Mixtec noblemen were accused of idolatry and heresy in Yanhuitlan. The accusations brought forth in the trial are among the most detailed, extant records of native religious practices for the early Colonial period in Mesoamerica. The god list includes names for deities pictorialized in Codex Vindobonensis, and descriptions of pagan worship through the reverence of sacred bundles have direct correlations with ritual behavior in Codex ZoucheNuttall. More important are the circumstances under which the noblemen were first accused and later acquitted despite several confessions of guilt.

Yanhuitlan had recently been the focus of social turmoil between evangelizing Dominican missionaries, the Spanish encomendero Francisco de las Casas (cousin to Cortés), and a native administration, whose cacique may have stood in direct conflict with the encomendero over control of land and tribute (Spores 1967). The principal defendant was named Don Domingo de Guzmán, a descendant of Lord 8 Deer, and described as both "cacique" and 
"gobernador" of Yanhuitlan (Jiménez Moreno and Mateos Higuera 1940: 62).

Apparently, Don Domingo was only serving as regent at Yanhuitlan. The legitimate Mixtec heir to the cacicazgo, Gabriel de Guzmán, was too young to rule and resided with his parents at Tamazola. Two other "gobernadores" were also indicted, Don Francisco and Don Juan. Don Francisco was the caretaker of twenty sacred bundles, while Don Juan was accused of human sacrifice and preaching to the people to venerate the rain and merchant gods. Upon Don Francisco's arrest, the sacred bundles were seized, curiously, by the encomendero Francisco de las Casas (Spores 1967: 230-231). The seizure implies that more was played out at the trial then simply accusations of idolatry, especially since the heretical behavior of the accused was also associated, as we shall see, with native rites of royal succession and, ultimately, control of the Yanhuitlan cacicazgo. Based on an analysis of behavior both in the codices and in Colonial accounts, I will present four basic groups of people whom I have identified as part of a Mixtec political hierarchy in the following chapters. These are:

1. The Four Priests: representing political stability.

2. The Yaha Yahui: supervising sacrifice and economy.

3. Supernaturals: offering oracular arbitration and national cohesion.

4. The Tolteca-Chichimeca: embodying outside influences. 


\section{THE FOUR PRIESTS: POLITICAL STABILITY}

Most administrative systems in traditional societies employ persons who not only smooth the transition of high authority following the death of the paramount but provide checks and balances to the ambitions of those hoping to succeed. The positions these personages hold are integrated into the hierarchy of government. This study considers the nature of a hierarchical system maintained by the Postclassic Mixtec as reflected in the codices. The object of this chapter is to 1) define the roles that priests played in the system, as officials ("regidores" or "gobernadores" to the Spaniards) who provided checks and balances to high authority, and 2) to illuminate the general structure and function of ancient Mixtec government in general.

Unfortunately, the documentary evidence on the management of authority within these factionalized realms is scanty. The Mixtec were not subject to the initial shock created by the Conquistadors, and during the Colonial period the Spanish found it more convenient to incorporate native regional control rather than reorganize it. There was no significant relocation plan, and the control of many cacicazgos (a Spanish term for native territorial units) was maintained within a native royal line. Spores (1984) proposes that the integration of Mixtec culture into Spanish Colonial society was greatly facilitated not to overt subjugation by an intrusive Spanish elite, but by the efforts of the Dominicans, who sought to insert themselves into existing social patterns. These early Dominican friars did not, however, produce the detailed studies of native culture provided by Sahagún, Durán, and others for the Aztec. Fray Francisco de Burgoa's works were written in the late 17th-century, nearly 150 years after the Conquest. (13)

On the other hand, political interactions are portrayed in considerable detail throughout the pictorial manuscripts of the Mixtec, and careful analysis of the painted narratives can reveal much about administrative management. In this chapter, I will first discuss some basic characteristics of social stratification rooted in elite kinship and the roles non-paramount personnel played during the transition of authority in such systems. Next I will discuss the roles of priests in the more detailed codical narratives, and finally, with ethnohistorical data, I will suggest how the positions these persons occupied related to the paramount as parts of an administrative system. Specifically, I will concentrate on a group of judicial personnel who functioned as counselors to the king.

\section{SOCIAL STRATIFICATION AND ELITE KINSHIP}

The development of social organization in the Mixteca during the Postclassic was closely tied to shifts in settlement, population increase, and the intensification of terraced agricultural practices (Spores 1967, 1972, 1983, 1984; Byland n.d.; Byland and Pohl in press). As 
the Mixtec adapted to these environmental and cultural changes, so evolved the need for administrative authority to promote organization. At the time of the Conquest, elite administration was rooted in an extended kinship system composed of multiple royal descent groups or lineages called tnuhu in Mixtec (see Pastor 1987). Burgoa (1934 I: 276,369) stated that the highest ranked of these lineages was the royal house of Tilantongo. Rank in Mixtec social organization consequently became contingent on descent. This is nowhere more evident than in the codical records themselves. Codex Bodley reverse, for example, presents over 500 years of descent reckoning for the kings of Tilantongo. Regarding descent, Irving Goldman proposed that:

"Descent can be understood as rules of affiliation or as rules of subdivision of kin groups. Since membership in a kin group conveys a variety of rights and corresponding responsibilities, descent may be considered more specifically as the valid, the truly authentic way of participating in such rights and responsibilities. Whether seen as the means of forming kin groups, as a method of affiliation to kin groups, or as the vehicle for transmitting rights and exacting responsibilities, descent appears in general social theory as technical rule, as a device for establishing effective order among kin." (Goldman 1970:419).

Seniority in rank is reckoned through descent by primogeniture, a fundamental aspect of many elite kinship systems. It was a "preferred" system for the transference of authority among the Mixtec. (14) At the family level the consequences of being a junior member are not so serious as at the administrative level. This is because an individual's proximity to the ancestor of the royal line not only directs inheritance of family property but also justifies control over the government of society. The possibility of gaining the high position was of serious concern among royal siblings. Therefore, primogeniture not only served as a convenient means of granting authority, but it also firmly established a traditional means of electing a successor. Furthermore, primogeniture served to limit the size of the elite class. Sahlins stated:

"As a consequence of seniority, the descendants of an older brother rank higher than the descendants of a younger brother. In any given group which is descendant from a common ancestor, we can distinguish a senior line from a number of junior lines. Every individual within this group of descendants from a common ancestor holds a different status, one precisely in proportion to his distance from the senior line of descent in the group." (Sahlins 1958: 141)

Thus, rank within the royal line effectively produced a paramountcy and a system of downward mobility through time as junior members of a ruling family produced lines which became successively more distant from the ancestor, consequently filling the lower ranks. For the Mixtec, these ranks formed a class of princes called tay toho (Spores 1984: 64). Among the 
Zapotec, the priesthood was selected from this same junior nobility (Burgoa 1934 II: 168). The system of primogeniture therefore ideally insured that the firstborn would continue the most direct line to the founding ancestor.

Goldman sees a general evolutionary trend in many societies from what he has labeled "Traditional", to "Open", to "Stratified" forms of organization based on an analysis of cultural evolution in Polynesia. Warfare becomes characteristic of "Open" societies as kinship groups begin to dominate one another by force and militarily stronger groups focus their authority at the top of the social hierarchy. Indeed the Oaxacan Formative period (Monte Alban I and II) was characterized by intensive raiding patterns which allowed Monte Alban eventually to overcome its neighbors by military domination (Flannery and Marcus 1983: 79-83, Marcus 1983a: 106-108).

In "Stratified" societies, the high authority and members of his line often become deified as the title passes to descendants by rule of primogeniture (or some other predetermined positions of heredity). The Mixtec term for the "authority of the lord," for instance, means "to be held by god" (Pastor 1987: 26). The deification process has the effect of further insuring the ritual sanctity of the royal line but more importantly of preserving the order of the hierarchy now so basic to governmental administration. Since important rituals involving the deified paramount are essentially "religious," persons who administer the religion as priests necessarily play important roles both in the sacred and secular realms of authority. They control the ritual basis for popular belief in royal sanctity through a deified ancestor and thereby handle the sacred objects involved in both the cult and the rights to hereditary authority by the royal line. In religious and political systems characterized by elaborate rituals like those of the Mixtec, an examination of the ceremonies of succession can therefore reveal much about social hierarchy and the roles of authorities.

Succession is a critical event to a study of rank because it is a time, when the high authority changes, that the elite class reestablishes its relationships both within itself and to the paramount position by reevaluating the rules of descent. During ceremonies of succession, priests, noblemen, and members of the high authority's family must meet to decide who will succeed and to formalize--often with great ritual--the installation of a new head administrator. Succession to high office is seldom a smooth operation. This is especially clear in the highly competitive universe of Mixtec factionalism portrayed in the codices, a universe where problems in the transition of authority are resolved by war.

Where the royal family is concerned, the transference of property also entails the position of head of state. The power factor involved stimulates the ambitions of not only junior members of the royal family, but also higher ranking officials of the whole elite class (generals, priests, lesser noblemen who try to begin new dynasties). Few will bypass the opportunity to elevate their positions. However, the pressure from persons of lower rank to elevate themselves in the administrative hierarchy runs against the current of downward mobility idealized in the primogeniture system of the sacred royal line. Thus, ambition for 
status can lead individuals to try to alter the system by intrigue or by force. Such persons put themselves before the preservation of the governmental administration, and they become dangerous to the framework of society. An evolving social system with defined ranking only has to experience once the turmoil brought about by the failure of a high authority to produce a viable heir before it learns that controls over succession practices must be maintained.

Jack Goody (1966:10-12) has defined two types of authority that can act to smooth the transition of power during an interregnum: stand-ins and stake-holders. Summarizing material from African kingdoms, he described the nature of these positions in five societies. The standin serves as a temporary high authority and usually the position is filled by a person who, by order of birth or distance from the royal line, is excluded from making permanent claim to the high position. Stake-holders, on the other hand, are persons who take charge of the emblems of authority, the royal regalia, during the interregnum. These emblems are the material means by which the high authority publicly demonstrates his position. The emblems themselves become charged with the authoritative power of tradition as they are passed from one generation to the next.

Like the stand-ins, stake holders are also excluded from permanent control through their distance from the royal line. For instance, among the Bemba (Goody 1966:11), a group of priest-counselors takeover, while among the Ashanti it is a more generalized group of lower administrative officials. R.S. Rattray (1929: 83-88) outlines the process of succession among the Ashanti chiefs.

"The real hereditary power of chiefs is attributed to stools. Upon the death of a chief, the ancestral stools (literally the seats of authority of former chiefs) are taken by the wirempefo, the body of lower officials, together with the white stool belonging to the dead chief, which is blackened, to become an ancestral stool. The blackened stools, normally kept in the royal household, are both the focus of the ruling family's ancestor cult and the principal objects used in the accession ceremony. The wirempefo, however, maintain the stools until the proper time after the dead chief has been interred and the heir has been ceremoniously recognized...

The enstoolment ceremony proper, which in many cases only a select few ever witness, consists in the new chief being led forward to where the most important of the blackened stools of his dead ancestors is placed. This stool...is the shrine in which a departed spirit rests. Upon it the new chief is placed for a second, and lifted up; and the process is repeated three times. Then and not until then has he been 'enstooled.' From now onwards he is invested with all the sanctity and the power of the dead until such time as he dies or is destooled, i.e., made to sever by force the spiritual connection." (Rattray 1929:84)

Ashanti religious ideology attributes a sacred ancestral power to the stool. Therefore, one who possesses the stool also possesses the power of the ancestors: the prerogative of rulership. However, only within the possession of a person of royal blood can the power of the 
stool be activated, and blood is defined through kinship. Consequently, one means by which the Ashanti assure that the power of the high authority is transferred smoothly is by the symbolic and temporary seizure of the emblems of power by non-royal persons.

\section{SACRED BUNDLES AND THE ÑUHU CULT}

"Power" objects imbued with the sanctity of royal authority through ancestral descent, much like the Ashanti stools, were manifested in Mixtec society through sacred bundles (Byland and Pohl in press, Furst 1986:62). Bundle cults have been found at the core of American Indian religious practices and social organization from Alaska to the Amazon. Nowhere has their traditional form and use been described in more detail than in the religious practices of many Great Plains United States-Canadian tribes, particularly the Blackfeet and Pawnee (see Wissler 1912, 1920).

The Blackfeet of Southern Alberta and Montana are distinguished by their veneration of sacred bundles in connection with virtually all religious practices (Mcklintock 1935, Reeves 1993). The opening of bundles and the handling of the objects within them are the most holy of acts accompanied by elaborate rituals, prayers, singing, dancing, and recitations of tribal history. Bundles are associated with powerful dreams that were experienced by culture heroes during which mortals actually spoke with the most potent spirit powers (Bullchild 1985). The spirit powers then gave the bundles to man along with the proper songs for invoking their magic (Figs. 3 and 4):

The possession of sacred bundles is tied to political organization through membership in "societies," resulting in the creation of one of the most complex social systems to have evolved on the western plains (Reeves 1993). It is notable that members of warrior societies (see Mcklintock 1938) are traditionally prohibited from possessing the most powerful bundles. The Beaver bundle, for example, is synonymous with concepts of tribal unity, and restrictions in possession point to checks in the authority of the militant components of tribal organization. The possessor of the Beaver bundle, on the other hand, could be a tribal judge (Mcklintock 1935: $6)$.

B.O.K. Reeves (1993) has proposed that the songs and prayers performed with bundle opening rituals invoke cycles of legends that are associated with place naming in the Piegan landscape. These locations are archaeologically significant (the "Head's Smashed In" Bison Jump is a prime example) and had been critical to seasonal migration and environmental exploitation patterns in hunting and gathering (Reeves 1978). To the Blackfeet, sacred bundles are not simply holy objects in and of themselves, but serve as ritual symbols for critical forms of information exchange and the definition of tribal cohesion.

Werner Stenzel (1972:351) has likewise outlined fundamental elements of bundle worship in ancient Mesoamerica. The bundles were and still are holy objects wrapped in layers 
of cloth. They are viewed as containing supernatural "power" or "energy," often likened to wind (Mendelson 1958:123). The opening and closing of bundles constitute important social rituals which provide access to "power." At such times invocations are made to the bundles, usually as prayers for social welfare, weather control, and war.

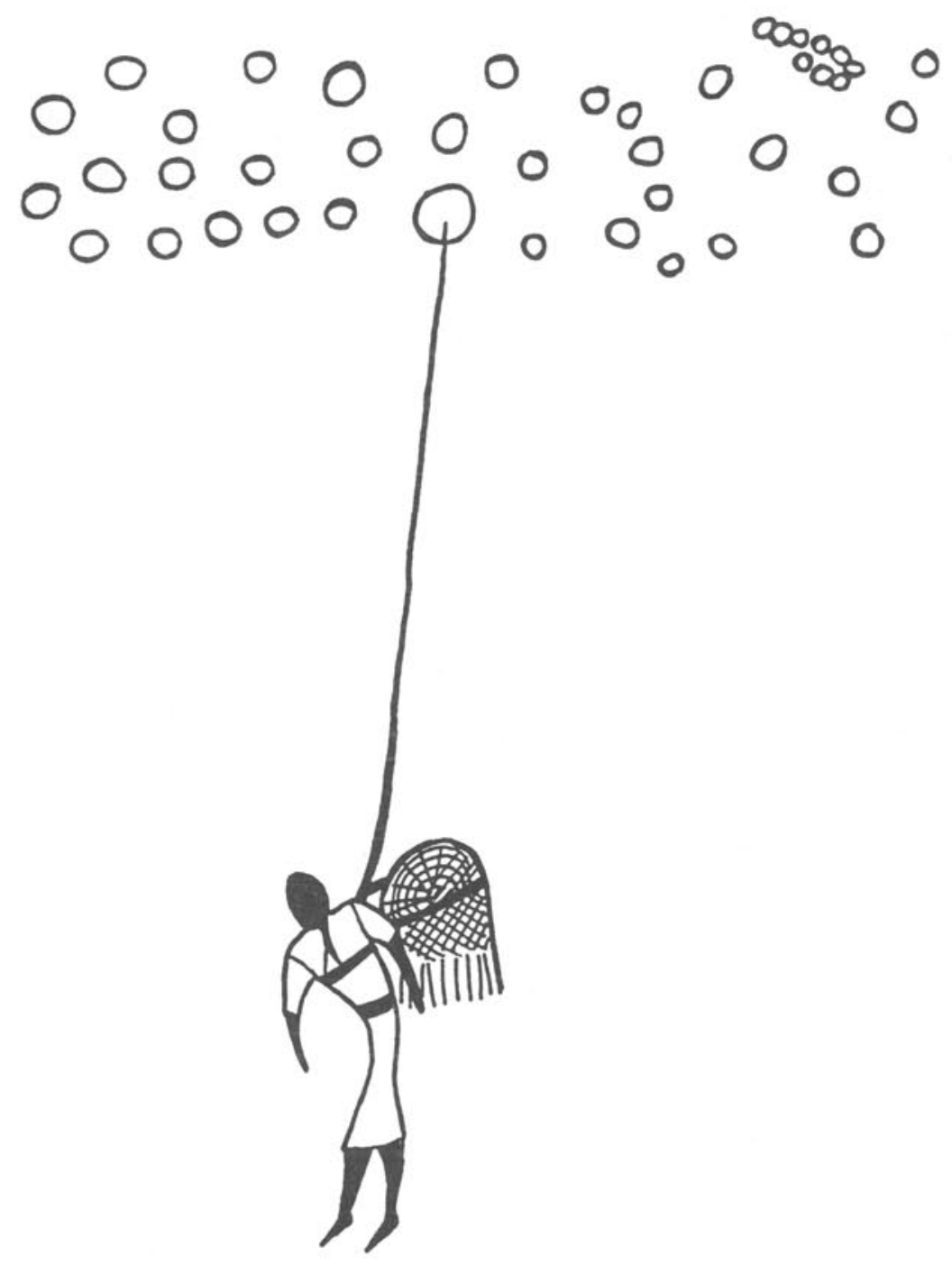

Figure 3: A Piegan culture hero descends from heaven on a rope with the Ancient Pipe Bundle (redrawn after a hide painting by Percy Bullchild, 1985:286). Blackfeet sacred bundles are not only a primary focus of religious veneration, they serve as symbolic objects to be manipulated in the course of critical information exchanges in the society. Tribal members gain prestige through possession of bundles and each bundle entails different kinds of social obligations. The possessor may also be entrusted with memorizing hundreds of songs and stories containing cognitive maps prerequisite to environmental exploitation. 


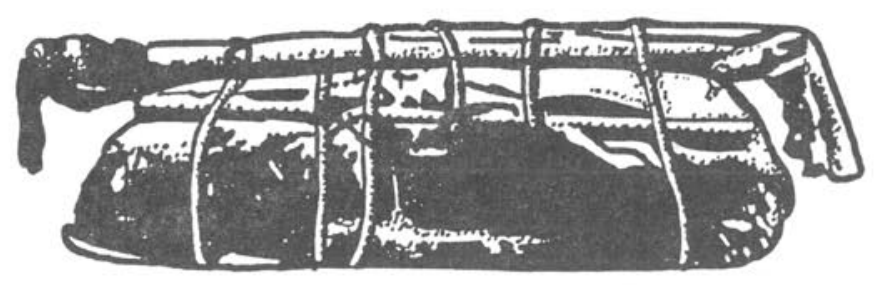

a
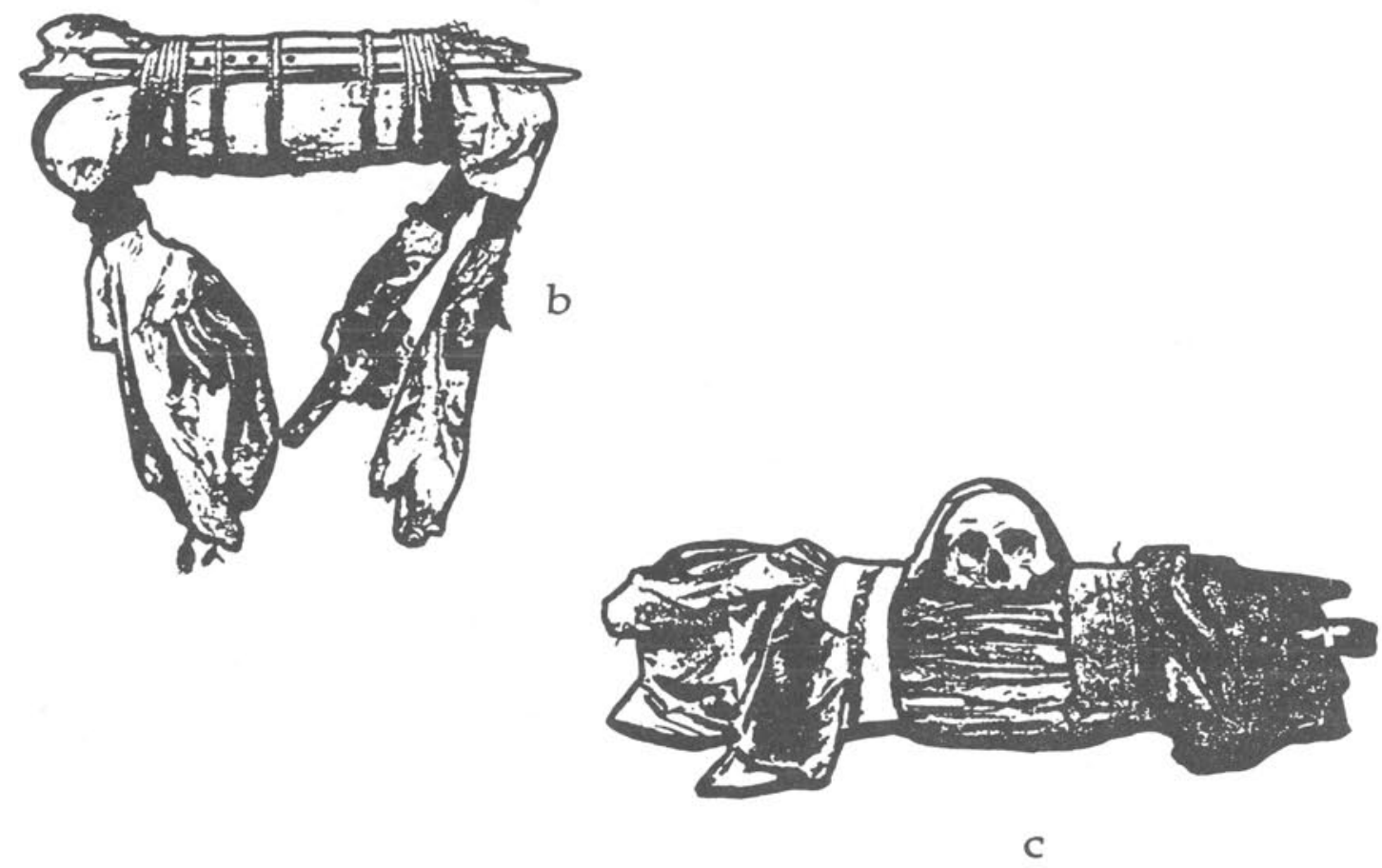

Figure 4: (a) The Blackfeet Sacred Beaver Bundle (McClintock 1935: 14). (b) The Pawnee Evening Star Bundle with fire making implements (Chamberlain 1982). (c) The Pawnee Skull Bundle surmounted by skull of first Pawnee man (Chamberlain 1982). 
Bundles are commonly associated with the creation of the world and the migrations of the group. There is often a connection between the bundles and some form of kinship group hierarchy which includes a supreme sacred bundle which is viewed as the chief focus of social unity. Finally, chieftancy or kingship is based on and/or traced back to the possession, preservation, or taking care of sacred bundles. (16)

Sacred bundles are found with uncommonly high frequency in the accounts of divine origin in Codex Zouche-Nuttall obverse and in the 8 Deer story, in both Zouche-Nuttall reverse and Colombino-Becker (Fig. 5). In the Zouche-Nuttall reverse it appears five times. It is present at the beginning of the account on page 42, and displays the head of the culture hero 9 Wind as a qualifier. On page 52 it appears before Lord 4 Jaguar from whom 8 Deer receives a nose ornament making him a lineage head (see Chapter IV). On page 68 it is shown being borne by one of three priests for 8 Deer and his half-brother, Lord 12 Movement, on a peregrination. This act culminates in a sacrifice performed before a fourth appearance of the bundle by another priest, 8 Deer's brother, Priest 9 Flower. Finally, on page 83 , it is present at the sacrifice of 8 Deer's two half-nephews, Lords 10 Dog and 6 House.

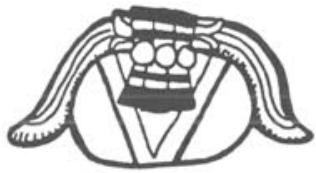

a

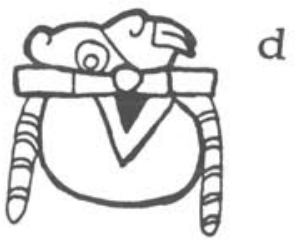

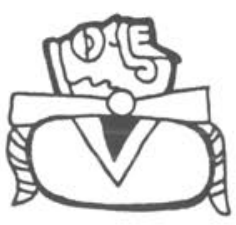

b
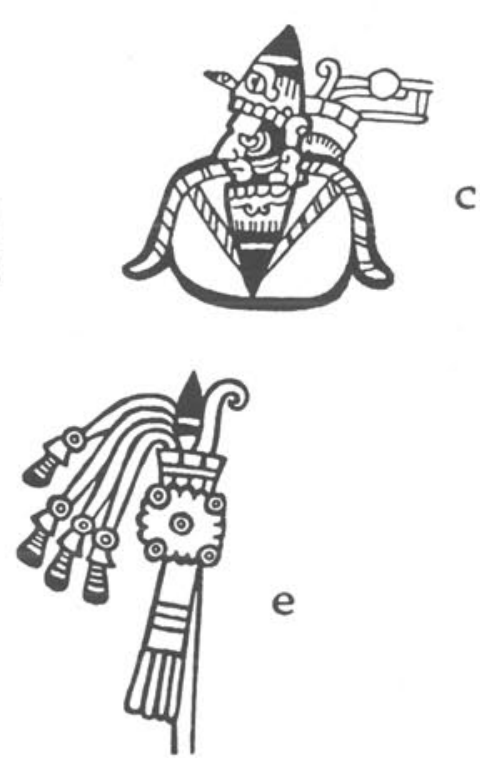

Figure 5: Sacred bundles in the Mixtec codices. (a) bundle wrapped in layers of white cloth an tied with a red and white triple-knot bow (Zouche-Nuttall 69). (b) bundle surmounted by an effigy head of dzahui, the rain deity as in Figure 7 (Selden 3). (c) bundle surmounted by flint effigy of the culture hero, 9 Wind (Zouche-Nuttall 15). (d) bundle surmounted by effigy head of the $n u h u$ or earth spirit-force (Selden 3). (e) the "venus" staff that often accompanies the sacred bundle. 
In the Colombino-Becker, the sacred bundle appears more frequently, including cognates to the scenes in Codex Zouche-Nuttall just discussed. It is carried on 8 Deer's behalf to Tututepec (6II, 5II, and 5I), where the conqueror and his brother, Lord 12 Movement, appear. Smith (1973a: 67-68) proposes that 8 Deer became ruler of that kingdom. Later on (Colombino $14 \mathrm{III})$, the bundle is carried by a personage during 8 Deer's peregrination to see 4 Jaguar and to receive the nose ornament. The group travels through several successive places, each of which has its own sacred bundle (Colombino 14III-II).

A significant detail of the bundles portrayed in Colombino-Becker is that they are surmounted by the head of a deity unique to Mixtec codices, very rarely, if ever, appearing in the art of other Mesoamerican traditions (Fig. 5d). Although badly damaged, the first and third place signs on Colombino 14III and 14II show that the head is colored red with a large round eye, two sets of knobby "horns," and the remnants of fanged teeth. This figure makes its most frequent appearances in the Codex Vindobonensis Obverse. Here it is found over twentyfive times in highly ritualistic contexts. On page 27 it appears as a limbless dwarf with an ear of corn growing from its head. Just to the lower left is the same figure directing the falling rain (Fig. 6a and b).
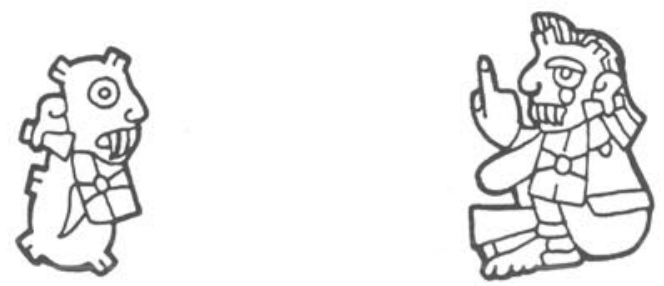

Figure 6: The nuhu figure in Vindobonensis 22 and 27.

The creature seems to be some sort of supernatural, not only because of its unusual form, but because of its highly symbolic usage. It may serve as a personal name, a place sign qualifier, and a bundle qualifier. Smith (1973b:65-71) has identified Spanish glosses in the Codices Muro and Egerton associated with personages bearing name glyphs that include the dwarf-like figure. From her work we know that the figure is called a $\tilde{n} u h u$ (noho) a term possessing some very significant linguistic associations that are born out iconographically. According to the Arana and Swadesh (1965: 110-111) dictionary, nuhu means:

- God

-Spirit

-Land , Earth

-Sun 
It would appear, therefore, that the $₫ u h u$ figure represents a primary spirit force in Mixtec religious ideology. In place sign qualifiers and personal names, the $n u h u$ is sometimes shown emerging from the earth or a jewel, displaying the same pose and gesture peculiar only to the first ancestors who emerge from the earth or trees. The god steps out of a crevice, usually with its arms upraised, with its hands outstretched or pointing (for instance, compare Selden 13IV, 14II, 14IV, and Becker I:9II with Zouche-Nuttall: 9A or Selden 2I). The $n u h u$ head qualifies the contents of the sacred bundles in many Codex Selden accession scenes. Page 14IIIIV is typical in showing a lord burning incense to such a bundle before becoming a ruler of Jaltepec and marrying. The word for temple in the Alvarado dictionary is huahi nuhu or "nuhu temple," and the ruins of the Postclassic temple at Jaltepec are still called vehe $n u h u$, or "fuhu house" (Byland and Pohl: in press). (17)

Depiction of the head of the $n n h u$ spirit or an ancestral deity surmounting the sacred bundle may refer to the bundle's contents. Codex Selden 3 I-II shows the preparation of twenty bundles for the first lord of Jaltepec by two aged priests. The first bundle is surmounted by the head of the lord's mother who appeared in a previous scene. The 1544-1546 Inquisitions of Yanhuitlan likewise describe twenty sacred bundles which contained idols. One was called zaguii (dzahui), after the name for the Mixtec rain god. Among the greenstone images (called penates) found so commonly in the Mixteca, several portray the rain deity dzahui and were doubtless included in sacred bundles (Fig 7.). John Monaghan (n.d.a.) found that dzahui is perceived as the chief of the fluhu in the Mixtec community of Nuuyoo. The Mixtec refer to themselves as the fuu dzahui or "People of dzahui".

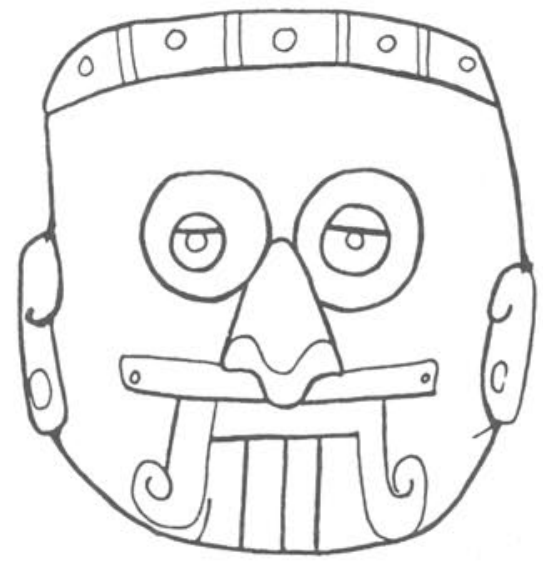

Figure 7: Greenstone effigy mask of dzahui in the collection of the Metropolitan Museum of Art. 
The prinicpal idol of Yanhuitlan was called the "idolo del pueblo" (Jiménez-Moreno and Mateos Higuera 1940:40). Burgoa (1934 I: 332) describes an idol at Achiutla that was similarly referred to as the "corazon del pueblo." It was about the size of a pepper and made of green stone. A fascinating wooden image of a nuhu is also found in the Vienna Museum of Natural History. Because of its diminutive size and form, it was probably contained in a sacred bundle as well (Nowotny 1949, Pohl n.d.a.). It is distinguished by the large round eyes, fanged teeth, and horns. What is so curious is that the Vienna $n u h u$ is giving birth to a tiny king who emerges between its legs, even though the figure also possesses male genitalia (Fig. 8).
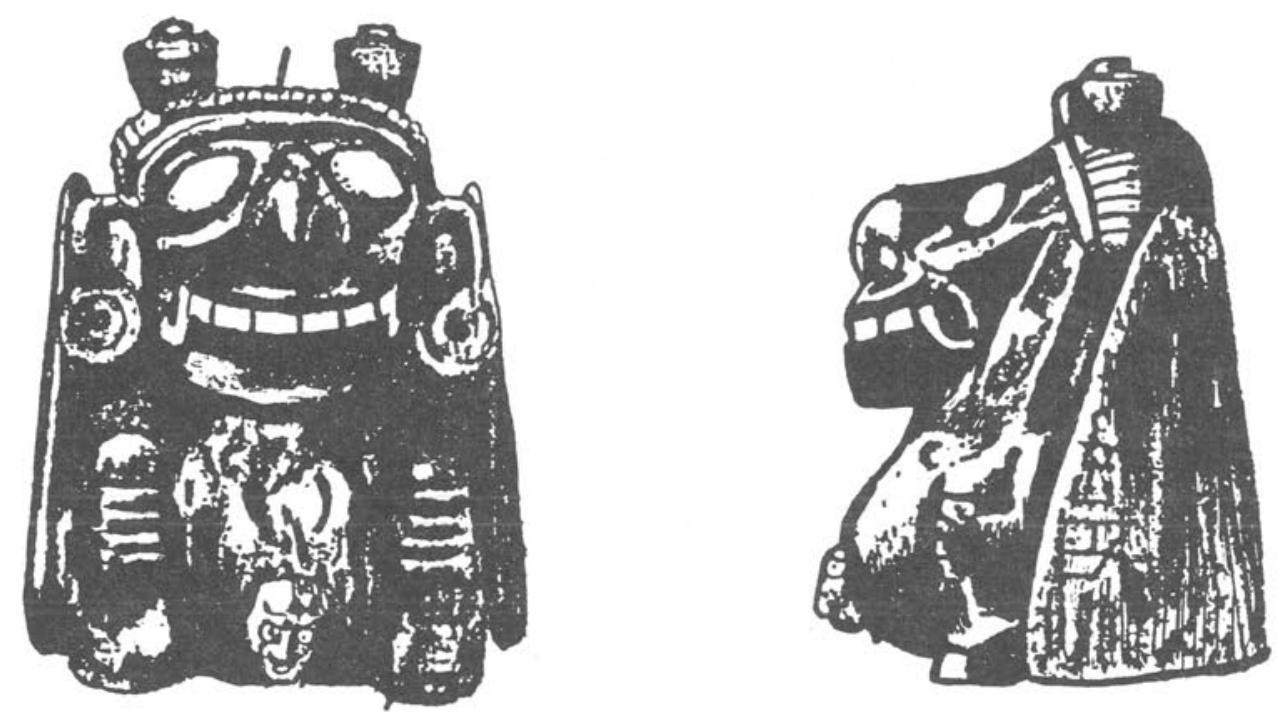

Figure 8: Wooden fuhu effigy in the collection of the Museum für Völkerkunde, Vienna.

From both the pictorial and linguistic evidence, we begin to form a picture of Mixtec religion that focuses not only on ancestor worship but on a more generalized spirit force as well. The two may even be synonymous. Caso found that the term for a dead king, $\curvearrowleft u$, is a conjunction for $n u h u$, the spirit force (Caso 1962: 126). Indeed, the modern Mixtec still maintain a strong link with the fuhu. According to Robert Ravicz and Kimball Romney (1969:373, 394), the earth is seen as a living dynamic force that has become an integral part of the Mixtec personality. Springs, streams, and swamps, for instance, are especially invested with the power of a spirit who dwells there or is simply imbued with some kind of supernatural energy. 
More recent research has found that many of these spirits are in fact seen as nuhus (Monaghan n.d.a.). They appear to be a Mixtec variation of the duento, or "earth lord" concept that is so widespread in Mesoamerica today (see Jansen 1982a: 295-311). The modern people of Apoala address as nuhus huge stone fragments that have fallen from the valley walls (Jansen n.d., 1980, 1982a), and the people of Tilantongo refer to dueños or spirits in the Valley that are called nutilus (nuhu tilu). Figure 9 shows four stone heads from San Pedro Yucunama near Texupan. They are typical of carvings found throughout the Mixteca today, and although the Yucunama people could not identify them for this author, Kathryn Josserand (personal communication) has seen them in Peñoles where they are addressed as nuhus. Even in stone relief they bear the large round eyes and fanged teeth of this being.
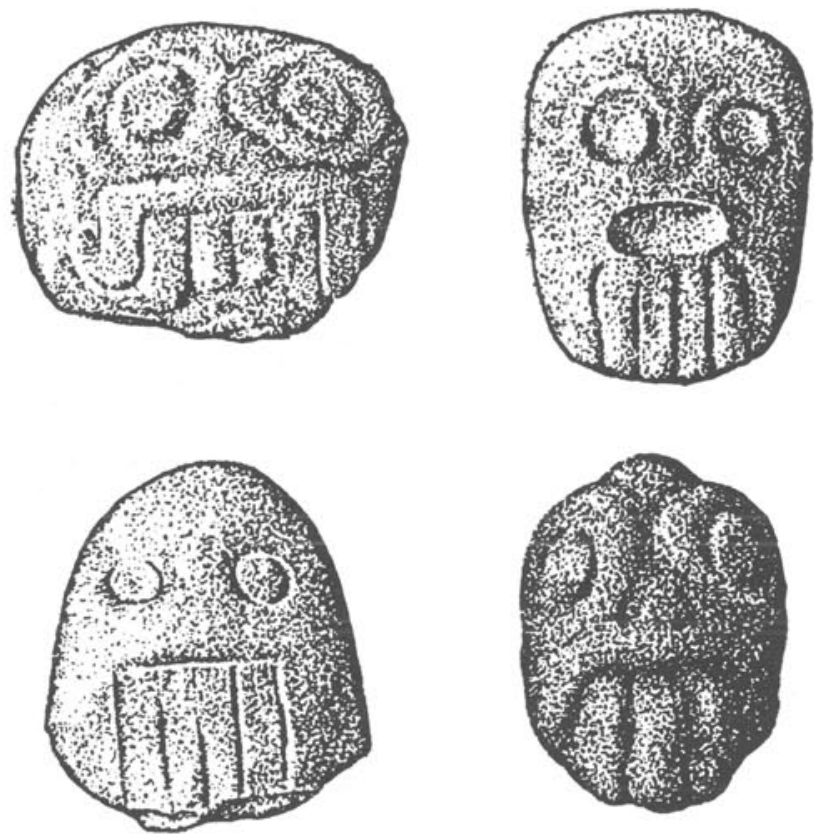

Figure 9: Stone $\tilde{n} u h u$ heads from Yucunama, Mixteca Alta.

The $\tilde{n} u h u$ deity concept was and still is at the center of a traditional form of Mixtec spiritualism. It is noteworthy that the power embodied in the god is represented in the bundle that was the most important object of veneration for Mixtec lords. It will become clearer below, however, that there were different kinds of bundles, some of which represented specific founder lords such as the culture hero, 9 Wind.

Perhaps the reason for venerating the $n u h u$ can be seen in a myth recorded by Antonio de los Reyes (1976: I-II). The lords who were born from trees in Apoala and who divided the 
land and established the first kingdoms were not the original inhabitants. These kings had to subdue an indigenous group of Mixtec who were called the tay $n u h u$ because they were said to have come from the center of the earth (tay--people, nuhu--earth) (See Smith 1973b).

\section{THE BUNDLE PRIESTS}

Codex Vindobonensis 14-15 depicts a scene in which four individuals present objects before Lady 9 Grass. We know that Lady 9 Grass was a highly venerated authority in Mixtec political affairs (see Chapter IV). She is commonly involved with lords and ladies exhibiting ambition or displacement during turmoil in the codices. She was also one of the first ancestors and presided over a religious cult important to the royalty of Tilantongo and Jaltepec (Byland and Pohl: in press).

The roles of the four other individuals are not so clear, and we may only describe them by their most distinctive costume attributes (Fig. 10). They are all wearing black face and body paint, their hair is twisted, and two of them wear skeletal jaws. These personages also appear on page 36 of Vindobonensis where all four wear the death mask. Herrera (1944 IV 13:!68-169) said that the black body paint was distinctive of Mixtec priests, being the result of rubbing henbane into the skin and the continuous burning of pine pitch in their "monastaries." (19) $\mathrm{He}$ goes on to say that their clothing was often white and daubed with black color from rubber "gum", doubtless a reference to the black and white xicollis of priests in the codices.

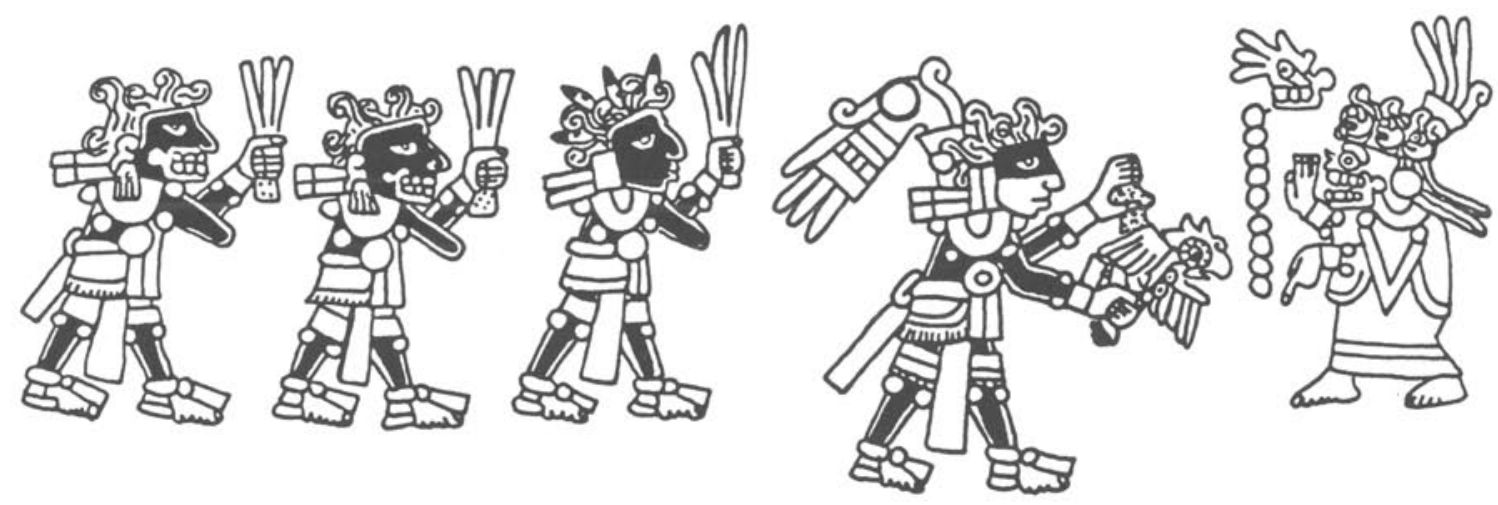

Figure 10: Four priests venerate the oracle 9 Grass (Vindobonensis 15-14).

Zouche-Nuttall 4 B-C shows a scene very similar to that just described. Again we see four priests with twisted hair, black body paint, and skeletal features; two are wearing black 
and white shirt-like "xicollis" (Anawalt 1981: 135). They present sacred objects to a lord wearing secular garments, here expressing personal and military prestige. The similarity between these scenes suggests a kind of institutionalized ritual, and in fact there are a number of similar events depicted throughout the pictorials, in which a body of priests, often four, interact with the most powerful rulers. In many instances, the priests appear as caretakers of the sacred $\tilde{n} u h u$ bundles and emblems of authority for the lord. One title for a Mixtec religious leader was "dzutu sandidzo $\tilde{n} u h u "$ or "priest who carries the $\tilde{n} u h u "$ (Alvarado 1962: 185b).

A behavioral analysis of the pictorial representations of priests in the codices, reveals specific activity patterns both in relation to the veneration of sacred bundles and to periods of succession to paramount authority. Codex Zouche-Nuttall obverse features events in the lives of two priests, 5 Flower and 12 Wind, who establish the first religious institutions by bringing the sacred bundles and regalia to several different kingdoms located in the Tilantongo Valley. Lord 5 Crocodile, the father of 8 Deer, lived shortly after 12 Wind, becoming head of a council of four priests at Tilantongo (Byland and Pohl in press). His story is described within the context of the collapse of Tilantongo's first dynasty, after the death of a royal heir and the eventual usurpation of the realm by 8 Deer.

\section{CASE STUDIES}

\section{FLOWER}

Page 15A of the Codex Zouche-Nuttall shows three priests bearing a sacred bundle, an heraldic "venus" staff, and other emblems associated with royal authority. They accompany Lady 3 Flint, wife of the chief priest, 5 Flower. Two of the priests are recognizable by the wearing of black-and-white xicollis and black facial/body paint. Apparently Priest 5 Flower and Lady 3 Flint had miraculously emerged from a cave at a Cliff of Heaven on page 14. From there they arrived at the large temple with a conical roof encircled by a plumed serpent on page 15B. A sacred bundle sits inside the temple. Upon the bundle is placed the head of the culture hero 9 Wind. The red-and-white frieze which qualifies the temple platform is part of the name for Hill or Place of Flints (Zouche-Nuttall 21A, Bodley 14 III), a site located in the southern Tilantongo Valley (Pohl and Byland 1990, Byland and Pohl in press).

Priest 5 Flower appears a second time on Zouche-Nuttall 15. He is now dressed in a black-and-white xicolli and black body paint in the same way as those who had accompanied him earlier. He sheds blood from his ear with a bone awl, as a sacrificial offering before the sacred bundle of 9 Wind (Fig. 11). 5 Flower appears three more times in the codex on pages 16 and 17 , twice he is dressed with the attributes of a priest. In the last instance he sits inside a palace in the act of marrying Lady 3 Flint. 


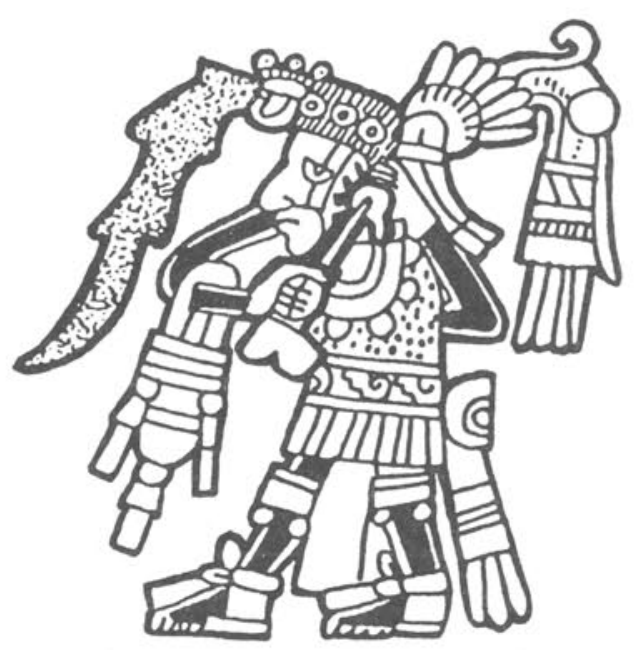

Figure 11: Priest 5 Flower sheds blood from his ears (Zouche-Nuttall 15).

The interpretation of these scenes has been a source of considerable debate in Mixtec codical studies (Nuttall 1902, Dennis n.d.). The problem surrounds confusion over the identity of not one, but two Lady 3 Flints (mother and daughter?) who are the principal subjects of the narrative. Regardless of the confusion, it is clear that page 14 depicts a Cliff of Heaven within the context of other significant geographical locations. Two elders and two priests accompany 5 Flower and Lady 3 Flint to establish the cult of 9 Wind Ehecatl-Quetzalcoatl at a location in the Tilantongo Valley. 5 Flower's first act as a priest is to make an offering of blood from his ear at the institution of the temple and its cult.

The Relación de Tilantongo says that the offering of blood from the ears was a characteristic ritual for the veneration of idols by the priesthood (Acuña 1984: 233). Herrera (1945: 169) said that after a certain period of years in religious service, a priest was admitted to the king's council and permitted to marry. Unlike most of the accounts of marriage in the codices, no children are given as the offspring of the Priest 5 Flower and Lady 3 Flint indicating that the marriage was deemed more to the institution of the cult than to dynastic reckoning.

12 WIND

Following the account of Priest 5 Flower, Zouche-Nuttall 19 shows the descent of four new priests from "Heaven" by means of a rope ladder (Fig. 12). The leader, carrying a temple on his back, is named 12 Wind "Smoke Eye." Before him sits a sacred bundle. What is curious about this scene is its similarity to three other pages in the codex $(19,21,22)$, in which Priest 12 Wind and his assistants are engaged in similar events. In each case, the sacred bundle, the "venus" staff, the temple, and other royal regalia are born by Priests 12 Wind, 3 Flint or an aide, but after the descent from Place of Heaven they arrive at four different kingdoms. 


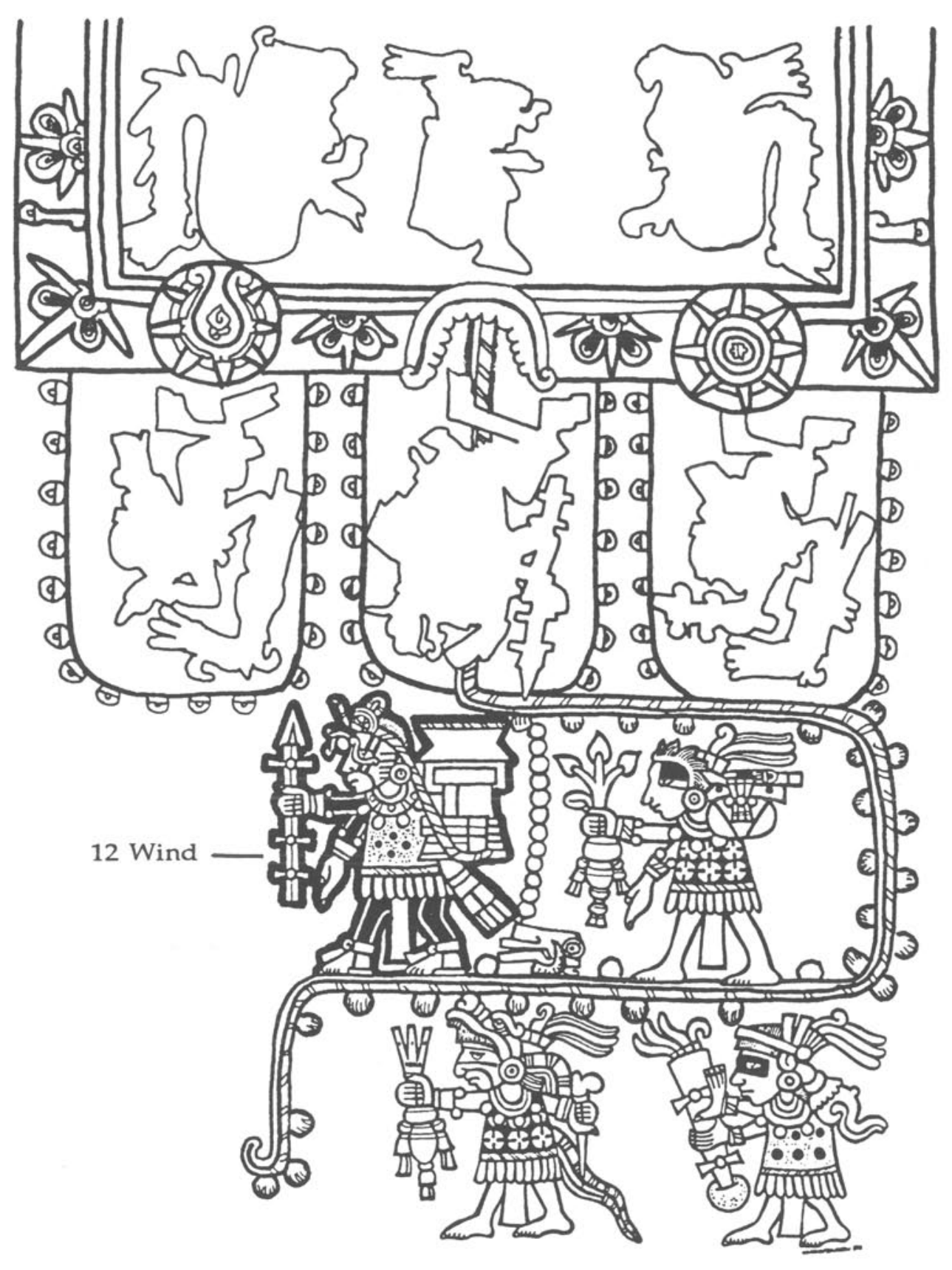

Figure 12: Priest 12 Wind descends from Place of Heaven on a rope ladder carrying a temple on his back. Three cohorts bear other sacred objects, including the sacred bundle (Zouche-Nuttall 19). 
On page 18, 12 Wind appears a second time, burning copal in a sahumador before a temple at Red and White Bundle. The place sign has been correlated with a site lying a few kilometers to the east of Tilantongo (Pohl and Byland 1990, Byland and Pohl n.d.). Again, the temple is encircled by a plumed serpent and contains a sacred bundle like that venerated by Priest 5 Flower.

On page 19 of Zouche-Nuttall, 12 Wind is seated before two gods, who present him with the temple and fire-making instruments which so often accompany the sacred bundle. After the presentation, 12 Wind again descends on the rope ladder from Place of Heaven. He is dressed in a black-and-white xicolli and black face/body paint as are his three assistants. They arrive at a large, composite place sign. In the upper right hand corner is a temple in which sit a "venus" staff and a sacred bundle surmounted by a flint and the fire-making instruments given to $12 \mathrm{Wind}$ in the previous scene. The temple is located at the site of $Y u c u$ Yoco or Hill of the Wasp, a prominent late Classic site located on a mountain above Tilantongo (Pohl and Byland: 1990, Byland and Pohl: in press).

In the lower left-hand corner is another place sign for Hill of Flints. Here sits the bundle of the culture hero 9 Wind that was brought to that place by Priest 5 Flower. The significance of page 19 is not only the magnificent portrayal of the descent from heaven but the pageantry of 12 Wind's marriage to Lady 3 Flint, a daughter (?) of Lady 3 Flint who married priest 5 Flower. On page 20 the marriage scene is repeated, but no children are listed. On page 21, 12 Wind and his chief assistant, 3 Flint, descend from heaven to Hill of the Sun (the Classic occupation site of Achiutla), where they are met by Lady 1 Death and Lord 4 Crocodile, the first progenitors of the royal house of Tilantongo in Bodley 1-2 V. Finally, on page 22 Priests 12 Wind, 3 Flint, and 5 Dog appear at a compound place sign representing Tilantongo itself. They are led by the culture hero 9 Wind himself in this instance, who stands with the sacred bundle in the Temple of Heaven, a prominent shrine in Tilantongo (Pohl and Byland n.d.b.).

To summarize briefly, 12 Wind, like 5 Flower emerges from Place of Heaven. The action emulates the scene in Codex Vindobonensis in which 9 Wind himself is given the sacred bundle and emblems of royal authority, after which he descends on a rope ladder. The results of 12 Wind's activities, much like those of 5 Flower, are the institutionalization of the cult of the culture hero 9 Wind at various communities in the southern end of the Nochixtlan Valley, including Tilantongo itself.

\section{CROCODILE}

Codex Zouche-Nuttall 25 B-C shows three men in priestly costume meeting with a fourth, 5 Crocodile, the father of 8 Deer (Fig. 13). 5 Crocodile's ancestry is listed on the same page, beginning with his grandparents. According to Bodley 6I, his father was a lord of Mouth of the River or Place of the River, a place sign for Ayuta/Atoyaquillo in the Achiutla Valley (See Chapter V). Caso (1960:32) proposed that his mother, Lady 1 Vulture, was a niece of Lord 

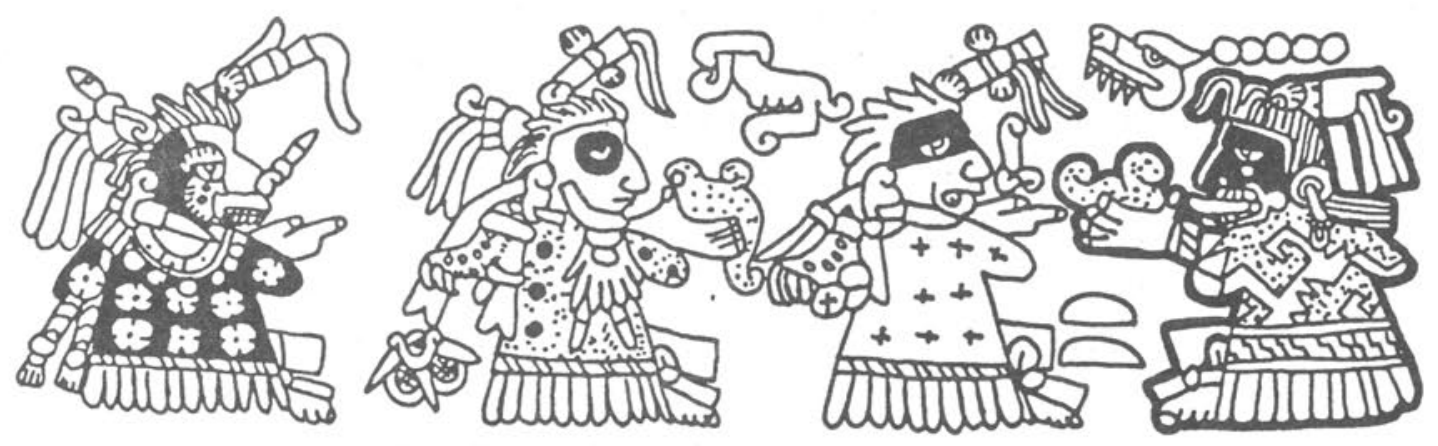

Figure 13: Priest 5 Crocodile meets with three other members of the sacred council of four at Tilantongo (Zouche-Nuttall 25).

12 Lizard, king of Tilantongo. Caso originally believed that 5 Crocodile started a new Tilantongo dynasty after the mysterious death of his cousin, 2 Rain Oconana, a legitimate heir to the throne (Caso 1960: 32). Nevertheless, the meeting between the four priests is unusual because it seems to show an event involving strictly religious authorities rather than "rulers". Because of Emily Rabin's revised chronology, we now know that this event took place at Tilantongo at a time when either Lord 12 Lizard Arrow Legs was king, or his son Lord 5 Movement (see Appendix chronology). Other than the significance of there being four priests involved, we do not know why they are meeting and making offerings.

The Relación de Tilantongo on the other hand, gives us a clue in the description of four priests who acted as the administrative council for the king of Tilantongo:

"A los quinze capítulos dixeron que señor natural tenía quatro regidores los quales le governan todo el Reyno y ante ellos pasaban todos sus pleytos, y después para determinallos yban a su sefior a darle cuenta dellos. Y el más sabio de éstos here presidente y los demás heran sus quavjutores. Y éstos determinaban las cosas de sus sacrificios y de quándo alguno se abía de bender. $Y$ los demás negocios que entre ellos pasaban. $Y$ el sacerdote y patriarca dellos here al que determinabe las cosas de las guerras, y cosas que se abian de hazer, y estos quarto regidores andaban besttidos con unas capas largas de mantas de algodon pintadas a manera de capas de licenciados. Y el sacerdote se bestía el día del sacrificio de muncha plumería y mantas muy galanas y pintadas, y en la cabeca se ponía una mitra, a manera de Obisbo; y quando faltabe presidente elegian al sacerdote que en aquel tienpo here, y el sacerdote no abia de dormir de noche ni beber bino ni illegar muger. Y para hazelle que se desytiese del sacerdocio y no pudiese husar dél, le hazian beber bino y casar." (Paso y Troncoso 1905: 74; Acuña 1984:233). 
It seems therefore that the three priests meeting with 5 Crocodile are involved with his institution as head of the holy council of four, and not as king of Tilantongo. This hypothesis is confirmed by Jansen's (1982a: 378-379) observation that the event follows a series of "awards" in the form of various xicollis given to 5 Crocodile every four years. Herrera (1945: 169), in fact, said that priests were promoted for their service to more prestigious "cargos" every four years by the king.

Following the meeting with the three priests, 5 Crocodile next appears before the Temple of Heaven at Tilantongo, shedding blood from his ear on to a sacred bundle. This is the same act associated with the Priest 5 Flower on Zouche-Nuttall 15 discussed above. A cognate scene appears in Codex Bodley, this time, however, 5 Crocodile burns incense in a sahumador before the bundle, as his counterpart 12 Wind had done in Zouche-Nuttall 18.

Clearly, the bloodletting by 5 Crocodile onto a sacred bundle does not refer to an accession event but rather to a symbolic act associated with the head of the council of four priests at Tilantongo. The reverse of the Codex Vindobonensis 5-6 shows the same presentation scene as Zouche-Nuttall 25. It is notable that here 5 Crocodile is given an additional name or title. It is composed of a small red man with a skeletal head bearing a $n u h u$ spirit with the blood-letter stuck into it. As we have seen, a common appearance of the $\tilde{h} u h u$ is on sacred bundles, and it relates the bundle to the first ancestors and the primary Mixtec spirit force. The symbolic configuration matches the term for priest, as "the bearer of the $\tilde{n} u h u$ " listed in the Alvarado dictionary.

At the time that 5 Crocodile is head of the sacred council at Tilantongo, a series of events unfolds that ultimately leads to the collapse of the ruling dynasty when Tilantongo's king, 2 Rain Ocoñana, mysteriously dies on Bodley 5I. 2 Rain was the son of 5 Movement, a lord of both Red-and-White Bundle and Tilantongo according to Codex Bodley 6II and the Mapa de Teozacoalco. Apparently, 5 Movement's marriage to a Jaltepec woman, and his relationship with Red-and-White Bundle stood in direct conflict to another arrangement that developed between the Jaltepec Lady 6 Monkey and the Red-and-White Bundle Lord 11 Wind. A war broke out in which 5 Movement's son, 2 Rain Oconana, is represented by a champion defeated in a war at Jaltepec. A few years after this setback, 2 Rain himself dies. Given that the place sign with which 2 Rain is associated in Zouche-Nuttall 24 is not Tilantongo, it may be that he was residing with his parents elsewhere, and that 5 Crocodile is operating as both high priest and regent or stakeholder at Tilantongo.

Chart 1 illustrates specific forms of behavior enacted not only by Priests 5 Flower, 12 Wind, and 5 Crocodile, but by the culture hero 9 Wind Ehecatl-Quetzalcoatl and other priests who appear throughout the codices. Priests in the codices appear in black-and-white or grayand-white garments. Often, their shirt-like xicollis are decorated with greca motifs or white flowers. (15) Priests also wear black facial and body paint. Many wear a skeletal jaw or mask. These forms of symbolic imagery doubtless supported their roles as holymen specifically involved with the worship of the dead and the maintenance of the ancestor cult. 
The council works in groups of four.

They perform auto-sacrifice before sacred bundles dzutu sandidzo ñuhu:

"priests who carry the nuhu"
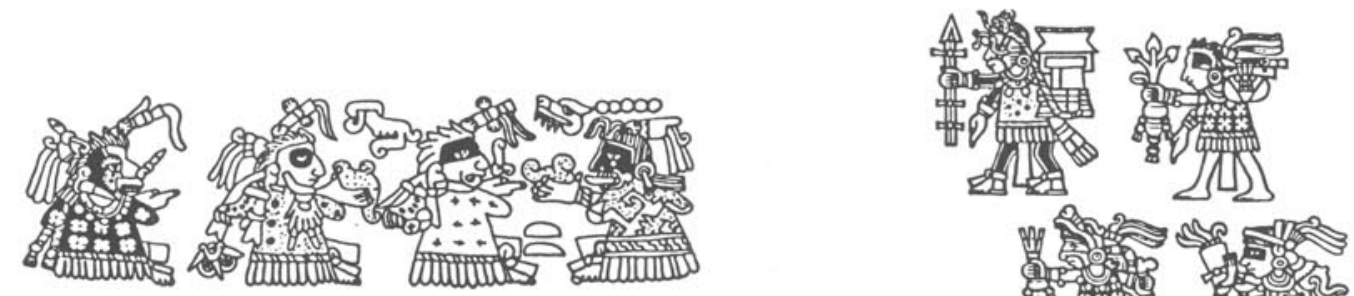
1 留

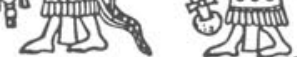
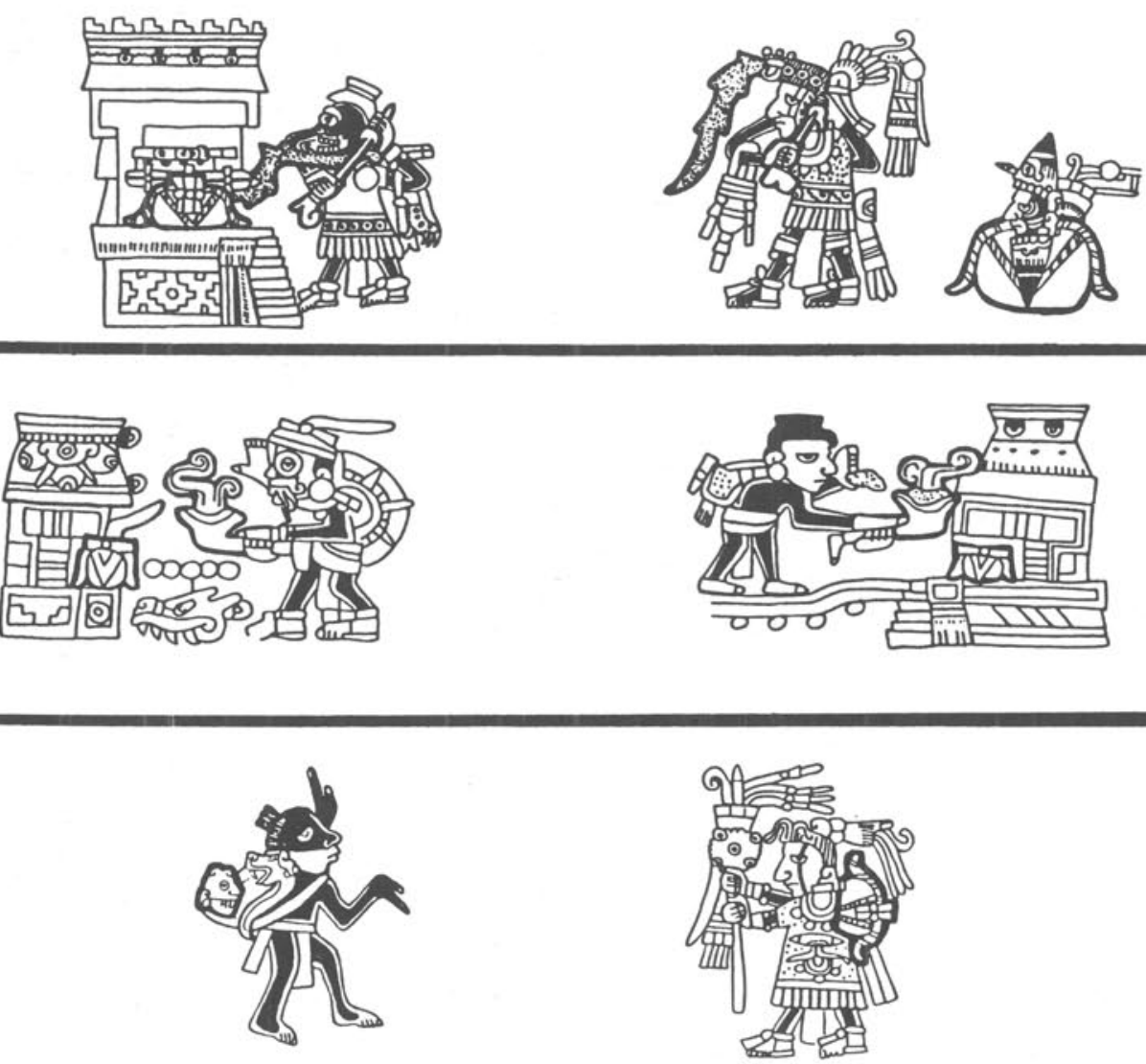

CHART 1

BEHAVIORAL CHARACTERISTICS OF THE COUNCIL OF PRIESTS 
Just as their costume is characteristic of their rank and position, so is their behavior. Priests appear in foundation myths in which they transport the sacred bundles and regalia of rulership from a Place of Heaven to several different kingdoms. They are the personages most closely associated with the $\tilde{n} u \mathrm{hu}$ bundles, before which they are seen either burning incense or making auto-sacrifices. There is virtually no case in the codices in which the "king" himself physically handles a sacred bundle. The Codex Selden scenes in which many of the rulers of Jaltepec appear before the Temple of the $\tilde{n} u h u$ at Jaltepec and burn incense before a sacred bundle conform with Herrera's (1945) statement that before acceding to the throne, some Mixtec kings were required to spend a year serving as a priest.

It is clear that more than one bureaucratic organization, the paramountcy of kingship, is being portrayed in the codices. The four priests discussed here specifically conform to descriptions in the Relación de Tilantongo and elsewhere of a body of judges who administered the realm for the king. The head of this council was also the war leader.

Further evidence for the political roles of priests as pictorialized in the codices, is found in the accounts of the 1544-1546 Inquisition of Yanhuitlan. When the Dominicans brought the "gobernadores" (governors) Don Domingo, Don Francisco, and Don Juan to trial, numerous witnesses testified as to the kinds of behavior in which the defendants were involved. While Don Domingo was acting as regent/cacique, Don Francisco supervised four priests who took care of twenty sacred bundles containing idols for Don Domingo. The four priests, clearly equivalents to the "regidores" described for Tilantongo, were accused of making blood offerings to idols and burning copal just as did the holymen in the codices. According to one of these native priests, also named Domingo, the idols were later seized by the encomendero Francisco de las Casas when Don Francisco was arrested. This event suggests that the accusations of idolatry were in some way connected to a power play on the part of de las Casas. (Spores 1967: 230-231, Greenleaf 1969).

The role of Don Domingo bears resemblance to the behavior of his distant ancestor Priest 5 Crocodile as well. As brother to Doña Maria de Coquahu, Don Domingo was not in line to become cacique of Yanhuitlan (Spores 1967: 135). Consequently, he had been educated as a native priest, like Don Francisco and Don Juan. When the rightful heir to Yanhuitlan (Doña Maria's son, Gabriel) was deemed to young to inherit on his mother's death, Don Domingo served as a stake-holder in Yanhuitlan, perhaps in much the same way as 5 Crocodile had at Tilantongo.

To summarize, this discussion of the role of kinship as a means of defining a social hierarchy focused on the traditional selection of an heir by rules of birth right in order to preserve the sanctity of the royal line. I emphasized primogeniture because it was the "preferred" system by the Mixtec. However, even a political system founded on phenomena so basic as marriage and the production of offspring can become upset if a viable heir is not produced. A perfect example is the tragic fate of Lord 2 Rain Ocoñaña of Tilantongo. For this reason, good administrations maintain alternative systems of ensuring that the economic and social fabric are preserved, despite problems in the transference of royal authority. The 
question is where to place that administrative safeguard within the hierarchy.

In his discussion of the mechanisms of succession, Jack Goody emphasized the need for stake-holders during an interregnum. From comparisons of several traditional societies, he proposed that such officials are most effectively recruited from among the priesthood, for they are the caretakers of the emblems of sacred authority so important to both popular religion and kingship. They are ideally suited because they may be members of the royal line with a vested interest in the maintenance of social order yet, because of their membership in junior descent groups, lack strong claims to the paramount position themselves.

Mixtec priests, both in powers described in Colonial sources and in their activities portrayed in codices, precisely fit the the roles of stake-holders in a system of governmental checks and balances. They were members of the upper class often shown with little or no genealogical background in the codices, in striking contrast to the extensive inheritance lists given for kings. We may perceive analogues for such authority in the management of bundles by medicine men in Blackfeet social organization for example. Pronounced similarities in theology are sufficient to suggest a common origin for Blackfoot and Mixtec bundle cults. (16). This could either be traced back to the Archaic roots of native religion or to an emulation (though probably not direct) of certain forms of ritualism by either the Blackfeet or the Mixtec at a later time.

Admittedly, both cultures have experienced significant changes in social organization concomitant with various environmental adaptations. Nevertheless, by functional comparison alone, we may glimpse something of the processes that may have led to the development of Mixtec religion and aristocratic history. For example, obvious differences in the contents of the bundles are indicative of the concerns of the people who used them. The Blackfeet beaver bundle, a symbol of tribal unity, contained the pelts of animals that represented not only the principal spirit powers but game animals exploited by tribal hunters. Mixtec bundles on the other hand were imbued with the spirit powers of rain, corn, and the earth, reflecting uniquely agrarian concerns.

Both cults are reflective of two differing exploitation strategies associated with the tribal organization of hunters and gatherers on one hand, and the chiefly organization of settled villages on the other. Marked differences appear in control over the bundles. Among the Blackfeet, the beaver bundle is given to a member of the tribe based upon the individual's predilection to the spiritualism with which a bundle is associated, regardless of clan affiliation. Possession of a Blackfeet beaver bundle is a means of physically displaying one's status as the possessor of critical elements of tribal history and legends, including songs that recount geographical locations critical to a seasonal hunting strategy (Reeves 1993).

By comparison, the Mixtec usage of the bundle not only as a symbol of community identity, but also as the focus of a royal ancestor cult, implies that, at some point, control over critical information had passed into the hands of a single kinship group. This could have happened by direct seizure during a formative period, when one clan came to dominate the 
society (militarily), or perhaps through some later form of religious specialization, when the ability to learn songs and perform acts associated with the bundle became the task of a single descent group (charismatically). The fact that the chief Mixtec bundle priest was a relative of the king, head of the war council, and a specialized religious practitioner by the Postclassic period points to a combination of all three factors.

At the tribal level, sacred bundles may symbolize social unity or define special roles through membership in "societies." The most sacred bundles however are not imbued with the power of an individual or even specific ancestors, but rather with more generalized culture heroes or spirits invoked from an overall tribal history or environmental animism. At some point, Mixtec social order symbolized in such beliefs became fused with the establishment of a paramount position no longer dependent upon election by tribal consent. Early Mixtec chiefs no doubt discovered that the most effective means of symbolically consolidating their authority was to infuse their personal ancestral history into that of the group (i.e., $\tilde{n} u h u$ as both deceased king and the spirit force of the environment).

This contributed to what Goldman described as a "Stratified" level of social organization in which the paramount and his ancestors are thereby deemed divine. The act is a form of seizure on the part of a powerful kin group; an appropriation of a society's overall religious history on the part of ambitious individuals who seek to fix the most authoritative positions within their family and to preserve this power through descent.

In order to stress the sanctity of a royal line the paramount would by necessity depend upon relatives who were the caretakers of sacred bundles in order to focus popular attention on the cult of the individual. This process is nowhere more evident than in the codices. It is not the kings themselves who descend from "Heaven" on rope ladders bringing the holy regalia of rulership, but rather the four priests led by such culture heroes as 5 Flower and 12 Wind. Likewise, Lord 8 Deer seeks the support of his brother 9 Flower as his chief priest and keeper of the sacred bundle in his bid to usurp the throne of Tilantongo. 


\section{THE YAHA YAHUI}

The identification of four councilor priests who played a significant role in the corporate management of Postclassic Mixtec kingdoms was proposed in Chapter II through a contextual analysis of costume and behavior in the codices. Conclusions drawn from the pictorial sources were then compared to Spanish descriptions of priests, often four in particular, who served as royal councilors, judges, regents, and stake-holders. Their position was rooted in their control of idols wrapped in sacred bundles, which represented not only the focus of popular religious worship but also the regalia of rulership.

Analysis of documents pertaining to the 1544-1546 Inquisition of Yanhuitlan further indicated that the accused, Don Domingo, Don Francisco, and Don Juan, represented more than simply three wayward idolators caught up in the dragnet of religious persecution; rather their behavior suggested that they were operating as the articulated parts of a governmental bureaucracy. Such behavior was not only religious in context but equated with the display of power in political ceremonialism.

If the behavior of Don Domingo, Don Francisco, and Don Juan reflects the survival of a Pre-Conquest administrative system at Yanhuitlan, then a further dichotomy in roles apparently existed between "gobernadores" as well. Don Francisco was accused of supervising the bundle cult together with four priests. The bundles contained twenty idols that were given names such as guacusachi, quaquxio, quaquxiq, and so on (Jiménez Moreno and Mateos Higuera 1940: 48). All of these names are calendrical and seem to refer to deified ancestors. guacusachi for instance means the "idol" (guacu/quacu) "7 Wind" (sachi) (Jansen 1982: 284, Smith 1973a: 24-27). 7 Wind appears as one of the heroes of the War of Heaven in Zouche-Nuttall 3 B-C (See Rabin 1979). Other identifiable names represent personages appearing in both ZoucheNuttall and Vindobonensis. Don Francisco and the four priests were accused of making offerings of tobacco, copal, and quail to these idols and performing auto-sacrifice (Jiménez-Moreno and Mateos Higuera 1940; 38-39).

Don Juan, on the other hand was accused more specifically of committing human sacrifices (Spores 1967: 26) and of preaching to the people to worship four gods named caagui (dzavui), ticono, toyna, and xitondocio (Jiménez Moreno and Mateos Higuera 1940: 38, Spores 1967: 2526). The latter are not calendrical names but rather titles for more generalized concepts of deity. Dzahui for instance means "rain." Clearly, Don Juan differed in his activities from Don Francisco. In this chapter we will explore the roles of those charged with human sacrifice, a second order of priests called yaha yahui. 
On the left hand portion of Zouche-Nuttall 19, a figure appears to be flying through a rocky matrix (Fig. 14). It wears a fire serpent headdress, a tortoise shell over the body, and has claws that grasp sacrificial knives. In the course of studying personal names in the Codices Egerton and Muro, Smith (1973b) recognized personages who could be identified either by the wearing of a fire serpent headdress alone or by the full configuration of headdress and tortoise shell. These personages were glossed as yaui or yahui (yavui).

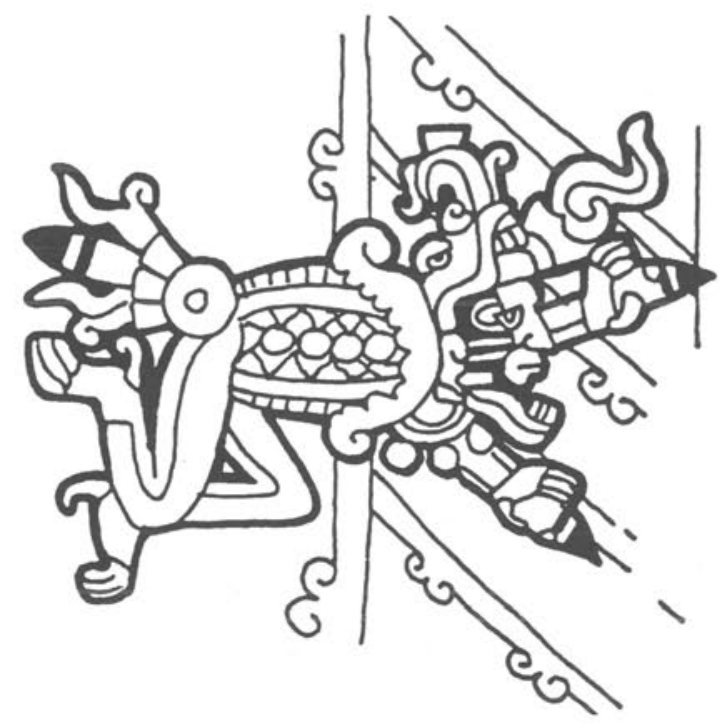

Figure 14: Yahui wizard holding sacrificial knives flies into or through a cliff (ZoucheNuttall 19)

The Alvarado dictionary (1962: 122B) lists one of the meanings associated with this term as "hechizero, otro embaidor que por los ayres bolava," or "a witch or wizard, another impersonator who flew through the air" (Smith 1973b:63). The term seems to fit the portrayal of the flying figure on Zouche-Nuttall 19. The Alvarado dictionary also lists the term yaha yahui for this "impersonator". Yaha means "eagle," and it is noteworthy that the yahui figure is often paired with an eagle (for instance, Selden 12 II and Zouche-Nuttall 69) (Fig. 15).

Although the yahui personage makes relatively few appearances in the pictorials, there are several significant scenes that relate to his functions. Codex Vindobonensis 48 portrays the Mixtec culture hero 9 Wind Ehecatl Quetzalcoatl's descent to earth bearing regalia associated with royal authority in much the same way as Priest 12 Wind in Zouche- 

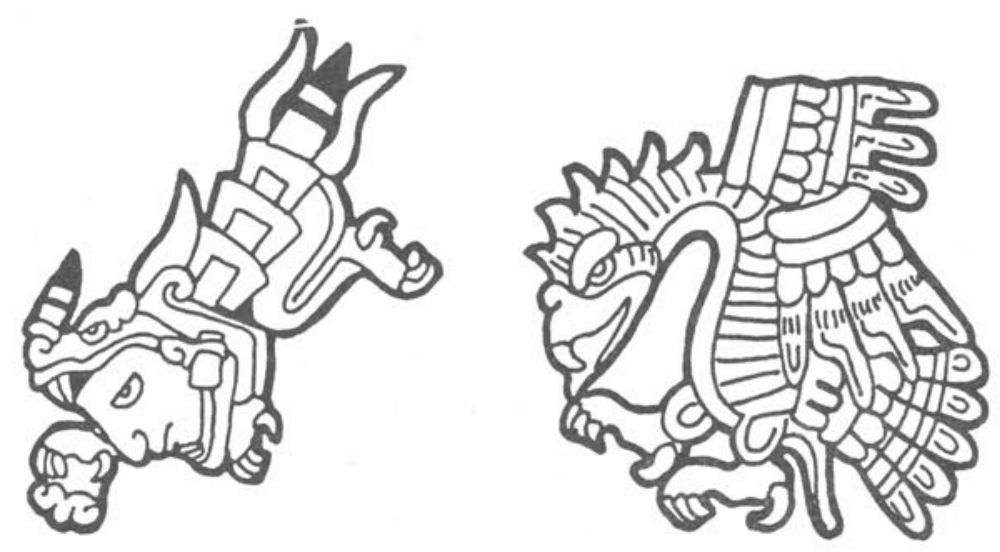

Figure 15: A yahui flies while clutching a human heart. His cohort is the eagle or yaha.

Nuttall. He is accompanied by two flying figures, one in an eagle costume and the other in the fire-serpent costume. The eagle figure bears a sun temple on his back, while the fire serpent bears a temple dedicated to a Mixtec fusion of the Flayed god and the rain god called 7 Rain (See Pohl and Byland n.d.a.). The yaha and yahui figures are therefore involved in the foundation of Mixtec kingdoms, much like their fellow ministers, the four priests.

It is notable that the two temples are dedicated to the sun and to a deity with pronounced sacrificial and rain attributes, much like the gods which Don Juan was accused of patronizing in the Yanhuitlan idolatry trials. Selden 12 II shows the yahui and yaha offering hearts and blood to the solar deity. It seems plausible, therefore, that the yahui figure bears connotations of sacrifice, rain and sun, fundamental symbolism in Mesoamerican religious ideology. Chart 2 outlines the behavior most commonly associated with these personages in the codices.

Caso $(1964: 27,75)$ first suggested that the yahui figure might have been a specialized role for sacrificers in a Mixtec priestly hierarchy. A similar observation was made by Smith (1973b). Nicholson (Nicholson and Quiñones Keber 1983:176-177) found support for the hypothesis in proposing that the hafts of surviving sacrificial knives found in the Museo Naziole Preistorico-Etnografico Luigi Pigorini in Rome and in the British Museum, London, represent the yahui and the yaha sacrificers, respectively (Fig. 16a and b). Indeed, the "flying" pose displayed by the figure on Zouche-Nuttall 19 conforms with that of the eagle and fire-serpent figures on the hafts of the knives.

Stories of wizards who fly around the canyons of the Mixteca Alta abound in the Mixtec folkloric tradition today. Jansen 1982a) reports stories of the yahui (or yahua) which persist in Apoala. The yahui is viewed as both a witch who can pass through solid rock and as luminescent balls that fly across the valley at night. One of the entries for yahui, combined with the term nduvua, in the Arana-Swadesh dictionary (1965: 133) is "comet". It seems that the luminescent balls described as yahui by the Apoala Mixtec are also shooting stars. 

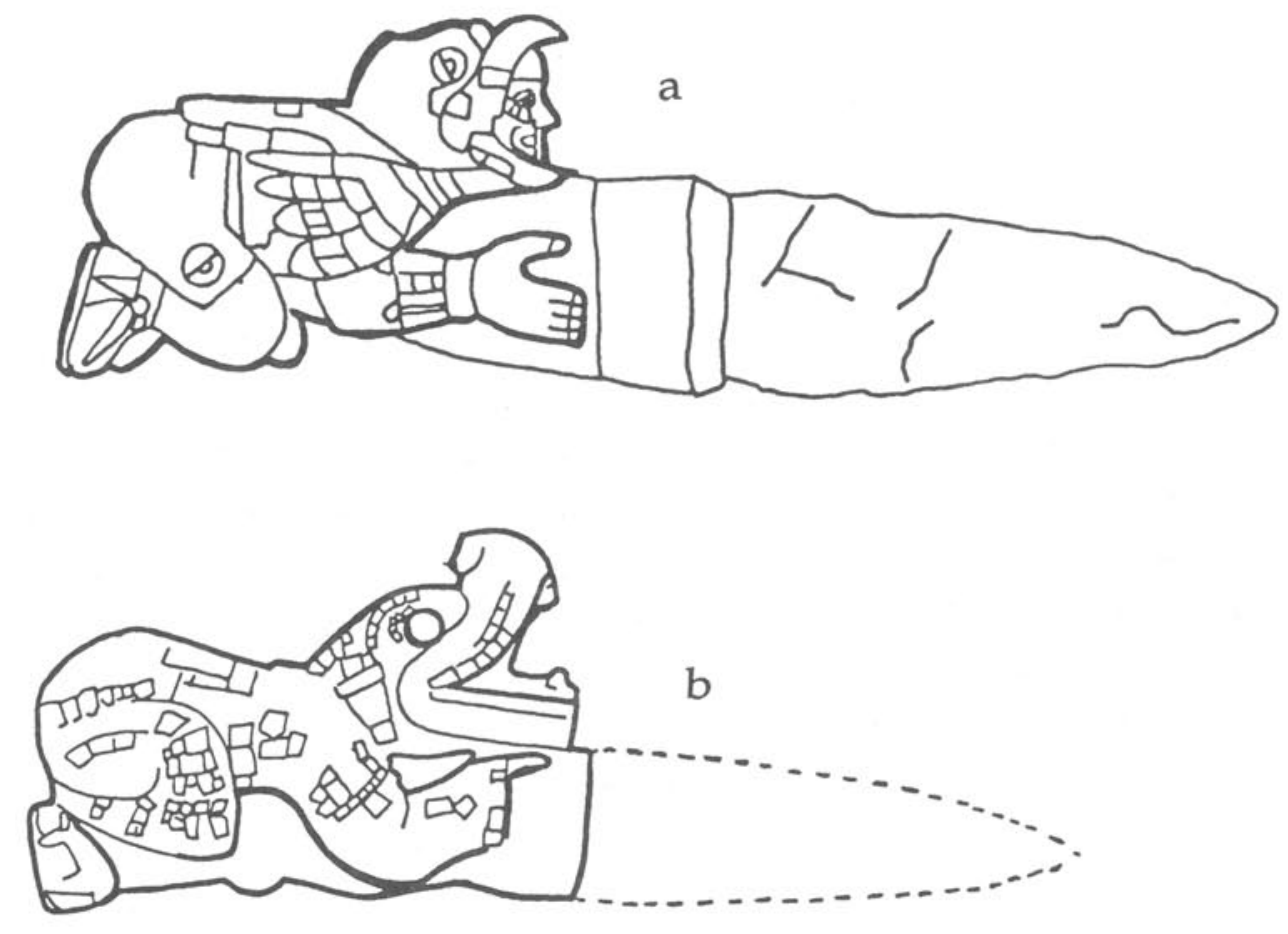

Fig. 16: Sacrificial knives (See Nicholson 1983: 176-177 for discussion). The Mixtec word for these knives is yuchindaha. Yuchi means "flint" while ndaha might refer not only to a human hand ("hand flint") but also to tribute ("tribute flint"). (a) Yaha or eagle impersonator, British Museum. (b) Yahui or fire serpent impersonator, Museo Nazionale Preistorico-Etnografico Luigi Pigorini, Rome.

Monaghan (n.d.a.) reports stories from Nuyoo of a yahui supernatural called the ndoso who flies about the sky like a lantern.

The ability of hechizeros or wizards not only to fly but to prophesize is commonly attributed to the ingestion of mushrooms and other hallucinogens, enabling them to transform themselves and to fly to the ancestors, thereby receiving answers to their questions or even diagnosing disease (Ravicz 1961). The Huichol, for instance, believe that they are transformed into birds for a 300-mile pilgrimage to a sacred homeland, "the birthplace of the gods," where peyote is collected (Myerhoff 1974, Furst 1972). The hallucinatory perception of flying while 
while experiencing mushrooms has been noted by Gordon Wasson (1980: 47), citing fieldwork by Henry Munn:

"...(the curandero) has a sense of flight through the air... many feel as though they are rushing through the air, riding a great bird with wide wings...looking down on the earth far below."

The effects of mushrooms were likewise related by the Mazatec curandera Maria Sabina, who addressed herself as "the Primordial Eagle" during trances induced by mushrooms (Wasson 1980:47). The mushroom itself is considered to be a supernatural being with whom the hechizero speaks in order to obtain information and to learn the future (Motolinía 1951: 96). Tellingly, Maria Sabina addressed the mushroom as Jesus Christ (Wasson et al 1974: xxiv). "The Word," or communication from the gods, falls onto the practioner as little balls of light, an attribute of the yahui (Wasson 1980: 13). In the Inqusition of Yanhuitlan, Don Juan was accused of taking mushrooms in order to invoke the devil and to speak with the ancestors (Jiménez Moreno and Mateos Higuera 1940: 38).

The term yahui can have a variety of meanings. A cave, for instance, is yavui cavua or "yahui cliff" in Mixtec (Alvarado 1962: 59). The words correlate with the place sign on Zouche-Nuttall 19, in which the yahui is shown passing through the solid rocky matrix of a cliff, designated by striated lines of varying colors. In the course of survey in the Tilantongo area, a burial cave was identified that appears to be the location signified by the yahui glyphic configuration depicted in Zouche-Nuttall 19 (see Pohl and Byland 1990). The cave is located below a rancho called Huachino or Juanchino, the ranch of Juan the Chino. It is called the Cave of the Angel or Cave of Sickness, but it is also said to be the home of a devil where people from Jaltepec go to be cured of disease and to ask for money.

Ron Spores (personal communication) has recorded stories of a "catrín" or devil in the canyon below the cave. In one account the devil is dressed as a Spanish don and rides a white horse. If one descends into the canyon and waits, the devil will magically appear on his horse and grant money in exchange for one's soul. The association of a burial cave with a devil relates to another meaning for yaha yavui as "nigromantico senor," or a lord who divines with the dead (de los Reyes 1976:79).

Behavioral characteristics of the yaha yahui figures in the codices correlate with both folkloric descriptions and linguistic terminology indicating that the Mixtec priesthood also included a group of diviners or prophets whose specialized role was to make human sacrifices, and to conjure with the spirits of the dead in much the same way as brujos and hechizeros throughout Oaxaca today. The yaha yahui is associated particularly with the worship of the dead in caves.

Caves were known to be the repositories of the mummified remains of dead nobility. Herrera (1945: 169) said that when the kings died they were taken by the four priests for burial 
in caves in the surrounding mountains. Burgoa (1934 I: 338-339, 372) similarly describes a great cave at Chalcatongo in which the kings of Tilantongo were buried. A Mixtec word for "tomb" is yavui nafta (Alvarado 1962: 188B). Clearly, an important aspect of Mixtec religious life was not only the worship of ancestors through the sacred bundles kept in the civic-ceremonial center, but also the veneration of the dead themselves who were located in various shrines throughout the natural environment. The Relación de Mitlantongo (Acuña 1984: 238) speaks of "hidden" locations in the highest hills on Mitlantongo's boundaries, where priests worshiped the sun and idols of precious stone and gold. Priests made human sacrifices of men and children in these places, invoking the devil who appeared to them as an apparition and spoke to them. The place sign for Mitlantongo in the Codex Mendoza (Smith 1973a: 78) even includes a mummy bundle as a principal qualifier.

\section{CASE STUDIES}

LORDS 8 WIND, 8 DEER, AND 4 WIND AS YAHA YAHUI

Three prominent lords appear as yaha yahui impersonators in the codices. ZoucheNuttall 1-2 depicts the appearance of the deity ancestor, 8 Wind "Flint Eagle" (See Furst 1978b). 8 Wind first emerges magically from four place signs. These include Apoala and Hill of the Monkey (Cerro Jasmin-Suchixtlan) (Byland and Pohl: in press). On page 2A, Lord 8 Wind is dressed in a complete eagle outfit as a yaha and stepping out of a crevice at the site of Yucuñudahui (Jansen 1982a: 268-270) (Fig.17).

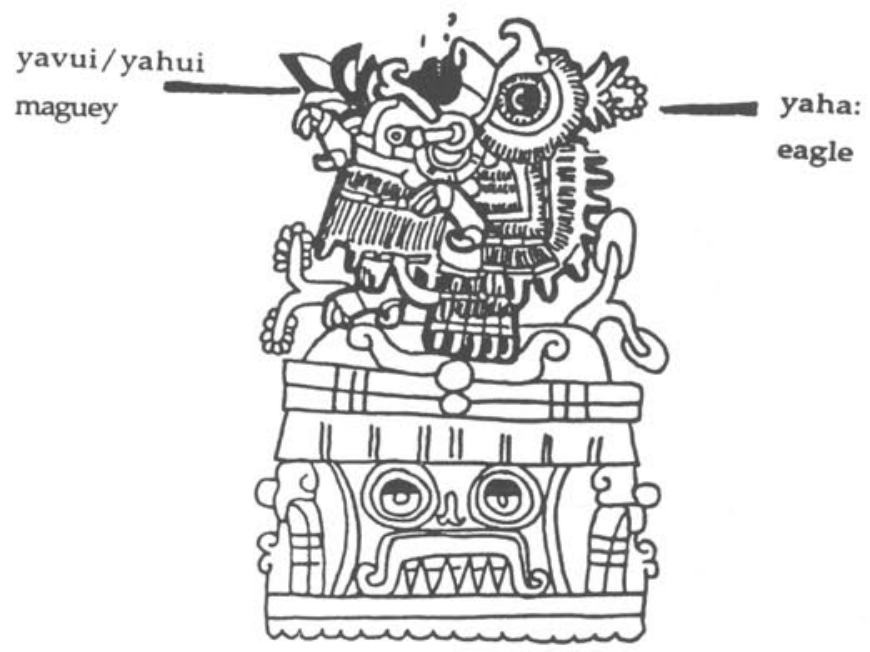

Figure 17: The yaha-yahui or wizard 8 Wind emerges from a cave at Yucunudahui. (ZoucheNuttall 2). 
Attached to his eagle outfit are maguey plants. The term for maguey is yavui (Arana and Swadesh 1965: 133), a variant of yahui as "hechizero." John Monaghan (n.d.a. 607) recorded legends of the yahui or yawi in Nuyoo. In one account a woman was molested by a Yawi who took the form of a kinsman. The woman noticed its clawed feet however and threw boiling water on the spirit. The next day she saw a burnt maguey plant and recognized it as the Yawi she had encountered.

8 Wind, therefore, wears garb that is qualified with symbols for the title yaha yahui. Significantly, he is shown emerging from openings in the earth that represent caves. Following an account of the War of Heaven (Rabin 1979) on Zouche-Nuttall 3-4, 8 Wind next makes his appearance on page 5A. Again he emerges out of the earth or caves at two new locations while wearing the yaha eagle garb. He is subsequently "baptised" by the rain god, dzahui (Byland and Pohl n.d.). Jansen (1990) has noted that bathing in rain water was a means by which Mixtec curanderos transform themselves into spirits, especially serpents. Directly after the baptism, 8 Wind appears as a "normal" person no longer possessing clawed feet. He founds the community of Hill of the Monkey and marries Lady 10 Deer, producing children who in turn marry with the royal lines of Jaltepec and Tilantongo. Finally, 8 Wind makes his last appearance on page 7 of Zouche-Nuttall. Here, over 80 years old, he is addressing his great-great-grandson, the ill-fated 2 Rain Ocoñana of Tilantongo.

Lord 8 Deer appears in Codex Zouche-Nuttall reverse as the yaha on page 44B (Fig. 18). Here he is part of a sequence of people who meet with the goddess 9 Grass who is seated in her Skull Temple at Chalcatongo. The first figure is a deceased lord named 3 Lizard, "Flint Band" (Fig. 2a). He is dressed in the garb of a yahui priest with fire serpent headdress and a tortoise shell covering the body. Above him sits the Lady 6 Monkey of Jaltepec, followed by 8 Deer wearing the eagle headdress.

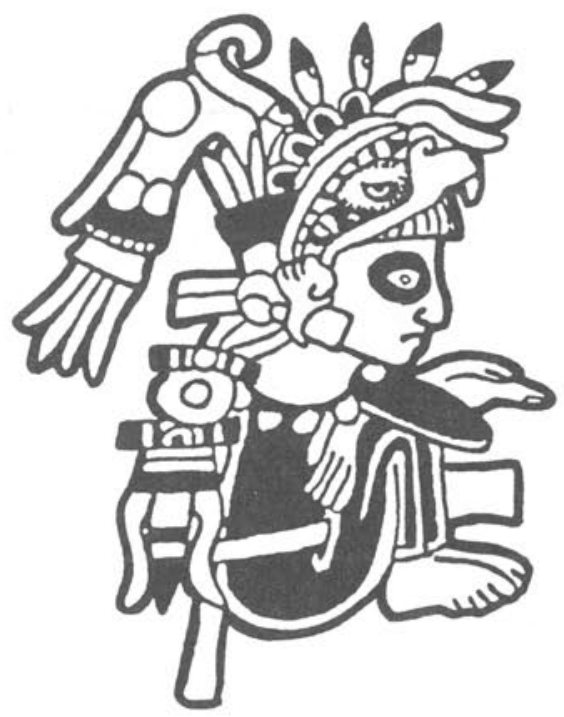

Figure 18: Lord 8 Deer as yaha (Zouche-Nuttall 44). 
The scene is cognate with Colombino 4 II (Troike n.d.b.: 132-136). 8 Deer appears before the Lady 9 Grass, from whom he receives precious gifts. A sequence of six personages is given. The second is 3 Lizard "Flint Band," this time dressed as not the yahui but the yaha. Behind him sit two other dead men. The first is wearing the yahui outfit and the second, named 4 Grass, wears the yaha suit like 3 Lizard. Lord 4 Grass appears again in Becker 2 III as a resurrected warrior who is able to do combat in spite of the fact that he had been sacrificed (Troike n.d.b.: 136). On Zouche-Nuttall 50, 8 Deer appears before a second goddess named 9 Reed. This time he is dressed as the yahui, wearing both the fire serpent headdress and the tortoise shell. After serving as a yaha yahui, 8 Deer eventually embarked on a military career, which led him to usurp Tilantongo after the death of 2 Rain and to start the second dynasty at the site (See Caso 1960, 1966; Troike n.d.b.).

The last great yaha yahui to appear prominently in codical history is 8 Deer's future son-in-law, Lord 4 Wind. Lady 6 Monkey of Jaltepec married Lord 11 Wind of Red-and-White Bundle. They had a child named 4 Wind "yahui" (See Selden 8IV). Although 8 Deer attacked Red-and-White Bundle and killed both 6 Monkey and 11 Wind (along with two sons of 11 Wind by a previous marriage), 4 Wind "yahui" was spared. On Zouche-Nuttall 83, 8 Deer captures 4 Wind, grasping his hair while holding a spear-thrower menacingly. Nevertheless, on Bodley 33-34 V, 4 Wind appears not as 8 Deer's enemy, but rather as the yahui receiving 8 Deer's captives, 10 Dog and 6 House, Lord 11 Wind's children from his first marriage. 4 Wind sits inside a cave which is qualified by a yahui place sign, probably the funerary cave located near Jaltepec and discussed above (Fig. 19).

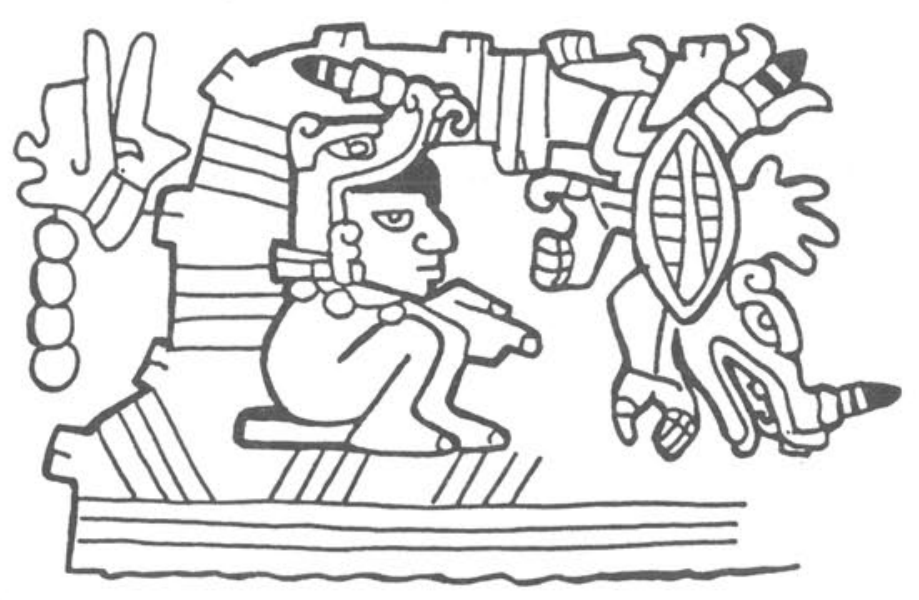

Figure 19: Lord 4 Wind as yahui at the cave or cliff of the yahui (Codex Bodley 33V) . 
They are credited with the ability to fly

through the heavens or move through the earth.

They perform human sacrifices.

잉

They are associated with markets, stores, and caves.

Title is associated with persons who later become dynastic founders.
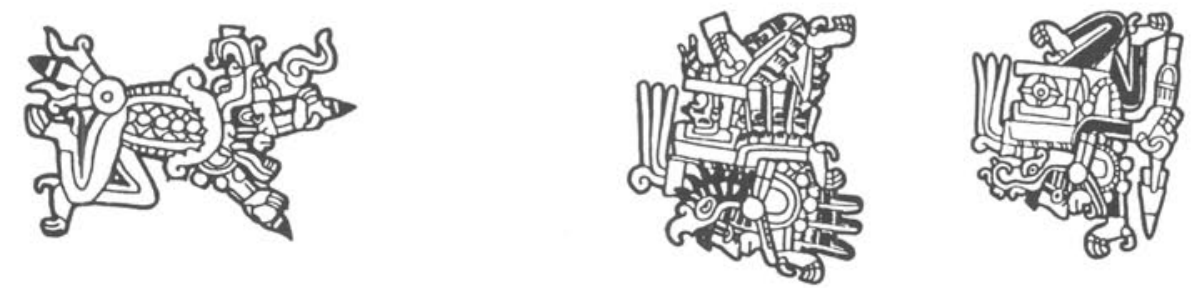
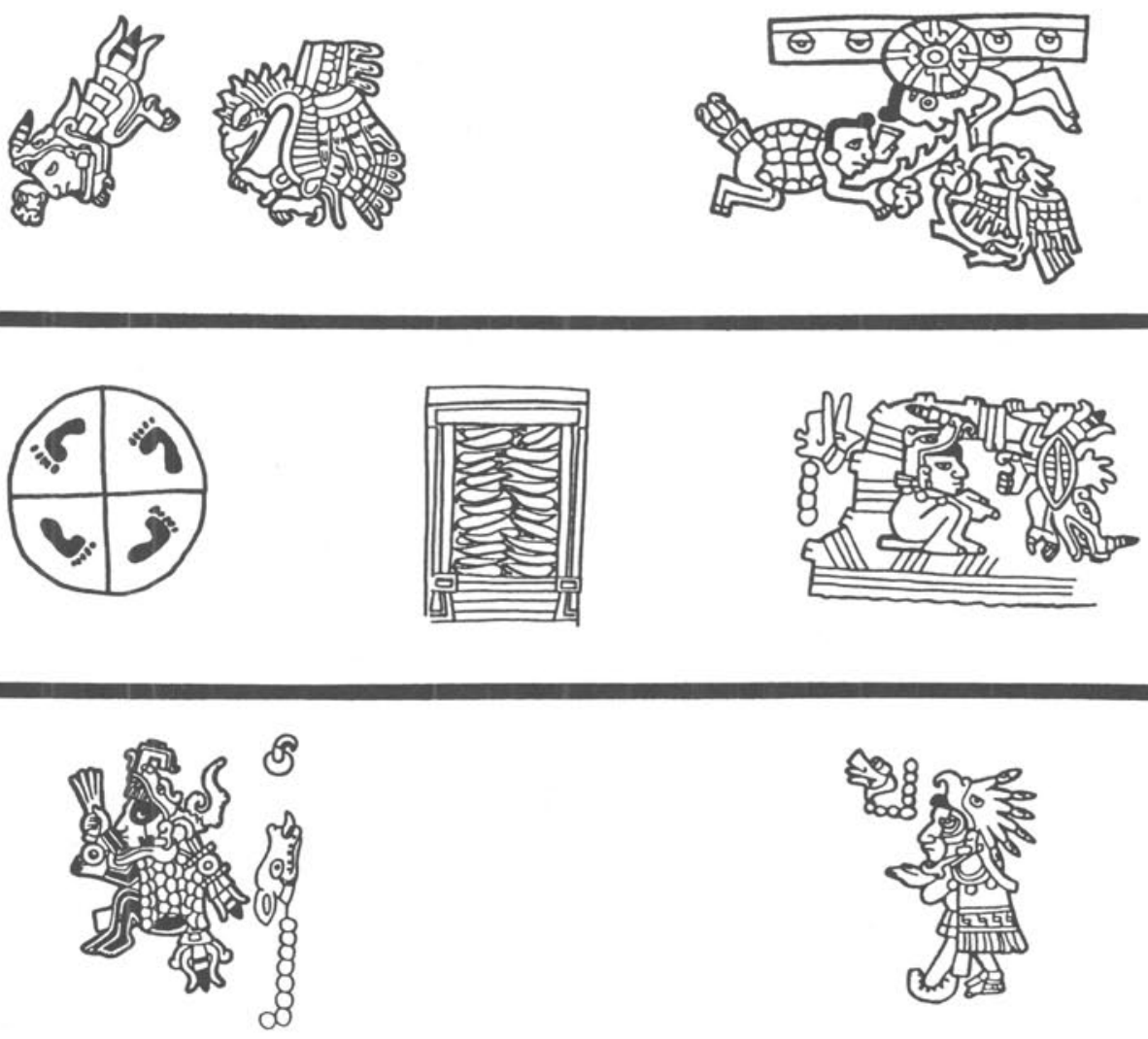

CHART 2

BEHAVIORAL CHARACTERISTICS

OF THE YAHA YAHUI 
The fate of 10 Dog and 6 House is shown on Zouche-Nuttall 83-84. They were sacrificed by execution on a scaffold and by gladiatorial combat with jaguar impersonators. The Bodley 33$34 \mathrm{~V}$ scene implies that 4 Wind was directly involved with the act. In interpreting these appearances, Nancy Troike has proposed that 4 Wind was also responsible for 8 Deer's assassination (Troike n.d.b.: 369-379). Codex Bodley 32-29 describes 4 Wind's rise to power, his foundation of a new dynasty at Place of Flints, and his marriage to 8 Deer's daughter, 10 Flower.

To summarize, the majority of appearances of the yaha yahui in the codices involve their supernatural abilities of flight and human sacrifice (Chart 2). Three lords appear who at one time in their lives served as the yaha yahui. The great patriarch 8 Wind "Flint Eagle" was a yaha yahui who emerged from the earth to start a dynasty at Hill of the Monkey. He was blessed with the ability of transformation by the rain deity dzahui himself. 8 Deer, on the other hand, may have been elected to the position and represented one of several yaha yahui. Remembering that his father 5 Crocodile, was head of the council of four priests at Tilantongo, 8 Deer's succession to the position is not surprising. Like Lord 8 Wind, 8 Deer also became the founder of a dynasty at Tilantongo. Finally, we examined Lord 4 Wind, who apparently bore the title "yahui" as a personal name as well as served in the capacity of sacrificer and diviner. Significantly, 4 Wind also became the founder of a new dynasty at Place of Flints. Burgoa (1934 I: 289) described special "lineages" of astrologers and diviners. It would appear that the yaha yahui could, in fact, not only marry and produce heirs during their priestly tenure but given the failure of a royal line, they could select a replacement for the paramount from among the yaha yahui priests.

\section{SACRIFICE AND THE MANAGEMENT OF ECONOMY}

The term "yahui" bears other significant meanings in the Mixtec language. Smith (1973b: 49) noted that yahui not only refers to a hechizero and his role as sacrificer, but also to economic terms such as "market", "salary", "price", "gain", and "expensive". This suggests that the yaha yahui might have played a role in the administration of economy as well. The term for a sacrificial knife used by the yaha yahui was yuchi ndaha (Alvarado 1962: 154b). Yuchi means "flint". Ndaha means not only "hand", "finger", "arm", but also "tribute" paid to a king. The possible fusion of economic terminology with human sacrifice and divination is curious to western ideology. On the other hand, John Monaghan (n.d.a., n.d.b.) has suggested that economy and sacrifice have much in common in traditional Mixtec thought.

Monaghan has proposed that most forms of economic exchange in the community of Nuyoo are rooted in a paradigm of sacrifice. The origin of this perception lies in two creation stories called "The Covenant with the Earth" and "The Covenant with the Rain" (Monaghan 1990b). In the first story, two men labored hard to clear the earth for planting, but their work 
was always overgrown the following day, and they had to start over again. Frustrated, the men prayed to the earth ( $\tilde{u} u \mathrm{hu}$ ) asking it to provide for them. In exchange, the men promised that they would give themselves to the earth when they died. This story has much in common with Gregorio García's legend of the twin brothers named 9 Wind who created the present world and who appear in Codex Vindobonensis as the yaha and yahui (see Smith 1973b and Jansen 1982: 148-149 for discussion).

In the second story, there was no rain on earth. The plants, animals, and men all conferred with the spirit of a rock lying in a marsh called Mayor San Marcos. The rock produced the first clouds, which brought forth the rain. When Monaghan asked Nuyootecos for explanations, they said that the stories were about why they have to die, which is to say why they are "eaten" by the earth. Nuyootecos view themselves as only living through the sacrifice of the earth to provide food. In exchange, they must sacrifice themselves to the earth when they die.

The sacrificial paradigm becomes most apparent in the collection of material and finances by Mixtec mayordomos for the annual festivals of the patron saints. In Jaltepec, this is done by carrying a large crucifix around to the various agencias (outlying villages), stopping people who are traveling along the roads and collecting money placed in a small coffer bearing an image of a saint. Cash is also raised through the contributions of those doing work in Northern California. One American community is even considered to be an official agencia of Jaltepec. In Nuyoo, mayordomos have two general means of raising money (Monaghan n.d.b.). The first is money given to the saint in soko or dzoco which is to say "sacrifice" by members of the community. The other is made up of money earned by investing the mayordomo fund, cash serving as principal that comes as part of the cargo of office.

Monaghan (n.d.b.: 4-7) found that soko is collected when the mayordomo and his assistants carry the image of a saint called ito' 0 from house to house in the community. There are actually three saints that are taken on the perigrination: Misercordia, Santo Entierro, and Santa Cruz. Note that they are all connected thematically with the crucifixion, the supreme sacrifice of the lord. When one of the saints arrives at a household, the image is set upon an altar and family members pray to the saint for the success of their crops and overall prosperity. Along with the prayers, soko, or sacrifice is given to the saint in the form of agricultural products such as squash, coffee, beans, eggs, chickens, fruit, and pulque, liquor and cash. The accumulation of goods through soko also becomes the most important means the community has for financing collective activity. Soko which is not used to finance the saint's festival is then added to the community fund for building programs, judicial fees, school finances, and so forth.

The large amount of produce collected by the mayordomos is also transformed into cash by the sale of goods throughout the year. The mayordomo's home consequently functions as a store where people can go to purchase produce that they do not have access to through their own means of production. Until the 1930's, when the first market was built, the mayordomos were the chief source of redistribution in the Nuyoo economy. In addition both soko money and the money forming the principal that comes with the cargo can be loaned out at interest. 
Consequently, the mayordomo also serves as a kind of loan agent or bank.

Monaghan (n.d.b.) suggests that the Nuyoo mayordomo system through which money is collected as sacrifice has much in common with a Precolumbian tribute system. There are in fact several Aztec references to mayordomo-like practices (Durán 1971: 139, Motolonía 1950: 54). For example, the enactment of Aztec religious festivals was equated with "debt paying" (Sahagún 1950-1982). Monaghan proposes that some notion of payment to a Mixtec elite is preserved in the term applied to the saints in Nuyoo: ito'o. The term is probably derived from ii toho or "sacred prince" (Arana and Swadesh 1965: 91, 127), implying that soko or dzoco was originally associated with the collection of money and goods by the ruling family, which is to say tribute. The Relación de Tilantongo (Acuna 1984) states that in fact tribute was given to the king in the course of ten religious festivals held throughout the year. Many patron saints celebrated in festivals today are also still addressed as yya, the title for a Mixtec king (see also Alvarado 1962: 187).

Aside from the metaphor of sacrifice, other linguistic and folkloric evidence suggests that the yaha yahui priest held responsibility for the management of a royal economy and tribute collection. The word for a "store" for example is huahi yocuvui yahui or nu cuyahui (Alvarado 1962: 195b, Stark Cambell et al 1986: 92). How the yaha yahui may have functioned more specifically as economic administrators is not clear. Comparison with the roles of mayordomos would imply that they supervised tribute collection and served as institutionalized overseers of the stores. Even the terms yaha and yahui might apply to elite food commodities; yaha is also "chile" and yahui, as we have seen, can mean "maguey" (Fig 20). (17)

One problem is that the characteristics of Postclassic Oaxacan economies have been subject to some debate (see Pastor 1987, Monaghan n.d.b.). It is questionable, for example, whether true markets really existed in the Mixteca. The kingdom of Coixtlahauaca reputedly had a great market where merchants gathered from all over Mexico (Durán 1964: 118-121). Otherwise very little, if any, mention is made of markets in Oaxacan ethnohistorical sources. It seems that just as the commoners paid their depts to the elite during religious festivals, the lords in turn paid tribute to each other at prearranged times and locations. Burgoa (1934 I: $352-$ 353) speaks of a kind of fair or market that was held by order of the king of Tututepec at Putla, a neutral border zone between the two kingdoms. The kingdom of Achiutla then brought its tribute payment to the fair, allowing the king of Tututepec to select whatever was needed for his vassals.

Smith (1973a: 49) notes that place signs representing a "yahui" or "market" appear as names of boundaries in Colonial Mixtec maps and not as labels of community centers. These locations doubtless refer to "fairs" such as those held on the plain at Putla. Significantly, Byland (n.d. 363-368) reported an anomalous obsidian-processing area covering some 10 hectares that surrounded an otherwise unimpressive Postclassic occupation zone on the community border 

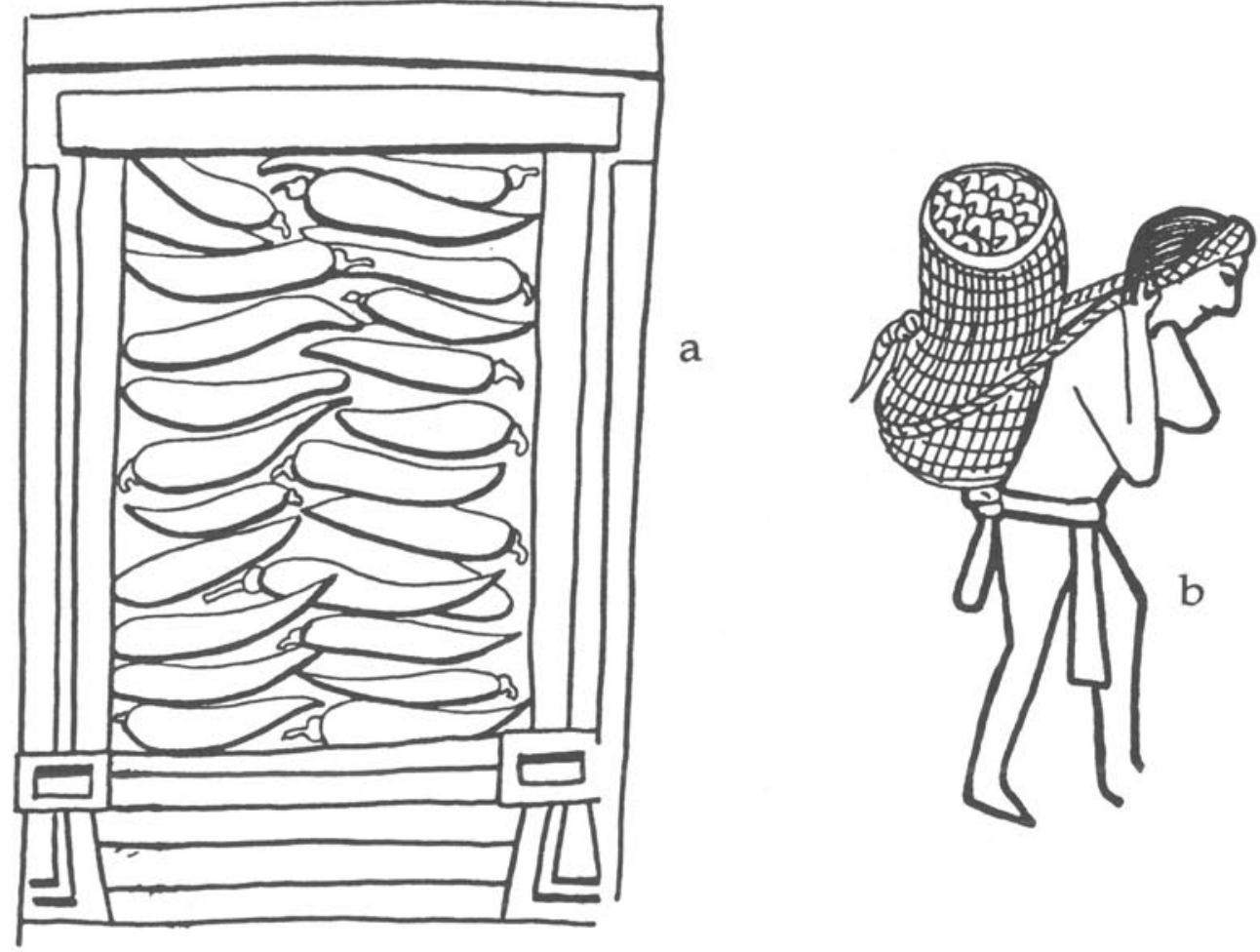

Figure 20: (a) Store house for chiles or yaha. (b) Commoner bearing tribute (Códice de Yanhuitlan).

between Tejupan and San Miguel Tulancingo, an agencia of Coixtlahuaca (See Chapter V). All of the obsidian had been transported onto the site, including a high proportion of the green Pachuca variety from the northern basin of Mexico. The location of such a large "processing" area within a marginal occupation zone suggests an artifactual manifestation of the kind of "market" that appears on Colonial maps as well. To quote Byland (n.d. 366): "The magnitude of this production center is unparalleled in Mesoamerica except for areas located on or adjacent to sources of raw material."

The holding of a market or the paying of tribute within non-aligned territory reflects concerns for regional security as well. One need look no further than the accounts of attacks on Aztec traders at Coixtlahuaca, Jaltepec, Huaxyacac, and Mitla to note the deadly outcome of "unfair" trading practices or tribute demands (See Hassig, 1988 for review). It appears that most economic exchanges were arranged through the tribute system and that religious festivals served both as the means by which tribute was paid and the means by which goods were circulated through a redistribution system.

The redistribution of tribute (or income from other forms of economic enterprise) and exotic materials obtained through trade were circulated throughout the society by direct control of the paramount. Edwina William's (n.d.) study of the distribution of Pachuca green obsidian from the Tilantongo Valley reveals that cores are found in abundance around the ruins 
of the Tilantongo royal palace and associated structures, but they are rarely found in the outlying sites. Green obsidian blades on the other hand, particularly those used for rituals of auto-sacrifice, are found only in the higher ranked sites of the princes and not in the sites occupied by commoners, who for the most part used local chert or black obsidian. The implication of Williams' observation is that the importation, processing, and distribution of Pachuca obsidian and, by extension, exotic goods in general was directed by a mayordomo-like agent operating within the royal precinct itself.

Perhaps the most compelling evidence for the economic role of the yaha yahui is found in Mixtec legends of spirits who own vast stores, magically appearing in caves or other openings in the earth. These accounts are very similar to those of the devil or catrin who exchanges money for one's soul. In the course of survey, Bruce Byland was told about a site on the border between Jaltepec and Jaltepetongo where people walking in the area have heard the sounds of trucks moving about under the ground. The legend is that there is a spirit in the hill who owns a general store, where one can get all kinds of exotic goods not found in the Mixteca.

Likewise, Monaghan's (n.d.a.: 604-605) legend of the noso or yahui spirit who flies about like a ball of light includes references to its vast wealth kept hidden in the earth. This includes exotic goods such as trucks, radios, musical instruments, money, corn, beans, and squash. The word noso is a dialectical variant of ndoso or ndocio, the name of the god of the merchants to whom Don Juan was accused of sacrificing human beings in the Inquisition of Yanhuitlan (Jiménez-Moreno and Mateos Higuera 1940: 48-49).

To summarize, the yaha yahui was an office held by noblemen who performed rituals of human sacrifice and who were responsible for divining with the dead in order to prognosticate the future of the living. Access to the ancestors was through the magical ability of the yaha yahui to fly to the netherworld, a feat achieved through the use of hallucinogenic mushrooms and transformation. Traditional Mixtec religious ideology focuses on sacrifice as a metaphor for relationships of economic exchange. In modern communities, Mixtecs give $d z o c o$ or sacrifice to the saints on the occasion of festivals in return for their blessings and hopes for agricultural prosperity. In Precolumbian times the kings were the equivalent of saints. They bore titles of divinity and claimed sacred rights to control of the land by virtue of their direct ancestors, the $\hbar u h u$, who were born literally from specific geographical features (see Pohl and Byland 1990).

The kings collected tribute in the course of religious festivals honoring their ancestors (Fig. 21a). In so doing, the peasant class was "sacrificing" to the lord in return for the royal ancestor's gift of enabling the farmers to plant and to sustain themselves, that is to say to allow them to "eat the nuhu." The ultimate $d z o c o / s a c r i f i c e$ was the dedication of human life to the gods by the elite themselves. Clearly, such sacrifices could be made by dedicating one's rivals to the gods, as with 8 Deer's execution of his two half-nephews on Zouche-Nuttall 83-84. Seler (1904b: 278) reported a Oaxacan metaphor for the sacrifice of children as, "I pay my dept to the rain god." 


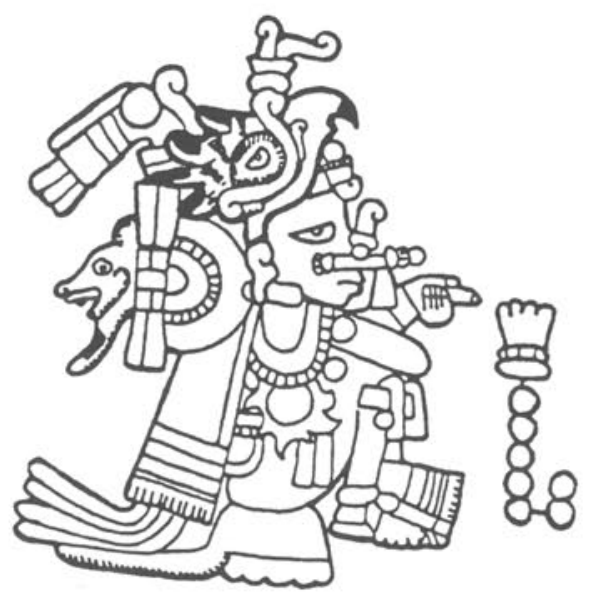

a

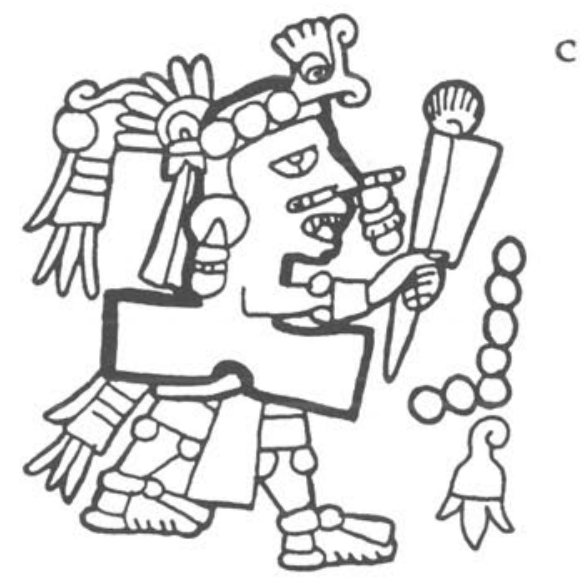

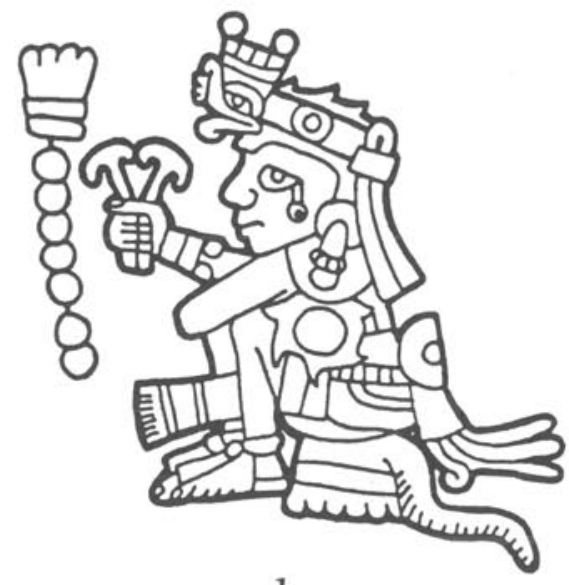

$\mathrm{b}$

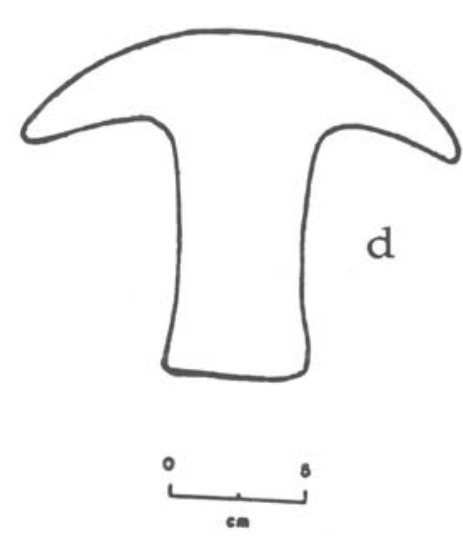

Fig. 21: (a) The deity 7 Flower (Tonacatecuhtli to the Aztec), was patron of the thirteenth or highest heaven according to Codex Rios/Vaticanus A. This was the royal ancestral paradise compared by the Spanish to the Classical Greek Elysian Fields. Here the deity-patron of ancestors is dressed as a yaha. (b) The patron of ancestors, 7 Flower, holds hallucinogenic mushrooms (Vindobonensis 24). (c) 7 Flower portrayed as a personified ingot or gold jewel (Zouche-Nuttall). (d) Oaxacan copper "money" shaped in the form of mushrooms. This piece was found with the remains of sacrificial victims in the Tenango Cave (See Winter 1989). 
The ancestors furthermore became associated with the wealth of the community that was supervised by the yaha yahui. For instance money is called dzinuhu in Mixtec (Alvarado 1962: 81). Ñuhu refers to the ancestral gods, whereas $d z i$ refers to either "sustenance" or a "kinsman" (Arana and Swadesh 1965: 83). Money could therefore be both the spirit of sustenance and the spirit of kinsmen. These meanings perhaps explain why Precolumbian copper money was shaped to resemble the silhouette of hallucinogenic mushrooms, the "flesh" of the gods (Motolinía 1951: 96) or ancestors eaten by the yaha yahui in divination (Fig. 21b). The source of these metallurgical forms is thought to be lower Central America, where the symbolism of gold and copper jewelry commonly includes mushroom themes (Schultes and Hofmann 1979: 64). Marcus Winter (1989: 88-89, 1990: 207) has reported on fascinating artifactual assemblages from Oaxacan caves that include sacrificial knife blades found together with copper "mushroom money" (see also Hosler, Lechtman, and Holm: 1990) (Figs. 21c and d).

\section{"DON DOMINGO," DON FRANCISCO," AND "DON JUAN" AS TITLES OF POLITICAL OFFICE}

The names of the three defendants in the Inquisition of Yanhuitlan also served as titles of political office and not simply as personal names adopted through Christian baptism. This is supported by the fact that many caciques and gobernadores serving as witnesses were also called Domingo, Francisco, and Juan (Spores 1967, Jiménez-Moreno and Mateos-Higuera 1940, Greenleaf 1969). Furthurmore, at least two of the Yanhuitlan defendants had changed their names shortly after being baptized. Don Francisco was originally named Alonso and Don Juan was baptized Cristobal. The new appellations were, therefore, most likely adopted in emulation of specific characteristics perceived in iconography or life stories of St. Dominic, St. Francis, and St. John.

Figure 22 shows the means by which early friars taught religious instruction to the native elite through the use of art and pictorial narratives of the lives of the saints (see Burgoa 1934 I: 43). The resemblance of these assemblies to the Preconquest gatherings of kings in which the codices were displayed is striking (See Códice de Yanhuitlan Lamina II). The Dominican Fray Benito Hernández (see Burgoa 1934 I) is even remembered through Dominican legend in Yodocono as having taught the Christian concept of the trinity with the use of three native idols. Louise Burkhart (1987) has shown that education through pictorial imagery was the principal means by which syncretic Christian theologies were developed in the New World. A comparison of Precolumbian narrative imagery and the church imagery of Europe should therefore be most instructive in understanding the origin and usage of symbolism on the part of the lords of Yanhuitlan.

First of all, we know that the Mixtec aristocracy was very interested in Spanish titles and their heraldic display. The shield of Tilantongo (Caso 1938: 59) is a fascinating syncretic 


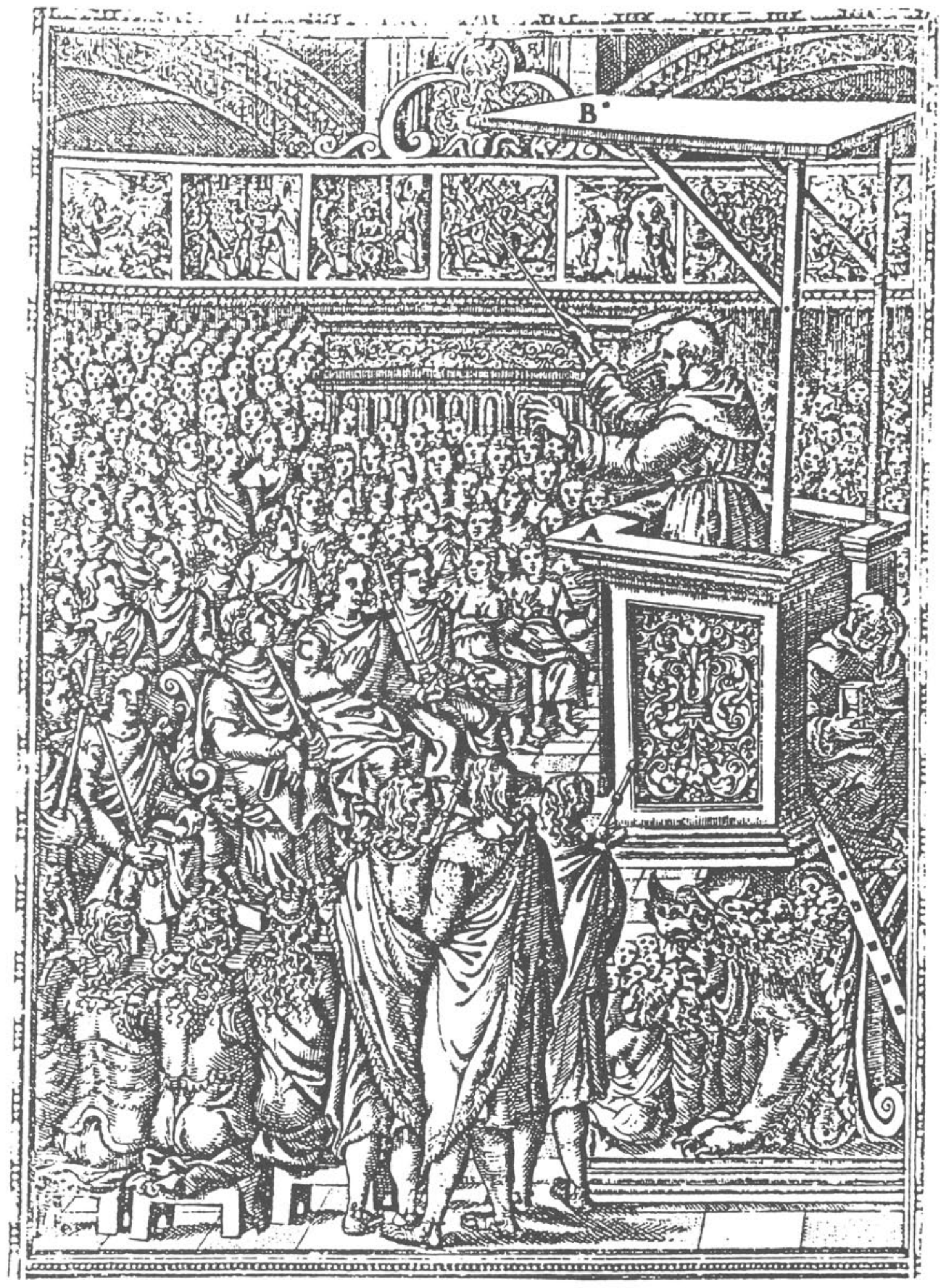

Figure 22: Spanish friar using contemporary paintings to illustrate Christian bible stories for native Mexican noblemen (from Valades' Rhetorica Christiana). 
image of "Spanish" heraldry in which codex style place signs have been carved to represent domains under the authority of Tilantongo's Colonial cacique. Likewise when the Tilantongo cacique was going to be baptized, he asked what name the Spanish king had. Upon receiving the answer, he declared himself to be "Don Felipe de Austria" (Burgoa 1934 I: 371). On the other hand, Domingo was not only the name of the gobernador-cacique of Yanhuitlan but also of the leader of the council of four priests practicing under Don Francisco (Spores 1967: 230-231). Much like Don Felipe de Austria; Don Domingo de Guzmán, took his name from the Castillian Santo Domingo de Guzmán (1170-1221 A.D.), founder of the Dominican order that had evangelized Yanhuitlan. St. Dominic and his followers were known for wearing black and white robes, as were Mixtec priests. In this regard, Seler reported an idolatry investigation that took place in San Francisco de Caxonos, Oaxaca, in which Colonial native priests dressed to emulate the Dominicans:

"An indian was reading from a sort of document covered with characters in red, certain prayers which the others repeated. In the crowd the Gobernador of the pueblo and two of the alcaldes were distinguished by special (priestly) dress, being clad in white cloth after the fashion of Dominican friars, and wore on their heads a kind of cowl or mitre... On a large table lay a couple of idols face downward and with papers on their back containing hieroglyphs, two bowls of blood, three tapers, a basket containing turkeys slaughtered and plucked... On the floor lay a large hind with its mouth in the air..." (Seler 1960 II88-89. English Trans. from the German under supervision of Charles P. Bowditch, Seler 1939: II 1:59).

St. Dominic often appears holding a white lilly, a symbol of chastity and the hearldic shield of the Dominican order is a cross bearing four "fleurs de lis" (See Parmenter 1964). The white flower was a diagnostic emblem of the robes of Mixtec priests as well. Perhaps more significant however are portrayals of events in St. Dominic's life with which Don Domingo might have been familiar. For example, the patriarch may be shown carrying the Christian church in his arm in a way similar to the transportation of the sacred temple by Mixtec priests (Fig. 23a). Likewise, when he died, St. Dominic was visited by angels who descended on ladders lowered by Christ and the Virgin. His body was placed on a throne and carried by the angels back up the ladders to paradise (Fig. 24) Both events as portrayed in art bear a striking resemblance in composition to Zouche-Nuttall page 19, in which Priest 12 Wind descends upon a rope ladder bearing a temple on his back. A Tilantongo legend still recounted today tells of a hero who was rewarded for an act of labor with a great church. However, he had to journey far away to collect it. Later, as he was carrying it back, he stopped at Yanhuitlan to rest. While he slept, the sun rose and burned him to death. The church of Santo Domingo then remained at Yanhuitlan.

Don Francisco's name was derived from St. Francis of Assisi. According to legend, St. Dominic had a dream in which he met a man whom he addressed as his "brother" (Fig. 23b). 

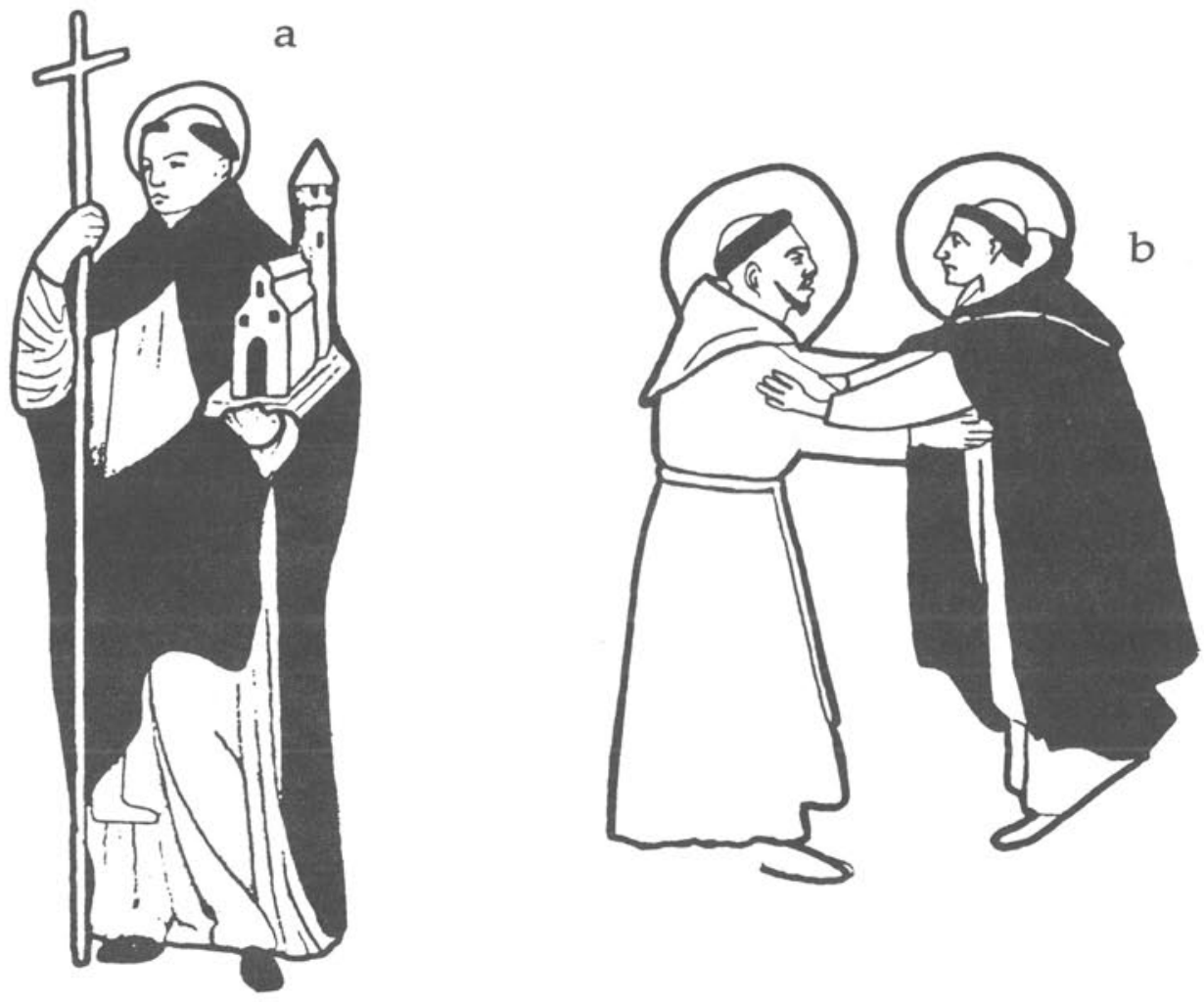

Figure 23: (a) Saint Dominic de Guzmán bearing a church (from Tecali). (b) Saint Dominic and Saint Francis embrace as "brothers" (after a painting by Fra Angelico).

He later recognized this man as St. Francis. The two saints, one Spanish and the other Italian, were subsequently linked with the revolution of the Christian church of their age. Together, the Franciscans and the Dominicans set out to evangelize the New World. Both orders had profound theological influence on each other, although at times they could also be rivals. In art, St. Francis and St. Dominic are often paired especially in the work of Fra Angelico. In some examples, St. Francis and St. Dominic embrace, and in others they kneel together below a scene of the Crucifixion or the crowning of the Virgin as the Queen of Heaven. According to Ross Parmenter (1964:163), the church of Santo Domingo at Yanhuitlan at one time contained paired images of St. Francis and St. Dominic, implying that both were venerated equally by the friars there. Finally, like St. Dominic, St. Francis is also represented with a white lilly. He originally wore gray robes and sometimes holds a human skull. Again, we see these symbols as 


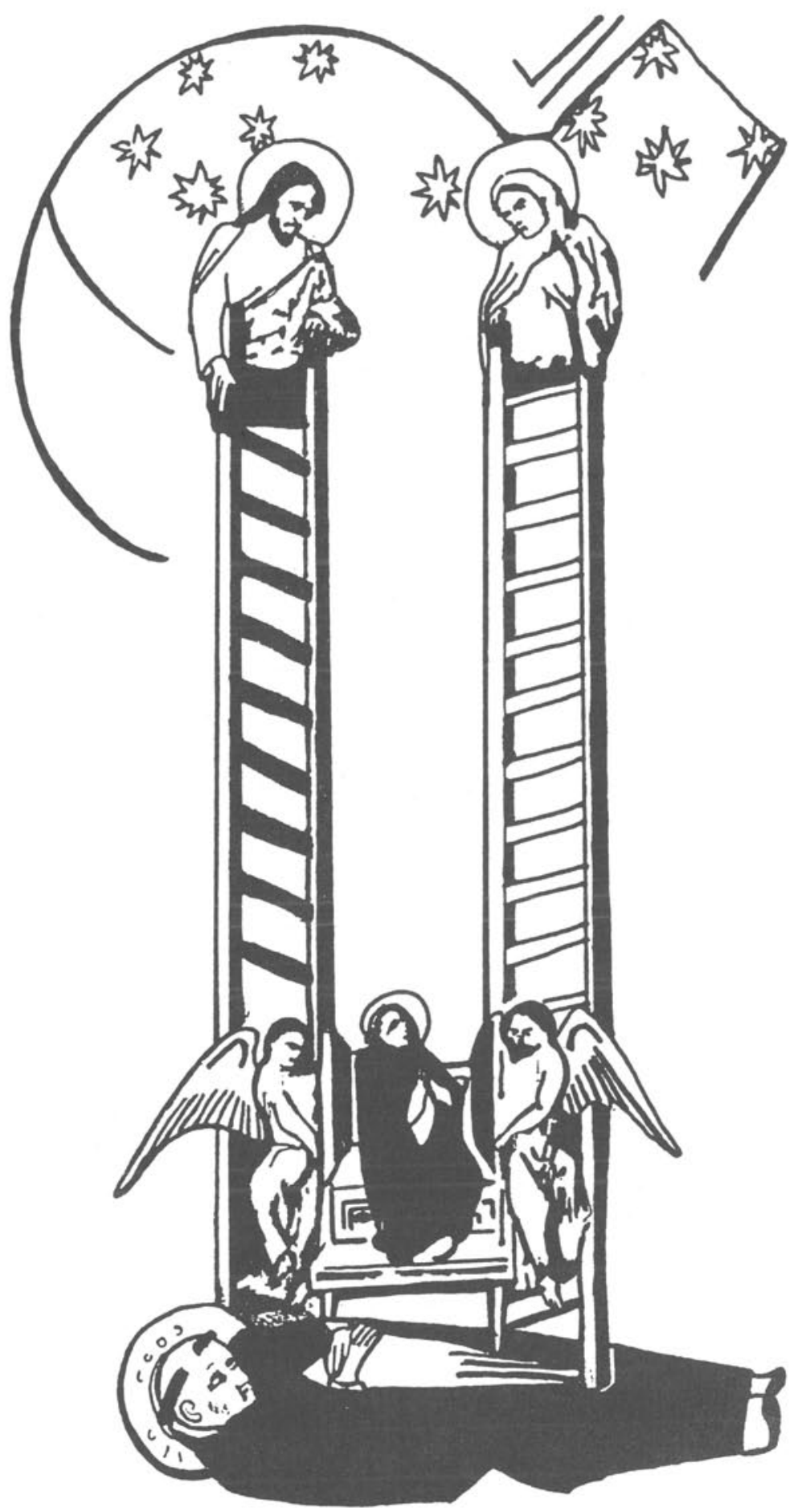

Figure 24: Upon his death Saint Dominic is taken to heaven on a ladder by angels (after a medieval Tuscan painting). 
attributes of Mixtec priests. The significance in the relationship between the two saints and their symbolic attributes obviously appealed to the two, highest-ranking native officials of Yanhuitlan.

The third gobernador of Yanhuitlan had changed his name to Don Juan in emulation of St. John. Just as St. Dominic and St. Francis were associated with symbols and events recognizable to the native understanding of the council of four priests, St. John is likewise associated with attributes that are comparable to the symbolism of the yaha yahui. St. John was a brother of Saint James or Santiago, the patron saint of Spain. He was present at the Crucifixion together with the Virgin Mary. From the cross, Jesus addressed the Virgin saying: "Woman behold thy son," and to St. John: "Behold thy mother." St. John then cared for the Virgin until her death.

Like the yaha yahui, St. John is associated with both the serpent and the eagle. The eagle is his principal attribute. In Colonial Oaxacan church art St. John is shown riding on the back of a great fire eagle (Fig. 25a). His association with the serpent derives from an attempt on his life by poison which was magically transformed into a snake-like dragon (Fig. 25b). Finally, John was banished to Patmos, where he wrote the book of Revelations, the prophesy of the future and the only biblical account of the Christian afterlife. In some religious paintings St. John is depicted in the course of turning sticks and stones into gold and jewels (Hall 1979: 175), an ability that could not have escaped the perception of native priests familiar with the role of the yaha yahui as economic administrator.

Besides the obvious symbolic comparisons between St. John and the attributes of the Yaha Yahui, legends still abound in the Mixteca of St. John's namesake, a legendary magician and healer named "Juan" or "Juanu" (Dyk 1959: 20-26). (18) Juan is the subject of stories involving caves. In Diuxi, for example, Juanu was out walking near a cave when he witnessed a miraculous vision of the Immaculate Conception. Today, the cave is one of the most sacred shrines in the Tilantongo Valley. Similarly, the ranch above the Jaltepec cave is said to have once been owned by Juan "the Chino." One of the names for the cave is the Cave of Sickness in which one divines with the devil for cures.

Figure 26 illustrates a painting by Fra Angelico. It depicts St. Dominic kneeling before the crucified Christ. On the left stands the Virgin of Sorrow, while on the right stands St. John the Evangelist. Fra Angelico was both a Dominican friar and a renowned Renaissance artist. We may view his work therefore as a primary representation of Dominican symbolism as it was understood by the friars of Yanhuitlan and communicated both orally and visually to the native lords, Don Domingo, Don Francisco, and Don Juan. The juxtaposition of these saints in Dominican religious ideology could have easily been seen as profoundly representative of Precolumbian Mixtec political ideology involving the sacrifice of the king, the head of the council of four priests, the earth goddess 9 Grass, and the Yaha Yahui. 

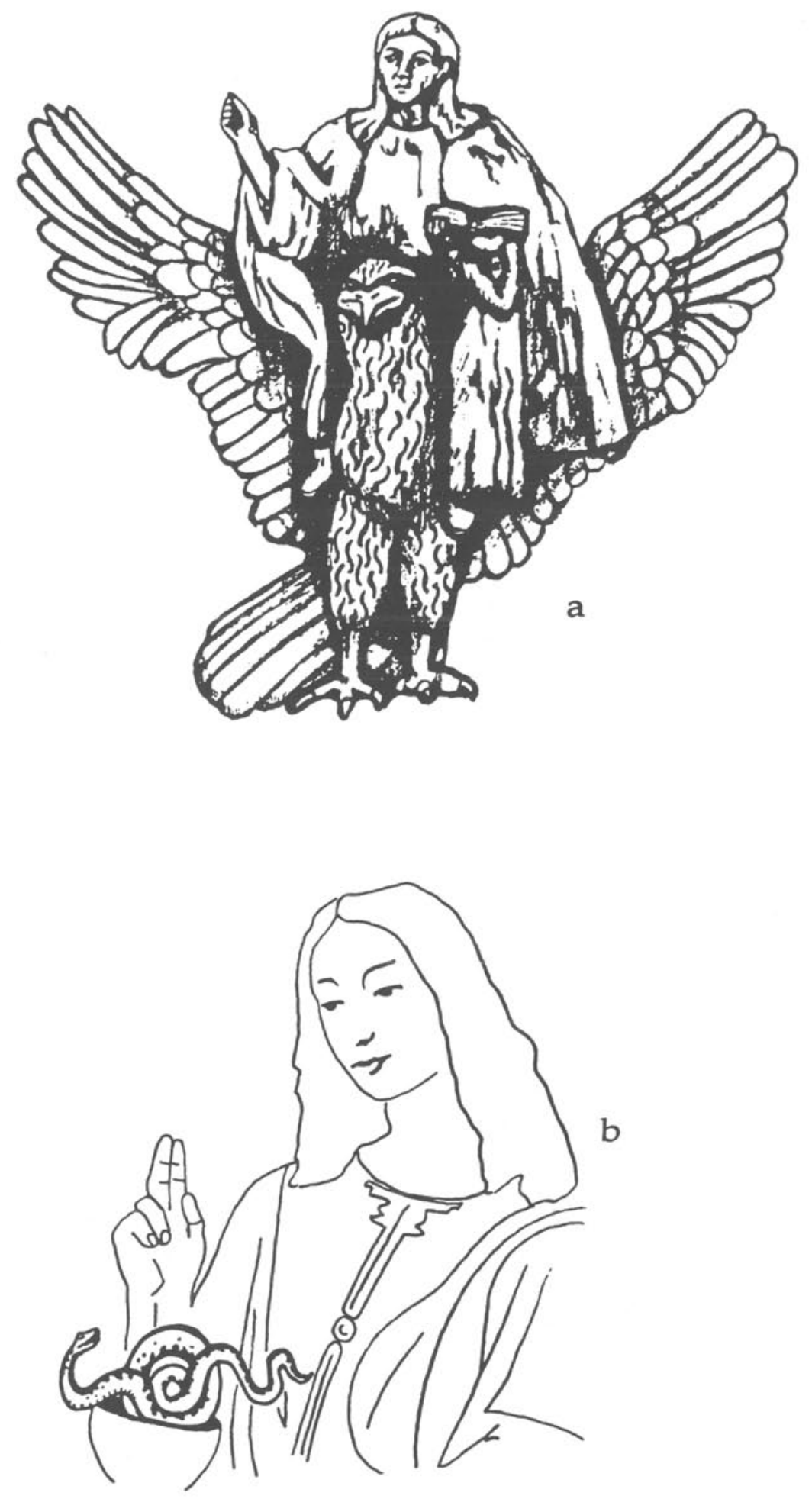

Figure 25: (a) St. John riding the back of a fiery eagle from a 16th to 17th century carving at the church of Santo Domingo, Oaxaca. (b) St. John and the serpent (after a painting by Piero di Cosimo). 


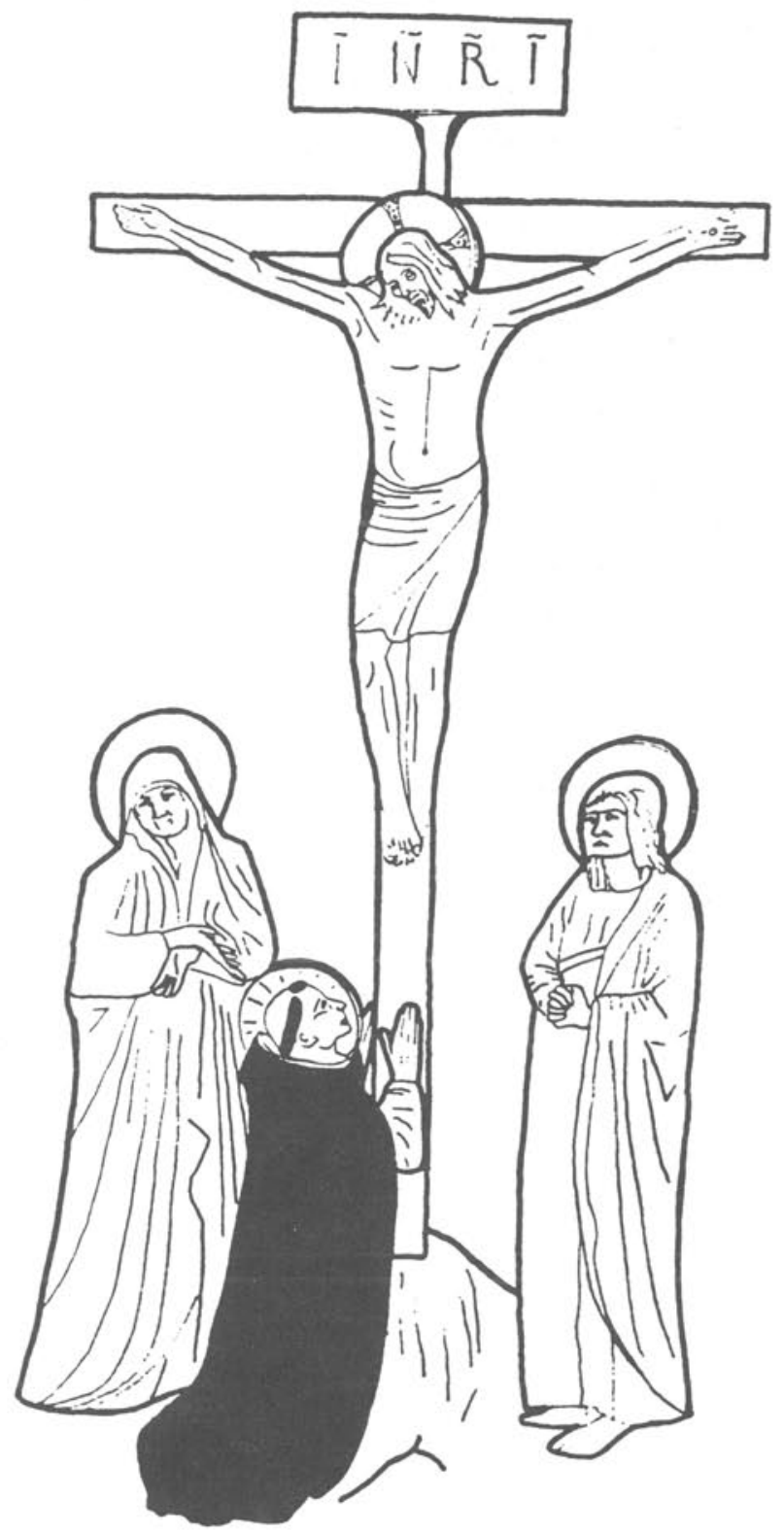

Figure 26: St. Dominic kneels before the crucified Christ. St. John stands to the right and the Virgin stands to the left (after a painting by Fra Angelico). 


\section{A TRI-PARTITE GOVERNMENTAL ADMINISTRATION}

In conclusion, an examination of the behavior of priests as related in both the Mixtec codices and Colonial written accounts permits us to deduce something of the internal structure and management of Postclassic Mixtec kingdoms. The priesthood fulfilled positions of secular authority, which were recognized by the Spaniards; hence they were not only addressed as "sacerdotes," but also as "regidores," "gobernadores," and "consejeros". Differentiation in ritual specialization further suggests that the Mixtec maintained a tri-partite governmental administration, formed by the "king" or yya, a council of four priests or dzutu sandidzo $\tilde{\text { nhu }}$, and the sacrificer-diviners or yaha yahui (Fig. 27).

Except for the Aztecs, studies of the governmental diversity of ancient Mesoamerican civilizations have been, for the most part, few and far between. The Triple Alliance is credited with incorporating a good deal of bureaucratic diversity in government, but this is traditionally seen as a late development, an adaptation to the problems of running an empire (See Carrasco 1971, Gibson 1971). The government of Tenochtitlan, for example, was administrated not only by the tlatoani or emperor, but by a council of four priests and the cihuacoatl, a high official who operated as chief councilor (See Berdan 1982, Rounds 1979, 1982). These offices, however, have been recognized in the Mixtec system as well.

Gordon Willey (1985: 16) once proposed that the Classic Maya lacked any great degree of governmental diversity, saying: "there is no evidence of any counter-balancing power within the chiefdom or state that could have held him (the Maya king) in check." However this more conservative view may be countered by the examination of non-paramount authorities on Classic period monuments (Schele and Miller 1986, Pohl and Pohl in press, Stephen Houston: personal communication, David Stuart: personal communication). During the Postclassic, Maya kingdoms were certainly characterized by different orders of religious practitioners: the $a h$ kin, and chacs (Marcus 1978). The degree to which they operated as political functionaries remains to be investigated.

Joyce Marcus $(1978,1983$ b) has examined certain characteristics of Zapotec religion and proposed a three-tiered hierarchy of priests. This was headed by the huipatoo or "great seer," followed by the bigana, or general practitioners, and the huetete/ueza-eche or sacrificers. The role of the huipatoo, however, is not described for Zapotec kingdoms in general, but rather huipatoo is the title reserved for the great oracles of Mitla. Michael Lind and Javier Urcid (1983) have proposed another form of tri-partite administration for the Zapotec. This included a king or coqui, the priests or bigana, and the golaba, a tribute collector.

Marcus', Lind's, and Urcid's proposals of a Zapotec tri-partite administration are nonetheless relevant to the appearance of stucco figures in Tomb 1 of Zaachila (Fig. 28). The east wall depicts the Coqui 5 Flower who appears in Zouche-Nuttall 33 as a king of Zaachila. Before him walks a skeletal figure which has been identified by Jansen (1982b) as a death god. Similarities in dress, however, also mark the figure as the Zapotec equivalent of one of the four 


\section{LORD}
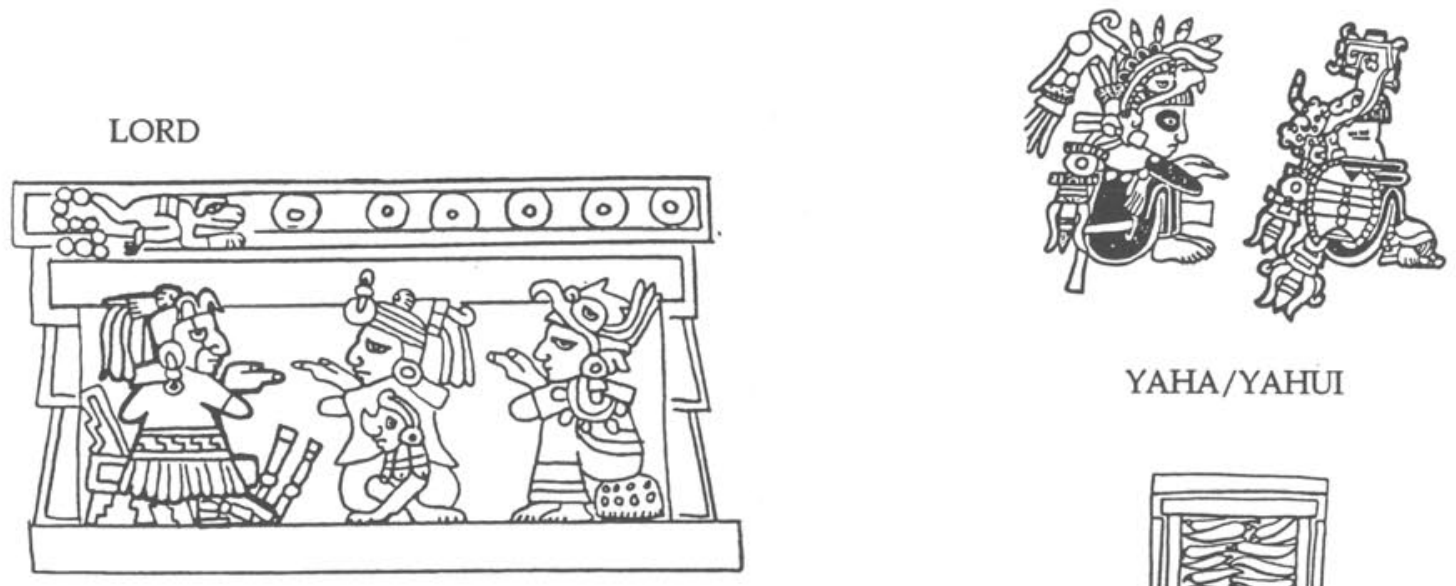

YAHA/YAHUI

PALACE

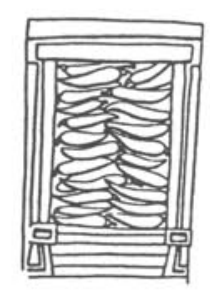

STORE

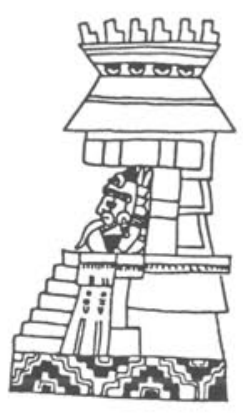

TEMPLE

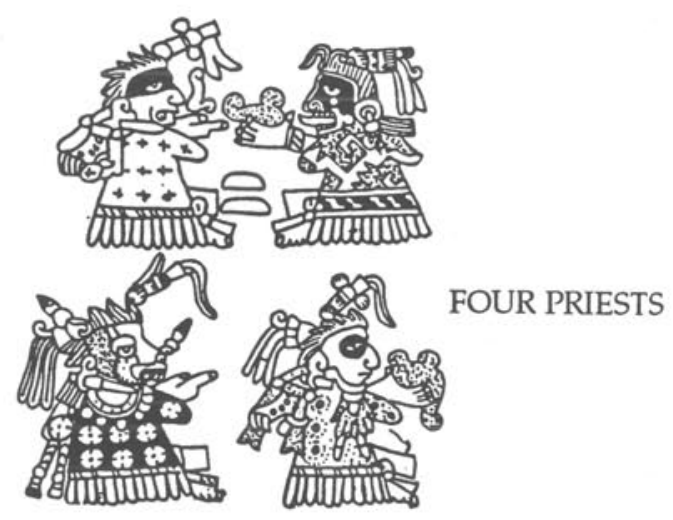

Fig. 27: Schematization of political diversity of a Mixtec kingdom in the codices points to a tri-partite administrative system. Each group is furthermore affiliated with specialized architectural forms. The kings appear before palaces, the four priests appear before the Temple of Heaven or some other holy shrine, and the yaha yahui are associated with markets or stores (see Charts 1 and 2). Each of these architectural representations should be verifiable as the components of actual Postclassic Mixtec capital sites (see Pohl and Byland in press). 
priests, or a bigana. On the rear wall of the tomb is a yaha yahui priest flying with sacrificial knives in his hands. Urcid (personal communication) proposes that his equivalent title in Zapotec was xicani (hechizero, nigromantico). It appears therefore that the tripartite division examined here for the Mixtec was also maintained by the Zapotec. Furthermore, the power with which these officials were invested was such that the Coqui did not even enter the afterlife without their assistance. Indeed, for the Mixtec we have seen that the four priests were responsible for the king's entombment, while the sacrificer priests were credited with the ability to communicate with the dead.

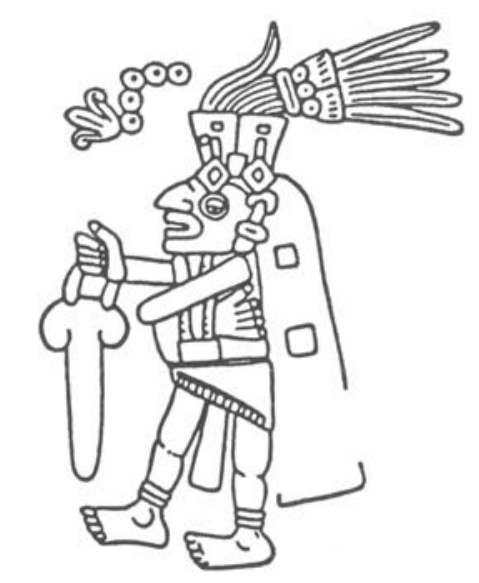

COQUI: LORD 5 FLOWER
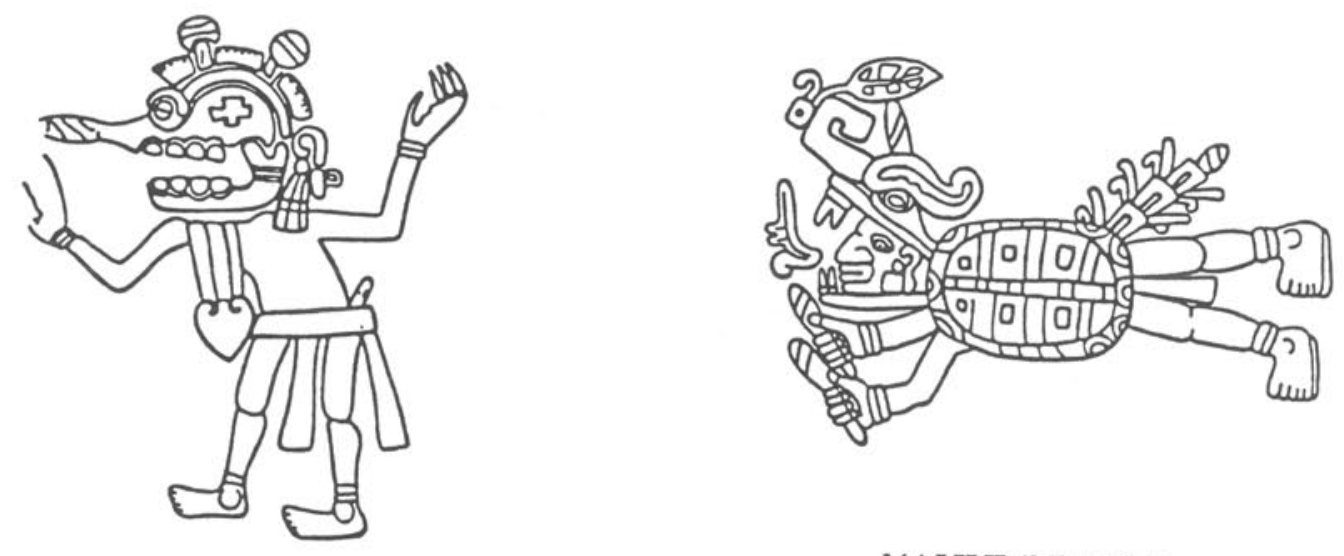

YAHUI/XICANI

BIGANA

Fig. 28: The tri-partite governmental scheme as symbolized in Zaachila Tomb 1. The Zapotec king 5 Flower (above) is guided to the afterlife by one of the four priests (bigana) and a yahui(xicani). 
Spores (1983: 236) recognized the relationship between the priestly Mixtec hierarchy and the management of elite estates, proposing that:

"..the rise of religious specialists to positions of secular power may have been fundamental to the origins of the Mixtec class system... (and later) the emergence of religious practitioners as a political elite undoubtedly was associated with a complex of reinforcing marital and political alliances and internal military conquest that promoted the exploitation of widespread resources and contributed to the overall integration of the social system."

However, Spores does not see priestly diversity as being necessarily representative of bureaucratic sophistication (Spores 1967, 1984).

The problem archaeologists will face in future studies is to define what they mean by governmental "complexity" (see Webster 1976). From an examination of the literature, arguments appear to rest on the number of bureaucratic posts and the degree of institutionalization. For instance, were religious practitioners full time residents of the royal courts, or were they members of the junior nobility absorbed in the management of their own estates until called upon to fulfill certain governmental obligations as vassals to the king? Herrera (1945: 170) said that the Mixtec priesthood was fully residential at the royal capital. They lived in their own quarters, rarely venturing forth except to direct the festivals. The king even maintained special lands to grow crops and provided the priests with servants. If the priesthood was residential, we may also be seeing a fully residential and diversified elite administration in the codices (Pohl and Byland n.d.b.).

On a regional scale, the Mixtec were organized into multiple factionalized kingdoms each directed by an autonomous paramount. Nevertheless, the kingdoms appear to have ranked themselves, acknowledging Tilantongo as the seat of the highest ranked lineage. This implies that there were mutually recognized social constructions which united the Mixtec. Consequently, we may not be seeing simply a "balkanization" or divergent evolution in Oaxaca (Flannary and Marcus 1983) during the Postclassic with a concomitant rejection of national unity, but rather a diversification of political strategies with certain kingdoms engaging in forms of bureaucratic specialization. The differences in the management and sophistication of government between the Aztec and the Mixtec is that the Aztec had a centralized government with most, if not all, political functions being carried out within a capital precinct. We will now examine the Mixtec evidence for national political strategies without centralized government. 


\section{9 GRASS AND THE ANCESTOR CULT}

The unfortunate results of dynastic disputes are clearly recognizable in the Mixtec pictorials by the portrayals of death by sacrifice. For instance, during the generation prior to that of Lord 8 Deer and Lady 6 Monkey, many sacrifices are listed, but the perpetrators remain anonymous. 8 Deer lost three half-brothers named 9 Movement, 3 Water (Bodley 7IV), and 12 Movement (Zouche-Nuttall 81), and 6 Monkey lost three brothers (Selden 5IV-6I). Since 8 Deer's half-brothers were from his father's first marriage, they stood in a more favorable position to claim royal titles. Likewise, Lady 6 Monkey's brothers were in favorable positions due to age. Because such unexpected and violent deaths cause breaks in the normal and accepted rules of succession, the interregnum probably became a period of political upheaval as competitive elites sought to realign themselves and to better their status.

The decentralized political system of multiple ruling families in the Mixteca added further complications. Marriages between the royal estates were strategically planned through several generations, even though the system of inheritance could be variable (Herrera 1945: 168). 8 Deer is a prime example of an ambitious lord who, following the failure of the first dynasty at Tilantongo, sought to rule there himself, and so to begin a second dynasty. He accomplished this not only by warfare and marital alliances but through meetings with important religious figures, among whom Lady 9 Grass was perhaps the most influential.

Lady 9 Grass was not only a highly charged sacred power in the Mixteca, but also a personage who supervised the settlement of disputes and the mediation of royal authority among competing families. Jack Goody best summarizes the problems of this sort of interregnum in which 9 Grass was so important.

"Where succession occurs after death, the gap between death and succession is of critical importance to the state. It is the time when changes in organization, such as the establishment of a new dynasty, are most likely to occur. Whatever the continuity gained by the co-rulership of two kings in joint harness (partial transmission) by the immediate proclamation of a new heir (le roi est mort...), by concealing the death of the king, or by a highly determinate system of succession, the changeover from one ruler to the next is always a period of danger to the state. For not only is the government vulnerable to internal pressures for the redistribution of power, but the nation is also more open to attack from without". (Goody 1966:10).

All elite organizations therefore maintain balancing systems in order to avoid, or at least minimize, power conflicts. As we have seen, these balancing systems often fall to the sacred or religious authority because individuals operating within this realm in a sense supersede the power of the rulers. This is because they are not only powerful individuals in their own right in deciding earthly affairs of state, but are also believed to be in direct contact 
with the supernatural. For the Mixtec, affairs of the supernatural are highly political for they focus on the deified ancestors of the main dynasties. The interaction between Lady 9 Grass and the various rulers during 8 Deer's time suggests that she is the focus of just such a balancing system operating outside the limits of local autonomy at a national level. Furthermore, she appears to have served as one of several oracles which were described by Burgoa (1934 I and II) as having superior authority in some matters even to the kings. The Spanish likened these religious officials to Late Renaissance archbishops or even popes.

\section{CASE STUDIES}

\section{GRASS AND 6 MONKEY}

Lady 6 Monkey, the queen of Jaltepec, only appears once in the Zouche-Nuttall 44B. The year is 6 Reed, and the day is 6 Serpent. She is shown at a meeting where 9 Grass, seated in a skull temple, presides over the body of 3 Lizard (Fig. 29). 8 Deer is also present. Selden 6 IIIIV shows 6 Monkey together with her husband 11 Wind, the lord of Red and White Bundle. 9 Grass, again seated in a skull temple, appears to be officiating over their proposed marriage (see Spinden 1935). There are numerous precious objects shown which may be gifts from 9 Grass to the royal couple. Though the year is listed as 5 Reed, it should actually be 6 Reed, and one may presume that, since the day 6 Serpent is also noted, this meeting and that on ZoucheNuttall 44 are cognate portrayals. (19).

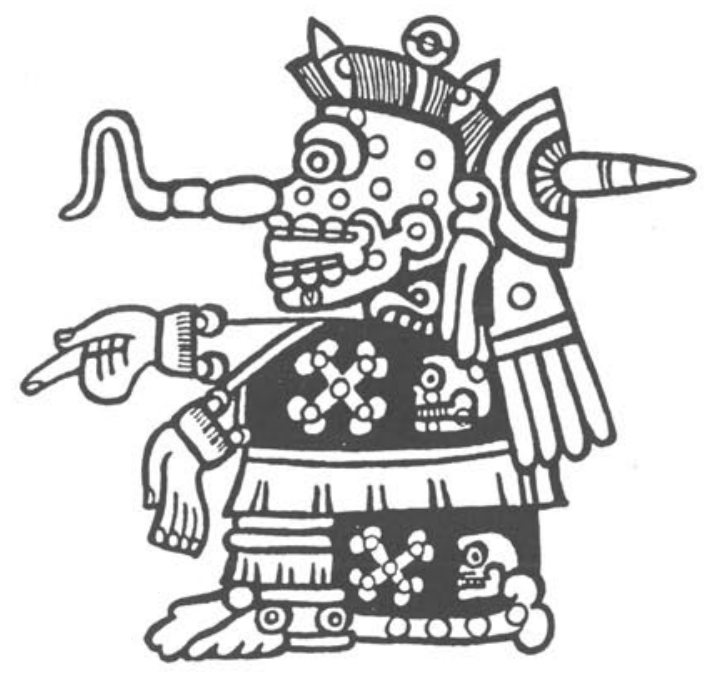

Figure 29: The oracle Lady 9 Grass (Zouche-Nuttall 44). 
On Selden 7 IV, 6 Monkey meets with 9 Grass again. This time it is in relation to a dispute between 6 Monkey and the lords of Hill of the Moon and Hill of the Insect, who apparently spoke "flinted words," a metaphor for an insult (Spinden 1935). Following this meeting, which is also attended by two warriors, 6 Monkey sacrifices the offending lords at Jaltepec and Red-and-White Bundle. Two important aspects of 9 Grass's position, then, seem to be her superiority in relation to 6 Monkey and the need for 6 Monkey to consult her both before marriage and before waging war.

9 GRASS, 8 DEER, AND 4 WIND

The Colombino lists two meetings between Lady 9 Grass and Lord 8 Deer. The first, on Colombino 4I, appears on Zouche-Nuttall 44 as well. 6 Monkey is again present. During this first meeting, which is cognate to that in Selden 6IV, 9 Grass presents numerous objects to 8 Deer. The most important are an arrow decorated with an owl head, a shield embossed with a skull, a golden fish, a conch shell, and a blue cogwheel-shaped object representing a turquoise-inlaid mirror (See Taube 1983).

Following this meeting, 8 Deer, escorted by priests who bear the gifts from 9 Grass in addition to the sacred bundle, first travels to places that probably have sacred directional significance; and then he assumes the throne of Tututepec (Colombino 5 II-I) (See Smith 1973a). 8 Deer's next meeting with 9 Grass comes fourteen years later (Colombino 12 III), just prior to his journey to "Cattail Place," where he receives the nose ornament from the foreign benefactor 4 Jaguar. In Codex Colombino it is evident that 8 Deer must consult with 9 Grass prior to his accession to the rulership of Tututepec and prior to his receiving the nose ornament, a device which I will argue symbolizes a lord's claim to be a lineage head (see Chapter V).

Like 8 Deer, 4 Wind meets twice with Lady 9 Grass. Bodley 33 V shows 4 Wind meeting with 9 Grass directly after 8 Deer's conquest and sacrifice of the rulers of Red-and-White Bundle, 6 Monkey and 11 Wind (4 Wind's parents) (see Troike n.d.b.: 336-337). He also meets with other oracles or deity impersonators, including the god 1 Death (Bodley 33IV). (20) Following these meetings, he has a dispute with Lord 4 Jaguar but eventually is awarded the yacaxihuitl nose ornament and establishes himself at Place of Flints. On Bodley 32 V, 4 Wind meets with 9 Grass and is presented with a red xicolli and two jewels. After this scene, he again meets with sacred authorities before finally marrying 10 Flower, the daughter of 8 Deer and Lady 13 Serpent.

This brief summary of 9 Grass's interaction with three rulers, Lord 8 Deer, Lady 6 Monkey, and Lord 4 Wind, tells us a great deal about her importance to Mixtec elites whose political status is in doubt, or at least unclear, due either to the multiple marriages of parents or to warfare leading to displacement (see Chart 3). She is a person who is consulted on affairs of marriage and accession but is not necessarily able to promote a lord as ruler. Rather, 
She acts as an arbitrator between rulers who find themselves in dispute. She assists in establishing Lord 8 Deer, Lady 6 Monkey, and Lord 4 Wind as the rulers of powerful Mixtec kingdoms.

She supervises an important burial shrine at Skull Temple/Skull Place as the oracle of Chalcatongo.
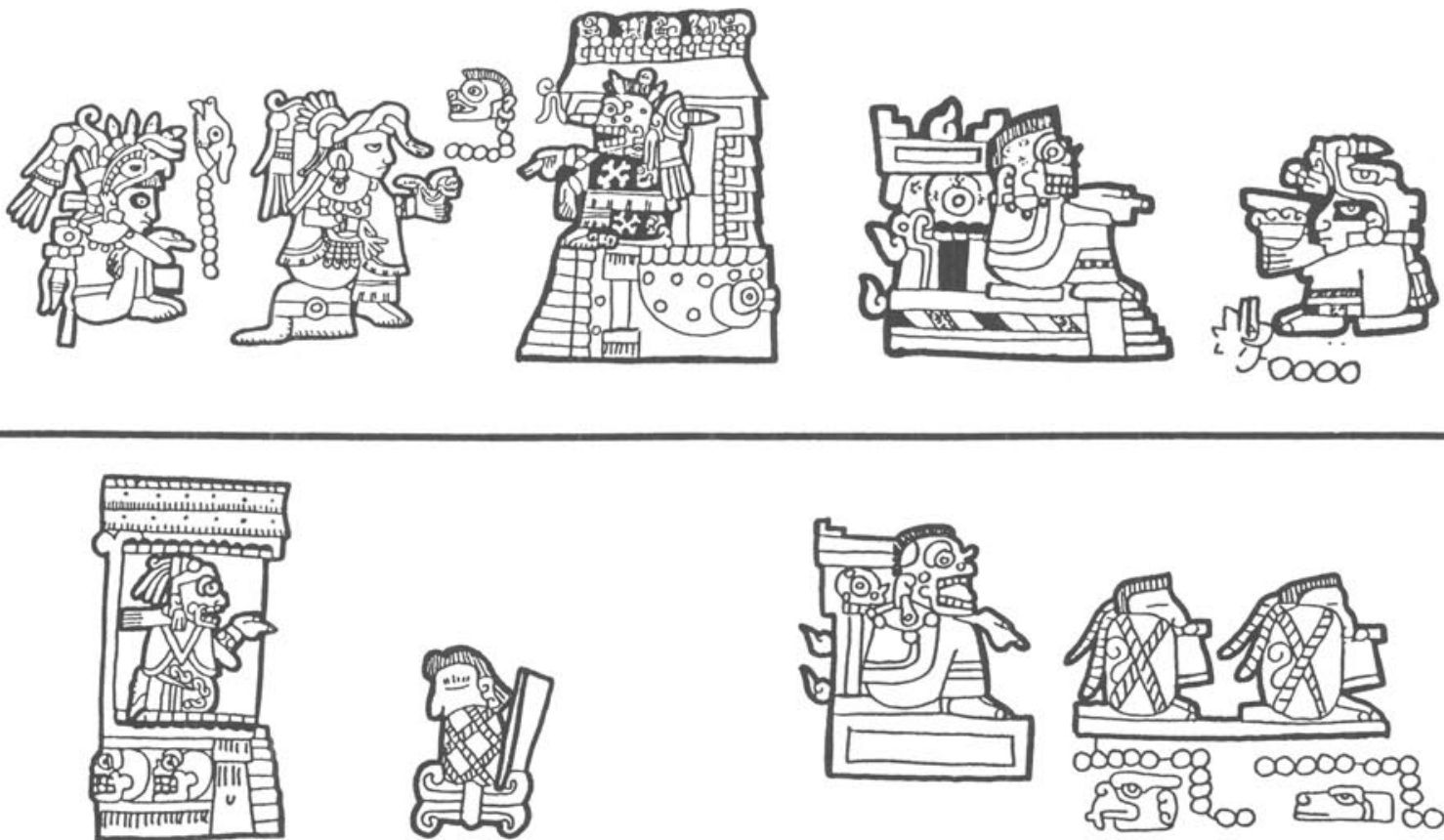

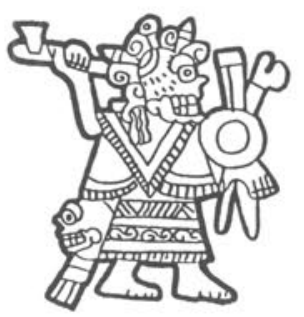

CHART 3

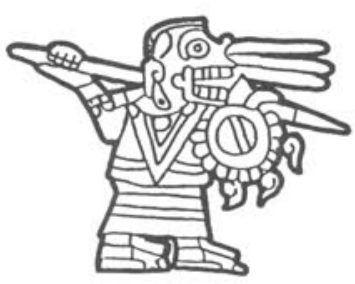

BEHAVIORAL CHARACTERISTICS

OF THE DEITY-IMPERSONATOR 9 GRASS 
she is an advisor who is consulted by important personages before they assume rulership. She is consulted by both 6 Monkey and 4 Wind before they marry. 6 Monkey's marriage represents the joining of Jaltepec to Red-and-White Bundle, while 4 Wind's represents an alliance between Place of Flints and Tilantongo. 8 Deer consults 9 Grass before ruling at Tututepec and later before receiving the nose ornament, a status-increasing device transforming him into a lineage head.

To summarize her importance in Mixtec historical reckoning, we can say that Lady 9 Grass is crucial during periods of transition in the rulership positions of important kingdoms in the Mixteca Alta. She is prominent in the Vindobonensis Obverse, where she appears six times. Vindobonensis 33, 28, 25, and 24 all depict her as a participant in important rituals involving bloodletting, pulque, and mushrooms (see Furst 1978a: 172-206 for an analysis of the religious significance of these rites). Vindobonensis pages 14-15 are significant, as they show 9 Grass's institution at "Skull Temple" and list attributes associated with her and the cult over which she presides.

At the top of page 15, four priests make offerings to 9 Grass. The first is holding a quail. In Chapter II, I proposed that this ceremony is performed by priests for prominent Mixtec rulers after they mythically emerge from the earth or before they accede to a royal position. At the bottom of page 15, 9 Grass is shown seated in the skull temple and gesturing, as though making a demand. This is also how she is depicted when meeting with 8 Deer, 6 Monkey, and 4 Wind. Among the ritual objects associated with her and "Skull Temple" are a heart/blood glyph, a house with a dead man seated inside, jewels like those she presents to her royal visitors, a man who is descending and pouring blood onto a cornfield in which another dead man is seated, and, finally, a mummy bundle.

These objects and persons all suggest that 9 Grass is involved with rituals linked to blood and corn, sacrifice, and the burial of the dead. Her connection with sacrifice points to a pronounced martial aspect that she displays during the "War of Heaven" and elsewhere. Zouche-Nuttall 20 shows her heavily armed and expressing hostility to a priest named 9 Wind. Likewise, Bodley 4 III shows her standing on a war band and thrusting a lance. This bellicose pose is in some way connected with the mummy bundles of the couple 12 Lizard and 12 Vulture, the rulers of Hill of the Sun and "Mountain that Opens Up-Bee" or "Mountain that Opens-Hill of the Wasp", respectively. Bodley 35-34 I replicates this scene but relates it to a group of important persons who are shown diving into the earth, in much the same way as 6 Monkey on Selden 6 III. The "diving into the earth" pose could be representative of either a real or magical entry into the earth. Stories of tunnels which magically connect sacred shrines abound in the Mixteca today. For example, a tunnel is said to exist linking the ruins of Tilantongo to Achiutla. Monaghan (n.d.a.: 161) recorded stories of tunnels that recount the emergence of the first Nuyootecos. Some say a tunnel links Nuyoo with Chalcatongo, others say its origins are in Zaachila. Note that in all of these instances the places being referred to were powerful Postclassic capital sites. 
9 Grass is often associated with a distinctive temple. Selden $6 \mathrm{I}$ is a typical example. The base is shown as a frieze of skulls while the temple itself is literally a skull with the cranium serving as the roof and the jaw serving as the door jamb. Skulls are associated with the underworld deities throughout Mesoamerica, and it is noteworthy that if one were literally to enter this temple one would be passing through a gaping skeletal mouth.

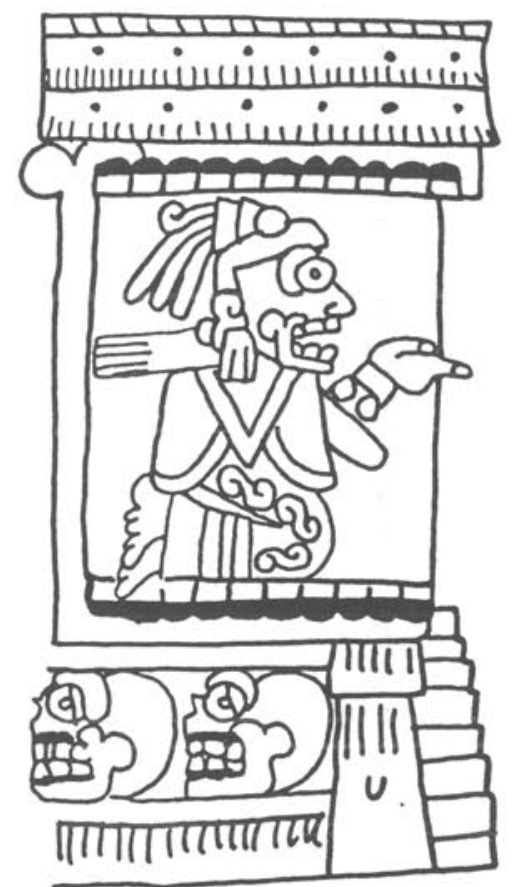

Figure 30: The Temple of Lady 9 Grass (Vindobonensis 15).

Perhaps the most interesting aspect of "Skull Temple" as portrayed on Vindobonensis 15 is the "jawbone" step and lintel combination (Fig. 30). Caso's Mixtec language adjunct to the Alvarado dictionary (Alvarado 1962: 138) lists the Mixtec words for quijada or "jawbone" as yeque yuhu. Yeque means "bone" and yuhu means "mouth." The Arana-Swadesh (1965: 137) dictionary, however, lists an additional meaning for yuhu as "sepulcre," so that yeque yuhu could mean "bone-tomb." The portrayal of a jawbone for 9 Grass's temple therefore simultaneously identifies a tomb as well as some sort of entryway to the underworld, perhaps a cave.

The skull temple is in fact associated with an important place sign called "Skull Place." For example, on Selden 7IV, the skull temple is associated with a warrior seated upon 
"Skull Place." Bodley 14IV shows that following his death by sacrifice or assassination, 8 Deer was mummified and entombed in some type of structure at "Skull Place," while Selden 5IV-6I shows that 6 Monkey's three brothers, who were also sacrificed, were buried at "Skull Temple."

"Skull Place" can now be identified with some certainty as Chalcatongo, an important site in the Southern Mixteca Alta (Jansen 1980:29, 1982). Reyes (1976: 89) listed the original name of Chalcatongo as Nuundaya. Ñuu means "town" or "place," while ndaya means "hell" or the "underworld." Jansen proposes, then, that the "skull" qualifier stands for ndaya. Furthermore, Burgoa described a great burial cave that was located in a mountain at Chalcatongo and which was destroyed by Fray Benito Hernández (Burgoa 1934 I: 337-340). The mountain was called Cumbre de Cervatillos or "Summit of the Musk Deer." Indeed, Selden 7IV shows two warriors associated with two place signs. The first is seated at "Skull Place" and the second is seated upon a hill substantive, qualified by a small deer. Although neither of these places have been specifically identified, modern legends describe the dead as residing at Yucu Casa, a mountain that had once been part of the kingdom of Chalcatongo (Monaghan n.d.a.).

Burgoa states that the cave was venerated by all of the lords of the Mixteca and that it was well known that the ancestors of Don Felipe de Austria, the Colonial cacique of Tilantongo, were buried there (Burgoa 1934: I:372). The Lady 9 Grass therefore appears to have been the oracular priestess of the great burial cave of Chalcatongo described by Burgoa. The evidence also suggests that 9 Grass operated in terms similar to that of the huipatoo, or "great Seer," of the Zapotec.

The Zapotec living in the Valley of Oaxaca during the Postclassic period were also divided into dispersed communities, each ruled by a paramount elite. The highest ranked lineage was the royal house of Zaachila. These Zapotec kingdoms derived a sense of unity from their allegiance to a high priest called the huipatoo, who was installed at Mitla. The huipatoo was said to have superior power over all the kings of the Valley of Oaxaca (Burgoa 1934 II:120-126, 350-351). He also had an oracular aspect and made prophesies for the kings as well as supervised the settlement of disputes.

Finally and most importantly, he presided over a cult focusing on the deceased lords of Zaachila, whose remains had been brought to Mitla for burial in caves. Mitla was called Yooba which can be translated as "Burial House" in Zapotec (Burgoa 1934 II:64, Pickett et al. 1959). The huipatoo also supervised the important rituals and sacrifices that were held at Mitla, where the principal idol was worshipped as the "Corazon del Reino" in much the same way as the Mixtec sacred bundle was worshipped at Achiutla (Burgoa 1934 II:351). Burgoa goes on, not only to compare the burial rituals between the Zapotec and Mixtec, but to state:

“...y administración de este pueblo no toca a esta provincia,porque es beneficio secular, por ser el sepulcro de los reyes de esta Zapoteca... Y en la Mixteca de la cueva de Chalcatongo, 
para sepulcro de sus sefiores, y aqui para los de la Zapoteca..." (Burgoa 1934 II:121).

The similarities between the Zapotec huipatoo and the Mixtec 9 Grass are notable. First, both are highly charged religious figures who have been attributed powers that were superior to those of the royal aristocracy. Second, they both preside over a burial cave that was the focus of a cult rooted in the worship of the dead ancestors of the principal royal lines of Zaachila and Tilantongo. Third, they are persons who, while they supervise the activities of the living, also preside over the cult of the dead. This system of combining ritual and political management would be beneficial to all concerned.

The maintenance of a funerary cult that centers on the grouping of the remains of the royal dead in a central place is ingenious. In societies like the Mixtec and Zapotec, rank was traced through one's familial relationship with one of the royal lineages. By controlling access to the divine dead and managing their cult, a sacred authority like 9 Grass was actually manipulating the affairs of the living descendants, for they were forced to use her as a mediator. The funerary cult thereby provided a focus of national identity and ensured political stability among various members of the competitive, factionalized royal kin groups.

Burgoa (1934 I:338, II:151) uses two important terms in relation to the Mixtec and the Zapotec views of the burial caves and the afterworld. Both cultures saw the cave as a gateway or point of transit between the world of the living and the world of the dead. Some degree of supernatural life must have been accorded the dead, for Burgoa compares their world to that of Elysium in the Greek sense. Elysium was a beautiful meadow on the banks of a river. Only kings, queens, and heroes, the favored of the king of the gods, Zeus, are carried there, where they live a life of perfect happiness without having seen death.

"...fue este de Chalcatongo, donde como avariento, hasta de los cadáveres pútridos, y corruptos, quiso tener dominio, y modo de veneración, persuadieno a sus reyes y senores, que depués de aquesta vida, le ofreciesen los suyos, como en homenase de la otra, en aquella pira, o sepulcro, general depósito imaginado, para los Campos Elíseos, que inventó la gentilidad, haciéndoles creer, que aquella era la puerta, o tránsito para amenas florestas, que les tenía prevenidos a sus almas y aunque ruín, falso, y mientiroso, no les negó la immortalidad, pero añadió la resurrección de los cuerpos..."(Burgoa 1934 I:338).

From Burgoa's description of the Chalcatongo cave, it must have been impressive. It was filled with idols, objects in gold, wood, precious stones, and codices. Unfortunately, the cave has never been relocated since its original discovery and destruction by Fray Benito Hernandez. However, Mixtec burial caves similar to that at Chalcatongo have been reported by Christopher Moser (1983) for Ejutla and by Bruce Byland and myself (in press) in the Jaltepec/Tilantongo vicinity. The Ejutla cave was composed of a main gallery which is four to six meters from floor to ceiling and ten to twelve meters in diameter. Inside the gallery the 
Mixtec had constructed stone and adobe platforms and enclosed rectangular structures. Each of the structures had been sealed, but looters had broken down most of the walls to get at the contents.

Archaeologists from a University of Michigan team (Moser 1983) examined much of the looter's back dirt and discovered mummified human remains, fragments of burial masks inlaid with turquoise, earspools, weapons, necklaces, sandals, clothing, paper, and small baskets possibly used for holding birds (quail?) or other small animals. It appears that the rectangular enclosures were in fact containers for the mummies of a group of elite persons comparable to the structures shown in Bodley $14 \mathrm{~V}$, where 8 Deer's mummy bundle is encased in a small masonry structure, together with jewels, a headdress, and a sacred staff. The discovery of a child's mummified foot also corroborates Herrera's statements about corpses being treated with aromatic oils for preservation (see Dahlgren 1954:338).

Caves are still considered sacred throughout the Mixteca today. Jansen (1980:23) has recorded myths involving a cave called "yahui coo maa" or "Cueva Profunda de la Serpiente" in the Apoala Valley. The entrance is located above a spring which emerges from an underground river. Inside the cave there is a stalagmite that is called "The Archbishop," still an object of veneration. The most striking detail, however, is that The Archbishop actually "talks," which is to say that the passage of water through the underground chamber reverberates and duplicates the sound of a very low human voice. This is significant, since Burgoa (1934 II:350) suggested that the huipatoo was to be compared with an archbishop or pope.

Another legend is told today in Tejupan and recorded by Bruce Byland (personal communication). It is believed that there is an underground temple in the mountain above the town in which the bodies of the old lords are buried. A green-feathered snake sits at the entrance and guards the bodies against intruders. Monte Negro and other mountains throughout the Tilantongo Valley are also said to have numerous caves with long subterranean passages. The Cave of the Angel or Cave of Sickness lying a few kilometers southwest of Jaltepec also has remnants of Pre-Columbian burial structures like those described by Moser. It too is protected by a fabulous serpent. Clearly the Mixtec were, and still are, cave worshippers. The dead were buried in caves, regarded as transits to a kind of royal paradise. Ancestors were therefore considered to be "active" in the underworld and to play a role in the affairs of the living.

\section{LADY 9 GRASS AND FEMALE SKELETAL IMAGERY}

A sophisticated political system is supported by a set of sophisticated political symbols. Abner Cohen proposed that these symbols are:

"objects, acts, concepts, or linguistic formations that stand ambiguously for a multiplicity of disparate meanings, evoke sentiments and emotions, and impel men to action" (Cohen 1976:I). 
Obviously, symbols manifested in sacred bundles, regalia, and costume were of primary concern to the Mixtec. 9 Grass's regalia can be seen as a combination of political symbols. Her costume imagery and the rituals with which she is associated tell a great deal about symbolism and politics in ancient Oaxaca. The most marked aspect of 9 Grass's costume attributes are the combination of skirt and blouse-like quechquemitl, representative of the lifegiving female deities in Postclassic Mexican iconography, together with the skeletal jaw/mask or headdress representative of death deities. (21). This fusion of seemingly opposite principals reflects the Precolumbian view of life and death as cyclical and further emphasizes 9 Grass's role as a deity/deity impersonator or oracle who is concerned with transitional states of existence in both the political and religious realms. This symbolic transition between the living and the dead appears in codices of the Borgia Group. Fejervary-Mayer 28 shows a female-skeletal deity opening her mouth, from which a man emerges, while Borgia 5 shows a similar scene but with the man being swallowed (Fig. 31).
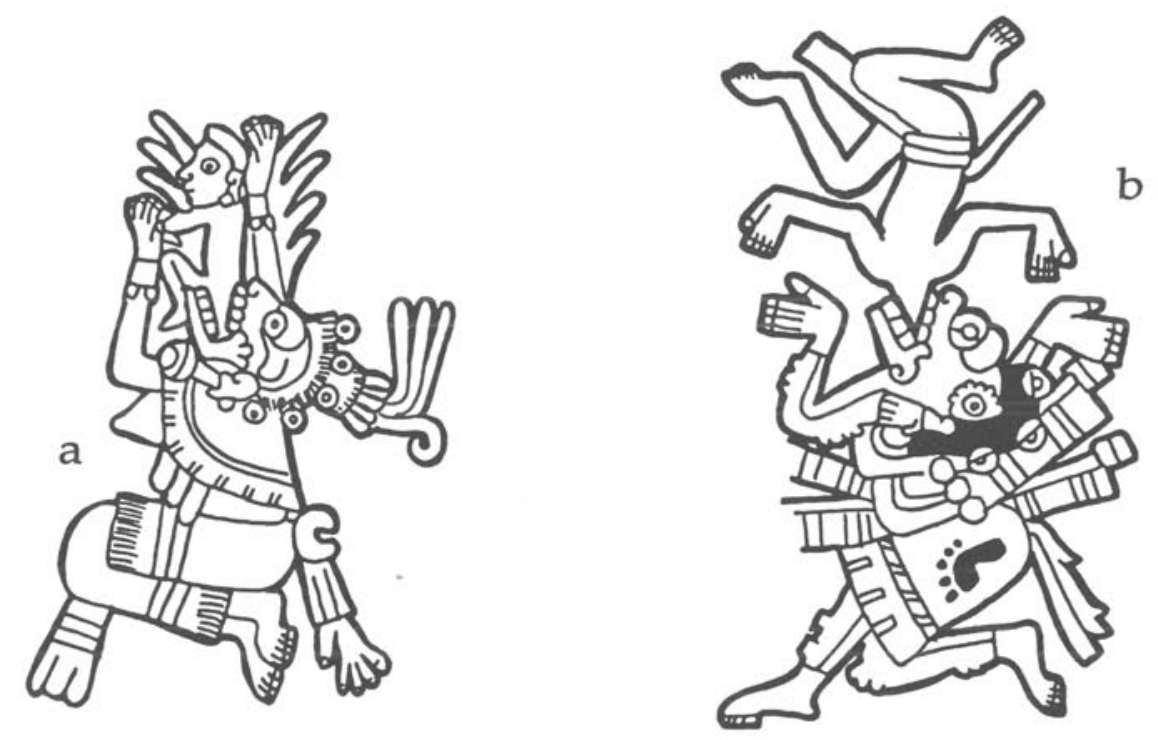

Figure 31: (a) Death goddess (Fejervary-Mayer 28). (b) Death goddess (Borgia 5).

Vindobonensis 28 shows 9 Grass at a ceremony in which 44 personages receive their personal names and insignia from the culture hero, 9 Wind (Furst 1982:215). She is wearing a quechquemitl with a serpent border. An additional black-and-white quechquemitl is depicted before her bearing a scroll pattern design together with a blood-drinking ear of personified 
maize. The scroll pattern is typical of other parts of her clothing in her various appearances throughout the pictorials. (22) The blood-drinking ear of maize probably stands for 9 Grass's personal name: neñe. Nene can mean either "blood" or "parched corn" in Mixtec (Arana and Swadesh 1965:96). Vindobonensis 15, which refers to objects, persons and rituals over which 9 Grass presides, also shows a descending man pouring cups of blood onto a cornfield.

The blood/corn symbolism is notable with regard to Borgia 53. The lower right-hand panel shows stalks of corn growing from the chest of a female-skeletal deity lying on her back and set into a "crocodilian earth" panel. Above her, two deities shed blood from their genitals with bone perforators. (23) The blood flows onto corn, thus promoting its life. The skeletal goddess falls within Spranz's (1973:83) Cihuateotl-Tlamatecuhtli or earth-mother deity category of costume and regalia.

The deity on the right of the corn is distinguished by a yellow face band and a white hand painted across his jaw. Seler (1963 II:88) identified him as Maquilxochitl, and he is diagnostic of Spranz's "Macquilli Series" of central Mexican deities (Spranz 1973:96-108). Personages bearing this deity's attributes are rare in Mixtec pictorials. Nevertheless, Vindobonensis 37 shows one ancestral male bearing Macquilli attributes emerging from the sacred birth tree.

The deity on the left bears the attributes of Ehecatl-Quetzalcoatl (Seler 1963 II:88). Quetzalcoatl is viewed as the idealized lord in the Postclassic Central Mexican, pantheon and one of his main diagnostics is the perforator which he often wears in his headdress or hair. In Mixtec pictorials like Vindobonensis, he is portrayed as a culture hero named 9 Wind, who on being born from a flint stone, descends from "Place of Heaven," institutes various rituals, and awards personal regalia to the founding ancestors and priests (see Nicholson 1978).

The Borgia scene therefore depicts an act of sacred reciprocity between the ancestral lords and the primal female earth deity. The lords demand corn and thus give the blood of their generative organs to the earth goddess, who then becomes the source of the blessed corn itself. Neither party can survive without the other. Considering this divine relationship, religious personages like 9 Grass could not have created more powerful forms of symbolism and ritual to enforce their sacred authority over the secular affairs of the lords.

\section{GRASS AS EARTH-MOTHER GODDESS}

Although the earth-mother goddess is comparatively rare in Olmec and Maya art, she was prominent in the Postclassic period throughout Central and Southern Mexico. To the Aztec she was known variously as Cihuacoatl, Coatlique, and Tlazolteotl. Caso proposed that these:

"three goddesses, who apparently are only three different aspects of the same deity, portrayed the earth in its dual function of creator and destroyed." (Caso 1958:53) 
Nicholson (1971) places these deities in the rain-agricultural-fertility section of his study of the Aztec pantheon. The goddesses are simultaneously the mother of the gods, patrons of childbirth, the personification of the earth, and consorts of the death god, Mictlantecuhtli. The Cihuacoatl, or "Serpent Woman," manifestation is of particular importance to his discussion. She is commonly portrayed in both sculptures and pictorials as a haggard woman with a skeletal head or jaw. She sometimes has twisted hair and claws for hands and feet. Nicholson (n.d.:5-16) believes that during the Aztec period her cult was extensive throughout the Valley of Mexico .

The Mexica erected a large temple in her honor within the main sacred precinct calling it Tlillan or Tlillancalco, "Place of Darkness" or "House of darkness." The temple was uniquely characterized in the Codex Borbonicus as having door jambs and a lintel upon which was painted a large maltese cross. Other temples and sacred structures associated with Cihuacoatl were similarly called Tlillan or Tlillancalco. The inner chamber contained a statue of the goddess; this room was always kept dark, and it had only a small door through which a person could barely crawl (Durán 1964: 179). The temple also played a pivotal role during accession ceremonies for the tlatoque, the Aztec emperors.

This last point is of particular interest in light of J. Rounds' (1982) study of the Mexica administrative hierarchy. Arguing that the Mexica had not formed any regulated system of succession for the paramount position of tlatoani, Rounds suggests that the interregnum could have been a very tense period in which dissension among the tetecuhtin, the aristocratic lineage heads, could temporarily upset the affairs of state. Rounds believes that the rulership position was seen in some way as the property of a corporate group rooted in the lineage of Acamapichtli, the first tlatoani. The fact that the throne tended to be passed among siblings, and not from father to son, reaffirms this. According to Round's, the Mexica seem to have maintained the political role of "stand-in" through a high priest known as the Cihuacoatl.

Durán (1964) states that Tlacaelel, Acmapichtli's grandson and the brother of Motecuhzoma I, instituted the position of Cihuacoatl and maintained it through the reign of three successive rulers. Following his death, the Emperor Ahuitzotl must have delegated the position to Tlacaelel's family, for both Tlacelel's son and grandson were Cihuacoatls. The Cihuacoatl was accorded considerable power. He not only managed the goddess' cult, which was a focus of accession rituals, but he was also the minister of war and maintained the affairs of state during the times when the tlatoani was away waging wars of conquest.

Interestingly, Ixtlilxochitl (1965 I:178, 193-194) states that the high priests of both Azcapotzalco and Texcoco were called Cihuacoatls as well. It seems likely that the source of both the cult and the administrative role was Culhuacan, where Cihuacoatl was the patron deity and where sources of Toltec lineage and legitimacy was originally based (see Nicholson n.d.). Durán (1971: 210) states that she was the patron deity of Xochimilco, and although the other Aztec states accorded much to her, Cihuacoatl was especially revered as a "national" deity in this town (see Klein 1988). Huitzilopochtli, Xiuhtecuhtli, and Tetzcatlipoca filled 
these positions at Tenochtitlan, Azcapotzalco, and Texcoco, respectively.

Evidently, the earth-mother cult was both ancient and widespread in Mesoamerica. Although it extended as far back as the Preclassic, its most prolific appearances occur in the Postclassic, especially in Central Mexico. Here she was known as Coatlique, Cihuacoatl, Tlazolteotl, 9 Grass, and a host of other avatars. The female-skeletal symbolism is representative of the Precolumbian perception of life and death as a cyclical process, and the two worlds were fused in displays of her regalia. Her cult was obviously important, as she was seen as the mother of the gods. In many instances her priests were the highest ranking officials in the state religion even though she did not always stand as the patron deity. (24).

Because her cult was involved with concepts of transition between the real and supernatural worlds, she was possibly viewed as a symbolic ideal for the transition of power in general. Hence it seems likely that, in the process of organizing the state religions with counterbalancing sacred and secular authorities, the emerging bureaucracy purposely sought to root their divine right of rule in the earth-mother cult. Tlacaelel specifically invoked this imagery in establishing his position. His successors even dressed as the goddess for important state ceremonies (Durán 1964: 230).

What is interesting is how two such different cultural traditions as the Aztec and Mixtec manipulated the same symbolism to suit the needs and functions of their particular bureaucracies. The Aztec were maintaining a centralized state with a single paramount ruling the capital of an expansive empire. The Mixtec, on the other hand, maintained a decentralized system of small territories. The powers attributed to the sacred realm of political authority differed concurrently. The Aztec Cihuacoatl was a powerful religious authority who complemented the tlatoani, an embodiment of the god Huitzilopochtli. In view of this complementary role, the selection of specifically Cihuacoatl imagery is understandable for the goddess was said to be Huitxzilopochtli's sister (Durán 1971: 217). There is not the slightest hint of complementary equivalency in power within the Mixtec system. 9 Grass operated as a superior being who played a decisive role in arbitrating marriages, alliances, and disputes.

The 8 Deer period is characterized by mysterious deaths, assassinations, and sacrifices that affected the Mixtec's ability to maintain their system of strategic marriage alliances. The consequent war of succession by ambitious persons could have escalated to the point where it was detrimental to the entire society, the least of which would have been an interruption of vital economic exchanges. It is precisely during such times that 9 Grass appears. In one sense, then, she represented a form of centralized authority and unification for the Mixtec. This authority rested in the maintenance of a funerary cult in which the principal ruling members of the main dynasties, though divided in life, were unified in death.

The very fact that the dead were mummified points to deliberate political decisionmaking by the oracles. The bodies of the dead could then be viewed as the actual artifacts of genealogical reckoning that supported the pictorial records. It is notable that according to 
current interpretations of the dynastic disputes, the remains of those who lose their rights to rule during the "War of Heaven" and 8 Deer periods are burned on pyres, not mummified (Zouche-Nuttall 4, 20, 81, 84). The finality of this act is confirmed in observations that any thought of cremating the body was, and still is, regarded with abhorrence (see Parsons 1936: 153). 


\section{4 JAGUAR: THE FOREIGN BENEFACTOR}

\section{OUTSIDE TITLES OF LEGITIMACY}

Throughout this approach to the political disposition of the codices, the factional nature of Mixtec social structure has been continually emphasized. In Chapter II, it was proposed that salient characteristics in Mixtec political systems become especially pronounced during periods of conflict. Some anthropologists (M. Fortes and E. E. Pritchard 1975:14-15, 242) have suggested that patterns of limited armed conflict in some cultures may even insure a degree of stability through time, by permitting the release of built-up social tension within the political structure. Warfare at this level rarely escalates because,: first, the competing groups have probably become fairly evenly matched through time; second, they share particular interests within a field of common values (such as land, kinship relations, same religious dogmas, and common mythic origins); and third, the risk of attrition could affect both groups in an equally harmful way. There is no gain other than the expression of grievance, and, generally, both sides resume their normal relations.

However, the over eighty conquests listed in the Codex Zouche-Nuttall (43-83) indicate that more than small armed disputes characterize 8 Deer's rise to power. 8 Deer is clearly enforcing his will on other dominions, and it is proposed here that this was necessary because he was the usurper to a title for which he had little, if any, blood claim. He finds himself in direct conflict with the "field of common values" held by the established dynasties, and therefore his power must be derived from groupings other than those generally recognized by the lineage-based system purportedly regulated by oracular priests like 9 Grass.

Abner Cohen proposed that instead of viewing such kinship groups and the symbolic ideology that binds them as the sole political actuality, one should look for power groups in general, whether they are officially recognized or not.

"If we operate in terms of power groups, instead of classes, we shall be able to solve such theoretical problems as those posed by cases of incongruity between status and power" (Cohen 1976:124).

Given the incongruity between status and power in 8 Deer's case, what sources for the formulation of outside power groups would have been available to him? We have examined his use of kinship ties to organize the priesthood, his meetings with allies, and his consultation with divine oracular authorities. Now we will examine assistance and titles of legitimacy from foreign sources.

Codex Bodley 6I indicates that the last lord of Tilantongo's first dynasty, 2 Rain Ocoñaña, died mysteriously in the year 6 Flint (See Appendix). Following Rabin's (n.d.a., 
n.d.b.) revised chronology, Lord 8 Deer then attacked Hill of the Moon in the following year, capturing Lord 3 Crocodile. Codex Selden 7-8 indicates that 3 Crocodile was an ally of Lady 6 Monkey who had aided her in the conquest of the same place six years earlier.

On Bodley 10 II, 8 Deer presents the captive 3 Crocodile to Lord 4 Jaguar who is seated at Tula Place. Directly following this presentation, Lord 4 Jaguar pierces the septum of 8 Deer's nose, ritually awarding the Mixtec lord with a turquoise nose ornament called, in Nahuatl, the yacaxiuitl (Caso 1960:39) (Fig. 32). Both Alfonso Caso (1960: 39, 1966) and Nancy Troike (n.d.b.: 199-200) have described this event as a critical turning point in the 8 Deer saga, that marking the beginning of the hero's rise to power to become founder of a new dynasty at Tilantongo (Troike n.d.b.). It appears, therefore, that Lord 4 Jaguar was a powerful oracular benefactor for at least some Mixtec kings, in a way not dissimilar to 9 Grass.

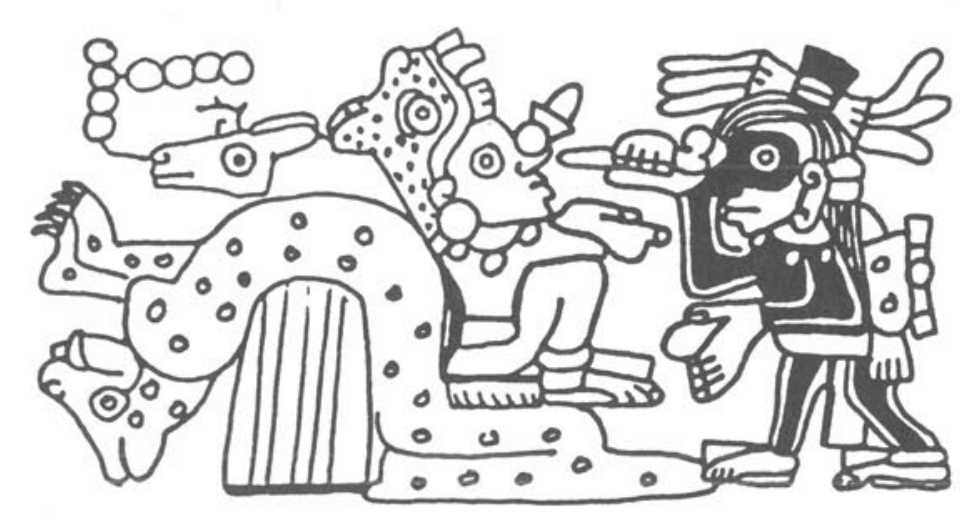

Figure 32: 8 Deer receives the yacaxihuitl nose ornament, transforming him into a tecuhtli or lineage head (Bodley 9II).

The precise identification of Lord 4 Jaguar has been a challenge to nearly all scholars of the Mixtec codices (Caso 1960, Jansen 1989). Despite his prominent role in the 8 Deer and 4 Wind stories, his parentage is never shown. There are no birth, marriage, or death dates listed, nor does 4 Jaguar appear in the deity lists of Codex Vindobonensis obverse. The place sign with which he is associated is composed of a frieze with "tule" or cattail plants as qualifiers, but this place sign configuration could easily refer to any number of "Tulas" or "Tollans" located throughout Mexico. For example, Tula-Hidalgo, Cholula, and Tenochtitlan were all "Tula" places.

One clue to 4 Jaguar's identification is found in a set of costume attributes worn by both the oracle and the priests whom he directs. He most often appears dressed as the impersonator 


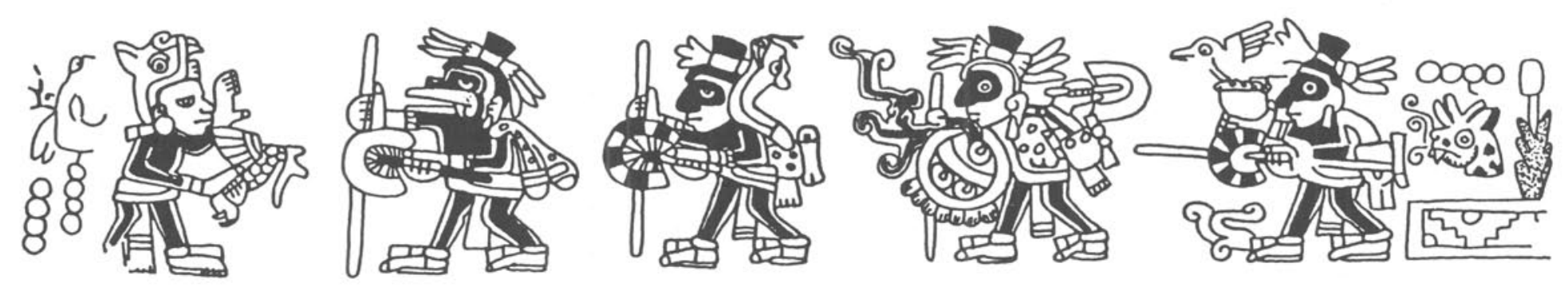

Figure 338 Deer venerates four priests carrying the staffs and fans of merchant-ambassadors. They are sent by 4 Jaguar of "Tula" place. (Bodley 10III). 
of the patron deity of the Tolteca-Chichimeca, Tetzcatlipoca-Camaxtli-Mixcoatl. Since these attributes do not mark a specific political office, clearly some form of ethnicity is being communicated, relating 4 Jaguar to the Nahuatl alliances of Tlaxcala and Puebla (Fig. 33).

To examine this hypothesis, we must review evidence not only from the Mixtec codices, but also from the histories of Pueblan kingdoms depicted in the Historia Tolteca Chichimeca, the Mapas de Cuauhtinchan, and an important corpus of 16th-century Inquisitorial documents involving native priests who claimed to be the reincarnations of the God Camaxtli-Mixcoatl (Kirchhoff et al. 1976, Reyes 1977). We will also examine the lienzos of the Coixtlahuaca group which portray the northern confederation of Mixtecs who claimed Tolteca-Chichimeca descent (Caso 1961b, Parmenter 1982).

\section{CASE STUDIES}

\section{JAGUAR AND 8 DEER}

4 Jaguar appears eleven times on Zouche-Nuttall reverse in conjunction with the 8 Deer story. On page 52, 8 Deer makes a pilgrimage to visit 4 Jaguar (Fig. 34). He is accompanied by his younger brother 9 Flower, who is dressed as one of the four councilor-priests and who carries the heraldic "venus" staff so often associated with the sacred bundle. 4 Jaguar receives 8 Deer, presenting him with a quail, an act of veneration. Between 4 Jaguar and 8 Deer sits a cloth draped pedestal bearing 8 Deer's sacred bundle. In the following scene, cognate to that in Bodley 9 II, 8 Deer is shown lying upon a jaguar skin, having his nose pierced by another priest. On page 53, 8 Deer presents a quail to 4 Jaguar. He now wears the turquoise yacaxihuitl ornament of a Nahuatl tecuhtli or great lord.

The same event is portrayed in Codex Colombino 13 II/III. After appearances of 4 Jaguar meeting with personages whom Troike (n.d.b.: 167) identified as his mediators, 8 Deer again lies upon a jaguar skin. One man pierces the septum of 8 Deer's nose, while another holds the yacaxihuitl turquoise ornament. As in Bodley $9 \mathrm{II}$, "Tula" is given as the location of the event (Caso 1960: 39).

Following the awarding of the nose ornament, 4 Jaguar participates in a military campaign with 8 Deer in both Zouche-Nuttall 70-75 and Colombino-Becker. Eventually, their partnership leads them to an encounter with the solar deity 1 Death, a personage I have identified elsewhere as the oracle of Achiutla described by Burgoa (1934 I: 318-320, 332) (See Caso 1959, Byland and Pohl: in press). On Zouche-Nuttall 75 through 78, 8 Deer and 4 Jaguar first cross a river or lake in canoes. Next they battle supernatural warriors and take captives, at least two of whom, 7 Flower and 4 Movement, had died at an earlier time according to the obverse of the codex on page 4 . Thus the event has a distinctive, otherworldly dimension. 
Figure 34 : 4 Jaguar (Zouche-Nuttall 52).

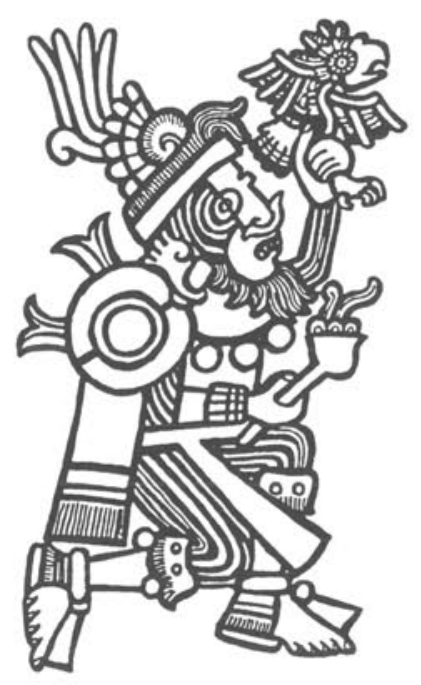

On Zouche-Nuttall 78, 8 Deer and 4 Jaguar meet with the oracle of Achiutla, 1 Death. They present him with precious gifts of jewelry and drill new fire. On page 79, 8 Deer and 4 Jaguar are directed by 1 Death to Place of Heaven where they meet at a celestial opening, perhaps a cave.

After another crossing of water in a canoe and one last meeting, 4 Jaguar disappears from the Zouche-Nuttall account. Lord 12 Movement, 8 Deer's half-brother, is subsequently assassinated, and 8 Deer goes to war against Red and White Bundle between pages 83-84. Codex Colombino-Becker also details the encounter with the oracle 1 Death, featuring 4 Jaguar prominently between Becker 1-5. Codex Bodley does not mention 4 Jaguar after the awarding of the yacaxihuitl.

\section{JAGUAR AND 4 WIND}

4 Wind "yahui," the son of Lady 6 Monkey of Jaltepec and Lord 11 Wind of Red-andWhite Bundle appears only once on Zouche-Nuttall 83 as 8 Deer's captive. The events in his life after this encounter are detailed in Colombino 16, Becker 14-16, and in Bodley reverse 34-29 (Troike n.d.b., Caso 1960). Through an analysis of Colombino 16, Troike (n.d.b.: 356) has shown that 4 Wind was involved in 8 Deer's assassination (See Appendix). Bodley 34 IV indicates that three years after 8 Deer's death, 4 Wind traveled to "Serpent Place" or Coixtlahuaca (Caso 1960: 60), where two men present him with a distinctive black-and-white checked shirt and a hunting bow. Both men are dressed like 4 Jaguar, including the wearing of distinctive black face paint.

Bodley 34 III shows that 4 Jaguar then pursued and attacked 4 Wind, while carrying a distinctive Toltec weapon, the macuahuitl or obsidian-edged club. The dispute, which involved 4 Wind's participation in 8 Deer's assassination (Troike n.d.b.: 397), was apparently 
He and his assistants wear the costume of the Tolteca-Chichimeca culture hero CamaxtliMixcoatl. They act simultaneously as priests, ambassadors, and merchants.
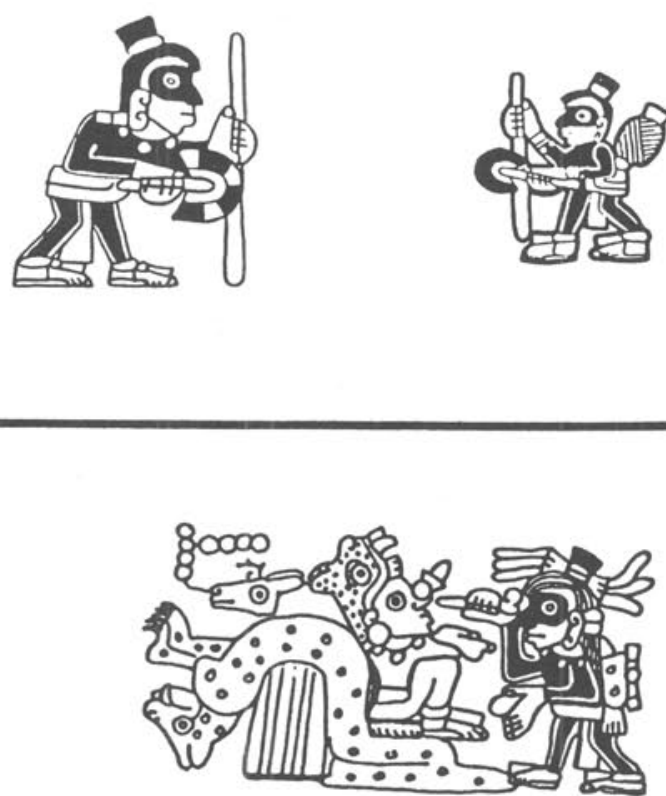

He awards the yacaxihuitl nose ornament by which a lord is transformed into a tecuhtli or lineage head.
He and his assistants are associated with the "Tula" place sign standing for San Miguel Tulancingo, Coixtlahuaca

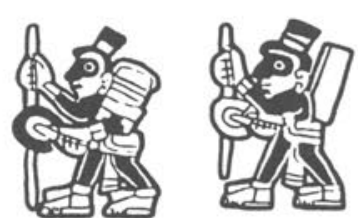

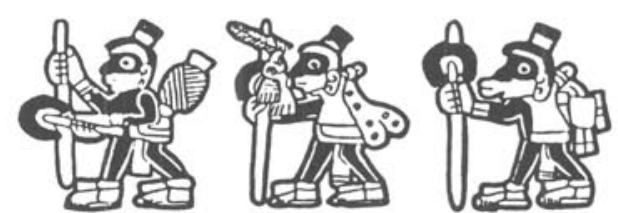
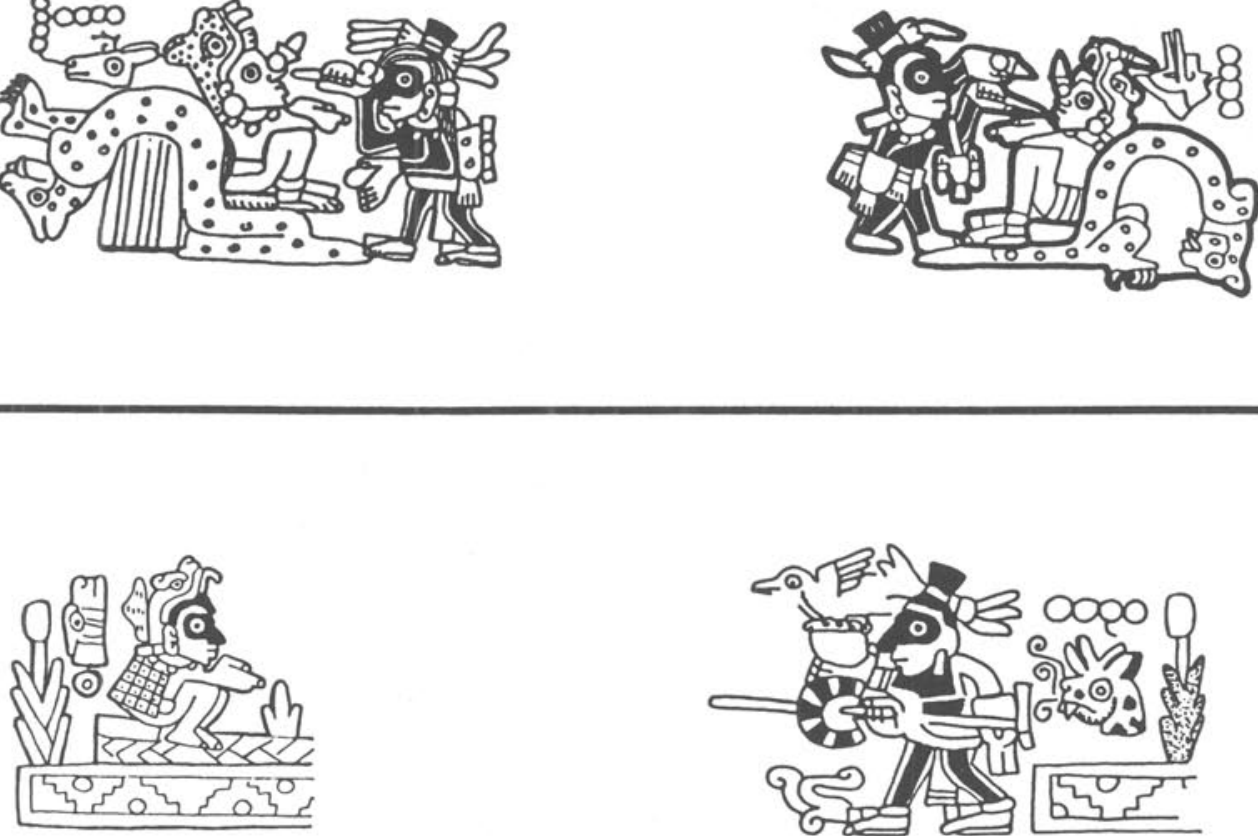

BEHAVIORAL CHARACTERISTICS OF THE DEITY-IMPERSONATOR 4 JAGUAR 
also resolved through the mediation of the oracle 1 Death. On Bodley 33 I, 4 Wind journeys to Tula. Like his predecessor 8 Deer, he is awarded the yacaxihuitl nose ornament by 4 Jaguar. On page 32 III, 4 Wind leaves Tula escorted by five of 4 Jaguar's assistants carrying the staffs and fans of merchant-ambassadors. He is then installed as lord of Place of Flints. He subsequently marries 8 Deer's daughter Lady 10 Flower, thereby uniting his royal house with that of Tilantongo.

To summarize, both 8 Deer and 4 Wind have similar experiences through their interaction with Lord 4 Jaguar. Like Lady 9 Grass, 4 Jaguar appears at critical periods of political transition, aiding lords wishing to establish themselves in positions to which they have no divine right through the genealogical reckoning of the codices. With the award of the yacaxihuitl, Lord 4 Jaguar first helps Lords 8 Deer and 4 Wind achieve a transformation in status. He then arranges a special meeting with the oracular solar deity, 1 Death (See Chart 4).

Like the oracles 9 Grass and 1 Death, Lord 4 Jaguar had an abnormally long life-span indicating that his appearance in the codices documents a high religious office occupied by a priestly deity-impersonator, and not the life of a single individual. Unlike 9 Grass and 1 Death however, he is extremely "mobile". Mixtec lords and ladies do not simply go to him to petition his favor. Rather he is just as likely to come to them (see Troike n.d.b. 188-202; 380-390). Lord 4 Jaguar behaves more as an equal whereas the Earth Goddess 9 Grass and the Solar God 1 Death almost always appear seated on thrones before elaborately decorated shrines; and rulers who petition them appear kneeling or seated in inferior circumstances,. He journeys to the various kingdoms, formulates alliances, personally inserts the tecuhtli ornament into a lord's nose, and wages war, all as personal feats in the manner of powerful princes.

Finally, Lord 4 Jaguar and his adjutants also display the symbolism indicative of merchants (Fig.33). This is clearly shown by the appearance of walking staffs and fans in all of their most important appearances (Colombino 11I, 12II, Becker I: 15III, Bodley 10III, 33II, 32III) (See Fray Bernardino de Sahagún's Florentine Codex Book 9: The Merchants, Codex Mendoza Folio 66r). We know from studies of the roles of the later Aztec merchants, the Pochteca, that they not only served as traders but also as priests, spies, ambassadors, and even battlefield commanders (Bittman and Sullivan 1978). Codex Borbonicus 33 portrays a figure of the culture hero Camaxtli-Mixcoatl whose garb 4 Jaguar wears. Significantly it is glossed Dios del Tianguiz or "God of the Market Place."

\section{THE NOSE ORNAMENT CEREMONY}

The significant aspect of 4 Jaguar's role in Mixtec affairs lies in the yacaxihuitl ritual itself. The ceremony is not of Mixtec origin, but rather associated with a title granted to Tolteca-Chichimeca noblemen of the Pueblan-Tlaxcalan city-states during the Early Postclassic period (See Kirchhoff et al 1976: 171-172, Carrasco 1966). No king in the Mixtec 
codices is shown wearing the device prior to 8 Deer, although many of his descendants display it. The ornament is often painted blue in the pictorials, indicating that it was made of turquoise. It is formally composed of a circular base with a triangular point. It was inserted through the septum of the nose, where it either projected out from the face or hung down to the mouth. Caso (1960: 39) first identified the ornament in the Mixtec codices as the symbolic manifestation of the title tecuhtli or "lineage head" (plural tetecuhtin) (Carrasco 1966:134135, Rounds 1977).

We know of the rites for initiating a tecuhtli from accounts of the oracular shrine of Cholula, renowned for its cult dedicated to the Nahuatl gods Camaxtli-Mixcoatl and Quetzalcoatl. Their shrines were venerated as a New World "Mecca" by Central Mexican, Pueblan, and Oaxacan communities as far south as Tehuacan, Coxcatlan, and Teotitlan del Camino (Rojas 1927, Carrasco 1966, Lind n.d.). The candidate for the title generally applied through mediation between his parents and two powerful Cholula priests called the Aquiach or sky lord and the Tlachiach or "earth lord". According to Motolonía (1903:286-292), an eligible prince accompanied by his parents, allies, and other tetecuhtin met with the high priests in the "house of the principal demon" Camaxtli Mixcoatl, the culture hero of the Tolteca-Chichimeca and the father of Ehecatl-Quetzalcoatl.

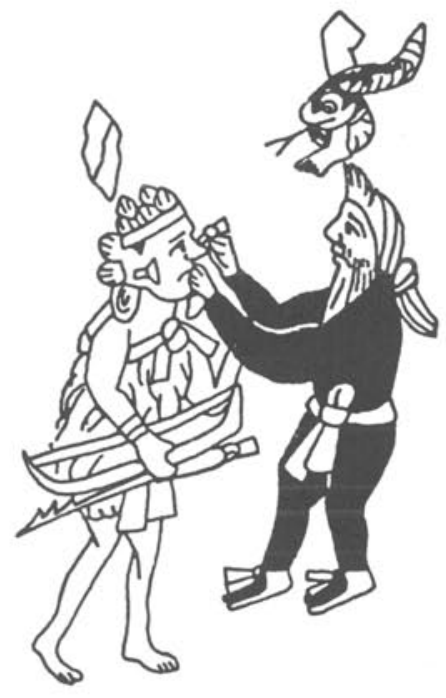

Figure 35: A Chichimec lord is transformed into a tecuhtli by the Tlachiach of Cholula (Historia Tolteca Chichimeca, Folio 21r).

After several days of prayer and penitence, the ears, nose or lips of the initiate were pierced with sharpened jaguar and eagle bones, and an ornament was inserted according to the custom of the kingdom from which the petitioner came (Rojas 1927: 161) (Fig. 35). Upon being 
declared a tecuhtli, the prince returned home, escorted by five agents of the Cholula priests to confirm his divine right to rule a teccalli, or noble estate, as "lineage head." The shrine purportedly dedicated to Camaxtli Mixcoatl is portrayed in the Historia ToltecaChichimeca, Folio $21 \mathrm{r}$. Within a rectangular structure two Chichimec chiefs who had emerged from the sacred caves of Chicomoztoc with Camaxtli Mixcoatl, are shown having their noses and lips pierced by the Aquiach and Tlachiach. Comparing this scene to a diagram of the Cholula religious precinct in the Mapa de Cuauhtinchan II, Michael Lind (n.d.) proposed that the confirmatory chamber was located adjacent to the great temple of Quetzalcoatl itself.

According to Pedro Carrasco (Carrasco et al 1971: 352-354, 1976), the title of tecuhtli transformed a prince into the head of an Aztec teccalli or noble house, a patrimonial landed estate worked by commoners who paid tribute. The title was held for life, with a successor often, although not necessarily, being elected from among the tecuhtli's sons by consent of the highest ranking members of the royal house. The position has perplexed scholars because of the variety of applications of the term tecuhtli to judges, merchants, members of elite military orders, and so on, possibly indicating distinct types of tetecuhtin. More likely, certain noblemen were deemed to be the most qualified to hold these positions because they also held the title of tecuhtli (Rounds 1977).

Merecedes Olivera (1978) examined the role of the tecuhtli in Tlaxacalan and Pueblan kingdoms in the vicinity of Cuauhtinchan (Fig. 36). She proposed that the position was fundamental to elite social ranking and territorial organization. The estate of a tecuhtli consisted not only of a class of commoners bound to work the noble's lands but also lesser ranking princes, pipilitin, who served as administrators. The highest ranking tecuhtli was named tlatoani. According to the Lienzo de Tlaxacala, the most powerful Tlaxcalan polities were ruled by a tlatoani together with as many as 52 tetecuhtin.

Pedro Carrasco (1974:7) examined the role of the tetecuhtin of Huexotzinco by using the Matrícula de Huexotzinco. He proposed that the position provided a focal point for internal ranking within the kingdom, as lesser nobility reckoned subordinate lines either through direct descent from a tecuhtli or through some other special relationship with the royal house. J. Rounds (1977: 348 ) proposed that, just as the pipiltin were ranked according to some special relationship with the tecuhtli, so the tetecuhtin could be similarly ranked with regard to their kinship relations with the tlatoani:

"We may see from this analysis that the administrative structure was based on a nesting of similar units, each of which had an internal hierarchy and which, as a unit, had a determined place in the overall hierarchy. As in most emerging states, this simple political system was based on the replication of a basic unit at successively higher levels of organization."

In many respects the role of the tecuhtli resembled that of the yya or Mixtec king. 


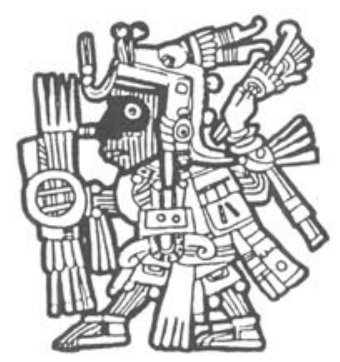

LIENZO DE TEPETICPAC
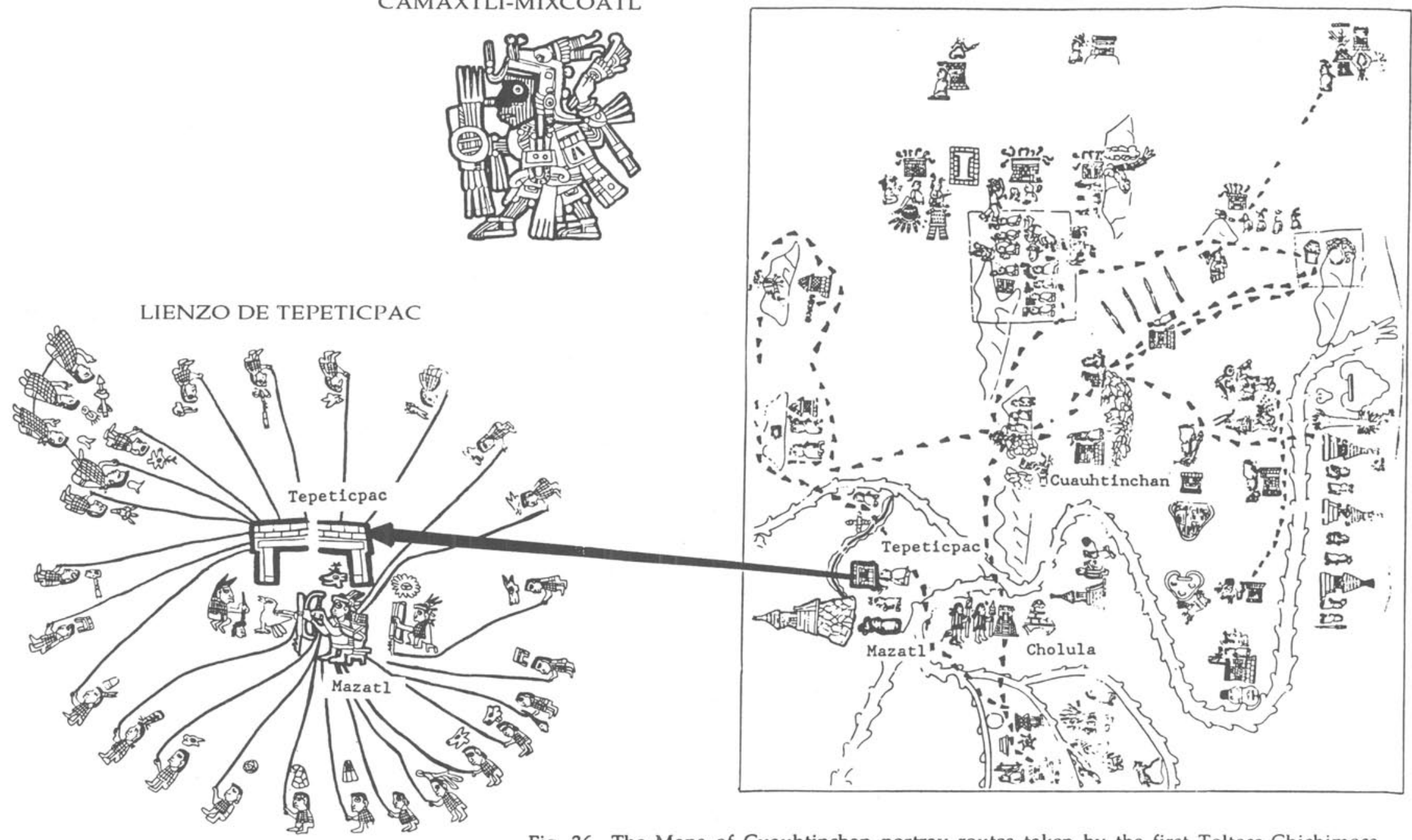

Fig. 36 The Maps of Cuauhtinchan portray routes taken by the first Tolteca-Chichimeca ancestors after their emergence from the caves of Chicomoztoc. Their leader was the god Camaxtli-Mixcoatl also known as Mazatl or Mazatzin (Davies 1977:357). The maps also indicate the establishment of the first teccalli or royal estates such as the Tlaxcalan capital of Tepeticpac. The Lienzo de Tepeticpac portrays the same event but details various social relationships held by lesser ranking tetecuhtin either with the teccalli itself or its founder Lord Mazatl (Camaxtli-Mixcoatl?). 
Both the yya and the tecuhtli could claim a paramount position by virtue of descent. Descent reckoning also led to the creation of lineage hierarchies. Nevertheless, among the Mixtec, primogeniture was the preferred system for passing the paramount position from one generation to the next. The Mixtec codices indicate that kings gained titles by reckoning direct descent from various divine ancestors born from trees, caves, and other features.

The Tolteca-Chichimeca on the other hand appear to have "elected" the tecuhtli or "lineage head," with only special consideration being given to a favored son. The royal descent group in general claimed its position through some explicit, though not necessarily genealogical, connection to either a "son" or follower of the culture hero Camaxtli-Mixcoatl, who emerged from the seven caves of Chicomoztoc (See Motolinía 1903: 9, 1951). This implies that the title of tecuhtli could also represent a fictive kinship term, explaining the absence in the Historia Tolteca Chichimeca and the Mapas de Cuauhtinchan of genealogical descent lists typical of the Mixtec codices. Emphasis in these documents is on a legendary migration saga that led to the establishment of the principal teccali as political units and not on the patrilineal descent reckoning of individual kings.

The suitability of a noble title, even a foreign one, bearing the connotations of head of a royal lineage and conferred by election would have held considerable attraction for a lord like 8 Deer who lacked a legitimate claim to the throne of Tilantongo by Mixtec rules of descent. We have seen that his transformation through the adoption of the tecuhtli title also secured him a powerful military alliance with the priest 4 Jaguar.

\section{COSTUME AND REGALIA}

Besides his affiliation with the yacaxihuitl ceremony, Lord 4 Jaguar is distinguished by the wearing of special costume and regalia that connect both him and his acolytes to the primary religious cults of the Tolteca-Chichimeca. Since the majority of these personages are associated with a single location, "Tula," their costume also marks them ethnically. Indeed, a term for "Mexican" (a man from northwest or the Valley of Mexico) in the Alvarado dictionary (1962: 149b) is tay nuu coyo meaning "People from the Town of Cattails", in other words "Tula."

In Codex Zouche-Nuttall 4 Jaguar's costume is varied. Nevertheless, there are certain items of clothing that specifically associate him with three deities from the Central Mexican pantheon: Tetzcatlipoca, Camaxtli-Mixcoatl, and Tlahuizcalpantecuhtli whose attire can be virtually identical to that of Camaxtli (See Spranz 1973: 181-205, 116-126) (Fig. 37).

On Zouche-Nuttall page 52, 8 Deer meets with 4 Jaguar for the first time. Affixed to the priest's collar is the distinctive "mirror" bound in red-and-white leather and worn by Tetzcatlipoca throughout the Borgia group codices (Spranz 1973: 196). Black-and-gray striped paint on the arms and legs is diagnostic of Tetzcatlipoca as well (see Codex Tudela Folio 15). The Chichimec buckskin bracelets and anklets, however, are diagnostic attributes of Camaxtli- 

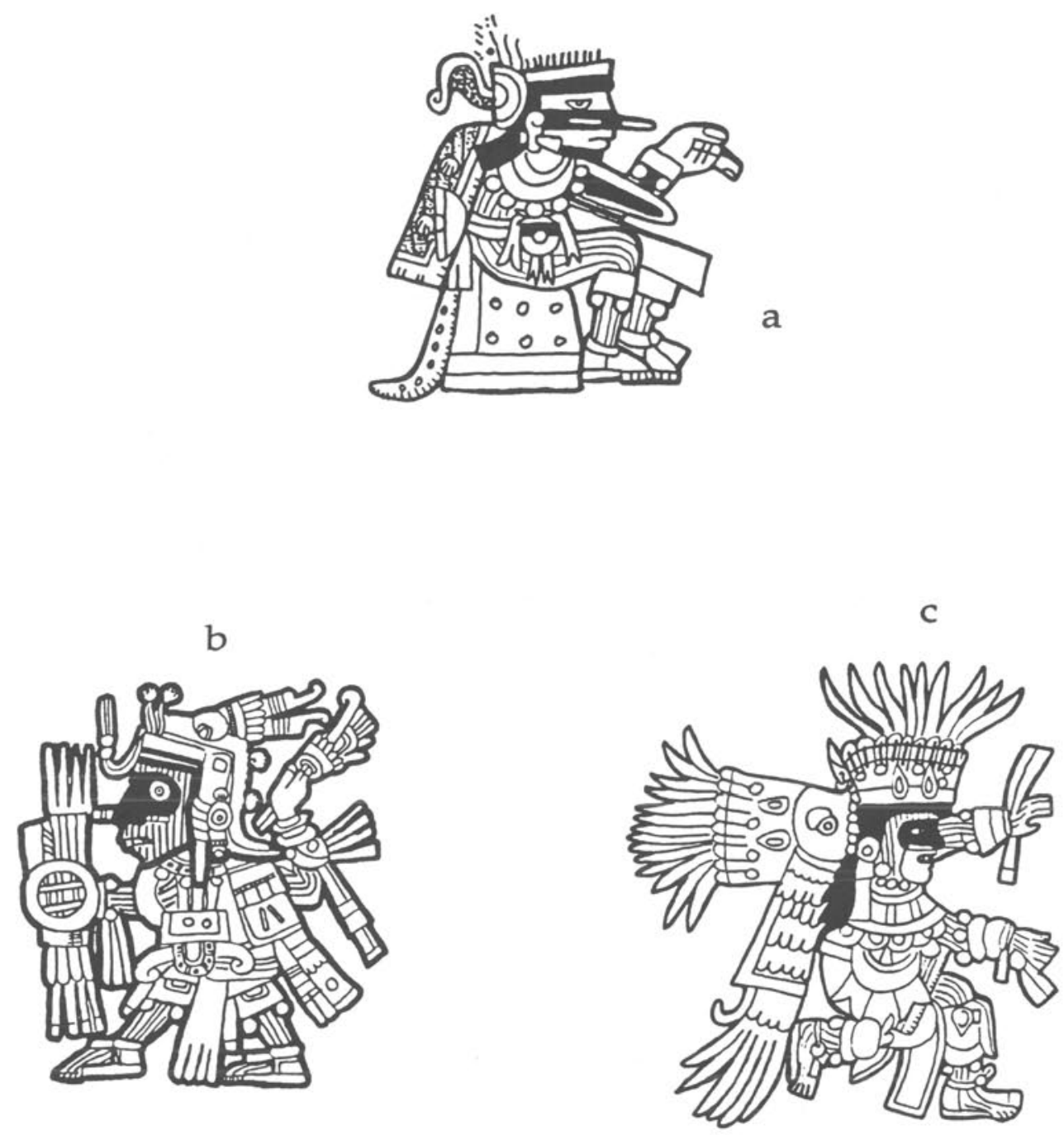

Figure 37: (a) Tetzcatlipoca (Cospi 86). (b) Camaxtli-Mixcoatl (Borgia 25).

(c) Tlahuizcalpantecuhtli (Vaticanus A).

Mixcoatl (Spranz 1973: 123-124). Throughout the remainder of Zouche-Nuttall reverse (pages $53,70,75,77,78,79$ and 80 ), 4 Jaguar appears most commonly in white body paint or wearing combinations of either the black-and-gray striping of Tetzcatlipoca, or the red-and-white 
striping of Camaxtli-Mixcoatl and Tlahuizcalpantecuhtli (Spranz 1973: 246-262). The buckskin bracelets are always worn. In Colombino 9-13 and Becker I 15-16, the attributes of Camaxtli-Mixcoatl worn by 4 Jaguar are manifested through both the wearing of red-andwhite striped body paint and distinctive black facial painting (Spranz 1973: 117). In Codex Bodley 9-10 and 34-32, 4 Jaguar and his assistants wear the distinctive black face paint of Camaxtli-Mixcoatl and black body painting.

In summary, the iconographic evidence clearly indicates that 4 Jaguar and his men maintained an affinity with the Tolteca-Chichimeca culture hero, Camaxtli-Mixcoatl as well as with the omnipotent Teztcatlipoca. The two deities may even have been worshipped as the same supernatural being. The Historia de los Mexicanos por sus Pinturas (Garibay 1979: 23 33) states that Tetzcatlipoca was also known as Camaxtli, and that he changed his name to Mixcoatl before drilling the fire for the creation of a new "sun." 4 Jaguar's name in turn is derived from a title born by Tetzcatlipoca after the first epoch or world creation, called 4 Jaguar, a time during which the deity presided as the "sun" (Caso: 1958).

The black facial paint as an ethnic attribute of Tolteca-Chichimeca priests is attested in a famous legend about Camaxtli-Mixcoatl and recorded in a number of Central Mexican sources (See Graulich 1974). According to the Leyenda de los Soles (Velázquez 1945: 122), the sun was created at Teotihuacan through the self-sacrifice of a god. However the sun did not move in the sky until Tlahuizcalpantecuhtli, the morning star, shot it with an arrow. 405 warriors called the Mimixcoa were then created to serve the sun by providing it with sustenance in the form of human hearts and blood (Historia de los Mexicanos por sus Pinturas, Garibay 1979: 36).

According to the Anales de Cuauhtitlan (Velázquez 1945: 3), the Mimixcoa were then called upon to guide the Chichimec people from Chicomoztoc to their new homeland in the Valley of Mexico. Along the route they were attacked by a ferocious demon called Itzpapalotl, the obsidian butterfly. She devoured all but one of the Mimixcoa, Camaxtli-Mixcoatl. He hid himself and then returned, succeeding in killing the demon and freeing his brothers. The Mimixcoa then burned her body and rubbed her ashes around the eye sockets of their faces to commemorate the event. The Mixtec consequently also called the Tolteca-Chichimeca the Sami Nuu or "people with burnt faces" (Alvarado 1962: 149b) (See also Smith 1973a:209, Jansen 1989 for discussion).

Motolonía (1903: 9-10) said that Camaxtli-Mixcoatl was born from the seven caves of Chicomoztoc. His wife, Ilanque, engendered six sons who in turn became the patriarchs of six great nations. These were named Xelhua, Tenoch, Olmecatl, Xicalancatl, Mixtecatl, and Otomitl. Camaxtli-Mixcoatl later married a second woman named Chimalma. She gave birth to the legendary Quetzalcoatl. According to Torquemada (1943 I:32), Motolonía (1903: 10), and the Relación de Acatlan (Acuña 1985a: 36), the fifth son of Ilanque, Mixtecatl, founded a dynasty at Acatlan in the Mixteca Baja (See Map 2). To the Tolteca-Chichimeca the $\tilde{n} u u$ dzahui or "people of the rain god" thus became known by the eponym "Mixtec" or "cloud 
people" as well.

The Codex Egerton (Sánchez Solís) (See Smith 1973a: 57, 61) lists prominent marriages between Tilantongo and Acatlan. A number of the male marriage partners in the manuscript wear the black facial paint of the Tolteca-Chichimeca. Acatlan, however, is represented in Egerton as Hill of the Jewel and not by a cattail frieze representing "Tula" (Smith 1973a: 61). On the other hand, another powerful Mixtec kingdom that claimed Tolteca-Chichimeca heritage was Coixtlahuaca, and a pre-eminent kingdom under its domination was called San Miguel "Tulancingo" or the "little" Tula place.

\section{SAN MIGUEL TULANCINGO AS "TULA"}

Since Clark (1912), Mixtec scholars have long noted the uniqueness of the yacaxihutil ceremony in both the 8 Deer and 4 Wind stories. They have all described the diagnostic place sign, usually a town ( $\tilde{n u u}$ ) substantive with a "cattail" plant qualifier (Smith 1973a: 70-75). Caso $(1960,1966)$ began calling the location simply "Tula" or "Place of Cattails" throughout his commentaries, while at the same time trying to avoid equating it with the great Toltec capital of Tula/Tollan in Hidalgo.

Caso discussed the significance of the nose ornament with regard to Cholula, Puebla (Caso 1960: 128-129). Cholula was also known as Tollan Cholulan, and place signs depicted in the Relación de Cholula and the Historia Tolteca-Chichimeca include the cattail plants as qualifiers (Smith 1973a: 70-74). More recently, Maarten Jansen (1989) has revived the identification of "Tula" as being Tula-Tollan, the great Tolteca-Chichimeca capital in Hidalgo. The very localized nature of early Mixtec codical history (Pohl and Byland 1990, Byland and Pohl: in press) that includes the lives of Lords 8 Deer and 4 Wind, points instead to a Tula lying somewhere near the Nochixtlan Valley. The implication of this observation is that while Lord 4 Jaguar acts very much like the Aquiach and Tlaquiach of the great oracular shrine of Cholula, he is also able to transport the cult of Camaxtli-Mixcoatl and its associated rituals of the tetecuhtin to the Mixteca Alta.

M.E. Smith (1973a) first proposed the identification for 4 Jaguar's "Tula" as San Miguel Tulancingo, a powerful kingdom that was subject to Coixtlahuaca. In the Lienzo of Coixtlahuaca, the Codex Meixueiro, Seler II and the Lienzo de Tlapiltepec, the community's place sign is identifiable as a temple platform with a cattail frieze motif. The Lienzo de Tlapiltepec (Smith 1973a: 244) depicts Coixtlahuaca's place sign as a stone or rock with two serpents intertwined around it. Adjacent to the Coixtlahuaca place sign are depicted a temple and a pyramidal platform that are qualified with the cattail plants standing for San Miguel Tulancingo (Smith 1973a: 72-74, Parmenter 1982) (Fig. 38). By comparison, Codex Bodley 34 IV depicts 4 Wind meeting with two of 4 Jaguar's priests, both of whom wear the black Camaxtli- 
Mixcoatl face mask. The event takes place shortly before 4 Wind receives the nose ornament at "Tula" from 4 Jaguar.
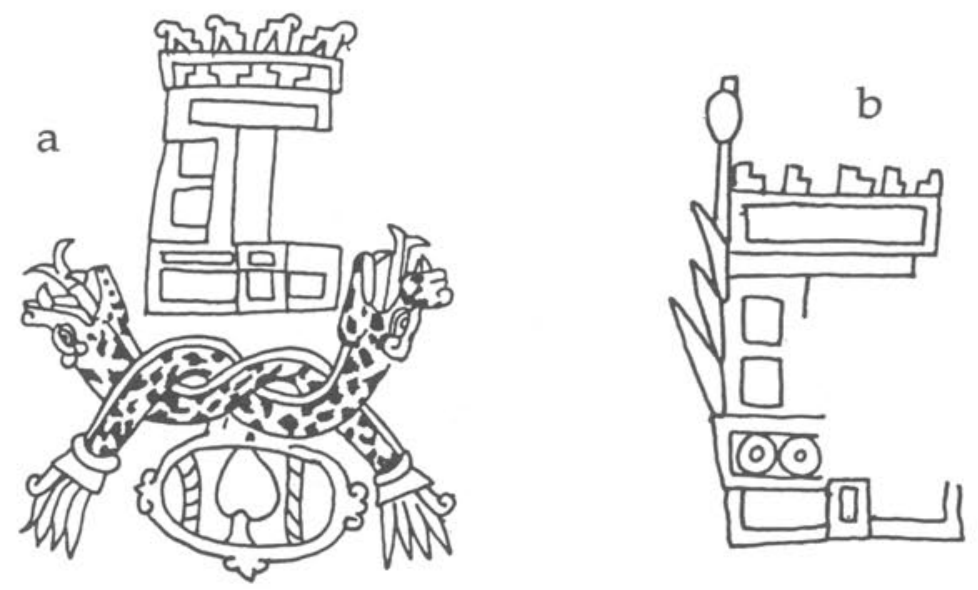

Figure 38: (a) Place sign of Coixtlahuaca on the Lienzo de Tlapiltepec. (b) Place sign of San Miguel Tulancingo on the Lienzo de Tlapiltepec.

The place sign with which the priests are associated compares favorably with the serpent rock configuration representing Coixtlahuaca in the Lienzo de Tlapiltepec (Fig 39). The two Bodley place signs considered together within the context of the 4 Wind story therefore correlate with the identifications that have been made for Tulancingo and Coixtlahuaca in the lienzos and manuscripts of the Coixtlahuaca corpus.
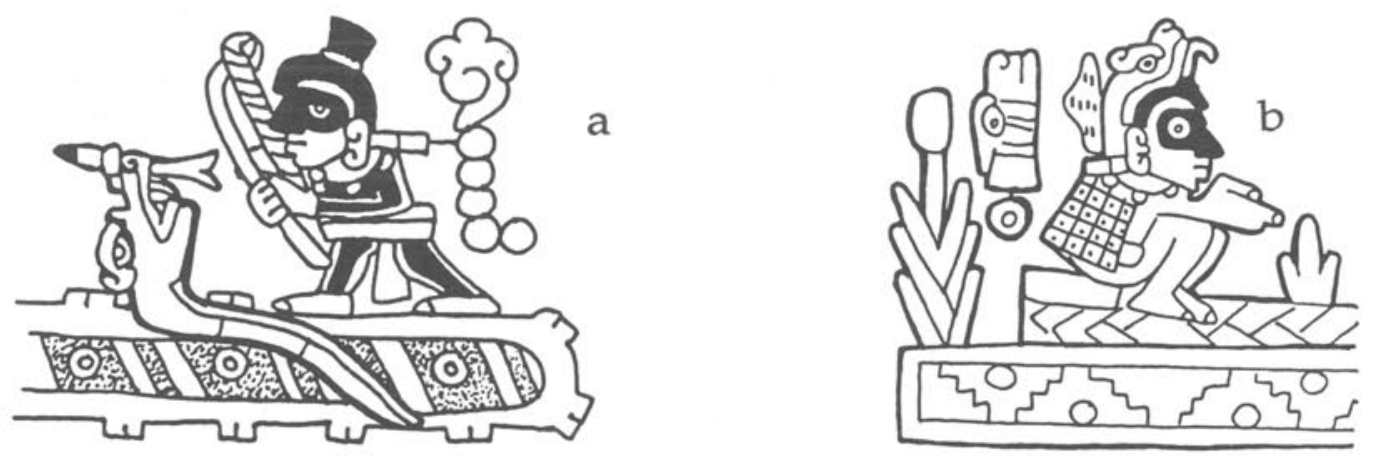

Figure 39: (a) Man with Camaxtli-Mixcoatl face paint at the place sign of Coixtlahuaca (Bodley 34 IV). (b) Man with Camaxtli-Mixcoatl face paint at the place sign of San Miguel Tulancingo (Bodley $14 \mathrm{II})$. 
Although somewhat damaged, Becker I 14I depicts 4 Jaguar seated before a temple (Fig. 40). The temple sits upon the fragmentary body of a serpent representing Coixtlahuaca. Above the temple is a cattail plant. Again, this configuration fits the Tulancingo-Coixtlahuaca identification (See Smith 1973a: 255).

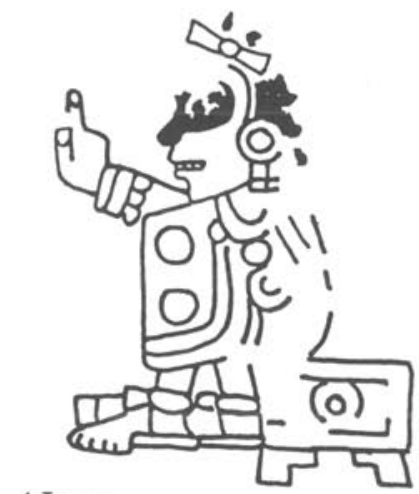

4 Jaguar

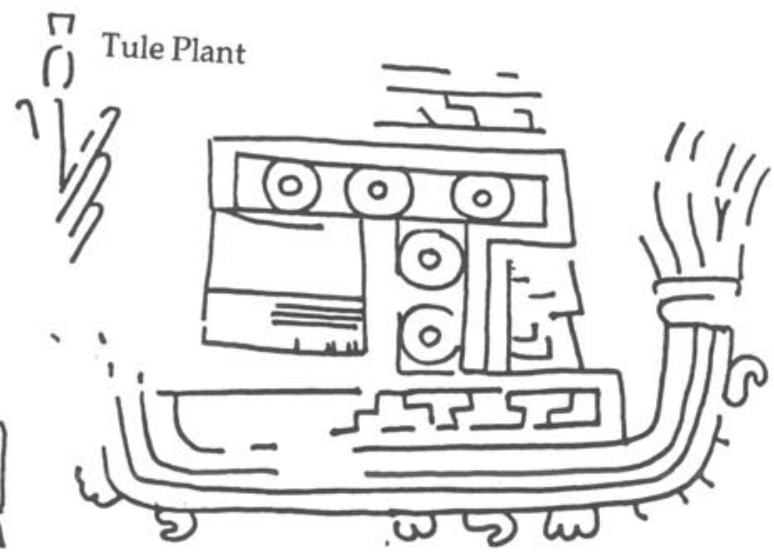

Serpent Place

Figure 40: 4 Jaguar seated before a compound place sign which includes the serpent qualifier for Coixtlahuaca and the cattail plant standing for San Miguel Tulancingo (Becker I 14).

Other evidence for associating Lord 4 Jaguar with the Coixtlahuaca Valley and therefore San Miguel Tulancingo includes a possible figurative appearance in the Lienzo de Tlapiltepec (Fig. 41). Tlapiltepec A 15 (Caso 1961b: Lam.II) depicts the establishment of the first royal house of Coixtlahuaca after the emergence of the ancestors from the caves of Chicomoztoc. Two place signs for Monte Verde and Cuauhtinchan (Temple of the Eagle) are portrayed to signify that the origins of Coixtlahuaca's dynasties were constructed through an alliance between those royal houses (See also Mapa de Cuahutinchan 2 in Reyes 1977: 60) The lienzo Seler II (Konig 1984) portrays the same couples placed together with the more standard Serpent Place sign for Coixtlahuaca.

To the right of the depiction of the first dynasty of Coixtlahuaca stands Lord 4 Jaguar. $\mathrm{He}$ is dressed in many ways, like his cognate appearances in the Mixtec codices, including the top-knot, or temilotl, Toltec hair style. He brandishes the distinctively Toltec macuahuitl, and carries an Aztec style shield. The chevron path and numerous conquest dates indicate that, in conjunction with the Coixtlahuaca dynasty's founding, Lord 4 Jaguar had apparently spearheaded a violent intrusion into the Coixtlahuaca Valley around 1087 A.D. (Troike and Rabin, personal communication); just a few years before his encounter with 8 Deer. Such attacks by the Tolteca-Chichimeca through the Tehuacan Valley (Coxcatlan) and on to Monte Verde are also portrayed in the Mapa de Cuauhtinchan 1. It is also possible however that this is the 
same 4 Jaguar who appears several generations later in the Coixtlahuaca genealogy itself. If this is so, it would appear that the Lienzo de Tlapiltepec 4 Jaguar lived several generations after 8 Deer.

Figure 41: 4 Jaguar (Lienzo de Tlapiltepec).

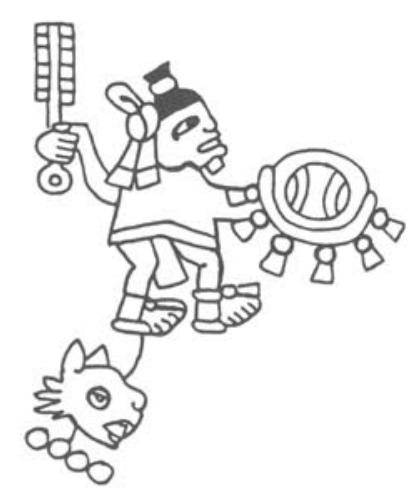

\section{COIXTLAHUACA AND THE TOLTECA-CHICHIMECA}

Coixtlahuaca was the capital of a powerful alliance of city-states that dominated the northern Mixteca Alta from the Tamazulapa Valley to the Tehuacan Valley in Puebla. The region is known for its tremendous linguistic diversity with populations speaking Mazatec, Cuicatec, Mixtec, Chocho, Popolocan, and Nahuatl. Although virtually unknown archaeologically (See Bernal 1948), an important corpus of Colonial lienzos and maps have been attributed to the area (Caso 1961b, Parmenter 1982, Topsey 1985). The maps possess unusual pictorial arrangements.

For example, the Lienzo de Tlapiltepec is divided into two major sections that duplicate much of the same subject matter. The left side depicts the genealogies of two ruling dynasties in a Mixtec style while the right side is a reality-based map showing the distribution of principal communities or teccalli in conjunction with a legendary migration story more closely related to the Mapas de Cuauhtinchan (Bittmann Simons 1968, Jansen 1989). In short the lienzo represents a fusion of two distinct narrative formats that were associated with two different forms of social organization: Mixtec and Tolteca-Chichimeca.

According to various Aztec accounts, Coixtlahuaca was attacked in 1458 by the Empire of the Triple Alliance (see Hassig 1988 for discussion). The Mixtec ruler of that place, Atonal, had executed a number of Mexica merchants thereby incurring the wrath of Motecuhzoma I of Tenochtitlan (Torquemada 1943: 159-160). Following a desperate siege, Coixtlahuaca fell and Atonal was garroted despite of attempts on the part of Huexotzinco and Tlaxacala to aid the beleaguered city-state with whom they were "confederated."

According to the Anales de Cuauhtitlan (Velázquez 1945: 52), Atonal claimed to be 
descended, not from the Mixtec ancestors born from the sacred trees at Apoala, but rather from the "Toltecs" who were born from Chicomoztoc. The origin of this Toltec descent group was traced to an earlier Atonal cited in the Anales (Velázquez 1945: 15) as having joined the migration of the Chichimec from Tula, Hidalgo through Cholula, the Tehuacan Valley, and finally into the Mixteca Alta (See Map 2).

The Historia Tolteca-Chichimeca and the Relación de Coxcatlan (Kirchhoff et al 1976: 135-136, Acuña 1985b: 94) state that this group of Tolteca Chichimeca claimed to be the followers of Xelhua, the first-born son of Camaxtli-Mixcoatl and Ilanque. Codex Ríos records a myth in which Xelhua was also thought to have been a giant during the 4 Jaguar epoch. At that time he survived Tetzcatlipoca's destruction of the earth and built the great pyramid of Cholula.

The origins of the Tolteca-Chichimeca invasions have been reviewed by numerous scholars. The legendary intrusion of the culture hero Camaxtli-Mixcoatl into the Valley of Mexico at the head of militant tribes from the north has been examined by Wigberto Jiménez Moreno (Fig. 42a). He placed the event at the beginning of the tenth century A.D. (Jiménez Moreno 1954-55). Paul Kirchhoff proposed an alternative chronology suggesting that Camaxtli-Mixcoatl lived nearly 200 years later, at a time when 8 Deer would have been active in the Mixteca (See Davies 1977 for discussion). Regardless of the precise dates however, many historical sources indicate that, after Camaxtli-Mixcoatl's death, his son Topiltzin Quetzalcoatl moved the capital of the Tolteca-Chichimeca to Tula, Hidalgo.

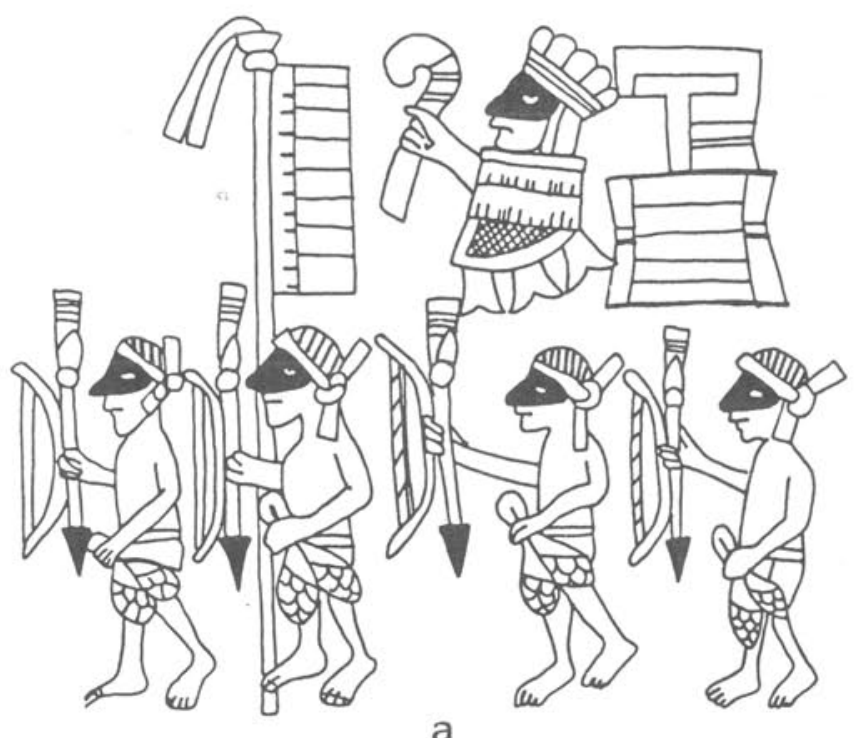

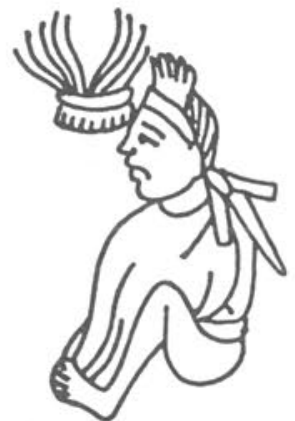

b

Figure 42: (a) The sacred bundle of Camaxtli-Mixcoatl attended by four priests in Sahagún's Primeros Memoriales. (b) Camaxtli-Mixcoatl's son Xelhua in the Historia ToltecaChichimeca (Folio 3r). 
The kingdom thrived until disagreements rose between various political factions, causing the collapse of the city and a fissioning of the population. According to the Historia Tolteca-Chichimeca (Kirchhoff et al 1976: 132-136), Xelhua was one of the first to leave, taking his people (the Nonoualca) around Lake Texcoco to Cholula where they stayed a short time before migrating south, eventually founding the kingdoms of Tehuacan, Coxcatlan, and Teotitlan del Valle. By other accounts, Quetzalcoatl himself led his followers to Coxcatlan.

Although the Historia Tolteca-Chichimeca (Kirchhoff et al. 1976: 136) says that Xelhua died at the beginning of the journey, the Relacion de Coxcatlan (Acuña 1985b: 95) states that he later became Coxcatlan's "governor" (Fig. 42b). The Mapas de Cuahtinchan (Bittmann Simons 1968, Reyes 1977, Yoneda 1981) detail the migrations of the ToltecaChichimeca into southern Puebla and Oaxaca. Map 1 portrays an assembly of over 35 lords at Cuauhtinchan, a powerful city-state lying south of Cholula. Four priestly officials appear wearing not only the deer-skin cloaks of the Chichimec but also the distinctive black face mask of Camaxtli-Mixcoatl (Fig. 43). From Cuauhtinchan, footprints indicate the route taken to Coxcatlan, symbolized by a hill qualified by a shell jewelry collar. San Miguel Tulancingo may be represented by a place sign above it, a hill with cattail plants. Monte Verde is depicted as well (Caso 1961b: 252).

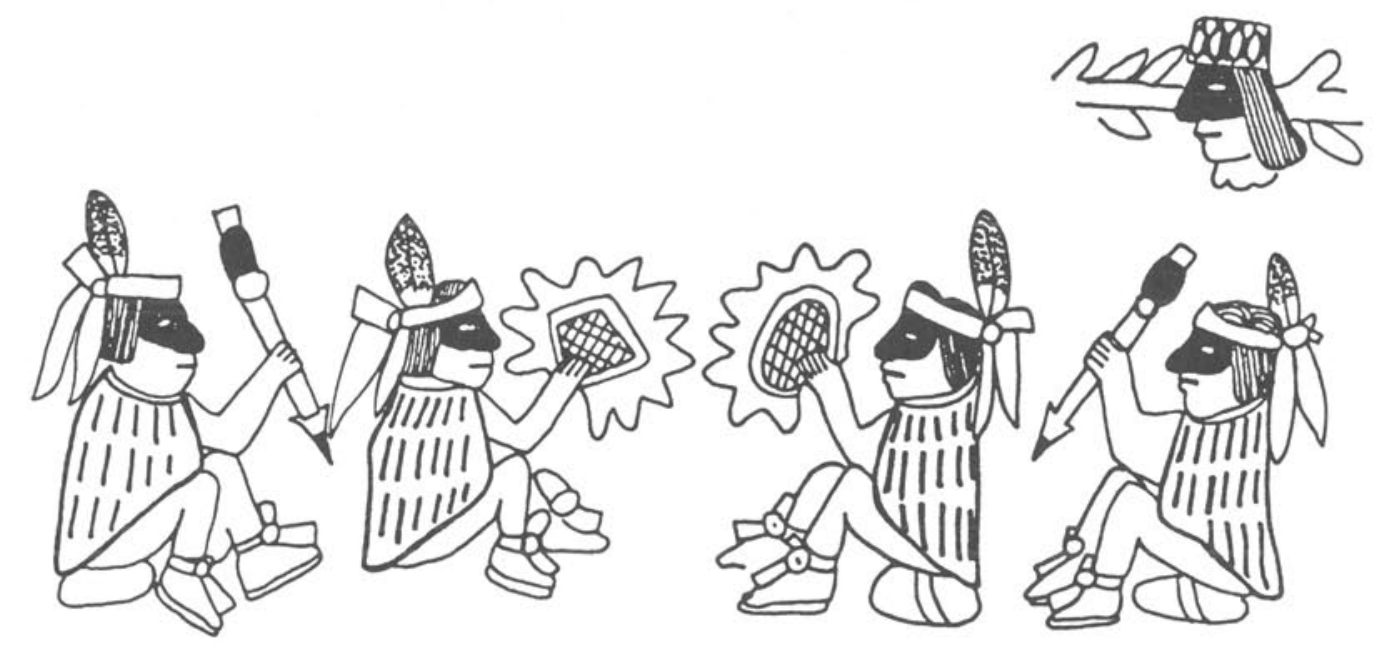

Figure 43: The four Tolteca-Chichimeca priests of Camaxtli-Mixcoatl in Mapa de Cuauhtinchan 1.

Cuauhtinchan Map 2, on the other hand, indicates the route taken directly to Coixtlahuaca, Place-Plain of the Serpent (Reyes 1977: 60). The place sign is depicted as a carpet of serpents upon which are seated two couples, one of whom is Atonal, the progenitor mentioned in the Anales de Cuauhtitlan (Reyes 1977: 60). The pairs also represent the founders of a system of dual rulership at Coixtlahauaca portrayed on the Lienzo de 
Tlapiltepec and related documents (Seler II for instance, Koenig 1984). Standing next to the Coixtlahuaca place sign is, coincidently, a priest wearing the Camaxtli-Mixcoatl black facial paint. He is not specifically identified as 4 Jaguar however.

The question then is how "true" are the Tolteca-Chichimeca migration stories as history? By the late Postclassic, the fall of Tula, Hidalgo had become a myth of epic proportions, complicated by numerous regional accounts that continue to defy any easy synthesis (See Davies 1977). Likewise, the Historia Tolteca-Chichimeca and the Mapas de Cuauhtinchan, are highly unusual portrayals of people, places, and things with regard to what we know of the cultural reality of Early Postclassic Mesoamerica. For example, the Historia Tolteca-Chichimeca depicts men dressed in deer-skin cloaks with bows and arrows walking through the Valley of Mexico as though on a seasonal hunting trip in the desert, hardly an historical reality given the fact that the landscape over which they traveled was settled with thousands of people living in cities, surrounded by thousands of square miles of cultivated land.

The Mapas de Cuauhtinchan extend the metaphor by intermingling scenes of deer hunting with the conquest and defeat of the rulers of Central Mexican city-states. Durán (1971: 140-153) describes festivals in honor of Camaxtli-Mixcoatl as including not only mock-combats but also ritual deer hunts. Sahagún (1951 Book 2: 25-26) said that the victims of sacrifices dedicated to Camaxtli-Mixcoatl were carried to an altar and executed in the fashion of deer captured in a hunt. A Nahuatl language term for a deer trap or snare was metaphorically related as "the road to Tollan" (Alarcon 1984: 103).

Consequently, the migration stories of the Tolteca-Chichimeca probably reflect a more traditional system of cognitive mapping in which legends associated with particular geographical features were recounted by tribal chiefs in the course of seasonal hunting migrations. In the interest of emphasizing an "outsider's" divine right to rule, the Chichimec legends thereby became the legitimate means of conceptualizing a political landscape, even though the reality of the people employing the stories had little to do with the hunting strategies to which they were originally adapted. They were however, ideally suited for lords who needed to emphasize a common "barbarian" origin to confederations of factionalized city-states and the divine rights granted to their teccalli. The Mapas de Cuauhtinchan therefore appear to convey this charter as a kind of New World Aeneid.

The abandonment of the Tula region by the middle of the 12th-century has been confirmed archaeologically (See Sanders et al 1979, Matos 1974, Cobean and Mastache 1989, Matos 1974). Compared with an examination of settlement patterns for the Tehuacan Valley (Macneish et al 1972) the data suggest more importantly, that not only did a large ToltecaChichimeca population reputedly led by Xelhua and Atonal leave Tula, Hidalgo, but that they in fact "arrived" at Tehuacan, Coxcatlan, Teotitlan, and Coixtlahuaca shortly afterwards (See Maps 3 and 4).

Map 3 shows the distribution of sites occupied between A.D. 700 and 1150. At that time the Tehuacan valley was dominated by a large fortified city-ceremonial center, $\operatorname{Tr} 319$, with 
two main ritual precincts, more than 150 range mounds, and a large ballcourt. It was located on a defensible promontory above the modern Popolocan community of San Gabriel Chilac. To the south were located a number of lesser ranking tributary communities (Macneish et al 1972: 449, 460).

Map 4 shows the distribution of sites in the Tehuacan Valley after A.D. 1150. The period was characterized by a sudden explosion of population and the emergence of three new city-states, Tehuacan, Coxcatlan, and Teotitlan on the eastern side of the Rio Salada. By this time the population of the promontory at $\operatorname{Tr} 319$ had moved off the mountain to found Chilac on the western side of the river. Although population increases were characteristic of many Postclassic communities in Mesoamerica, in this case there is a significant difference. Tehuacan, Coxcatlan, and Teotitlan were established by intrusive Nahuatl-speaking peoples while the surrounding region remained Popolocan and Mazatec (see Gerhard 1972: 260-264, 305-309).

Both ethnohistorical and archaeological data therefore indicate that following the collapse of Tula, Hidalgo between A.D. 1100 and 1200, a significant population of ToltecaChichimeca migrated into southern Puebla and northern Oaxaca, where they founded a number of powerful city-states. According to Muñoz-Camargo (1986: 114), these communities once claimed to have been part of a confederation of kingdoms that included Tlaxacala, Huexotzinco, Cholula, Tecamachalco, Cuauhtinchan, Tepeyacac, Tehuacan, Coxcatlan, Teotitlan, and the lands of the Chochos, whose capital was Coixtlahuaca. The ruling ToltecaChichimeca nobility confederated into these alliance corridors claimed to have been descended from the god Camaxtli-Mixcoatl, an heroic manifestation of Tetzcatlipoca. As we have seen, Lord 4 Jaguar and his assistants are distinguished iconographically by the wearing of costume and regalia specifically associated with both of these deities.

The 8 Deer and 4 Wind encounters with 4 Jaguar resulted in the awarding of a distinctive ornament of facial jewelry that was ritually associated with titles to ToltecaChichimeca royal domains as tetecuhtin and not to Mixtec kingdoms as yya. This adoption of foreign lineage titles and even marital alliances between two such distinct social groups as the Mixtec and Tolteca-Chichimeca suggests an analogy to studies by E.R. Leach (1965). Leach analyzed patterns of ritual exchange based on the sharing of lineage titles between the Shan and Kachin of highland Burma. It appears that any individual can be thought of as holding a status position in either social system at one and the same time, even though the Shan and Kachin are linguistically and culturally so distinct that they had even been treated in the past as separate races (Leach 1965: 8).

While the Shan are Buddhists organized into centralized valley communities resembling feudal states with a defined class structure, the Kachin are broken up into separate mountain-dwelling clans with a unique clan-based religion. Actually, Leach found that there is a problem not only in distinguishing Kachins from Shans, but also Kachins from Kachins. Though the Kachins describe their true system, called gumlao, as acephalous and egalitarian, in fact dominant leaders of particular clans have been acquiring royal titles and lineage ties 


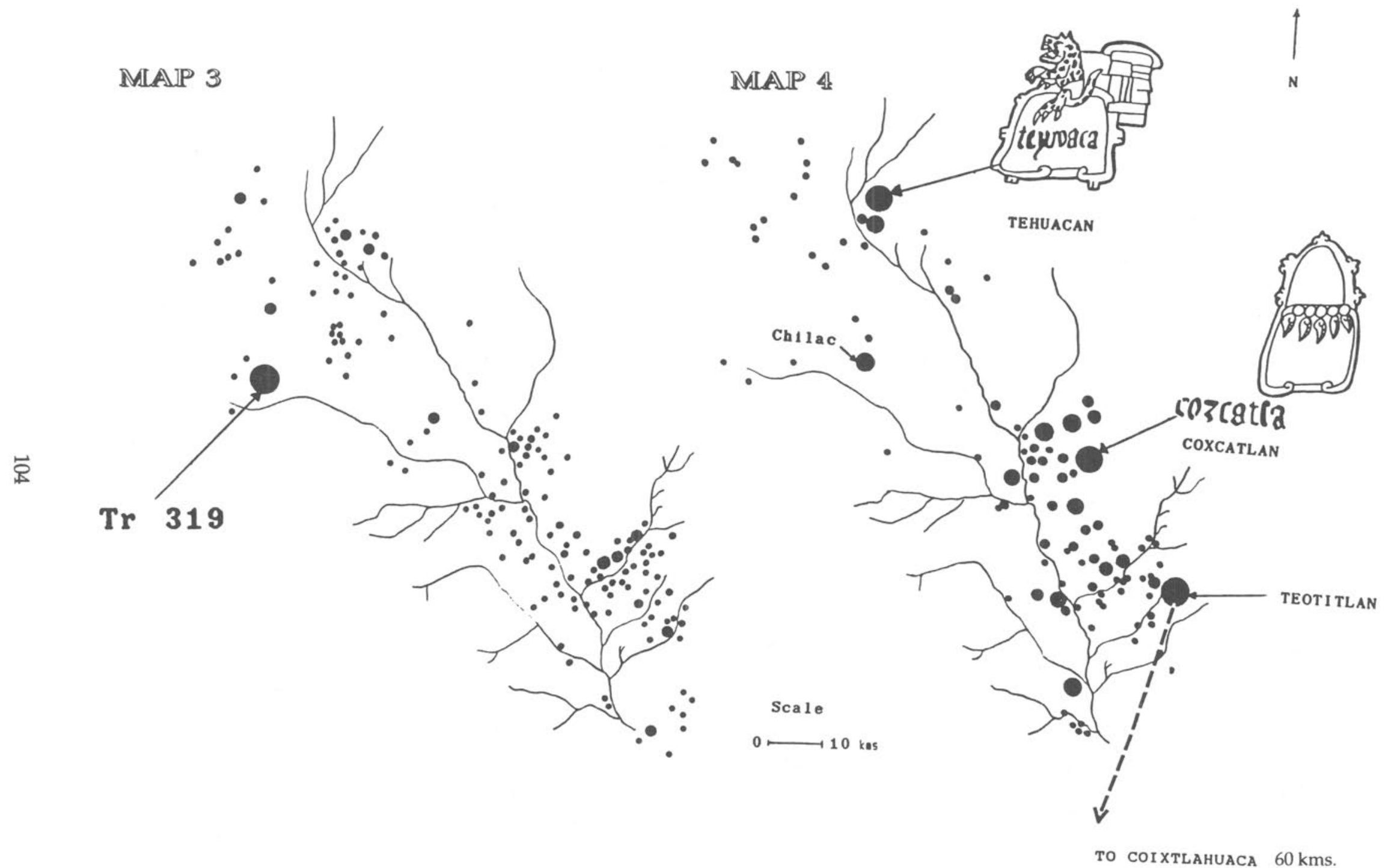

MAP 3: Early Venta Salada (A.D. 700-1150) occupation of the Tehuacan Valley (adapted from MacNeish et al. 1972). MAP 4: Late Venta Salada (A.D. 1150-1521) occupation of the Tehuacan Valley. place signs are from the Lienzo de Ihuitlan, a genealogy from the Coixtlahuaca Valley (adapted from MacNeish et al 1972). 
with the Shan dynasties in an effort to reorganize their clans into feudal states by coercion. This system, known as gumsa, has all the characteristics of a lineage-based system with ranked elites, including some aspects of divine royal authority attributed to the Kachin leader. The difference is that, while the Shan tend to maintain centralized states in the river valleys, the gumsa Kachin still remain factionalized and rooted to clan affiliations with traditional territorial boundaries in the mountains.

Shan titles of legitimacy are negotiated and then symbolically transferred through the exchange of each group's ancestor names (Leach 1965:2). The Shan often initiate negotiations in return for safe mountain passages, new modes of economic exchange, advantageous marital alliances, and a variety of other awards. The Kachin affect the politico-symbolic authority of a Shan lineage head. This becomes a source of power outside the traditional gumlao, but not entirely in conflict with it. Leach concluded therefore that the affectation of a foreign title, though not necessarily rooted in a true kin-based relationship, can thus become an acceptable means by which the incongruity between status and power is symbolically resolved. Many times the exchange of titles is prerequisite to marriages which further bind Shan and Kachin alliance partners. The conditions under which the Shan and Kachin negotiate these alliances have further parallels with the interactions between 4 Jaguar and 8 Deer as well.

Shortly after 8 Deer's success in gaining control of Tilantongo, Bodley $12 \mathrm{~V}$ depicts 4 Jaguar's priests carrying two of 8 Deer's children on their backs to Tulancingo, where they marry as members of the Tulancingo royal house. Smith (1973a: 73) outlined an entire genealogy illustrating the fusion of the royal houses of Tilantongo and Tulancingo after 8 Deer's marriage to Yanhuitlan's Lady 11 Serpent whose grandparents were lords of Tulancingo.

Leach's observations of the exchange of titles in return for access to markets and longdistance exchange is also significant with regard to a discussion in Chapter 1. The ToltecaChichimeca horizon is identified by archaeologists working in the Valley of Mexico, Tlaxcala, and Puebla by the appearance of a distinctive red on cream ware called Coyotlatelco (Noguera 1950). The similarity in the appearance of various Coyotlatelco sub-types, including Yanhuitlan Red-on-Cream points to corridors of social and economic interchange between various early Postclassic city-states from Tula to the Mixteca-Alta.

It is surely no accident of artistic expression, therefore, that 4 Jaguar's priest-envoys are so often shown carrying the staff and fan of long-distance traders. Similarly, Bruce Byland's (n.d. 366) discovery of what was probably a major exchange point in green obsidian brought from Pachuca, Hidalgo, lies, coincidently enough, directly on the border between 4 Jaguar's domain of San Miguel Tulancingo and Tejupan. Although red-on-cream decorated ware has been identified throughout the Tehuacan Valley (MacNeish 1970: 217-220), Coixtlahuaca (Bernal 1948), the Tamazulapa Valley (Byland n.d.), and the Valley of Nochixtlan (Spores 1972); its most intensive, continuous distribution terminates at the southern end of the Valley of Nochixtlan (Pohl and Byland 1990).

The distribution of ceramic types related to Coyotlatelco suggests that following the abandonment of Valley of Oaxaca dominated Classic Period Mixtec centers by A.D. 1000, the 
emergence of new settlement systems was caused by a shift in political influence away from the Zapotecs, and towards Early Postclassic, Pueblan city states to the north. The interactions between 4 Jaguar, 8 Deer, and 4 Wind are therefore manifestations in native historical reckoning of a dynamic period of widespread social upheaval that occurred throughout Puebla and Oaxaca (See Byland and Pohl in press).

\section{LORD 4 JAGUAR AND THE ORACULAR PRIESTS OF CAMAXTLI-MIXCOATL IN COLONIAL TIMES}

Although Oaxacan ethnohistorical sources such as Burgoa's Geográfica Descripción describe the oracular shrines at Mitla, Achiutla, and Chalcatongo in some detail, virtually nothing is described of the Coixtlahuaca area. Tlaxcalan and Pueblan Colonial sources on the other hand, relate the existence of itinerant merchant priests who operated between what would have been the major city-states of the Tolteca-Chichimeca confederations in earlier times. These priests even claimed to be "man-gods" (Gruzinsky 1989), either reincarnations of Camaxtli-Mixcoatl or that deity's personal agents to mankind as itinerant oracles, precisely the behavior with which 4 Jaguar is so clearly associated.

The most famous of the Pueblan merchant-priests was named Martín Ocelotl (Klor de Alva 1980, Gruzinsky 1989: 39-44). According to testimony given at his 1536 idolatry trial (Procesos de Indios Idolatras y Hechiceros 1912), Martin Ocelotl (ie., Martín "Jaguar") was accused of declaring that he was a living god, a reincarnation of Tetzcatlipoca, and the messenger of Camaxtli-Mixcoatl. This was not the only matter that sparked the ire of the Spaniards, however.

Martín Ocelotl was the son of a Pre-Conquest priest-merchant. His mother was said to have been a powerful sorceress. As a novice he was a member of a holy delegation to Motecuhzoma II from Chinantla, Puebla, that foretold the destruction of the Empire of the Triple Alliance by the Spaniards. As the bearer of bad tidings, he was put to death but later miraculously resurrected himself. After the Conquest, he became a successful merchant and itinerant diviner, amassing a fortune in land and valuables detailed in an Inqusitional account of his property (Procesos de Indios Idolatras y Hechiceros 1912: 37-39). The real problem was that Martín Ocelotl was spear-heading an insurrectionist movement, even inciting native caciques to revolt against Spanish authority.

Ocelotl built a power base upon economic enterprise. He ventured into raising exotic plants like maguey, produce for upper-caste consumption even within the Spanish Colonial economy. He organized trading ventures with towns throughout Puebla, Tlaxcala, Mexico, and Morelos. In Tepeyacac, for example, he had cotton mantles woven for transport and exchange throughout Central Mexico. He bartered for other commodities with deer hides that he procured in the Sierra de Puebla. Martín Ocelotl also amassed a considerable fortune in gold 
and silver jewels (Barlow 1954). His dealings with the caciques of Cuauhtinchan, Tepeyacac, Tecamachalco, the Soconusco, and even Mexico City, direct inheritors of the Pre-Conquest titles of tetecuhtin, brought him gifts of lands that he then used to expand his plantation enterprises. He further bound noblemen to him through money-lending.

Many of the gifts were payments for his success as a native diviner and physician. For example, political connections with the capital administration in Mexico City resulted from his medical supervision of Don Pablo, the native Governor (Procesos de Indios idolatras y Hechiceros 1912: 26). By 1536, Martin Ocelotl had clearly become a key advisor and mediator between a number of powerful noblemen in central Mexico. It was at that time that he reputedly began to prognosticate the end of Spanish rule and to promote himself as the catalyst of an insurrection by invoking divine oracular authority.

According to a number of testimonies, Ocelotl organized a native religious festival dedicated to Camaxtli-Mixcoatl, to be held in an underground oracular shrine (See Klor de Alva 1981: 135 for summary). He sent a call to all of the caciques with whom he had had dealings in the past, asking them to come to him. In the course of the ceremony, Ocelotl then told his followers of a visitation by two demons, or tzitzimitl, who had descended from heaven to declare that there would be a great famine. This was taken by the Spaniards, however, as nothing less than a prediction of the end of their rule.

Indeed, an oracular priest who predicted famine to a native elite was sending a clear message that the ability of an administration to provide the redistributional services expected of centralized government was about to become severely overburdened. This was a situation that would, of course, have stimulated contemplation of secession or revolt in the factional agrarian societies of Precolumbian America. In 1537, Martín Ocelotl was convicted by the Inquisition and sentenced to life imprisonment in Spain. He apparently died in custody, either before leaving Mexico, or in a shipwreck.

Shortly after Martin Ocelotl's trial, a new reincarnation of Tetzcatlipoca/CamaxtliMixcoatl appeared named Andrés Mixcoatl (Gruzinsky 1989: 31-62, Procesos de Indios Idolatras y Hechiceros 1912 53-79). Mixcoatl claimed to be Martín Ocelotl's brother and the inheritor of his position and authority. Although limited in his geographical range to evade persecution, Andrés Mixcoatl traveled from community to community, like his predecessor, predicting the end of Spanish rule. He emphasized his divinity and declared that, as the reincarnated patron deity, he should receive homage from the native nobility in pagan festivals. He would also divine for the lords with the use of hallucinogenic mushrooms. It was at such times that he would demand tribute in return for working miracles and operating as a "rainmaker." Tribute collection given to him as a god enabled Mixcoatl to enrich himself as Ocelotl had done.

Significantly, such tribute was given in the form of sacrificial offerings that included copper "mushroom" or axe-money (see Monaghan n.d.b.: 26-27 for discussion). Mixcoatl had demanded 3600 ingots that would be transformed into arrow heads with which to kill the 
Spaniards (Procesos de Indios Idolatras y Hechiceros 1912: 58). (26) Nonetheless, like Martín Ocelotl, Andrés Mixcoatl was eventually captured and appeared before an inquisition. He was punished with incarceration, but later absolved by the church.

The activities of Martín Ocelotl, Andrés Mixcoatl, and others who followed them, like the 17th-century Juan Coatl "Cloud Serpent" (see Gruzinsky 1989), are so similar as to suggest that their behavior was rooted in institutionalized forms of oracular divination and mercantilism extending back into the Preconquest era, especially given the fact that the first Camaxtli-Mixcoatl-Tetzcatlipoca deity impersonator, Martîn Ocelotl, was emulating the traditions of his father and mother. Comparing the titles, symbolic attributes, and activities of Lord 4 Jaguar (see Chart 4) in the Mixtec codices, to those of Martín Ocelotl or Andrés Mixcoatl, it is clear that they shared the same kind of religious and political authority. They were also affiliated with the same socio-political group, the Tolteca-Chichimeca. Martín Ocelotl even bore the same calendrical name, "Jaguar," as 4 Jaguar; while Andres Mixcoatl bore the name of the deity that all three were invoking, Camaxtli-Mixcoatl. In addition to proclaiming themselves "man-gods," two of them at least were credited with unusually long life spans. By some accounts, Ocelotl was said to be more than 100 years old.

Finally, 4 Jaguar, Martín Ocelotl, and Andrés Mixcoatl were obviously employing the same strategies, using their skills as long-distance merchants to support their activities as itinerant oracles and political power brokers. This was an aggressive strategy developed by the Tolteca-Chichimeca, in which a lord did not have to journey to a cult center like Cholula; rather, the cult came to the lord. Although we have no direct evidence of either Martín Ocelotl's or Andrés Mixcoatl's ever having had dealings with Coixtlahuaca specifically a number of the communities with whom they were trading in the Sierra de Puebla were those that had once controlled the green obsidian sources of Pachuca, the material which shows up in such large quantities in the processing center or market lying adjacent to San Miguel Tulancingo (Byland n.d. 363-368). Colonial evidence for such long distance exchanges is certainly evident in an account of Martîn Ocelotl's money and jewels (Barlow 1954). Surviving documents include references to gold and silver objects shaped like eagles, and sacks of cacao that were sent to the diviner by the lord of the Soconusco, Chiapas. 


\section{DISCUSSION, SUMMARY AND CONCLUSIONS}

By A.D. 1000, the Mixtec had become organized into multiple kingdoms dominated by the yya tnuhu, an aristocratic class of lords who embodied divine descent from a plurality of lineage ancestors miraculously born from caves, trees, rivers, the sky, or other significant geographical features found throughout highland Oaxaca. The yya tnuhu justified claims to their domains through creation stories, kinship, and accounts of descent found in the Mixtec codices.

The codices, then, are "histories" but unique histories in that they reflect how the Mixtec themselves viewed their political universe without the bias of Western European interpretation. The very fact that they are historical tells us a good deal in itself. There is often a tendency among scholars to think that manuscripts of the Mixtec corpus are in some way "truer" to a Mixteca-Puebla figurative system, simply because the scenes are arranged in a sequential order, illustrate a story, and are hence deemed legible.

Actually, the highest proportion of surviving codices known for the ancient cultures of Mesoamerica deal with religious or ritual ideology and not with "history" in the Western sense. It is only when the Spanish administration began to require historical records that manuscripts such as Codices Xolotl, Mendoza, Telleriano-Remensis, and Ríos/Vaticanus A, were created in greater quantities to portray the indigenous past. It is the Mixtec pictorial format that is a variant and not the norm for ancient Mexican codices.

Further evidence lies in a comparison between the Pueblan and Mixtec documentary sources (Pohl, in press). The tetecuhtin of Pueblan kingdoms produced maps and migration histories like the Mapas de Cuauhtinchan and the Historia Tolteca Chichimeca, when called upon by Spanish administrations to document territorial claims. We do not know what system they used before the Conquest, as there are no surviving antecedents. By comparison, the Mixtec drew maps for the Spaniards like the Mapa de Teozacoalco, but they did so only by rearranging the structure of place sign lists found in Precolumbian codices, while continuing to paint off to one side the genealogies associated with territorial units.

From a structural perspective, both the Pueblan and Mixtec pictographic systems are clearly the result of two different conceptions of elite power and territorial control. At the end of the Classic period, the dissolution of authority vested in Teotihuacan, Cholula, and Monte Alban led to large-scale community fissioning and the creation of a highly factionalized political universe extending from the Valley of Mexico to the Valley of Oaxaca. Although dispersed and segmented these kingdoms continued to engage in long-distance trade and eventually formulated powerful alliance corridors. The Mapas de Cuauhtinchan illustrate the creation of these alliances by describing the emergence of the first ancestors from the seven caves of Chicomoztoc, and the legendary odysseys of either the culture hero Camaxtli Mixcoatl himself or his "sons" and priests. 
Emphasis however is placed on the establishment of each teccalli, the landed estate of a Nahuatl tecuhtli, and not on portrayals of genealogical connections or inheritance patterns. This was in keeping with the nature of both Pueblan and Tlaxcalan lordship. The title of tecuhtli was granted upon election by various members of the teccalli and not by strict rules of primogeniture or some other system of family inheritance. Each teccalli therefore evaluated its status according to its placement within a hierarchy of teccalli, a pattern set forth by the first Tolteca-Chichimeca migration heroes.

Muñoz Camargo (1986: 127-131) for example described the foundation of the royal houses of Tlaxcala on the basis of their relationship to Tepeticpac, the first teccalli to be established. Figure 36 shows the founding of Tepeticpac by Lord Mazatl (Camaxtli-Mixcoatl?) on Mapa de Cuauhtinchan 3. The Lienzo de Tepeticpac portrays the relationships that were then established between dependent teccalli either through lineal connections to Lord Mazatl himself or directly to the royal house of Tepeticpac (See also the Matrícula de Huexotzingo).

The Mixtec on the other hand granted the authority to royal estates through a reckoning of divine descent and preferred inheritance patterns, usually primogeniture. Emphasis in the Mixtec codices is on the use of genealogy to relate a developmental sequence of kingdoms that likewise bound themselves together into powerful alliance corridors (Pohl in press). Figure 44, for example, illustrates how the genealogical section of Codex ZoucheNuttall 26-35 can be used to reckon the construction of the alliance corridor that joined Mixtec Tilantongo with Zapotec Zaachila (See Jansen 1982b). It portrays the passage of power from 8 Deer through his direct descendants to the royal lines of Teozacoalco and, later, Zaachila (Pohl, in press).

The Mixtec codex format is uniquely adapted to recounting descent history, in just the same way that the Mapas de Cuauhtinchan became the answer to describing the creation of the first teccalli. Both systems in turn ultimately describe the socio-political relationships which bound their factionalized kingdoms together. Significantly, the lienzos of the Coixtlahuaca group appear to show a fusion of the two systems. The Lienzo de Tlapiltepec (Caso 1961b) depicts a continuous Mixtec-style genealogy of the royal houses of Coixtlahuaca on one side, $A B$ 1-36; on the other side, $C D E F$ 2-24, there is a Cuauhtinchan style map of the migration of certain Coixtlahuaca lords both to and from the Tehuacan Valley and Cuauhtinchan.

Comparable "histories" in other traditional societies led Marshall Sahlins (1983: 517) to point out that Western historians have been arguing for a long time over two polar ideas. Many scholars support the analysis of an elite history, narrated with its partiality to higher politics, while others favor the study of the would-be life of communities. Actually, both positions merely reflect the evolution of thought since the first empirical treatments made by the Classical Greeks. Sahlins proposes, therefore, that many traditional societies did and still do maintain a different kind of historical tradition that might be better described as "heroic history." 


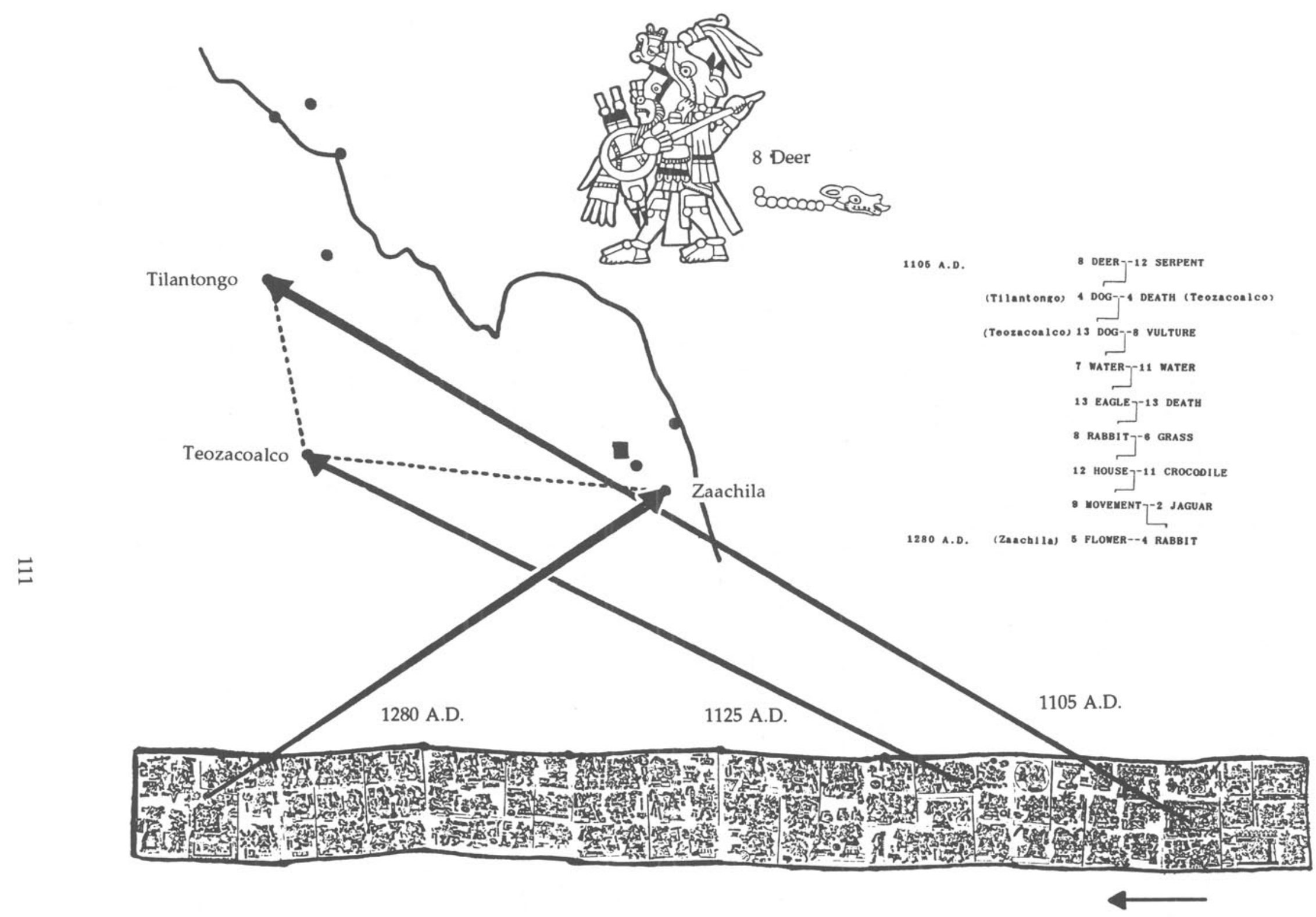

Figure 44: The Codex Zouche-Nuttall obverse outlines the construction of an alliance corridor through the reckoning of genealogical connections between Tilantongo and Zaachila. Following 8 Deer's rise to power in 1105 A.D., he marries Lady 12 Serpent of Red and White Bundle. One son, named Lord 4 Dog, marries Lady 4 Death of Teozacoalco by 1125 A.D. Their descendant, Lady' 4 Rabbit, marries Lord 5 Flower of Zaachila by 1280 A.D. 
In such societies, "heroes" are seen as persons who were considered extraordinary in thesociety during their lifetime, who were honored after death by public worship, and who were usually ascribed some degree of divinity. Heroic history, then, is usually elite genealogical history. It is not evenly distributed in the society, as it is in and of itself a symbol of politico-religious authority reserved for the ruling class (Fig. 45). Sahlins' observations are applicable to the ideology of ancient Mixtec rulership and to the codices themselves. If, as Sahlins suggests, different cultural orders have their own ways of reckoning historical action, consciousness, and determination, it should be possible to identify critical aspects of Mixtec socio-political organization on the basis of what they themselves thought necessary to communicate.

Above and beyond the fact that Pre-Conquest Mixtec lords were obviously so concerned with time-reckoning and genealogical accounts, what is notable is the tremendous number and variety of persons involved with the foundation of Mixtec kingdoms as related in Codex Vindobonensis obverse or the 8 Deer story in Zouche-Nuttall reverse. The Mixtec did not appear to revere any one original ancestor, but rather some kind of hierarchy of divine priests and ancestors, probably headed by the mythical culture hero 9 Wind Ehecatl-Quetzalcoatl. Although it is not clear that he is ever shown marrying or producing heirs, 9 Wind was certainly the focus of an important bundle cult and lineage patron of Tilantongo (Caso 1960:52, Nicholson 1978:81-88). Other personages, such as 8 Wind (Zouche-Nuttall 1-7), who might actively interact with 9 Wind, do marry, however, and begin royal dynasties.

The lack of any single founding ancestor reinforces the perception that the Mixtec maintained a plurality of royal lines, and mention of extensive lists of place signs in Codex Vindobonensis, for example, implies that Mixtec lords were settled into multiple territorial units, an observation reflecting the decentralization of authority so evident in archaeological settlement pattern studies (Spores 1972, Byland and Pohl in press) (Map 5).

Laura Bohannan presented some very good points concerning genealogical history. Groups who order their society on the basis of lineage and kinship value genealogy. However, genealogies in traditional societies are often oral and open to interpretation. The operative logic is that, first, the genealogies validate present relationships; second, these relationships prove the genealogies; and third, the form of the genealogy is modeled on the form of the present relationships (Bohannan 1952: 312-315). Bohannan found that disputes are handled by a council of elders, presumed to be unbiased in their decision making.

As European writing and filing systems began to appear among her study group, the Nigerian Tiv, Bohannan found that the genealogies began to stabilize. By then only men of great influence such as government chiefs and their scribes had the training to document what they alleged to be the correct genealogical record of the society. Eventually, these became "true" records of their lineage history, and other, equally valid versions were negated as "false." This in turn led to a fixing of the traditional territories into the possession of the 

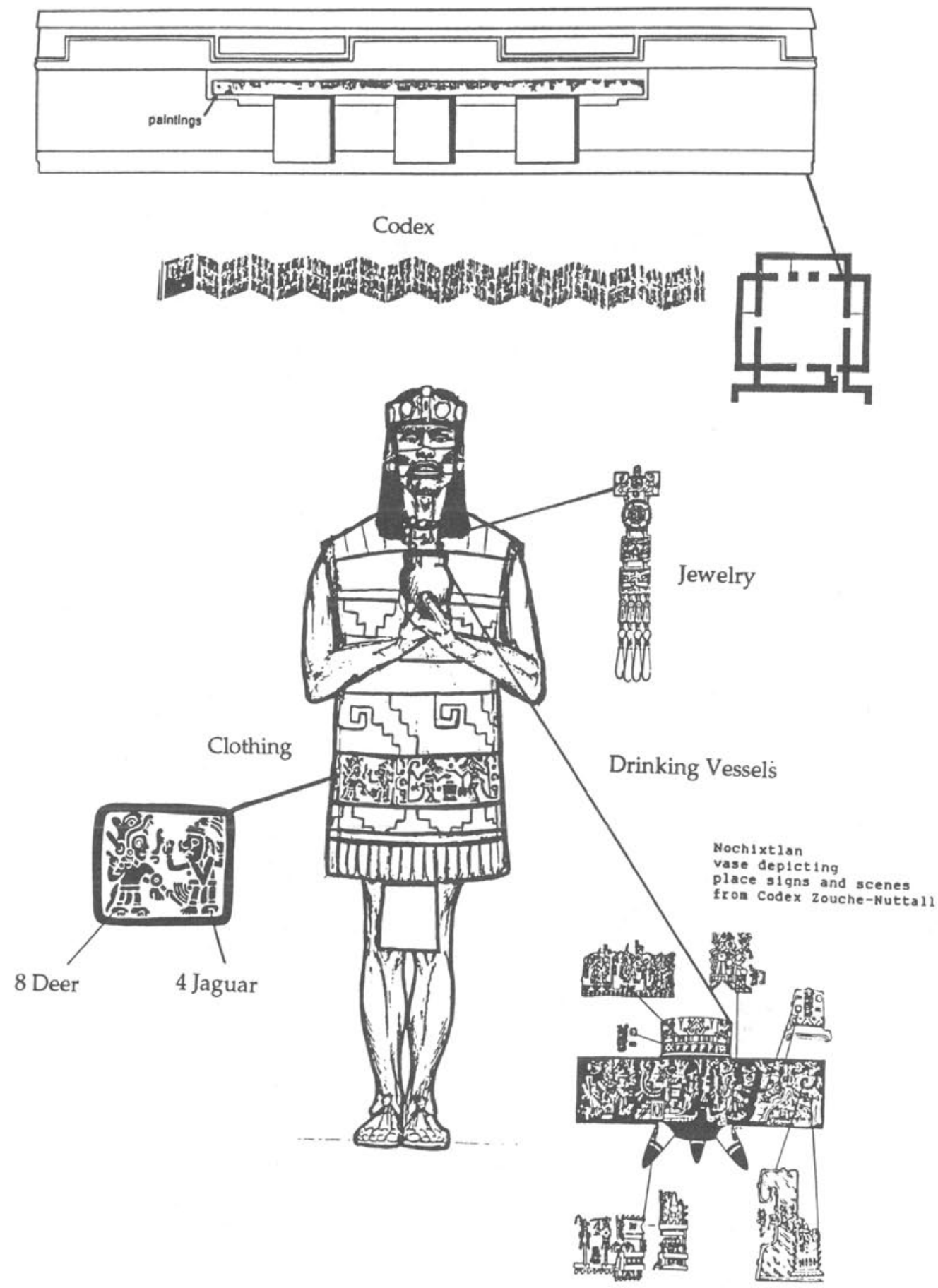

Figure 45: The employment of narrative history painted in the Mixteca-Puebla style was restricted to very specific forms of elite social behavior providing a symbolic context for feasting, gift exchange, and other forms of socialand political intercourse carried out in palace courts. 


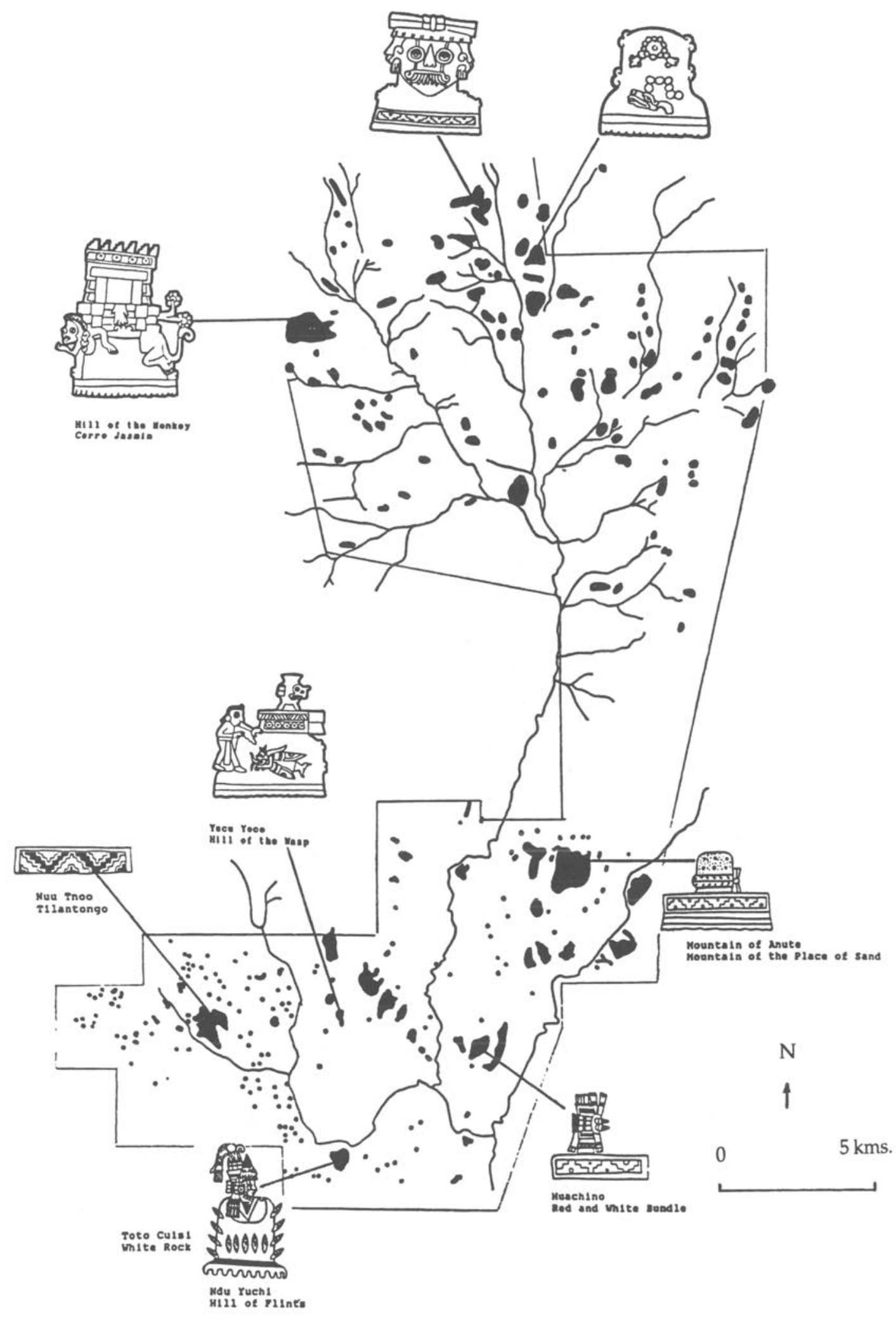

MAP 5: Las Flores (Late Classic A.D. 1000-300) occupation of the Nochixtlan Valley (adapted from Spores 1972, Pohl and Byland 1990). 


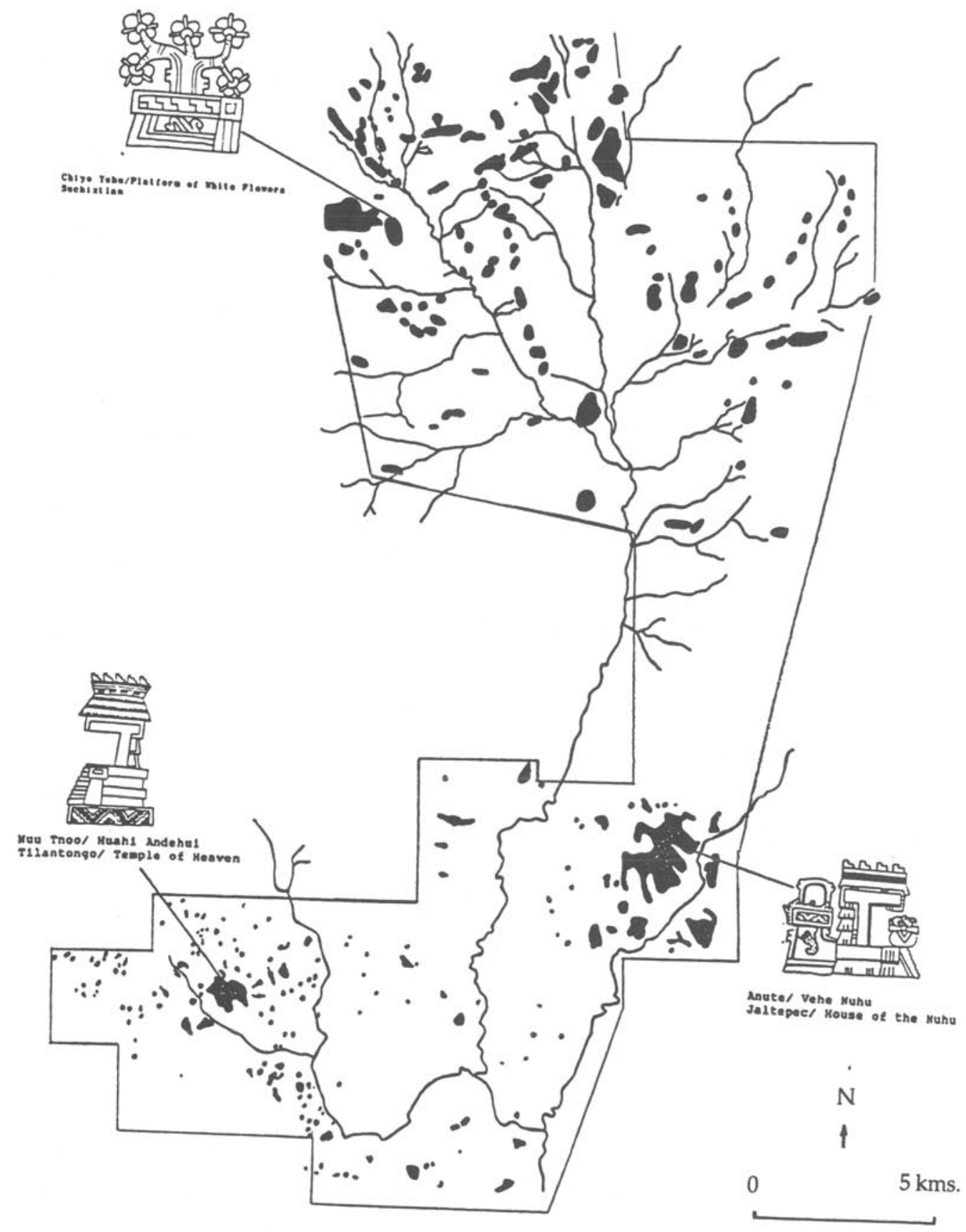

MAP 6: Natividad (Postclassic A.D. 1000-1521) occupation of the Nochixtlan Valley. Comparison with MAP 5 indicates large scale abandonment of major Classic centers by A.D. 1000. Place signs representing these communities are depicted in accounts of the War of Heaven and 8 Deer stories in the Mixtec Codices (adapted from Spores 1972, Pohl and Byland 1990). families of these influential men, and titles to these lands were passed on by hereditary right. 
The authority transmitted by the oral history of the council of elders was thus greatly diminished, and the nature of political power in the society was irrevocably altered.

The result of such processes is that documentary historical reckoning becomes a kind of mirror of historical reality. A good case in point is the archaeological observation that Yucuñudahui (Black Hill of the Rain God) was the most powerful Terminal Classic site in the Nochixtlan Valley by A.D. 900, controlling the most productive lands in the region (Spores 1984: 30-48). Nevertheless, the site receives only secondary mention in the codices. For example, it appears on Vindobonensis 47 at the beginning of the extensive place sign list, where the culture hero 9 Wind Ehecatl-Quetzalcoatl appears to be raising the sky above the site. Subsequently, Yucunudahui has virtually no role in the recounting of genealogical history in the codices from 950 A.D. to the time of the Conquest (Map 5).

The reason for this could be that, by the 16th-century, the paramount authority in the Mixteca Alta had shifted into the royal house of Tilantongo in the southern end of the Nochixtlan Valley. This situation was no doubt the result of Tilantongo's superior ability to broker alliances with its southern neighbors, including a powerful inheritor to Monte Alban's authority in the Valley of Oaxaca, Zaachila. Any memory of Yucuñudahui as a powerful capital, therefore, became secondary to Tilantongo's interest in telling the story of the fissioning of Classic sites and the creation of its own dynastic reckoning from the perspective of the opposite end of the Nochixtlan Valley (Map 6).

In this study it is argued that, despite the obvious bias as history (see Marcus 1992), Mixtec codices present the fundamental symbolism of cultural ideals concerning political action and reaction. By concentrating on the period of the usurper, Lord 8 Deer, it has been possible to study a Mixtec system for the transference of power during a period of instability and, consequently, a time when the mechanisms of government become most visible (Goody 1966: 1012). The fundamental question asked in this study about the 8 Deer story, is how an individual who lacked true legitimacy gains power and operates in a Mixtec factionalized political system, that is what forms of symbolic action could an ambitious Mixtec lord follow?

In an effort to deal with this question, I have isolated four orders of political operatives whose authority was maintained through the specialized manipulation of an elite historical religion. The first was a group of priests, four in particular. They are usually recognizable by their manner of dress which consists of a black-and-white xicolli, black face and body paint, and usually some skeletal attribute. In Zouche-Nuttall 5, the great patriarch 8 Wind is shown emerging from a cleft in the platform of a temple. He is met by four priests. The first priest sprinkles tobacco onto a quail while the last blows a conch shell trumpet. It is significant that this sacred body of four is present at the miraculous birth of the ancestor. It implies that the priests had been created first. In Chapter 2, it was proposed that these priests were the caretakers of royal authority, specifically concerned with the maintenance of the sacred bundle cult so important to succession and rulership, and thus forming part of the check and balance system needed for the stability of government in the face of competing royal kin groups. They even served as stand-ins and stake-holders. 
This role is suggested by the position fulfilled by 8 Deer's father 5 Crocodile, a member of the holy council. Corroborative evidence for the roles of such priests was also found in the case of the cacique-gobernador of Yanhuitlan, Don Domingo de Guzmán and his associate Don Francisco, when the heir to the cacicazgo, Don Gabriel, was judged too young to act on his own behalf. It was Don Domingo who actually managed the estate until the boy was old enough to assume his title while Don Francisco supervised the sacred bundles until their seizure by the Spanish encomendero, Don Francisco de las Casas.

The second office of internal administration examined here was that of the yaha yahui, the Eagle-Fire Serpent diviners. These priests are less visible in the codical records making appearances at the foundation accounts of powerful kingdoms and committing human sacrifices. They were considered to be wizards and credited with the ability to transform themselves and to fly to the heavens or pass through the earth to speak with the ancestors directly. In addition to fulfilling the most sacred roles as sacrificial priests and diviners, the yaha yahui were especially connected to the wealth of the kingdom operating in a fashion not unlike institutionalized mayordomos.

The role of the yaha yahui was further examined with regard to metaphors of sacrifice and economic exchange that continue in traditional Mixtec communities today (Monghan n.d.a., n.d.b.). It seems most likely that the yaha yahui were the supervisors of tribute collection and redistribution in the royal administration. Indeed, Don Juan, the third Yanhuitlan gobernador to be tried by the Spanish Inquisition for idolatry, was accused of taking mushrooms and communing with his ancestors, committing human sacrifices, and inciting the people of Yanhuitlan to worship the god of the merchants.

On the basis of examinations of political behavior in the pictorials, and on an analysis of the roles of the accused in the Yanhuitlan inquisition, it was concluded that the administrations of Postclassic Mixtec kingdoms focused mainly on three groups of people (Fig. 48). The first was the yya or paramount lord, whose position was defined by descent from a deified ancestor. The second was a body of four priests, relatives of the yya, who supervised the realm as judges and whose leader headed the war council. The third were the yaha yahui or sacrificers, whose responsibilities included the maintenance of the royal economy.

Another relationship that was deemed critical not only to lord 8 Deer but also to his rivals, Lady 6 Monkey and her son Lord 4 Wind, involved the Lady 9 Grass. The nature of Mixtec social organization described in this study has been characterized as decentralized and factional (see Dahlgren 1954, Spores 1967, 1972, 1984). It is argued here that, although the system lacked any centralizing power comparable to Monte Alban's role in the Classic period, the ideology of nationalism was transformed into the elite subscription to funerary cults that were supervised by either the oracular huipatoo or "great seer" of Mitla (probably the god 13 Flower) or the goddess 9 Grass of Chalcatongo.

Significantly, it was the royal house of Tilantongo that came to be buried at Chalcatongo and the royal house of Zaachila that was entombed at Mitla. Both of these 
dynasties were considered to be the highest ranked of the Mixtec and Zapotec royal lineages respectively. By A.D. 1280, both kingdoms had formulated marital alliances through Teozacoalco. Other royal Oaxacan kinship groups thereby reckoned their own rank on the basis of their lineal relationship to either one or the other. It is logical that the physical preservation of the bodies of the highest ranked royal lines could then be perceived as a more precise genealogical record than any pictorial account which might be altered by competing lords and their councilor priests. The oracular ability to arbitrate disputes and ultimately settle matters of inheritance obviously stemmed from the control of these more tangible "facts."

One of the most interesting aspects of the Lady 9 Grass is her display of the unique combination of life and death transformation imagery in her costume and in the skull temple over which she presides. The Alvarado dictionary (1962: 188B), for example, lists a term for a tomb as dzocoyeque. The latter part of the term, yeque, means "bone." Dzoco, on the other hand, can refer not only to a cave or rocky crevice where the bones of the dead were placed but also to a woman's "womb," the source of life. An oracular priestess seeking symbolically to support a position that arbitrated the transformation of royal status could not have selected a more potent combination of symbols.

The fourth and final relationship examined, and one that both Lord 8 Deer and Lord 4 Wind engaged in, concerned an alliance with an outside source of authority, the oracular priest Lord 4 Jaguar of Tulancingo. It was proposed that, since 8 Deer lacked the proper genealogical background to take control of Tilantongo, he needed to explore other forms of legitimacy. The Tolteca-Chichimeca yacaxihuitl ceremony was ideally suited, for it was a ritual in which a lord became a tecuhtli or head of a lineage house by election. By undergoing the ceremony with the Tolteca-Chichimeca 4 Jaguar, 8 Deer also gained a valuable military alliance in his effort to eliminate his own Mixtec competitors.

Studies of oracular power in Early Postclassic Mexico hold considerable potential for future analyses of Pre-Aztec Imperial social organization. Although we have accounts of the oracular priests of Cholula and Tehuacan in Puebla (Rojas 1927, Motolonía 1903: 70-71), more detailed descriptions of these ecclesiastical authorities come from Oaxaca, with the oracles of Achiutla, Chalcatongo, and Mitla (Burgoa 1934). Map 7 illustrates a hypothetical reconstruction of the distribution of oracular shrines between Oaxaca and Puebla based upon a number of ethnohistorical sources reviewed in this study. Cult affiliations with patron deities whom we know the priests often impersonated are documented both in this study and in forthcoming works (Rojas 1927, Nicholson 1955, Byland and Pohl in press, Pohl n.d.b.).

The distribution and the specialized nature of the cults located throughout Puebla and Oaxaca indicate that the elite patronage of certain shrines in the Postclassic would have formally resembled the Christian pilgrimage systems that continue to link major portions of 


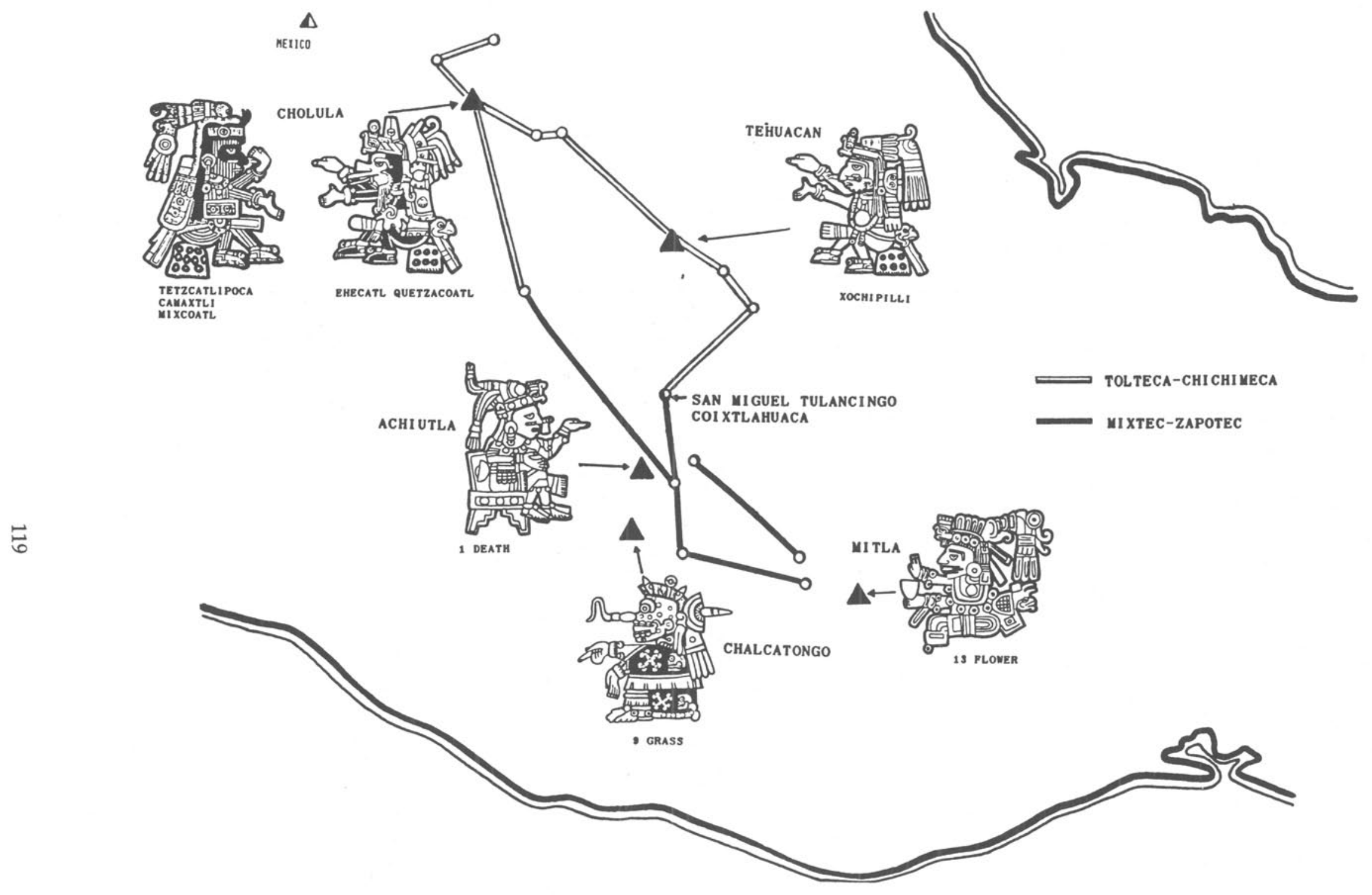

MAP 7: Late Postclassic oracular shrines and associated priests in Puebla and Oaxaca. 
Mexico today, both spiritually and economically. Merecedes Olivera (1970), for example, plotted the distribution of communities who patronize the cult of the Virgin de los Remedios at Cholula. Comparing her map to the community lists in the Historia Tolteca-Chichimeca and the Cuauhtinchan maps, Olivera discovered a striking 1000-year continuity in the extent of Cholula's spiritual authority, ranging as far south as the Mixteca Alta. Likewise, Mitla continues to be a major pilgrimage shrine in Oaxaca, drawing pilgrims from all over the state (Parsons 1936).

The economic power inherent in the enormous, latter-day markets and periodic fairs given at Cholula and Mitla has been a source of considerable anthropological interest (Olivera 1970, Parsons 1936). This fusion of regional economic authority with a cult religious center appears in the Mixtec codices as well. In nearly all encounters with oracular deity impersonators, Mixtec lords are seen either giving or receiving precious objects, usually gold or silver jewels like those found in Oaxacan tombs (Fig 46). Remembering that it was precisely through dealing in these kinds of jewels that Martín Ocelotl (Barlow 1954) operated as a money lender and financed his insurrectionist movement, we may glimpse the foundation of a widespread system of accumulated wealth and power brokering on the part of oracular priests in the Postclassic.

a
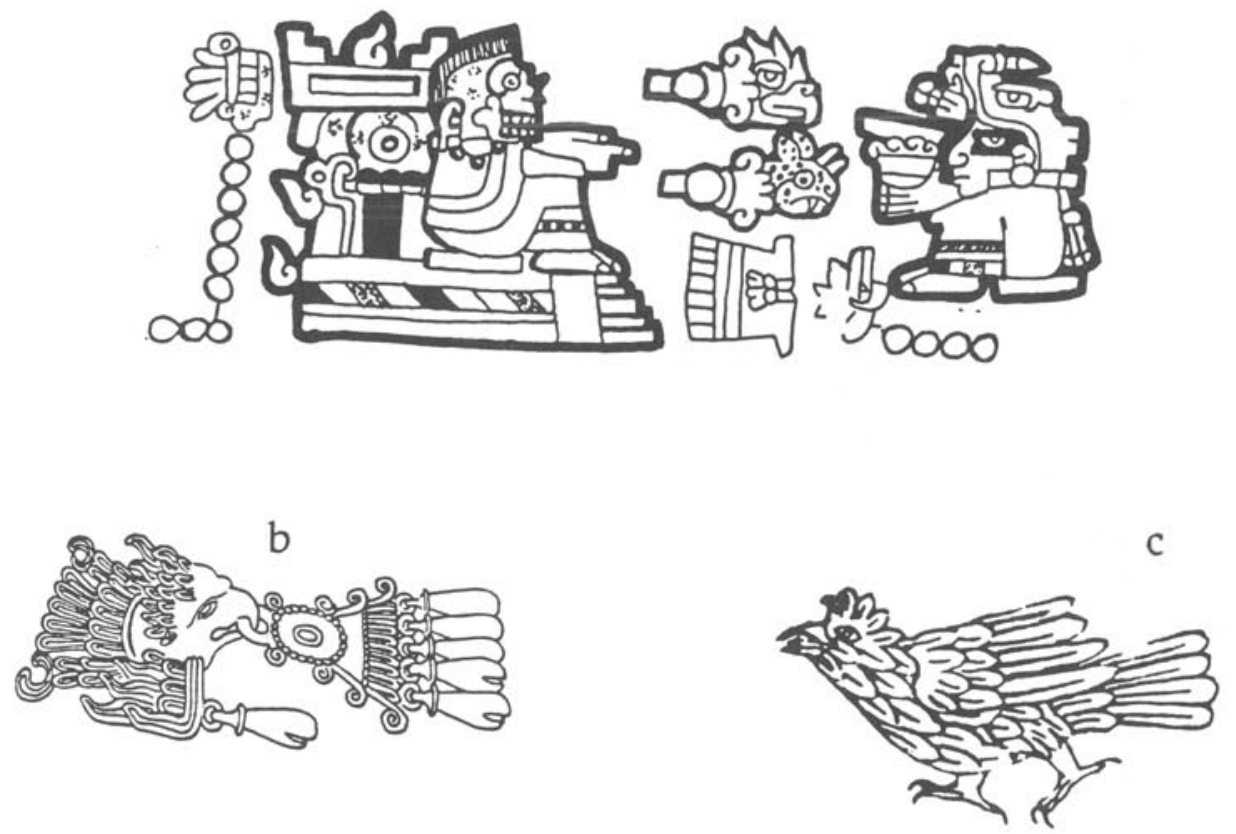

Fig. 46 (a) The oracle Lady 9 Grass awards Lord 4 Wind with two jewels shaped as an eagle and a jaguar. (b) Jewel from Tomb 7, Monte Alban shaped like an eagle. (c) Jewel shaped like an eagle, belonging to Martín Ocelotl's treasure. 
In conclusion, this study by no means fully covers the majority of personages who played roles in ancient Mixtec political affairs. For instance, there is evidence of authority rooted in age-set systems reflected in the portrayal of various snaggle-toothed elders who appear as priests, shamans, or warriors, but who are seldom shown marrying, producing heirs, or ruling estates. There are also a good number of other "deities," like Lady 9 Grass, with whom aspiring lords converse in their efforts to promote their position. The most prominent of these is the solar god oracle 1 Death (Caso 1959). Although he was located at Achiutla and therefore certainly of Mixtec affiliation, he seemed to have had some special influence over Tolteca-Chichimeca priests such as 4 Jaguar. Indeed, in later times even the Aztec emperor Motecuhzoma II was said to have valued his advice (Burgoa 1934 I: 320).

Although the key to further advances in the decipherment of Mixtec codices certainly lies in much needed ethnographic and archaeological field research, we must continue to examine how the codices themselves reflected the concerns of an ancient Mixtec aristocracy. The best research strategies can only emerge from a complete integration of all the available data, remembering that political as well as ritual symbolism will give us the most complete picture of Postclassic Mixtec society. 


\section{FOOTNOTES}

(1) We know that deity impersonation through costume was a widespread practice in Mesoamerica. For instance, the Aztec Cihuacoatl priest in Tenochtitlan was in fact a sacred position held by three successive generations of men, and wearing the regalia of the goddess during religious ceremonies. Given the lack of any personal identification depicted in ceremony or artwork in favor of the deity's own identification, confusion in the ethnohistorical record has arisen over which priest was impersonating the god. It is the sacred office and the deity concept that is emphasized and not the individual.

(2) Nuttall (1902) believed the manuscripts to be Aztec. Clark (1912) believed them to be Zapotec, and Spinden (1935) stated simply that they seemed to be from southern Mexico, although he did suggest the Mixteca.

(3) He was able to build his chronology from studies of Colonial notations. Wigberto Jiménez Moreno described the Lápida de Cuilapan, for example, which has codex-style dates inscribed with their Christian year equivalents (Jiménez Moreno and Mateos Higuera 1940).

(4) Nancy Troike's article, "Fundamental Changes in the Interpretations of the Mixtec Codices," discusses the main thrusts in Mixtec codex studies (Troike 1978).

(5) The indigenous Mesoamerican calendar was reckoned on the basis of a fifty-two year period at the end of which the year count was started over for the next cycle. It served in roughly the same capacity as our 100-year century. Unfortunately, the native pictorial artists did not feel compelled to distinguish one cycle from the next, leading to a considerable confusion on the contemporaneity of events (see also Appendix).

(6) Troike proved that Becker I is in fact the last half of the Colombino (Troike n.d.b.).

(7) The Borgia group of manuscripts are so-named after the Codex Borgia in the Vatican library, Rome. They seem to describe more specifically religious matters than the Mixtec group, since the tonalpoualli used for divination is a primary feature. The provenience of the Borgia pictorials has been a long-standing problem in Postclassic iconographic studies.

(8) Bruce Byland (1980: 151-157, 188-190) has discussed the complexities of Mixtec sociopolitical organization in the Tamazulapa Valley noting that the Early Postclassic (the Early Natividad period from A.D. 700 to A.D. 1000 or 1100) was characterized by a sudden shift toward decentralization and a system of diffuse leadership. His observation argues against 
the importance of increasing population size and agricultural intensification as a factor in the development of social complexity. In addition, the Postclassic Mixtec may even have adapted some distinctly chiefdom-like traits at this time (Spores 1983).

Byland proposed that rather than being reflective of cultural deterioration, the rise of factionalized elite estates may have been positively affected by new, long-distance trade connections and the emulation of an outside political system. He noted that by A.D. 1100, sites in the Tamazulapa Valley not only fission but share more artifactual traits with the northern city-states of Puebla and less with Monte Alban in the Valley of Oaxaca than they did in the Classic or Las Flores Period (A.D. 200-700). This suggests that the stimulation for change probably came from the Tehuacan Valley region through Coixtlahuaca. Codical evidence for a native comprehension of precisely this process is examined in Chapter V.

9 Maarten Jansen discusses Mixtec kings as deities (Jansen 1982a: 281-295).

10 See Smith (1983b:260-266) on regional points of view in the manuscripts.

11 Many authors have dealt with folk costume as pictorial communication in Latin America. Recent field work by Walter Morris and Patricia Anawalt in the Maya and Sierra de Puebla areas respectively is demonstrating that weaving patterns may even serve as mnemonic devices for the recitation of cycles of legends related to community boundaries and kinship group affiliation.

12 The fire serpent is a mythical saurian creature that possessed both serpent and lizard qualities. The term "fire" comes from its red and yellow coloration in frequent association with the flame/smoke symbols decorating its body. Depictions of the creature are widespread in the art of Monte Alban. The Aztec cognate was called a xiuhcoatl or "turquoise snake" (Nicholson 1983: 47). The Aztec deities Xiuhtecuhtli and Tepeyollotl sometimes appear wearing the tortoise-shell and fire-serpent headdress (Nicholson 1983: 87).

13 Fray Francisco de Burgoa was a seventeenth-century priest and vicar of Zaachila, Oaxaca. By publishing two major works on the history of the Dominican order in Oaxaca (Palestra Historial and Geográfica Descripción), he preserved much of our most valuable information on Pre-Columbian life of the Zapotec and Mixtecs.

14 The perception of "preferred" inheritance needs some qualification. For instance, primogeniture was not technically the system used by the first dynasty of Tilantongo. Power seems to have been transferred to first-born grandsons. Carlos Arostegui (personal communication) emphasizes two prerogatives for rulership. 
1. The successor must be a member of the royal class.

2. The successor must be the most direct descendant of the royal line.

The Mixtec maintained a highly stratified society organized into communities dominated by multiple kings, each seeking to expand their sphere of influence at the expense of their neighbors. Warfare, a constant threat, doubtless put pressure on local administrations to keep physically strong or extremely charismatic persons in high office. War would be just one of many factors that contributed to the need for forms of bureaucratic diversity, especially when matters of succession became critical and the qualifications of a first-born son would have to be evaluated. In dealing with succession, many anthropologists have found that idealized hereditary systems commonly do not fit the history of the actual passage of power (see Goody 1966).

15 Patterns of black dots on white backgrounds also appear. These refer to ashes or sand. The white flowers resemble the flowers identified by Smith (1973a: 79) with the term yuhu, which can also mean tomb. These are probably aromatic jasmine flowers (Byland and Pohl, in press). White flowers appear as a predominant theme in Mixteca-Puebla funerary ceramics. John Monaghan (n.d.a.) notes that white flowers represent the souls of the dead in the modern Mixtec community of Nuyoo.

16 Aside from the prolific use of sacred bundles in nearly all formal social gatherings, symbolism imbedded in legends and songs begs comparison to the Mixtec as well. The bringing of the first bundle through a hole in the sky (Fig. 3) is comparable to scenes in Zouche-Nuttall 1822 of the priests bringing the sacred bundles from heaven. The saga of the Blackfeet culture hero Scarface and his trip to see Father Sun includes an encounter with the white morning star warrior and a magical journey across a great foaming river or sea to the land of the ancestors. There, Scarface learns the Sun Dance that he brings back to herald a new era for the Blackfeet people. The story is striking in its similarities to Lord 8 Deer's journey to the sun god, 1 Death, with Priest 4 Jaguar and the institution of a new forms of ceremonialism.

17 Another merchant god is listed by Jiménez Moreno and Mateos Higuera (1940: 48-49) as toyna yoco. Toyna is a title; yoco can mean "wasp/bee," "honeycomb," or a "red headed eagle." Lord 8 Wind appears in Codex Selden 5III wearing a red headed eagle headdress possibly pointing to a title referring to the word yoco and cognate with his role as yaha yahui in Zouche-Nuttall 1-2. Yoco is also applied to the section of the Temple of Heaven precinct at Tilantongo called Toto Yoco. A substitute qualifier for the yoco place sign as a red-headed eagle (Pohl and Byland n.d.b.) appears as goods bound up for storage. These observations suggest that Toto Yoco may name a part of the site associated with mercantilism and the storage of elite goods, which would be presided over by the yaha yahui. 
18 Anne Dyk (1959) recorded a legend in which Juan is visited by the devil and taught to cure sickness as a means of making money. He then becomes the first Mixtec "Medicine Man". Perhaps the most famous "Juan" was Juan Diego, who witnessed the miraculous vision of the Virgin de Guadalupe. Juan Diego was a curer whose original name meant "the eagle that talks." Tim Knab (personal communication) was told by Gordon Wasson of a brujo in Loxicha, Oaxaca who would announce in the performance of certain rituals that he was St. John and that he had brought the mushroom.

19 During the fifty-two year cycle in which Lady 6 Monkey first appeared, the year 5 Reed came thirty years before her birth. Her marriage to 11 Wind came in the year 13 Rabbit, which is five years before the 5 Reed in the next-fifty two year cycle. Since the meeting with 9 Grass occurs before her marriage, the 5 Reed date must be a mistake and is probably meant to be 6 Reed.

20 The solar deity 1 Death was first described by Caso (1959) in his special study of the oracle. 1 Death is one of the Maya lords of the underworld in the Popol Vuh. Caso noted that 1 Death also had significant meanings both in the Mixtec and Aztec calendrical systems. For example, Alvarado (1962:190b) lists a Mixtec term for the sun as a heavenly body: yya caamaha, meaning Lord 1 Death. Examining the costume attributes of 1 Death on Zouche-Nuttall 78, we see that he wears a distinctive butterfly crown and the red body paint of the sun gods in the Borgia group (Spranz 1973: 316-334). Sahagún (1979: 33) said that for the Aztec, 1 Death was a day sign for Tetzcatlipoca, a deity discussed in Chapter 5 with special reference to the oracular priest, 4 Jaguar. 1 Death has a special relationship in the codices with both 4 Jaguar and Lord 8 Deer.

Caso originally thought that 1 Death might be the oracle of Tehuacan, while Jiménez Moreno suggested Teotitlan del Camino. These identifications were made on the basis of ethnohistoric evidence for powerful oracles in that region, and on a similarity in dress between 1 Death in the codices and the Xochipilli "xantile" polychrome images known from the Tehuacan Valley (see Map 7). 1 Death can now be correlated with Burgoa's (1934 I: 320, 332) descriptions of the oracle of Achiutla. As both Caso (1959) and Smith (1973a) have noted, 1 Death is located at Hill of the Sun in the codices. Abraham Castellanos (1910) recorded legends from the Valley of Achiutla involving the oracle there. He speaks of a temple of the sun god as located on Yucu Gandi (Yucu Ndicandi), meaning Hill of the Sun. In 1989, Bruce Byland and I identified Yucu Gandi as the primary Classic to Postclassic occupation of the Achiutla Valley. Jansen (1982a: 264) identified a Postclassic structure adjacent to the Colonial Church that is called the "House of the Sun".

21 Furst (1978a: 318, 1982: 207-225)) has discussed skeletal imagery in the Mixtec codices in some detail. She proposes that "death" imagery should be seen more as "life" imagery. Her 
point is well taken, for by far the majority of figures wearing skeletal jaws, clothing decorated with bones, and so forth, are involved with giving birth to founders and ancestors, with various fertility rituals, and with personified plants and trees. Although she calls attention to the seeming contradiction in using skeletal symbols for life-giving imagery rooted in shamanistic beliefs, she does not emphasize that the figures bear combinations of life and death imagery. The present discussion shows how these combinations actually imply "transition" or "transformation" from life to death and rebirth. It is not the skeletal attribute that needs redefining but a better understanding of the Mesoamerican concept of death.

22 Though the scroll pattern is not identifiable within the context of Mixtec art, it is well known as a death symbol among the Aztec and Maya.

23 In Origen de los Indios de el Nuevo Mundo e Indias Occidentales (Seler 1904: 289-290), Fray Gregorio García recorded an origin myth from Cuilapan that closely parallels the Borgia scene. Two gods named 1 Deer had two sons named "Wind Nine Snake" and "Wind Nine Cave". The word order can be transposed to produce 9 Wind "Snake" and 9 Wind "Cave," the calendrical names being those of the Mixtec creation hero (see Nicholson 1978:65). The brothers decided to make offerings to their ancestors with prayers in a garden they had created. To strengthen the prayers, they drew blood from their bodies and sprinkled it on all the trees they had planted.

The Borgia scene discussed here shows two deities taking blood from their genitals for just such a ritual. It is noteworthy that the "Macuilxochitl" figure on the left bears the same face paint pattern as the first-born male of the creator couple 1 Deer in Vindobonensis 51. The figure on the right bears the attributes of 9 Wind. Clearly, there is some association here between the Borgia characters and the creation scenes in Vindobonensis (see Furst 1978a: 55-71 and Jansen 1982a: 87).

24 Klein (1988) has discussed not only the symbolism inherent in Cihuacoatl's imagery but political aspects of female-skeletal imagery in Aztec art in general. She proposes that Cihuacoatl and deities related to her such as Coatlique, Coyolxauhqui, Toci, Chantico, and so forth, originally represented a state religious cult particularly associated with the southern regions bordering Lake Texcoco. Although no other deity is portrayed as often in Mexica art, many representations of Cihuacoatl are found on or at the bases of monumental art and building constructions in decidedly inferior display positions. Klein suggests that such positioning commemorates the historical defeat of the southern city-states by the Mexica and the defamation of the principal religious cult.

25 Art historians and archaeologists have long puzzled over the adoption of foreign symbol systems throughout ancient Mesoamerica, an inquiry that continues with studies of syncretic religious beliefs found throughout Mexico even today. Past theories have focused on outright 
invasions and the imposition of artistic conventions or symbols representative of new religious cults by outside conquerors. At one time, such misguided thinking led to hypotheses of lost Toltec empires. More recently, Flannery (1968) used the Shan-Kachin analogy to propose that the buying and selling of ritual was a fundamental reason symbol systems might be shared between different Mesoamerican co-traditions. Buying and selling ritual as a means of gaining political influence was widespread among the tribes of the United States historically. The Zuni and Hopi, for example, "purchased" dances from the Navajo for a variety of reasons both to facilitate trade relations and to defend themselves, through sympathetic magic, against Navajo raids. During these dances the Hopi and Zuni not only dress like Navajo dancers but sing in the Navajo language.

26 The transference of precious metals into first objects of art, as in the jewels of Martin Ocelotl, and later into commercially exchangeble ingots or coinage was a well known practice in the Old World. For example, the Classical Greeks gave tribute to the oracle at Delphi in the form of "gifts" of gold or silver statues in return for favorable prognostications. During times of national crisis, however, the Greek city-states unified themselves through their mutual veneration of the oracle's power. At such times the oracle's treasure was melted down and turned into coinage to pay troops. Profits made in seizing the enemy's valuables were then transformed back into offerings (plus interest) and "reinvested" in the oracle as sacred artwork.

Louis XIV similarly encouraged his noblemen to expend vast amounts of money on gold and silver decoration for Versailles. He then stripped the estate to finance the Wars of the Spanish Succession. Rather than being transformed into coinage to pay troops, Andrés Mixcoatl on the other hand, is demanding copper that could be transformed directly into war implements. Copper ingots of "mushroom" or "axe" money are found in very large quantities at Mitla. The implication is that New World oracles may have served in capacities not unlike national treasuries. 


\section{APPENDIX}

\section{DATING AND CHRONOLOGY}

Prominent persons found in the codices were named after their birthdays in the sacred 260 day calender. The system relied on the combination of a series of thirteen numerical dots with a series of twenty day signs. The day signs were:

$\begin{array}{ll}\text { Crocodile } & \text { Monkey } \\ \text { Wind } & \text { Grass } \\ \text { House } & \text { Reed } \\ \text { Lizard } & \text { Jaguar } \\ \text { Serpent } & \text { Eagle } \\ \text { Death } & \text { Vulture } \\ \text { Deer } & \text { Movement } \\ \text { Rabbit } & \text { Flint } \\ \text { Water } & \text { Rain } \\ \text { Dog } & \text { Flower }\end{array}$

The count began with the first day of the year, 1 Crocodile, and proceeded with a normal numerical progression. After 13 Reed was reached the numerical count started all over again. Thus, the day following 13 Reed was 1 Jaguar. When the day Flower was reached, it was time to start counting the day Crocodile over again with its corresponding number. Accordingly, 8 Crocodile was the twenty-first day of the year. 
The Mixtec named their years and bound them into fifty-two year cycles. The pictorial motif for a year was an interlaced "A-O" sign. Each year was accompanied by one of four year bearers:

House

Rabbit

Reed

Flint

Like the day count, the year count employed thirteen numerical dots.

The sequence of year signs in two fifty-two year cycles is listed in order to facilitate more easily the juxtaposition of contemporaneous historical events surrounding the 8 Deer story. The Codex Zouche-Nuttall, for example, is fairly consistent in naming principal figures but often leaves out key year dates. The Codex Bodley, on the other hand, is very specific in giving the year of a person's birth and even connecting that person to the "A-O" glyph with a symbolic "umbilical cord."

Emily Rabin (n.d.b.) proposed that the chronology that Caso designed for his interpretation of Codices Selden, Colombino-Becker, and Bodley incorrectly joined end-to-end events that were actually contemporaneous. Through careful cross-referencing, Rabin was able to link people and events that Caso thought were a generation or more apart. For instance, Caso believed that 5 Crocodile, 8 Deer's father, succeeded 2 Rain as ruler of Tilantongo. Rabin, however, has called attention to the marriage of Lord 10 Eagle of Tilantongo and Lady 9 Wind of Jaltepec in Bodley $6 \mathrm{~V}$ and Selden $5 \mathrm{IV}$. These persons are known to have lived before 2 Rain, but were contemporaries of 5 Crocodile. A reassessment of the sequence of events then shows that 5 Crocodile died thirteen years before 2 Rain; he could not have succeeded him as a ruler of Tilantongo.

The juxtaposition of events puts 2 Rain together with 8 Deer and 6 Monkey. Nancy Troike points to the fact that 8 Deer began his negotiations with 4 Jaguar to receive the turquoise nose ornament directly after the mysterious death of 2 Rain in year 6 Flint (Bodley 5I). I argue that the award of the ornament is a symbolic device making 8 Deer a lineage head and hence eligible to found a new dynasty at Tilantongo (Zouche-Nuttall 52). After his halfbrother 12 Movement is also mysteriously assassinated in the year 10 flint (Becker 5I), 8 Deer attacks Red and White Bundle where he sacrifices Lady 6 Monkey, her husband 11 Wind, and later two of his sons from a previous marriage. The latter were 8 Deer's two half-nephews, 10 Dog and 6 House (Zouche-Nuttall 83). In the year 13 Reed, 8 Deer marries the sister of 10 Dog and 6 House (Bodley 11I), presumably uniting the Red-and-White Bundle dynasty with his 
own lineage. 8 Deer is at this time shown seated on the Tilantongo place sign as the founder of the second dynasty there. According to Codex Bodley, he is the first person shown as ruler since 2 Rain's grandfather. Later 8 Deer is sacrificed by 4 Wind, the son of 6 Monkey and 11 Wind, in the year 12 Reed (Colombino 16II). Finally, 4 Wind marries the daughter of 8 Deer and Lady 13 Serpent, Lady 10 Flower (Selden 8 IV, Bodley 30 IV).

This sequence of events characterized by warfare, sacrifices, assassinations, and meetings with oracular priests all point to a period of tremendous upheaval in the politics of the Mixteca, particularly in the southern end of the Nochixtlan Valley, where Mixtec kingdoms found themselves playing the roles of middlemen between Tolteca-Chichimeca confederacies to the north and the Zapotec inheritors of Monte Alban's authority in the Valley of Oaxaca to the south. Although we may never unravel completely the mystery of what the history of these events actually signified, the cause-and-effect situations are typical of escalating competition for the control of pivotal power centers in state societies. For a more complete analysis of the lives of 8 Deer, Lady 6 Monkey, and 4 Wind, the reader should examine Caso's commentary of the Codex Bodley (Caso 1960) and Nancy Troike's commentary of Codex Colombino-Becker (Troike n.d.b.) 
CYCLE A

1 Reed

2 Flint

3 House

4 Rabbit Lord 9 Wind of Tilantongo marries Lady 5 Reed of Hill of the Wasp

5 Reed

6 Flint Lord 10 Flower of Tilantongo is born

7 House

8 Rabbit

9 Reed

10 Flint

11 House

12 Rabbit

13 Reed

1 Flint

2 House

3 Rabbit

4 Reed

5 Flint

6 House

7 Rabbit

8 Reed

9 Flint

10 House

11 Rabbit

12 Reed

13 Flint

1 House Lord 10 Flower of Tilantongo marries Lady 2 Serpent of Suchixtlan.

2 Rabbit

3 Reed

4 Flint

5 House

6 Rabbit

7 Reed

8 Flint

9 House

10 Rabbit

11 Reed 
12 Flint

13 House Lord 5 Crocodile initiates rituals at the Temple of Heaven at Tilantongo

1 Rabbit

2 Reed

3 Flint

4 House

5 Rabbit

6 Reed

7 Flint

8 House

9 Rabbit

10 Reed

11 Flint

12 House

13 Rabbit 


\section{CYCLE B}

1 Reed

2 Flint

3 House Lord 10 Eagle of Tilantongo marries Lady 9 Wind of Suchixtlan at Jaltepec

4 Rabbit

5 Reed Lord 5 Crocidile marries Lady 11 Water

6 Flint

7 House Lord 12 Movement is born

8 Rabbit

9 Reed

10 Flint

11 House

12 Rabbit

13 Reed

1 Flint

2 House

3 Rabbit

4 Reed

5 Flint

6 House

7 Rabbit

8 Reed

9 Flint

10 House

11 Rabbit

12 Reed Lord 8 Deer is born.

13 Flint

1 House

2 Rabbit

3 Reed Lord 9 Flower is born.

4 Flint

5 House

6 Rabbit

7 Reed

8 Flint

9 House Lady 6 Monkey is born.

10 Rabbit

11 Reed Lord 2 Rain is born.

12 Flint 
13 House

1 Rabbit

2 Reed

3 Flint

4 House

5 Rabbit 5 Crocodile dies

6 Reed 8 Deer and Lady 6 Monkey meet the oracle priest Lady 9 Grass

7 Flint

8 House

9 Rabbit

10 Reed

11 Flint

12 House

13 Rabbit Lord 11 Wind of Red and White Bundle marries Lady 6 Monkey 


\section{CYCLE C}

1 Reed

2 Flint Lord 4 Wind, son of Lady 6 Monkey of Jaltepec is born.

3 House

4 Rabbit

5 Reed

6 Flint Lord 2 Rain dies.

7 House Lord 8 Deer meets with 4 Jaguar who awards the nose ornament.

8 Rabbit

9 Reed 8 Deer meets with oracular priest 1 Death.

10 Flint Lord 12 Movement, 8 Deer's brother is assassinated.

11 House Lord 8 Deer attacks Red and White Bundle and kills Lady 6 Monkey and 11 Wind.

12 Rabbit Lords 10 Dog and 6 House are sacrificed.

13 Reed

1 Flint

2 House Lord 4 Wind meets with oracular priest 1 Death.

3 Rabbit

4 Reed

5 Flint

6 House

7 Rabbit

8 Reed

9 Flint

10 House

11 Rabbit

12 Reed Lord 8 Deer is sacrificed (by Lord 4 Wind?).

13 Flint

1 House

2 Rabbit

3 Reed 4 Wind receive nose ornament from 4 Jaguar.

4 Flint 4 Wind succeeds to Place of Flint.

5 House

6 Rabbit

7 Reed

8 Flint 4 Wind marries Lady 10 Flower, 8 Deer's daughter.

9 House

10 Rabbit

11 Reed 
12 Flint

13 House

1 Rabbit

2 Reed

3 Flint

4 House

5 Rabbit

6 Reed

7 Flint

8 House

9 Rabbit

10 Reed

11 Flint

12 House

13 Rabbit 


\section{BIBLIOGRAPHY}

Acuña, René

1984 Relación de Tilantongo. In: Relaciones geográficas del siglo XVI: Antequera, Volume II. Edited by René Acuña. México: Universidad Nacional Autónoma de México.

1985a Relación de Acatlán. In: Relaciones geográficas del siglo XVI: Tlaxacala, Volume II. Edited by René Acuña. Mexico: Universidad Autonoma de Mexico.

1985b Relación de Cuzcatlan. In Relaciones geográficas del siglo XVI: Tlaxcala, Volume II. Edited by René Acuña. México: Universidad Autónoma de México.

Alarcon, Hernando Ruiz de

1984 Treatise on the Heathen Superstitions that Today Live among the Indians Native to this new Spain. Translated and edited by J. Richard Andrews and Ross Hassig. Norman: University of Oklahoma Press.

Alvarado, Francisco de

1962 Vocabulario en Lengua Mixteca. Reproduccion facsimilar con un estudio de Wigberto Jiménez Moreno. Mexico: Instituto Nacional Indigenista e Instituto Nacional de Antropología e Historia.

Anawalt, Patricia Rieff

1981 Indian Clothing Before Cortes. Mesoamerican Costumes from the Codices. Norman: University of Oklahoma Press.

1990 The Emperor's Cloak: Aztec Pomp, Toltec Circumstance. American Antiquity 55 (2): pp. 291-307.

Arana, Evangelina, and Mauricio Swadesh

1965 Los elementos del mixteco antiguo. México: Instituto Nacional Indigenista and Instituto Nacional de Antropología e Historia.

Baird, Ellen Taylor

n.d. Sahagún's Primeros Memoriales: A Structural and Stylistic Analysis of the Drawings. Unpublished Ph.D. dissertation. University of New Mexico. Manuscript in author's possession. 
Barlow, Robert

1954 Las joyas de Martín Ocelotl. YAN (3) pp. 56-59.

Berdan, Frances F.

1982 The Aztecs of Central Mexico: An Imperial Society. New York: Holt, Rinehart, Winston.

Berlin, Heinrich

1947 Fragmentos desconocidos del Códice de Yanhuitlán y otras investigaciones. México: Jose Porrúa.

Bernal, Ignacio

1948 Exploraciones en Coixtlahuaca, Oaxaca. Revista Mexicana de Estudios Antropológicos. Tomo Décimo, pp. 5-76.

Bittman Simons, Bente

1968 Los Mapas de Cuauhtinchan y la Historia Tolteca-Chichimeca. Serie Investigaciones No. 15. México: Instituto Nacional de Antropología e Historia.

Bittman, Bente, and Thelma Sullivan

1979 The Pochteca. In: Mesoamerican Communication Routes and Cultural Contacts. pp. 211-218. Edited by Thomas A. Lee and Carlos Navarrete. Provo: Brigham Young University, New World Archaeological Foundation.

Bohannan, Laura

1952 A Genealogical Charter. Africa 22(4), pp. 301-315.

Boone, Elizabeth

n.d. A Reevaluation of the "Coatlique." Manuscript in author's possession.

1983 The Codex Magliabechiano and the Lost Prototype of the Magliabechiano Group. Two Volumes. Berkeley: University of California Press.

Brown, Betty Ann

1988 Mixtec Masking Traditions: Juxtlahuaca, Mexico. In: Behind the Mask in Mexico (245-261). Edited by Janet Brody Esser. Santa Fe: Museum of New Mexico Press. 
Brumfiel, Elizabeth

1989 Factional Competition in Complex Society. In Domination and Resistence. Edited by Daniel Miller, Michael Rowlands, Christopher Tilley (pp. 127-139). London: Unwin Hyman

Bullchild, Percy

1985 The Sun Came Down: The History of the World as My Blackfeet Elders Told It. San Francisco: Harper and Row.

Burgoa, Francisco de

1934 Geográfica descripción. Vols. XXV-XXVI. México: Publicaciones del Archivo General de la Nación.

Burkhart, Louise

1989 The Slippery Earth: Nahua-Christian Moral Dialogue in Sixteenth Century Mexico. Tucson: University of Arizona Press.

Byland, Bruce E.

n.d. Political and Economic Evolution in the Tamazulapan Valley, Mixteca Alta, Oaxaca, Mexico: A Regional Approach. 1980 Ph.D. dissertation. Pennsylvania State University. Manuscript in author's possession.

Byland, Bruce E. and John M.D. Pohl

n.d. Political Factions in the Transition from Classic to Postclassic in the Mixteca Alta. To be included in a forthcoming Cambridge University Press Press Volume on Factionalism in Ancient Mesoamerica. Edited by Elizabeth Brumfiel and John Fox.

In press: In the Realm of 8 Deer: The Archaeology of the Mixtec Codices. Norman: University of Oklahoma Press.

\section{Carrasco, Pedro}

1966 Rango de tecuhtli entre Los Nahuas Tramontanos. Tlalocan 5(2); 133-160.

1971 Social Organization of Ancient Mexico. In: Handbook of Middle American Indians. Edited by Robert Wauchope. Vol. 10, pp. 349-375. Austin: University of Texas Press.

1974 La Matrícula de Huexotzinco como fuente sociológica. In: Matrícula de Huexotzinco. pp. 1-16. Edited by Hans J. Prem. Graz: Akademische Druck. 
Carrasco, Pedro; Johanna Broda et al.

1976 Estratificación social en la mesoamerica prehispánica. México: Instituto Nacional de Antropologiá e Historia.

\section{Caso, Alfonso}

1938 Exploraciones en Oaxaca: Quinto y Sexta temporados, 1936-1937. México: Instituto Panamericano de Geografía e Historia. Publicación 34.

1949 El Mapa de Teozacoalco. Cuadernos americanos VIII (5: pp. 145-181). Mexico: Editorial Cultura T.G.S.A.

1958 The Aztecs, People of the Sun. Norman: University of Oklahoma Press.

1959 El Dios 1 Muerto. Mitteilungen aus dem Museum für Völkerkunde und Vorgeschite 25: 40-43.

1960 Interpretation of the Codex Bodley 2858. Mexico: Sociedad Mexicana de Antropología.

1961a Nombres Calendaricos de los Dioses. El México Antiguo 10: pp. 77-100.

1961b Los lienzos mixtecos de Ihuitlán y Antonio de Leon. In: Homenaje a Pablo Martínez del Río en el vigésimoquinto aniversario de la primera edición de Los Origenes Americanos. pp. 237-274. México: Instituto Nacional de Antropología e Historia.

1962 Vocabulario Sacando del Arte en Lengua Mixteca de Fray Antonio de los Reyes. In: Vocabulario en Lengua Mixteco por Fray Francisco de Alvarado. Reproducción facsimilar con un estudio de Wigberto Jiménez Moreno. México: Instituto Nacional Indigenista e Instituto Nacional de Antropología e Historia.

1964 Interpretation of the Codex Selden 3135. México: Sociedad Mexicana de Antropología.

1966 Interpretation of the Codex Colombino. México: Sociedad Mexicana de Antropología.

1969 El tesoro de Monte Albán. Memorias del Instituto Nacional de Antropología e Historia 3. México: Instituto Nacional de Antropología e Historia. 
1977 Reyes y reinos de la mixteca. Volume I. México: Fondo de Cultura Económica.

1979 Reyes y reinos de la mixteca. Volume II: Diccionario biografico de los Senores Mixtecos. México: Fondo de Cultura Económica.

Castellanos, Abraham

1910 El Rey Iukano y los hombres del oriente: Leyenda inspirada en los restos del "Códice Colombino." México: A. Carranza e Hijos.

Chamberlain, Von del

1982 When Stars Came Down to Earth. Cosmology of the Skidi Pawnee Indians of North America. Los Altos: Ballena Press Anthropological Papers No. 26.

\section{Clark, James Cooper}

1912 The Story of "8 Deer" in Codex Colombino. London.

Cobean, Robert H., and Alba Guadalupe Mastache

1989 The Late Classic and Early Postclassic Chronology of the Tula Region. In: Tula of the Toltecs: Excavations and Survey. pp. 34-46. Edited by Dan M. Healan. Iowa City: University of Iowa Press.

Cohen, Abner

1976 Two-Dimensional Man: An Essay on the Anthropology of Power and Symbolism in Complex Society. Berkeley: University of California Press.

\section{Cordry, Donald}

1980 Mexican Masks. Austin: University of Texas Press.

Cordry, Donald, and Dorothy Cordry

1968 Mexican Indian Costumes. Austin: University of Texas Press.

Dahlgren, Barbro

1954 La Mixteca: su cultura e historia prehispánica. México: Imprenta Universitaria.

Davies, Nigel

1977 The Toltecs. Norman: University of Oklahoma Press.

1980 The Toltec Heritage. Norman: University of Oklahoma Press. 
Dennis, Bryan J.

n.d. Establishing the Mixtec Dynasties of the Tilantongo Valley: An Interpretation of Codex Zouche-Nuttall Pages 14-22. 1990 UCLA Unpublished Master's Thesis. Manuscript in author's possession.

Durán, Diego

1964 The Aztecs: The History of the Indies of New Spain. Translated with notes by Doris Heyden and Fernando Horcasitas. New York: Orion Press.

1971 Book of the Gods and rites and the Ancient Calendar. Translated and edited by Fernando Horcasitas and Doris Heyden. Norman: University of Oklahoma Press.

Dyk, Anne

1959 Mixteco Texts. Summer Institute of Linguistics Series 3. Norman: University of Oklahoma Press.

Flannery, Kent

1968 The Olmec and the Valley of Oaxaca: A Model for Inter-Regional Interaction in Formative Times. In: Dumbarton Oaks Conference on the Olmec. pp.79-110. Edited by Elizabeth Benson. Washington D.C.: Dumbarton Oaks.

Flannery, Kent and Joyce Marcus

1983 The Origins of the State in Oaxaca. In: The Cloud People: Divergent Evolution of the Zapotec and Mixtec Civilizations (79-83). New York: Academic Press.

Fortes, M. and E.E. Pritchard

1975 African Political Systems. London: Oxford University Press.

Fried, Morton $\mathrm{H}$.

1960 On the Evolution of Social Stratification and the State. In: Culture in History. Edited by S. Diamond. pp. 713-731. New York: Columbia University Press.

1967 The Evolution of Political Society: An Essay in Political Anthropology. New York: Random House.

Furst, Jill Leslie

1978a Codex Vindobonensis Mexicanus I: A Commentary. Albany: State University of New York Institute for Mesoamerican Studies. Publication No. 4 
1978b The Life and Times of 8 Wind "Flinted Eagle." Alcheringa Vol. 4(1) pp. 2-37.

1982 Skeletonization in Mixtec Art: A Re-evaluation. In: The Art and Iconography of Late Post-Classic Central Mexico. pp. 207-225. Edited by Elizabeth Benson. Washington, D.C.: Dumbarton Oaks.

1986 The Lords of "Place of the Ascending Serpent": Dynastic Succession on the Nuttall Obverse. In: Symbol and Meaning Beyond the Closed Community: Essays in Mesoamerican Ideas. Studies on Culture and Society. Vol. 1: pp. 57-68. Edited by Gary H. Gossen. Albany: Institute for Mesoamerican Studies, State University of New York.

\section{Furst, Peter T.}

1972 To Find Our Life: Peyote Among the Huichol Indians of Mexico. In: Flesh of the Gods: The Ritual Use of Hallucinogens (pp. 136-184). Edited by Peter t. Furst. New York: Praeger Publishers.

\section{Gallegos Ruiz, Roberto}

1962 Exploraciones en Zaachila, Oaxaca. Boletín del Instituto Nacional de Antropología e Historia. No. 8: 6-8.

Garibay K., Ángel Ma.

1979 Teogonía e historia de los mexicanos: Tres opúsculos del siglo XVI. México: Editorial Porrua.

Gelb, I.J.

1963 A Study of Writing. Chicago: University of Chicago Press.

Gerhard, Peter

1972 A Guide to the Historical Geography of New Spain. Cambridge: Cambridge University Press.

Gibson, Charles

1971 Structure of the Aztec Empire. In: Handbook of Middle American Indians. Edited by Gordon F. Ekholm and Ignacio Bernal. Volume 10, pp. 376-393. Austin: University of Texas Press.

Goldman, Irving

1970 Ancient Polynesian Society. Chicago: University of Chicago Press. 
Goody, Jack

1966 Succession to High Office. Cambridge Papers in Social Anthropology, No. 4.

Edited by Jack Goody. Cambridge: Cambridge University Press.

Graulich, Michel

1974 Las Peregrinaciones aztecas y el ciclo de Mixcóatl. Estudios de Cultura Nahuatl 11:311-354.

Greenleaf, Richard E.

1969 The Mexican Inquisition of the Sixteenth Century. Albuquerque: University of New Mexico Press.

Gruzinsky, Serge

1989 Man-Gods in the Mexican Highlands: Indian Power and Colonial Society, 15201800. Stanford: Stanford University Press.

Hall, James

1974 Dictionary of Subjects and Symbols in Art. New York: Harper and Row.

Hassig, Ross

1988 Aztec Warfare: Imperial Expansion and Political Control. Norman: University of Oklahoma Press.

Herrera, Antonio de

1945 Historia general de los hechos de los Castellanos, en las islas, y tierra-firme de el mar océano. Vol. IV. Buenos Aires: Editorial Guarania.

Hosler, Dorothy, Heather Lechtman, and Olaf Holm

1990 Axe-Monies and their Relatives. Dumbarton Oaks Studies in Pre-Columbian Art and Archaeology, Number 30. Washington, D.C.: Dumbarton Oaks.

Ixtlilxochitl, Fernando de Alva

1965 Obras históricas. 2 Vols. México: Editoria Nacional.

Jansen, Maarten E.R.G.N.

n.d. El lugar donde estaba el cielo. 1976 Master's Thesis. University of Leiden, Holland. 
1980 Tnuhu Niquidza Iya. Temas principales de la historiografía Mixteca. Ediciones del Gobierno Constitutional del Estado de Oaxaca. Dirección General de Social de Oaxaca, Oaxaca.

1982a Huisi Tacu, estudio interpretivo de un libro mixteco antiguo: Codex Vindobonenesis Mexicanus I. Amsterdam: CEDLA, Incidentale Publicaties 24, Vols. 1 and 2.

1982b Viaje al otro mundo: La Tumba I de Zaachila. In: Los indígenas de méxico en la epoca precolombina y en la actualidad. pp. 87-119. Leiden: Rijksmuseum voor Volkenkunde.

1989 Nombres históricos e identidad etnica en los códices mixtecos. Revista Europea de Estudios Latinamericanos y del Caribe. 47: 65-87.

1990 The Search for History in Mixtec Codices. Ancient Mesoamerica. Vol. 1(1) pp. 99112.

Jiménez Moreno, Wigberto

1954-55 Síntesis de la historia precolonial del Valle de México. Revista Mexicana de Estudios Antropológicos. Vol. 14(I): 219-236.

Jiménez-Moreno, Wigberto and Salvador Mateos Higuera

1940 Códice de Yanhuitlan. Mexico: Museo Nacional del INAH.

Johnson, Allen W., and Timothy Earle

1987 The Evolution of Human Societies: From Foraging Group to Agrarian State. Stanford: Stanford University Press.

Joralemon, David

1981 The Old Woman and the Child: Themes in the Iconography of Preclassic Mesoamerica. In: The Olmec and Their Neighbors: Essays in Memory of Matthew W. Stirling. Organized by Michael D. Coe and David Grove. Edited by Elizabeth P.

Benson. Washington D.C.: Dumbarton Oaks.

King, Mark B.

n.d. Historical Metaphor and the Communication of Legitimacy in the Mixteca 500 B.C.-A.D. 1500. 1982. Vanderbilt University unpublished Master's thesis. Manuscript in author's possession. 
Kirchhoff, Paul

1952 Mesoamerica: Its Geographic Limits, Ethnic Composition and Cultural Characteristics. In: Heritage of Conquest: The Ethnology of Middle America. pp. 1730. Edited by Sol Tax and Members of the Viking Fund Seminar on Middle American Ethnology. Glencoe: The Free Press.

Kirchhoff, Paul, Lina Odena Güemes, and Luis Reyes García 1976 Historia Tolteca-Chichimeca. México: Instituto Nacional de Antropología e Historia.

Klein, Cecilia

1984 Dioses de la Lluvia o sacerdotes ofrendadores del fuego? Un estudio de algunas representaciones mexicas del dios Tlaloc. Estudios de Cultura Nahuatl 17: pp. 33-50.

1988 Rethinking Cihuacoatl: Aztec Political Imagery of the Conquered Woman. In: Smoke and Mist: Mesoamerican Studies in Memory of Thelma D. Sullivan. Edited by J. Kathryn Josserand and Karen Dakin. Oxford: BAR International Series 402(i).

Klor de Alva, J. Jorge

1981 Martin Ocelotl: Clandestine Cult Leader. In: Struggle and Survival in Colonial America. pp. 128-141 Edited by David Sweet and Gary Nash. Berkeley: University of California Press.

Konig, Viola

1984 Der Lienzo Seler II und Seine Stellung Innerhalb der Coixtlahuaca Gruppe. Baessler-Archiv, Neue Folge, Band XXXII. Berlin: Von Dietrich Reimer.

Leach, E.R.

1965 Political Systems of Highland Burma. Boston: Beacon Press.

Lehmann, Walter, and Ottokar Smital

1929 Codex Vindobonensis Mexicanus I. Facsimileausgabe der Mexikanischen Bilderhandschrift der Nationalbibliotek in Wien. Vienna.

León Portilla, Miguel

1969 Pre-Columbian Literatures of Mexico. Norman: University of Oklahoma Press. 
1970 Aztec Thought and Culture, A Study of the Ancient Nahuatl Mind. Norman: University of Oklahoma Press.

Lind, Michael

n.d. The Great City Square: Government in Ancient Cholula. Unpublished manuscript in author's possession.

Lind, Michael, and Javier Urcid

1991 The Lords of Lambityeco and their Nearest Neighbors. Notas mesoamericanas No. 9, pp. 78-111.

MacNeish, Richard S., Frederick A. Peterson and Kent V. Flannery.

1970 The Prehistory of the Tehucan Valley: Ceramics. Volume 3. Austin: University of Texas Press.

MacNeish, Richard S.; Melvin L. Fowler, Angel Garcia Cook, Frederick A. Peterson, Antoinette Nelken-Terner, and James A. Neely

1972 The Prehistory of the Tehuacan Valley: Excavation and Reconnaissance. Volume 5. Austin: University of Texas Press.

Marcus, Joyce

1978 Archaeology and Religion: A Comparison of the Zapotec and Maya. World Archaeology Vol. 10(2) pp. 172-191.

1983a The Conquest Slabs of Building J, Monte Alban. In: The Cloud People: Divergent Evolution of the Zapotec and Mixtec Civilizations. pp. 106-108. Edited by Kent Flannery and Joyce Marcus. New York: Academic Press.

1983b Zapotec Religion. In: The Cloud People: Divergent Evolution of the Zapotec and Mixtec Civilizations. pp. 345-351. Edited by Kent Flannery and Joyce Marcus. New York: Academic Press.

1992 Mesoamerican Writing Systems: Propaganda, Myth and History in Four Ancient Civilizations. Princeton: Princeton University Press.

\section{Matos Moctezuma, Eduardo}

1974 Proyecto Tula, primera parte. México: Instituto Nacional de Antropología e Historia: Collecion Cientifica 15. 
McClintock, Walter

1935 The Blackfoot Beaver Bundle. Southwest Museum Leaflets Nos. 2 and 3. Los Angeles: Southwest Museum

1938 Blackfoot Warrior Societies. Southwest Museum Leaflets No. 8. Los Angeles: Southwest Museum.

Mendelson, E. Michael

1958 A Guatemalan Sacred Bundle. Man Vol. LVIII (170) pp. 121-126.

Monaghan, John

1990a Performance and the Structure of the Mixtec Codices. Ancient Mesoamerica. Vol. 1(1) pp. 133-140.

1990b Sacrifice, Death, and the Origins of Agriculture in the Codex Vienna. American Antiquity 55(3) pp. 559-569.

n.d.a. "We Are People Who Eat Tortillas:" Household and Community in the Mixteca. 1987. University of Pennsylvania unpublished Ph.D. thesis. Manuscript in author's possession.

n.d.b. Sacrifice and the Symbolics of Power in Ancient Mesoamerica. Manuscript in author's possession.

Moser, Christopher L.

1983 A Postclassic Burial Cave in the Southern Canada. In: The Cloud People: Divergent Evolution of the Zapotec and Mixtec Civilizations. pp. 270-272. Edited by Kent Flannery and Joyce Marcus. New York: Academic Press.

Motolonía, Toribio de

1903 Memoriales. Published by Luis García Pimentel from a manuscript in the collection of Joaquin García Icazbalceta. México.

1951 Motolonía's History of the Indians of New Spain. Translated and Edited by Elizabeth Andros Foster. Berkeley: The Cortes Society.

Muñoz-Camargo, Diego

1986 Historia de Tlaxcala. Madrid: Hermanos Garcia Noblejas. 
Myerhoff, Barbara G.

1974 Peyote Hunt; The Sacred Journey of the Huichol Indians. Ithaca: Cornell University Press.

Nicholson, H.B.

n.d. The Provenience of the Codex Borbonicus: an Hypothesis. Unpublished manuscript in possession of author.

1966 The Mixteca-Puebla Concept in Mesoamerican Archaeology: A Re-Examination. In: Ancient Mesoamerica. Edited by John A. Graham. pp. 258-263. Palo Alto: Peek Publications.

1967 Review of Alfonso Caso, Interpretación del Códice Selden 3135 (A.2)/ Interpretation of the Codex Selden 3135 (A.2). American Antiquity 32 (2): 257-258.

1971a Religion in Pre-Hispanic Central Mexico. In: Handbook of Middle American Indians. Vol. 10: 395-446. Edited by Gordon Ekholm and Ignacio Bernal. Austin: University of Texas Press.

1978 The Deity 9 Wind "Ehecatl-Quetzalcoatl" in the Mixteca Pictorials. Journal of Latin American Lore. 4(1): 61-92.

1982 The Mixteca-Puebla Concept Revisited. In: Dumbarton Oaks Conference on the Art and Iconography of Late Postclassic Central Mexico. Edited by Elizabeth Boone. pp. 227-254. Washington D.C: Dumbarton Oaks.

Nicholson, H.B. with Eloise Quinones Keber

1983 Art of Aztec Mexico: Treasures of Tenochtitlan. Washington, D.C.: National Gallery of Art.

Noguera, Eduardo

1950 El horizonte tolteca-chichimeca. Enciclopedia mexicana de arte No. 4. México: Ediciones Mexicanas.

Nowotny, Karl Anton

1949 A Unique Wooden Figure From Ancient Mexico. American Antiquity. Volume XV (1) pp. 57-61. 
Nuttall, Zelia

1902 Codex Nuttall: Facsimile of an Ancient Mexican Codex Belonging to Lord Zouche of Haryngworth. Cambridge: Harvard University, Peabody Museum of American Archaeology and Ethnology.

\section{Olivera, Mercedes}

1978 Pillis y Macehuales: Las formaciones sociales y los modos de producción de tecali del Siglo XII al XVI. México: Ediciones de la Casa Chata.

Paddock, John

1983 Lord 5 Flower's Family: Rulers of Zaachila and Cuilapan. Vanderbilt University Publications in Anthropology No. 29. Nashville: Vanderbilt University.

Parmenter, Ross

1964 Week in Yanhuitlan. Albuquerque: University of New Mexico Press.

1982 Four Lienzos of the Coixtlahuaca Valley. Dumbarton Oaks Studies in PreColumbian Art and Archaeology No. 26. Washington D.C: Dumbarton Oaks.

Pastor, Rodolfo

1987 Campesinos y reformas: La Mixteca 1700-1856. México: El Colegio de México.

Paso y Troncoso, Francisco del

1905 Papeles de Nueva España. Secunda serie: Vol. IV, Relaciones geográficas de la diocesis de Oaxaca. Madrid: Est. Tipografico.

Pickett, Velma

1959 Castellano-Zapoteco y Zapoteco-Castellano, Dialecto del Zapoteco del Istmo, Serie de vocabularios indígenas Mariano Silva y Aceves 3. México: Secretaria de Educación Pública.

Pohl, John M.D.

n.d. Political and Iconographic Considerations in the Removal of Male 10-Dog and Male 6-House by Male 8-Deer. 1978 UCLA unpublished Master's thesis. Manuscript in author's possession.

in press Mexican Codices, Maps and Lienzos as Social Contracts. In Records without Words. Edited by Elizabeth Boone and Walter Mignolo. Durham: Duke University Press. 
1991 Ancient Armies of Mexico: The Aztecs, Mixtecs, and Zapotecs. London: George Phillip.

Pohl, John M.D., and Bruce E. Byland

n.d.a. Xipe Totec and Zapotec Lordship. Manuscript in author's possession.

n.d.b. The Temple of Heaven in the Mixtec Codices. Manuscript in author's possession.

1990 Mixtec Landscape Perception and Archaeological Settlement Patterns. Ancient Mesoamerica Vol. 1 (1): pp. 113-131.

Pohl, Mary Deland, and John M.D. Pohl

in press Cycles of Conflict: Political Factionalism in the Maya Lowlands. To be included with a forthcoming Cambridge University Press volume on factionalism in Ancient Mesoamerica. Edited by Elizabeth Brumfiel and John Fox.

1983 Ancient Maya Cave Rituals. Archaeology 36(3) pp.28-32, 50-51.

Procesos de indios idolatras y hechizeros

1912 México: Publicaciones del Archivo General de la Nación.

Rabin, Emily

n.d.a. Some Problems of Chronology in the Mixtec Historical Manuscripts, Part 1. Paper presented at the XLI International Congress of Americanists, Mexico 1974.

n.d.b. Some Problems of Chronology in the Mixtec Historical Manuscripts, Part II. Paper read at the Second Cambridge Symposium on Recent Research in Mesoamerican Archaeology. Cambridge 1976.

1979 The War of Heaven in Codices Zouche-Nuttall and Bodley: A Preliminary Study. In Actes du XLII Congrés International des Américanistes, Paris. Vol. VII: pp. 171-182.

Rattray, Evelyn C.

1966 An Archaeological and Stylistic Study of Coyotlatelco Pottery. Mesoamerican Notes 7-8. Mexico: Department of Anthropology, University of the Americas.

Rattray, R.S.

1929 Ashanti Law and Constitution. Oxford: Clarendon Press. 
Ravicz, Marilyn Ekdahl

1970 Early Colonial Religious Drama in Mexico: From Tzompantli to Golgotha. Washington D.C.: Catholic University of America Press.

Ravicz, Robert

1961 La Mixteca en el estudio comparativo del hongo alucinante. en: Anales del Instituto Nacional de Antropología e Historia. XIII pp.73-92.

Ravicz, Robert, and Kimball Romney

1969 The Mixtec. In: Handbook of Middle American Indians. Edited by Evon Vogt. Vol.7, pp. 367-399

Reeves, B.O.K.

1993 Iniskim: A Sacred Nitsitapii Religious Tradition. In: Kunaitupii: Coming Together on native Sacred Sites, Their Sacredness, Conservation, and Interpretation. Edited by Brian O.K. Reeves and Margaret A. Kennedy. pp. 194- 259. Calgary: Archaeological Society of Alberta.

1978 Head-Smashed-In: 5500 Years of Bison Jumping in the Alberta Plains. Plains Anthropologist. Memoir 14 (23-82 pt.2) pp. 151-174.

Reyes, Antonio de los

1976 Arte en lengua mixteca. Nashville: Vanderbilt University Publications in Anthropology No. 14 .

Reyes, Luis García

1977 Cuauhtinchan del Siglo XII al XVI. Formación y desarrollo histórico de un señorío prehispánico. Wiesbaden: Franz Steiner.

\section{Robertson, Donald}

1968 The Tulum Murals: The International Style of the Late Post-Classic. Verhandlungen des XXXVIII Internationalen Amerikanisten Kongresses, August 12-18 1968, Stuttgart-Munich 2: 77-88.

Rojas, Gabriel de

1927 Relación de Cholula. Revista Mexicana de estudios históricos 1(6): 155-169. 
Rounds, J.

1977 The Role of the Tecuhtli in Ancient Aztec Society. Ethnohistory. Vol.24 (4) pp. 343-361.

1979 Lineage, Class, and Power in the Aztec State. American Ethnologist Vol. 6(1) pp. 73- 86.

1982 Dynastic Succession and the Centralization of Power in Tenochtitlan. In: The Inca and Aztec States 1400-1800. Edited by George A. Collier, Renato I. Rosaldo, and John D. Wirth. pp. 63-89. New York: Academic Press.

Sahagún, Bernardino de

1950-1982 Florentine Codex: General History of the Things of New Spain. Translated from the Aztec into English by Arthur J. O. Anderson and Charles E. Dibble. Santa Fe: The School for American Research and the University of Utah.

Sahlins, Marshall

1958 Social Stratification in Polynesia. Seattle: University of Washington Press.

1983 Other Times, Other Customs: The Anthropology of History. American Anthropologist 85(3): pp. 517-544.

Sanders, William T., Jeffrey R. Parsons and Robert S. Santley

1979 The Basin of Mexico: Ecological Processes in the Evolution of a Civilization.

New York: Academic Press.

Schele, Linda, and Mary Miller

1986 The Blood of Kings: Dynasty and Ritual in Maya Art. Fort Worth: Kimbell Art Museum.

Schultes, Richard Evans and Albert Hoffman

1979 Plants of the Gods: Their Sacred, Healing and Hallucinogenic Powers. New York: McGraw-Hill.

Seler, Eduard

1904a Deities and Religious Conceptions of the Zapotecs. In: Mexican and Central American Antiquities, Calender Systems, and History. Washington D.C.: Bureau of Ethnology Smithsonian Institution Bulletin 28: pp. 284-305. 
1904b Zapotec Priesthood and Ceremonials. In: Mexican and Central American Antiquities, Calender Systems, and History. Washington D.C.: Bureau of American Ethnology Smithsonian Institution Bulletin 28: pp. 275-283.

1939 Gesammelte Abhandlungen zur Amerikanischen Sprach- und Alterthumskunde. 5 Vols. Unpublished English Translations of German Papers in the Above Work Made Under the Supervision of Charles W. Bowditch. Edited by J. Eric Thompson and Francis B. Richardson.

1960 Gesammelte Abhandlungen zur Amerikanischen Sprach- und Altertumskunde. 5 Vols. Graz: Akademische Druck.

1963 Comentarios al Códice Borgia. 2 Volumes. México: Fondo de Cultura Económica.

Service, Elman R.

1962 Primitive Social Organization. New York: Random House.

Smith, M.E.

1963 The Codex Colombino: A Document of the South Coast of Oaxaca. Tlalocan Vol. IV (3) 276-288.

1973a Picture Writing from Ancient Southern Mexico: Mixtec Place Signs and Maps. Norman: University of Oklahoma Press.

1973b The Relationship between Mixtec Manuscript Painting and the Mixtec Language: A Study of Some Personal Names in Codices Muro and Sánchez Solís. In: Dumbarton Oaks Conference on Mesoamerican Writing Systems. pp. 47-98. Edited by Elizabeth Benson. Washington, D.C.: Dumbarton Oaks.

1983a Codex Selden: A Manuscript from the Valley of Nochixtlan? In: The Cloud People: Divergent Evolution of the Zapotec and Mixtec Civilizations. Edited by Kent Flannery and Joyce Marcus. pp. 248-255. New York: Academic Press.

1983b Regional Points of View in the Mixtec Codices. In: The Cloud People: Divergent Evolution of the Zapotec and Mixtec Civilizations. Edited by Kent Flannery and Joyce Marcus. pp. 260-266. New York: Academic Press.

Spinden, Herbert J.

1935 Indian Manuscripts of Ancient Southern Mexico. 1933 Annual Report of the Smithsonian Institution, pp. 429-451. Washington D.C: Smithsonian Institution. 
Spores, Ronald

1967 The Mixtec Kings and Their People. Norman: University of Oklahoma Press.

1972 An Archaeological Settlement Survey of the Nochixtlan Valley, Oaxaca. Nashville: Vanderbilt University Publications in Anthropology, No. 1.

1974 Marital Alliance in the Political Integration of Mixtec Kingdoms. American Anthropologist 76: pp. 297-311.

1983 The Origin and Evolution of the Mixtec System of Social Stratification. In: The Cloud People: Divergent Evolution of the Zapotec and Mixtec Civilizations. pp. 227238. Edited by Kent Flannery and Joyce Marcus. New York: Academic Press.

1984 The Mixtecs in Ancient and Colonial Times. Norman: University of Oklahoma Press.

Spranz, Bodo

1973 Los Dioses en los códices mexicanos de grupo Borgia. México: Fondo de Cultura Económica.

Stark Cambell, Sara; Andrea Johnson Peterson, Filiberto Lorenzo Cruz, Catalina López de García, and Daniel Fidencio García Alavez

1986 Diccionario mixteco de San Juan Colorado. México: Instituto Lingüístico de Verano.

Stenzel, Werner

1972 The Sacred Bundles in Mesoamerican Religion. In: Actas del XXXVIII Congreso Internacional de Americanistas. II pp. 347-352. Stuttgart.

Stephens, John L.

1949 Incidents of Travel in Central America, Chiapas, and Yucatan. 2 Vols. New Brunswick: Rutgers University Press.

Taube, Karl

1983 The Teotihuacan Spider Woman. Journal of Latin American Lore. Vol. 9(2) pp. 107-189. 
Topsey, Harriot Wentward

n.d. The Coixtlahuaca Group of Mexican Manuscripts: An Examination. 1985 University of Calgary unpublished Master's thesis. Manuscript in author's possession.

Torquemada Juan de

1943 Monarquía Indiana. Volume I. México: Editorial Salvador Chavez Hayhoe.

Townsend, Richard

1979 State and Cosmos in the Art of Tenochtitlan. Studies in Pre-Columbian Art and Archaeology. No. 20. Washington, D.C.: Dumbarton Oaks.

Troike, Nancy Patterson

n.d.a. The History of the Codex Zouche since 1854. Paper presented at the XXXIX Congreso Internacional de Americanistes. Lima August 2-9, 1970. Manuscript in author's possession.

n.d.b. The Codex Colombino-Becker. Unpublished Ph.D. dissertation. University of London, 1974. Manuscript in author's possession.

1978 Fundamental Changes in the Interpretations of the Mixtec Codices. American Antiquity 43 (4): 553-568.

1982 The Interpretation of Postures and Gestures in the Mixtec Codices. In: Dumbarton Oaks Conference on the Art and Iconography of Late Post-Classic Central Mexico. pp. 175-206. Edited by Elizabeth Boone. Washington, D.C.: Dumbarton Oaks.

Vaillant, George

1962 The Aztecs of Mexico. Second Edition. Revised by Suzannah B. Vaillant. Garden City: Doubleday.

Velázquez, Primo Feliciano

1945 Codice Chimalpopoca: Anales de Cuahtitlan y Leyenda de los Soles. México: Imprenta Universitaria.

Wasson, R. Gordon

1980 The Wonderous Mushroom: Mycolatry in Mesoamerica. New York: McGraw-Hill Book Company. 
Wasson, R. Gordon; George Cowan, Florence Cowan, and Willard Rhodes

1974 Maria Sabina and her Mazatec Mushroom Velada. New York: Harcourt Brace Jovanovich.

Webster, David

1976 On Theocracies. American Anthropologist. Vol.78(4) pp. 812-828.

Willey, Gordon

1985 Ancient Chinese-New World and Near Eastern Ideological Traditions: Some Observations. Symbols: Spring Issue 1985. Harvard University Peabody Museum and the Department of Anthropology.

Williams, Edwina

n.d. Obsidian Acquisition, Production, and Distribution in the Tilantongo and Jaltepec Regions of the Mixteca Alta: Specialized Craft Production in the Postclassic. Paper presented at the 87th Annual meeting of the American Anthropological Association. Phoenix.

Winter, Marcus

1989 Oaxaca: The Archaeological Record. Mexico: Minutiae Mexicana.

Wissler, Clark

1912 Ceremonial Bundles of the Blackfeet Indians. American Museum of Natural History, Anthropological Papers 7(2): 65-289.

1920 The Sacred Bundles of the Pawnee. Natural History 20: 569-571.

Yoneda, Keiko

1981 Los Mapas de Cuauhtinchan y la historia cartográfica prehispánica. México: Archivo General de la Nación. 